
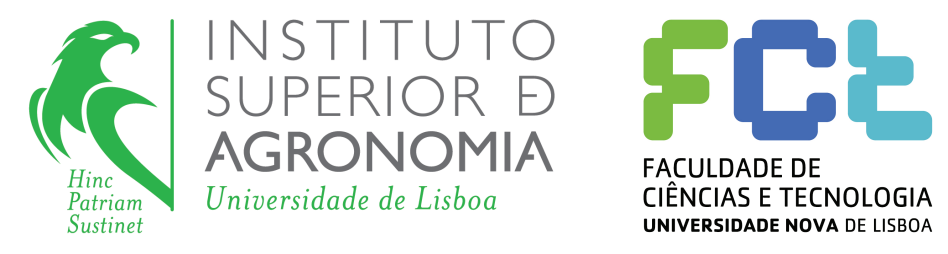

\title{
DESIGNING FOR THE SENSES THROUGH FOOD DESIGN AND PSYCHOPHYSIOLOGY
}

\author{
Rui Manuel Nunes Mota
}

Dissertação para a obtenção do Grau de Mestre em

Ciências Gastronómicas

Orientador (es): $\quad$ Prof. $^{\text {a }}$ Doutora Maria Paulina Estorninho Neves da Mata (FCT/UNL) Especialista Ricardo Manuel Carrilho Bonacho (FA/UL)

Presidente: Doutora Catarina Paula Guerra Geoffroy Prista, Professora Auxiliar do Instituto Superior de Agronomia da Universidade de Lisboa.

Vogais: $\quad$ Doutor Ricardo Manuel Carrilho Bonacho, Professor Adjunto Convidado da Escola Superior de Hotelaria e Turismo do Estoril, orientador.

Licenciada Héloïse Vilaseca, Diretora de I+R do(a) El Celler de Can Roca, na qualidade de especialista.

Lisboa, 2018

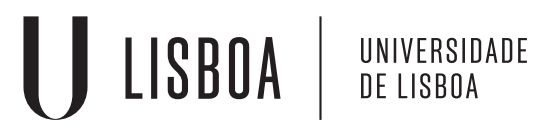





\section{ACKNOWLEDGMENTS}

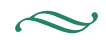

This work would not have been possible if it were not for a very special group of people who helped me all the way through, some directly in the dissertation itself and others by supportive means.

Firstly, I would like to express my sincere gratitude to my supervisor Professor Paulina Mata, one of the founders of the MSc in Gastronomic Sciences, for her persistent guidance, extreme critical opinion and constant availability in critical times. It is indeed a huge privilege being her student. I could not have imagined having a better supervior and mentor for my MSc dissertation project.

To all the Staff of El Celler de Can Roca that received and accepted me in the best possible way. In particular to Héloïse Vilaseca, director of La Masia (I\&R), that improved my working methods, through her passionate way of sharing her thoughts regarding the application of science in the kitchenand by providing learning opportunities, critical opinions and constant availability even in critical times. To Chefs Joan, Jordi and Josep Rocca for allowing everything to be possible. To Joana Pedret for an important and essential support. To Gemma Barceló, Bernat Guixer, Eshter Massats and Joan Carbó for giving me the privilege of working aside them. To Elena Portillo for being the purest heart I found in Catalonia and for teaching me so much about glassware productions and recycling. Without their precious support it would not have been possible to conduct this research.

To Professor Ricardo Bonacho who was the first to show me how Design can be applied on Cooking. For his supervision and guidance, and also for the academic and professional opportunities. Also, for the hard questions which encourage me to widen my research from various perspectives.

To all the Staff of Vista Alegre Atlantis for receiving me and providing all the needed conditions. In special to Richard Williams for being the best plateware designer that I know, it was a privilege working aside him. To Alda Tomás for the coordination and instructions on VAA design product process. To Madalena Esteves and Abílio Aires for all the technical support on hand modulation of ceramics. To Catarina Alvarez and Mariana Catarino for inviting me to embark on this journey and for all the logistics. To engineers Carla Castilho and Sousa Bastos for all the production process supervision and problem solving.

To Pastry Chef Fabian Nguyen and other Chefs at Ritz Four Seasons for receiving me to evaluate my dessert and for providing all the resources and availability for the realization of the Focus Group.

To Humberto Ribeiro and all of the staff at J.Roma, Lda for allowing me to use its thermal cameras.

To ORGANII and in particular to Ricardo Spencer to provide all the bio organic essential oils needed and for developing some different ones as asked.

To Professor Ana Cristina Figueiredo from FCUL, for all her knowledge and input about essential oils and plant extractions. Also, to Professor Ana Amorim from FCUL, for clearing up some scientific biological details about seaweeds.

To Paulo Gomes, CEO of Red Frog Bar, for providing some machinery from his laboratory and for discussing some ideas with me.

To Microgreens, in particular to Tomás Lencastre and Vasco Palha for providing all the quality herbs and flowers for cooking and plating. 
To Professor Anabela Raymundo, Professor Suzana Ferreira Dias, Professor Isabel Sousa for always being available to clarify eventual doubts about vegetal proteins and sensory analysis.

To Professor Catarina Prista for all the academic and emotional support and for her passionate way of teaching, was a privilege being her student.

To Illustrator Traci Page Morris, a Noma Restaurant artist, for her stunning work and for giving me the privileged of having such exclusive water colour masterpieces on my thesis. Also, to Illustrator Natalia Maksakova, to Illustrator Ea Fable and to Illustrator Sandra Nguyen for all the water colour painting.

To Chef Sang Hoon Degeimbre and all his staff for sharing their culinary knowledge and for including me as part of the team. In particular to Claire Habchi, Olivier De Vriendt and Kevin Perlot for their guidance and closest team spirit. Also, to Benoît Blairvacq and his gardening staff team for showing me how to understand nature and properly harvest.

To Professor Charles Spence for his inspiring work and for peer reviewing my paper.

To Professor Marta Vacas de Carvalho for her guidance on the data statistics analysis and interpretation.

To my especial and very supportive friends Bárbara Talharim, Ariana Fernandes, Daniela Baptista, Carina Duarte, Maria Genoveva, Teresa Pinto, among so many others that somehow interfere with this adventure, for their insightful comments and encouragement.

To Graphics Designer Mariana Duarte for helping on the paging layout of this thesis.

To my family who invested a lot, have always been supportive and who never questioned the path I chose.

To all who made it possible,

Thank You. 


\title{
ABSTRACT
}

$\infty$

Nowadays there is a whole new approach to food and cooking. A meal involves a complex composition of textures, colours, shapes, tastes, aromas, flavours and sounds, resulting in gastronomical pieces which cause various sensations and emotions to consumers. Chefs should use knowledge from the areas of psychology, design, science, etc., and even work with professionals from these areas, as this interdisciplinary holistic approach, allows to achieve better results and improve sensory characteristics.

The research and work presented on this dissertation consists on the development of a menu inspired by a forest and composed by five dishes, each one focused in stimulating a particular human sense - Sight, Smell, Hearing, Taste and Touch. Each dish involves different contents and techniques and is based in different hypothesis and research results in the literature.

Dishes were created based on design rules, tools and methodologies. The Double Diamond design process was applied in the creative design process.

For the Sight dish optical illusion created by using a floating plate and UV blacklight was used as a tool to trigger emotions and influence taster's perception.

For the Smell dish the impact of containers with different shapes and characteristics on the perception of of aroma and flavour was evaluated. This study took place at La Masia (I+R) of Restaurant EI Celler de Can Roca. The results were applied by Vista Alegre Atlantis $®$ on the design and conception of two porcelain pieces to be included in the Chefs' Collection.

The third dish, focused on the Hearing sense, consists in an edible representation of a forest having an audio component. Previous knowledge on the influence of sound in the perception of food, was used to introduce a sonic seasoning in the main course of this menu.

Furthermore, a pre-dessert related to the Taste sense applies knowledge about the efficiency of Palate Cleanser.

Finally, for Touch, a monochromatic dessert was designed based on knowledge about cross modal correspondences. A Focus Group analysis was done by a panel composed by Ritz Four Season's Chefs.

In order to improve knowledge and skills, two internships periods were done at the Belgium two Michelin stars restaurant L'Air du Temps and at La Masia (I+R) of Restaurant El Celler de Can Roca (three Michelin stars).

\author{
KEYWORDS: \\ Food-Design; \\ Psychophysiology; \\ Gastrophysics; \\ Sensory Perception; \\ Ergonomics
}




\section{SÚMÁRIO}

$\propto$

Atualmente existe toda uma nova abordagem aos alimentos e à cozinha. Uma refeição envolve uma complexa composição de texturas, cores, formas, sabores, aromas e sons, resultando em encenações gastronómicas que causam várias sensações e emoções aos consumidores. Os Chefes devem utilizar conhecimento das áreas de psicologia, design, ciências, etc., e inclusive colaborar com profissionais destas áreas, dado que uma abordagem holística interdisciplinar permite alcançar melhores resultados e melhorar as características sensoriais.

A pesquisa e trabalho de investigação apresentado nesta dissertação consiste no desenvolvimento de um menu inspirado numa floresta e composto por cinco pratos, cada um focado em estimular um sentido humano em particular - Visão, Cheiro, Audição, Gosto, Tato. Cada prato envolve diferentes conteúdos e técnicas e é baseado em diferentes hipóteses e pesquisas de investigação.

Os pratos foram criados tomando em consideração regras, ferramentas e metodologias de design. $O$ processo de design Double Diamond foi aplicado no processo criativo de design.

Para o prato da Visão foi criada uma ilusão ótica através de um prato flutuante e luz UV como ferramentas para despontar emoções e influenciar a perceção do provador.

Para o prato do Cheiro foi avaliado o impacto de recipientes com diferentes formas e características na perceção aromática. Este estudo ocorreu em La Masia(I+R) do Restaurante El Celler de Can Roca. Os resultados foram aplicados pela Vista Alegre Atlantis $₫$ no design e conceção de duas peças em porcelana a serem incluídas na sua gama Chefs' Collection.

O terceiro prato, focado no sentido da Audição, consiste numa representação comestível de uma floresta utilizando uma componente áudio. Estudos prévios sobre a influência do som na perceção alimentar foram usados para introduzir um tempero sónico ao prato principal deste menu.

No seguimento, a pré-sobremesa, relacionada com o Gosto, debruça-se sobre a eficiência de um limpa-palato.

Finalmente, para o Tato, uma sobremesa monocromática foi projetada com base nas correspondências modais cruzadas. Confrontada com uma análise sensorial executada em grupo de foco por um painel composto pelos Chefes do Ritz Four Season's.

Com o intuito de desenvolvimento de conhecimento e técnicas, dois períodos de estágio foram realizados: no restaurante belga, premiado com duas estrelas Michelin, L'Air du Temps e na La Masia (I+D do restaurante El Celler de Can Roca (três estrelas Michelin).

\footnotetext{
Palavras-chaVe:

Design de Alimentos;

Psicofisiologia;

Gastrofísica;

Perceção Sensorial;

Ergonomia;
} 


\section{RESUMO}

$\sim$

Hoje em dia, há uma abordagem totalmente nova à comida e à culinária. Uma refeição envolve uma composição complexa de texturas, cores, formas, sabores, aromas, sabores e sons, resultando em peças gastronómicas que causam várias sensações e emoções aos consumidores. Os chefs devem utilizar os conhecimentos das áreas de psicologia, design, ciências, etc., e até trabalhar com profissionais dessas áreas, já que essa abordagem holística interdisciplinar, permite alcançar melhores resultados e melhorar as características sensoriais. Tudo o que se come é profundamente influenciado pelo que se vê, sente, cheira ou ouve. As correspondências ou associações modais cruzadas estão também associadas a estímulos sensoriais completos e sinérgicos que definem o subconsciente, emoções, comportamentos e aprendizagens, imagens mentais e cultura de cada indivíduo.

Ao longo do mestrado em Ciências Gastronómicas, um estágio extracurricular no Restaurante L'Air du Temps (duas estrelas Michelin) na Bélgica e um estágio em trabalho de investigação na La Masia $(I+R)$ do Restaurante El Celler de Can Roca (três estrelas Michelin) na Catalunha, contribuíram para um incremento de conhecimentos e competências aplicados aos trabalhos, estudos e pesquisas desenvolvidas para esta dissertação de mestrado.

O trabalho desenvolvido consistiu na conceção de um menu, cujo conceito base é a floresta, e o desenvolvimento envolve uma simbiose do Design com técnicas de cozinha atuais e de vanguarda. Houve ainda uma exploração de outras áreas, como design de produto na produção de peças de porcelana. Dada diversidade de características deste trabalho foi necessário recorrer a uma vasta gama de técnicas para além das referidas, como a estatística, psicologia da cor, termografia e magnetismo.

Trata-se de um trabalho metodológico-científico de investigação, que envolveu o desenvolvimento, e nalguns casos avaliação, dos cinco pratos que constituem um menu. Cada um deles pretende estimular em particular um dos cinco sentidos humanos - Visão, Cheiro, Audição, Gosto e Tato. Cada prato envolve diferentes conteúdos, técnicas e hipóteses de trabalho baseadas em resultados de investigação publicados. Todos os exercícios projetuais adotaram um modelo de processo criativo em Design [1].

O conceito subjacente ao menu é inspirada nos bosques e decorre ao longo das diferentes fases do dia, cada prato esta contextualizado em cada uma dessas fases.

O primeiro momento, Mooning Walk, começa na noite escura com utilização de cores como o azul escuro, castanho, preto, cinzento e fluorescência. Este prato que tem uma composição visual forte está associado ao sentido da visão. Um prato flutuante e luz negra foram aqui utilizados para criar ilusão ótica, movimento, tridimensionalidade e efeitos fluorescentes que representam os pirilampos, mochos, ramos, lua, constelações, etc. Um dos principais objetivos consiste em representar e conferir mistério, escuridão, surpresas e todos os outros encantos que uma floresta tem durante a noite. A luz do luar e o nascer do sol são ilustradas pelo tipo de iluminação que o prato recebe, o que resulta assim numa dupla leitura e interpretação.

O prato seguinte, Drinkable Smoke, focado no sentido do cheiro está inspirado nas manhãs ensolaradas e na flora de uma floresta. Composto por tons claros e diferentes aromas terrosos. Óleo essencial de gengibre e de mandarina verde assim como ervas aromáticas, flores e especiarias foram aqui aplicados para enaltecer as características aromáticas. Carvão de pinho foi usado no processo de confeção e fumagem. $O$ efeito da forma do recipiente em que um prato é servido na perceção de aroma e gosto foi 
avaliada tendo-se verificado que há uma influência significativa, particularmente na perceção do cheiro e do aroma. O estudo envolveu testes de análise sensorial com 33 empregados do restaurante El Celler de Can Roca, resultados obtidos foram sujeitos a uma análise estatística recorrendo aos programas IBM SPSS Statistic grad Pack 24 e XLstatics. A utilização de uma máquina fotográfica Flir termal T360, permitiu ainda obter registo térmico que foi relacionado com os resultados obtidos. Os resultados finais foram aplicados na conceção de duas peças de porcelana na Vista Alegre ${ }^{\circledR}$ a incluir na gama de Chefs' Collection. Os resultados foram apresentados na $1^{\circ}$ Conferência Internacional em Food Design and Food Studies: Experiencing Food and Designing Dialogues [2].

O prato principal focado na Audição aporta uma componente sonora: uma melodia de sons de floresta, água a correr, chilrear de pássaros, vento, brisa e ramos a partir. Relembra uma floresta, com flores, ervas, ramos de $100 \%$ chocolate preto, um rio, orvalho e humidade de uma floresta, mini vegetais e trufa preta.

O seguinte prato do menu, Greenly Fresh, é focado no sentido do Gosto e é um limpa palato em que foram aplicados os conhecimentos descritos sobre como aumentar a eficiência deste tipo de preparações. Os sentidos, especialmente o paladar, tornam-se facilmente saturados e é importante aliviar e acorda-los de novo. Dado o conceito base, relacionado com os bosques, este prato representa a vegetação verde e os sabores ácidos. No design deste prato a psicologia da cor e a correspondência modal cruzada aforam consideradas.

O último prato do menu, Beet Grains, é focado no sentido do Tato e foi concebido considerando as correspondências intermodais ou outros efeitos no nosso sistema somatossensorial. O elemento base é a beterraba, e representa o pôr do sol na floresta com cores como o roxo e vermelhos naturais conferidos pelas betalaínas. Cada um dos 15 elementos que a compõem possuem uma textura diferente. Entre temperaturas, humidade, cremosidade, crocância, mastigabilidade e fluidez, este prato é uma viagem completa em torno de todas as texturas que poderiam existir numa floresta. Foi realizada uma sessão de avaliação externa, através de um grupo de foco com 6 Chefs no Ritz Four Seasons em Lisboa.

O trabalho desenvolvido envolveu um extenso trabalho de conceção, design, testes, confeção, preparo e desenvolvimento destes pratos, o resultado é apresentado ao longo desta dissertação, bem como todo o processo de investigação registado em paralelo à componente prática.

PALAVRAS-ChAVE:

Design de Alimentos;

Psicofisiologia;

Gastrofísica;

Perceção Sensorial;

Ergonomia; 


\section{CONTENTS}

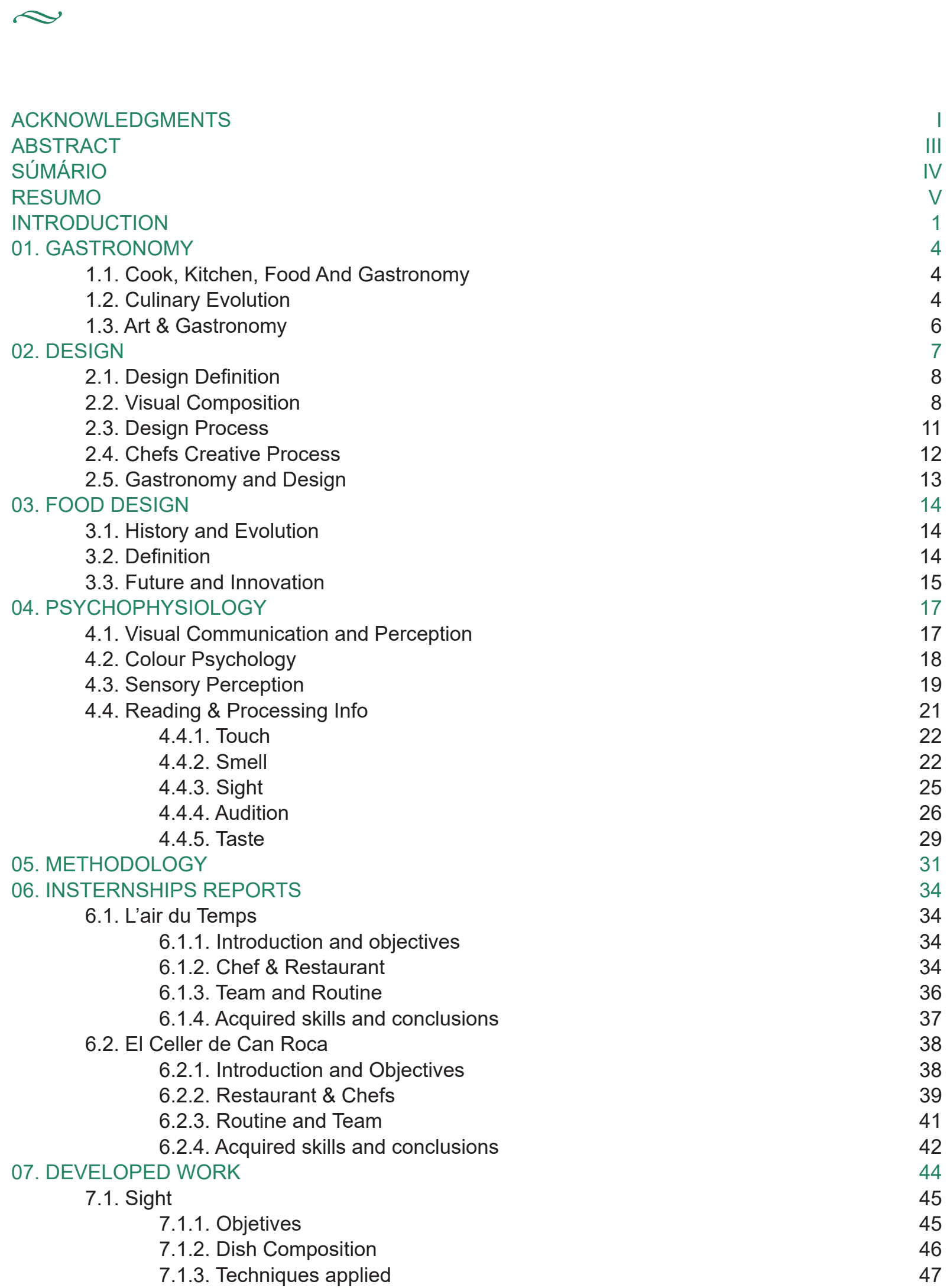


$\begin{array}{ll}\text { 7.1.4. Plate Design } & 49\end{array}$

7.1.5. Results, evaluation and discussion $\quad 52$

7.1.6. Conclusion $\quad 54$

7.2. Smell 55

7.2.1. Objectives $\quad 55$

7.2.2. Dish Composition $\quad 55$

$\begin{array}{ll}\text { 7.2.3. Techniques applied } & 57\end{array}$

7.2.4. Plate Design $\quad 58$

$\begin{array}{ll}\text { 7.2.5. Sensory Evaluation } & 62\end{array}$

7.2.6. Results 63

$\begin{array}{ll}\text { 7.2.7. Discussion } & 65\end{array}$

$\begin{array}{ll}\text { 7.2.8. Conclusion } & 67\end{array}$

7.3. Hearing 68

$\begin{array}{ll}\text { 7.3.1. Objectives } & 68\end{array}$

$\begin{array}{ll}\text { 7.3.2. Dish composition } & 69\end{array}$

$\begin{array}{ll}\text { 7.3.3. Techniques applied } & 71\end{array}$

$\begin{array}{ll}\text { 7.3.4. Plate Design } & 73\end{array}$

$\begin{array}{ll}\text { 7.3.5. Results and discussion } & 73\end{array}$

$\begin{array}{ll}\text { 7.3.6. Conclusion } & 75\end{array}$

$\begin{array}{ll}\text { 7.4. Taste } & 76\end{array}$

$\begin{array}{ll}\text { 7.4.1. Objectives } & 76\end{array}$

$\begin{array}{ll}\text { 7.4.2. Dish Composition } & 77\end{array}$

$\begin{array}{ll}\text { 7.4.3. Techniques Applied } & 77\end{array}$

$\begin{array}{ll}\text { 7.4.4. Plate Design } & 80\end{array}$

7.4.5. Results, evaluation, discussion and conclusions $\quad 81$

7.5. Touch 82

7.5.1. Objetives $\quad 82$

7.5.2. Dish Composition $\quad 82$

$\begin{array}{ll}\text { 7.5.3. Techniques applied } & 84\end{array}$

$\begin{array}{lr}\text { 7.5.4. Plate Design } & 88\end{array}$

$\begin{array}{lr}\text { 7.5.5. Results } & 89\end{array}$

7.5.6. Focus Group for evaluation $\quad 89$

$\begin{array}{ll}\text { 7.5.7. Discussion and Conclusion } & 91\end{array}$

08. CONCLUSION 94

09.BIBLIOGRAPHY $\quad 97$

10. ATTACHMENTS 104

10.1. RECIPE - MOONING WALK 104

10.2. RECIPE - DRINKABLE SMOKE 106

10.3. RECIPE - SOUNDS OF THE FOREST 107

10.4. RECIPE - GREENLY FRESH 110

10.5. RECIPE - BEET GRAINS 111

10.6. FORMULARIO DE ANÁLISIS SENSORIAL 116

$\begin{array}{ll}\text { 10.7. PAPPER SUBMITED CRC LAYOUT } & 117\end{array}$

10.8. 3D PROTOTYPES AND TECHNICAL DRAWS VAA 118 


\section{FIGURES INDEX}

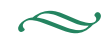

Figure 1. Double Diamon design process, Brithish Council (2005)

FIGURE 2. Model development process and innovation of michelin star chefs - adapted from Ottenbacher and Harrington (2007: 444)

Figure 3. Somatosensory axis of the nervous system, Guyton and Hall (2006)

FIGURE 4. Organization of the olfactory membrane and olfactory bulb, and connections to the olfactory tract, Guyton and Hall (2006)

FIGURE 5. Neural connections of the olfactory system, Guyton and Hall (2006)

FIGURE 6. Photoreceptor cells: rods and cones, Lopes (2013)

FIGURE 7. The external, middle and inner ears, Guyton and Hall (2006)

FIGURE 9. 'Bouba' and 'Kiki' experiment, Hanson-Vaux, Crisinel and Spence, (2013)

FIGURE 10. Restaurant front door (left); Gardening House (right); Rui Mota, 2016

FIGURE 11. Restaurant back view with garden, Stéphanie Biteau, 2013

Figure 12. Some of Sang-Hoog's dishes, Stéphanie Biteau, $2014 \quad 35$

Figure 13. Chefs on the Pass, Stéphanie Biteau, 2014

Figure 14. Staff, Stéphanie Biteau, $2016 \quad 37$

Figure 15. El Celler de Can Roca Kitchen, $2017 \quad 39$

Figure 16. El Celler de Can Roca The World Dish, Juan Pujol-Creus, $2016 \quad 40$

Figure 17. Some of El Celler de Can Roca Savoury dishes, David Ruano and Paco Amate, 2014

Figure 18. Some of El Celler de Can Roca pastry dishes, Juan Pujol-Creus, 2016

Figure 19. Formation with Chef Joan Roca at La Masía, El Celler de Can Roca, 2017

Figure 20. La Masía from El Celler de Can Roca inside and outside, David Ruano and Paco Amate, 201742

FiguRE 21. Ferran Adriá Presentation "Sapiens, Understand to Create", Rui Mota, 201743

FIgURE 22. Presentation about Food Design, Rui Mota, $2017 \quad 43$

$\begin{array}{ll}\text { FIGURE 23. Mooning walk, top view under sunlight. } & 47\end{array}$

$\begin{array}{ll}\text { FIGURE 24. Mooning walk, under blacklight front view, } 2018 & 48\end{array}$

FIGURE 25. Riboflavin structure, Johnson, $1955 \quad 48$

FIGURE 26. Magnetic levitation, maglev or magnetic suspension, Thompson, 200048

$\begin{array}{ll}\text { Figure 27. Ergonomy drafts, } 2018 & 49\end{array}$

FIGURE 28. Mooning walk plating 1, under blacklight (left) under sunlight (right), 2018

FIGURE 29. Mooning walk plating 3, under blacklight (left) under sunlight (right), 2018

FIGURE 30. Mooning walk plating 2, under blacklight (right) under sunlight (left), 2018

FIGURE 31. Mooning walk plating 2, under blacklight (left) under sunlight (right), 2018

FiguRE 32. Drinkable Smoke in bottle dish, Vista Alegre, 2018.

FIGURE 33. Drinkable Smoke in bottle dish, Vista Alegre, $2018 \quad 56$

FIGURE 34. Preparing the celeriac purée, Joana Pedret, $2018 \quad 58$

FIGURE 35. Roca Recicla machinery, $2018 \quad 60$

FIGURE 36. Drafts and digital prototypes, Vista Alegre, 2018

FiguRE 37. Modulation process, Vista Alegre, 2018

FIGURE 38. Sensory Analysis, $2018 \quad 63$

FIGURE 39. Mean scores of the perceived intensities of smell by sniffing, and of aroma by tasting using a spoon and drinking a sip.

FiguRE 40. Biplot (axis F1 and F2: 95,39 \%) made as a result of PCA method to evaluate from all the features, which were more associated to each container.

FIGURE 41. Profile spider chart hem in positives counting of the relevant aromatic characteristics for the three containers.

FIGURE 42. Five thermal pictures in sequence using a Flirß, of the bottle dish within 3 minutes difference between each. 
FIGURE 43. Five thermal pictures in sequence using a Flir®, of the glass dish within 3 minutes difference between each.

FIGURE 44. Five thermal pictures in sequence using a Flir®, of the bowl dish within 3 minutes difference between each.

FigURE 45. Three thermal pictures in sequence using a Flir®, of the glass dish of ceramic by Vista Alegre within 10 minutes difference between each.

FIGURE 46. Three thermal pictures in sequence using a Flir®, of the bottle dish of ceramic by Vista Alegre within 10 minutes difference between each.

FIGURE 47. Single thermal pictures using a Flir®, of the three dishes: glass, bottle and bowl (from left to right reading), picture took after 11 minutes after being plated.

FIGURE 48. Single thermal pictures using a Flir®, of both dishes: glass and bottle (from left to right reading), picture took after 30 minutes after being plated.

FIGURE 49. Drinkable Smoke, Ceramic Glass container from Vista Alegre, 201868

Figure 50. Sound of the Sea Dish, Heston Blumenthal, $2008 \quad 69$

FIguRE 51. Sound of the Sea Dish, Heston Blumenthal, $2008 \quad 69$

FIGURE 52. Heston Blumenthal plating Sound of the Sea Dish, $2008 \quad 69$

FIGURE 53. Sounds of the Forest with wireless earphones, 2018

FIGURE 54. Tempering sequence during lipid crystallisation in chocolates, Afoakwa, $2010 \quad 72$

FiguRE 55. Sounds of the Forest, $2018 \quad 73$

FIGURE 56. Sounds of the Forest, $2018 \quad 74$

$\begin{array}{ll}\text { FIGURE 57. Sounds of the Forest draft, } 2018 & 74\end{array}$

$\begin{array}{ll}\text { FIGURE 58. Greenly Fresh dish, numbering elements, } 2018 & 78\end{array}$

FIGURE 59. Pates making, cutting with hand saw, $2018 \quad 79$

$\begin{array}{ll}\text { FIGURE 60. Plates drafts and trials, } 2018 & 79\end{array}$

$\begin{array}{ll}\text { FiguRE 61. Plating Greenly Fresh draw, } 2018 & 80\end{array}$

FIGURE 62. Greenly Fresh dishes, $2018 \quad 80$

FigURE 63. Greenly Fresh dish, $2018 \quad 82$

FIgURE 64. Beet Grains Dish, $2016 \quad 83$

Figure 65. Beet Grains Dish, $2017 \quad 84$

FIGURE 66. Plating Beet Grains Dish, Ritzs Four Seasons Lisbon, 2017

FIGURE 67. Different platings of Beet Grains dish, $2016 \quad 88$

FIguRE 68. Beet Grains dish, Ritzs Four Seasons Lisbon, $2017 \quad 89$

FIGURE 69. Plating Beet Grains Dish, Ritzs Four Seasons Lisbon, 201790

FIgURE 70. Focus groups with Chefs, Ritzs Four Seasons Lisbon, 201790

$\begin{array}{lr}\text { FiguRE 71. Mooning Walk under sunlight, } 2018 & 104\end{array}$

FIGURE 72. Mooning Walk under blacklight, $2018 \quad 105$

FiguRE 74. Sounds of the Forest, $2018 \quad 107$

FiguRE 75. Sounds of the Forest, $2018 \quad 109$

FIGURE 76. Sounds of the Forest, $2018 \quad 109$

FIGURE 77. Greenly Fresh dish, $2018 \quad 110$

FIGURE 78. Greenly Fresh dish, $2018 \quad 110$

FIGURE 79. Beet Grains dish, $2018 \quad 115$

\section{TABLES}

TABLE 1 - Formal and chromatic analysis of the different compositions $\quad 74$

TABLE 2 - List of texturizers and characteristics of its applications 81

TABLE 3 - Drafts and the final glass containers $\quad 84$

TABLE 4 - Hydrocolloids and Texturizers applied at Beet Grains recipe 113 


\section{INTRODUCTION}

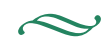

The work described in this dissertation encompasses the conception and analysis of a sensory menu of five dishes which was designed based on previous knowledge described in the literature about the correlations between food, design and psychophysiology and how to enhance tasters overall sensory experience.

With the evolution of society, humanity moved from feeding themselves from the point of view of need and nutrition, to the playful attitude of enjoying delicacies and the pleasure provided by them. This tendency has generated a "revolution" in the relation of some consumers to food. Also a few decades ago, mankind used their hands as cutlery, and later occurred the creation and development of utensils such as forks, knives, spoons, among others. Initially just with utilitarian characteristics, but through design they started to acquire new functional and aesthetical characteristics. Food design emerged as any 'action' that can improve the relationship with food individually or collectively in diverse ways and instances, including the design of food products, materials, experiences, practices, technology, environments and systems." [4], [5].

The scientific method is characterized by careful observation, formation of hypotheses and tests, controlled experimentation, scientific objectivity, and experimental reproducibility. Cooking was not always seen as related to science, however, the importance of using the method to understand the properties of food was already recognized from the eighteenth century, by Lavoisier and half a century later, for example, by Brillat-Savarin. The situation started changing in the twenty century due to scientists as Nicolas Kurti, Hervé This, Harold McGee our Peter Barham [6]. Nicolas Kurti said in 1969 "Is it not quite amazing that today we know more about the temperature distribution in the atmosphere of the planet Venus than that in the centre of our soufflé?" and this can be considered a turning point in the way cooking is seen [7].

Contrary to what happened in previous centuries, where culinary development was mainly empirical, nowadays, with the advent of molecular gastronomy, the approach to the development of culinary processes is no longer exclusively empirical but is related to scientific knowledge. The logical scientific explanation of its mechanism allowed rational and more sustained development.

This approach enabled the emergence of a highly creative branch of gastronomy, encouraging gastronomic innovation through the development of new products, equipment and sensory attributes, frequently by multidisciplinary teams involving people from different areas of knowledge.

The introduction of new ingredients, techniques and equipment in the kitchen, associated with a deeper knowledge, allowed many cooks to subvert the structure of menus, modify food textures, create unusual dishes, making the meal a playful and intellectual experience. Thus, concepts like "creativity" or "innovation" are leaders in the current gastronomy scene. HAROLD MCGEE, (2004), argues that technology should not be used as an end because it is new, but as a mean for the purpose of obtaining an excellent result.

Professor Charles Spence, a psychologist, is the head of the Crossmodal Research Laboratory, at the University of Oxford has been focusing his studies on food perception, specially psychophysiology, or as he calls it gastrophysics. His work suggests that multisensory perception might be the key to comprehend how food is perceived [8]. Studying how the brain works and manages this multisensory perception is important to understand how to control individual sensory worlds. Other influences related to the perception of food and the world are more abstract, feelings and emotion are good examples, 
and understanding how they are generated and what is its influence in food perception is important [9].

In the XIX century, Brillat-Savarin wrote in his book The Physiology of Taste: "Tell me what you eat and I will tell you what you are", from what science has discovered this sentence is true in ways which he could never have imagined [10].

We eat with our eyes, ears, nose, memory, imagination and our gut. Every human being has a relationship with food, some of it positive, some of it negative, but ultimately, it's all about emotion and feeling [8]. The five senses are primarily associated with the objectives of designing a new product, whether edible or not. The senses have a language that frequently translates an experience that is engraved in our memory giving us desire. The smell and vision convey the immediate perceptions, smelling the food is the first thing that is done before putting it in the mouth, is the aroma that provides the passport for the next step. The vision allows a visual reading in an involuntary and very complete way. The mouth-watering is a positive response to a good visual perception. Nonetheless it is the mouth that allows us to completely interpret the flavour of food, combining the perception of texture, aroma and taste. Aroma is associated with the stimuli by the volatile compounds through the retro nasal veins and the taste itself is read by the taste buds, these are responsible for the identification of sweet, bitter, salty, acid and umami.

The pleasure we get from food depends, far more than we could possibly imagine, on our subjectivity, on our memories, associations and emotions. Gastrophysics builds on the strengths of a number of disciplines, including experimental psychology, cognitive neuroscience, sensory science, neurogastronomy, marketing, design and behavioral economics, each subject contributing a part of the story with specific techniques designed to answer particular questions. This recent field of research can be defined as the scientific study of those factors that influence our multisensory experience while tasting food and drink [8].

StUMmereR (2013) says that taste is individual, situational and culturally acquired, there are no two identical tastes between continents, for example the Pringles brand has more than 100 different types around the world with seasonings, intensities and aromas that differ from country to country. Taste is a cultural product, a matter of belonging, food design also varies from civilization to civilization, it is the history that builds us, the whole culture, the whole tradition, the whole identity is a result of history, all phenomena of exchange, of crosses, of contamination, generates different cultures, mankind, merchandise, techniques, tastes, from one side to the other of the world, thanks to globalization the Earth is now a multicultural planet [11].

In this context, this work starts aiming not only to understand and apply knowledge about the multisensory phenomena experiences while eating but also to have the possibility of training on job in an environment of professional cuisine where food science is part of the food production system.

In fact, there was also interest on applying and consolidating knowledge gathered from the Gastronomical Sciences master's degree, as well as learning on job with two recognized restaurants, the L'Air du Temps and El Celler de Can Roca which are known for bringing the science into the kitchen.

The work presented on this dissertation is the result of 2 years of research where the main objective was to understand sensory perception through a transdisciplinarity approach in order to reach "The Perfect Meal". The cinematic menu developed is inspired on the woods and runs throughout the different phases of the day. As amuse bouche dish - Mooning Walk, as starter - Drinkable Smoke, as main course - Sound of the Forest, as pre dessert - Greenly Fresh and finally dessert - Beet Grains. Each dish is associated with a complex setting of elements, plateware and ergonomics, from floating plates in leaf shape, monochromatic visual compositions of elements, optical illusions, edible forest that has an audio component associated reproducing forest sounds. Food itself is also inspired on forest, from animals to herbs and flowers, for instance using ingredients as wild pigeon, celeriac, coconut, rabbit, black truffle, mushrooms, vegetables, green tea and beetroot.

Therefore, the following dissertation is divided into four main chapters, the first is a deep literature review regarding design, food design and psychophysiology. Related to design, its definition, processes, 
elements, techniques, visual composition, chefs creative process and relation between gastronomy and design are described. For food design its evolution, definition and future are exposed. Finally, for psychophysiology, how reading and processing info of sensorial perception works, as well as the physiology description of each sense and its crossmodal correspondence. The purpose of this chapter was to understand, on the one hand, the whole approach to design as a discipline, then what food design consists of and how it relates to food production. On the other hand, in psychophysiology, the aim was to expose how we perceive and interpret each of our senses and how they are influenced by the various inputs already studied and analyzed.

The second chapter is about the methodology followed through all process of making this dissertation, including considerations on the choice of the theme, research planning, methodological development, research detailing, research tools used, as well as how data were processed and examined.

The third chapter is focused on interships reports at L'Air du Temps and at El Celler de Can Roca. The main objective was to acquire knowledge about how to work in a top restaurant, experiencing the food production process in all its stages. It was also intended to follow in practice the use of a set of techniques, in order to be able to select those important to develop for the work presented in this dissertation.

The forth chapter regards the developed work. Presentation of five dishes each one focused in one particular sense. Each one was the result of a deep study and analyse mainly of design and gastrophysics subjects. Correlating to the relevance of the bibliographic review that constituted a learning that is considered fundamental for the definition, and as conductor of the work, and finally the conclusions of an experimental work based on application of science to cooking and which involves de analysis of some processes through a scientific method to optimize results.

The modernist chef's food is designed to satisfy their guests' hunger, as well as to look good on the plate by feeding their mind [8].

The pleasures of the table reside in the mind, not in the mouth. 


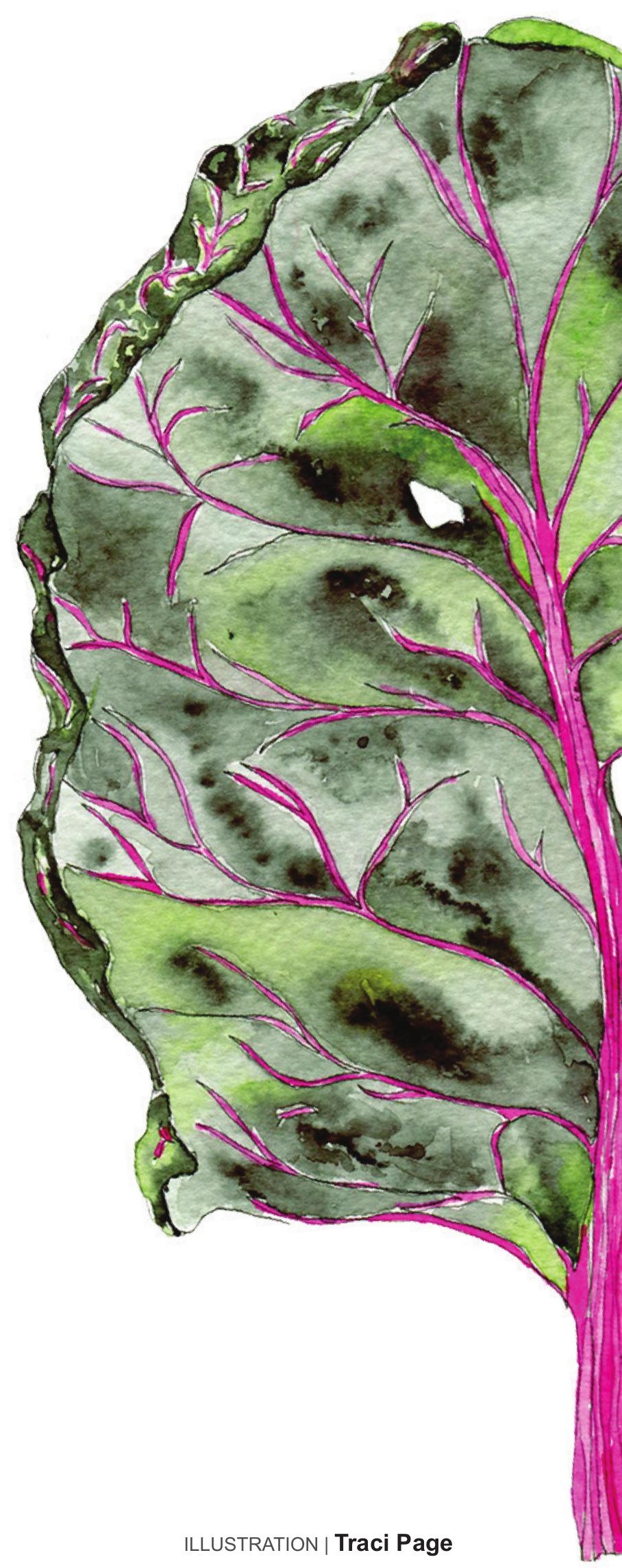




\section{CHAPTER 1 - LITERATURE REVIEW}

\section{$\propto$ \\ - GASTRONOMY \\ 1.1. Cook, Kitchen, Food And Gastronomy}

According to the Informal Dictionary (2016), Cook is a noun in the masculine singular, which refers to a person who prepares food for consumption. Larousse encyclopaedia, (1990), defines cook as a kitchen professional who practices his art in a restaurant, a private house, or a hotel. Referring that they have existed since the 5th century BC and since then they play a notorious role in society, using their imagination, virtuosity, sincerity and methodology. They are considered artists and as such their stage is the kitchen, place reserved for the confection of food [12]

Cuisine is defined as a cultural concept that systematizes the culinary practices and configures a proper disciplinary language. Cooking is a human activity par excellence, it is the gesture that transforms the product into something profoundly different, as a result of the chemical modifications induced by cooking and the combination of other ingredients [13].

Food refers to material and organic substances ingested by humans to respond to the vital need of nourishing. Food is not only tasted, but also thought and chosen. According to Massimo Montanari (2006), men through work and curiosity progressed and managed to transform the "starvations" into an occasion of pleasure.

Gastronomy is a term that first emerged in the 1800 s, was strongly associated with social status because it revealed the level of wealth, since what we choose to eat and the way we consume it defines lifestyle and creates distinction between social groups [14]. Hippocrates once he said "We are what we eat", besides referring to the medicinal side, he was also mentioning the cultural side. BRILLAT-SAVARIN, (2010), add the idea of material of gastronomy is all that may be eaten; its object is direct, the preservation of individuals. Its means of execution are cultivation, which produces; commerce, which exchanges; industry, which prepares; and experience, which teaches us to put them to the best use. Gastronomical knowledge is necessary to all men, for it tends to augment the sum of happiness. This utility becomes the greater in proportion as it is used by the more comfortable classes of society; it is indispensable to those who have large incomes, and entertain a great deal, either because in this respect they discharge an obligation, follow their own inclination, or yield to fashion [15].

\subsection{Culinary Evolution}

Prehistor was marked by new tools and hunting techniques [16]. At the beginning primitive man was limited to feed himself with what he would find, in its natural state, without great care or preparation of taste or texture [17]. Half million years ago emerged the fire that allowed to increase flavours and pleasure when eating, marking the starting point of the human civilization [18], [21]. This was followed by the first cooking utensils, manufacture of cutting tools, and later by agriculture and domestication of animals [21], [23].

It was in Greece that the term Gastronomy appeared for the first time in the fourth century BC. From Rome, came one of the earliest compilations of recipes, De re Coquinaria, written by Marcus Gavius 
Apicus in the XIV century and considered the leading Roman cookbook [17], [23], [25]. The Middle Ages were marked by monastic activity, winery and exaggeration of spices and herbs. Later in the Renaissance, the discoveries began a period of commercial and cultural expansion, mainly concerned to food products. Meanwhile, the first French culinary book was launched, Le Viandier, written by Guillaume Tirel, known as Taillevent. Which promoted the perfection of Italian high cuisine during the Renaissance [16], [17], [22]. It was at this time, Renaissance, that the culinary arts and the pleasures at the table, started being considered, changing the focus from quantity to quality.

With the discovery of America and the sea route to India, trade in imports and exports increased, as a result new foods were introduced into European cuisine. More attention was directed to the behaviour at the table, and hygiene in the preparation of the dishes. Old dry bread served as containers to serve the meals, working as plates. Then pastry was developed and jams, jellies, ice cream, marzipan, torron were introduced in Europe by Arab influence in this period [17], [22], [23], [26].

France and Haute Cuisine marked a new era full of techniques and culinary arts in the late 16th century, in which, for example, the béchamel sauce and the clarification of a consommé were introduced. Behaviors at the table evolved and objects such as spoons and knives started to be used. It was in the eighteenth century that the kitchen of the smell characterized by the intense use of spices began to be replaced by the kitchen of the sight, giving priority to the visual compositions, as an example of this are the famous and grand banquets of the Palace of Versailles [22], [23], [27]. This led French cuisine to a superior status, of luxury and splendour. The cuisine was assumed as a source of pleasure and chefs were officially recognized as real professional careers [22], [23], [26]. The eighteenth-century kitchen was inventive, looking for the new and creating. There was an alchemist spirit, and as a consequence the practiced cuisine wasconsidered the New Cuisine. With the French revolution the Haute Cuisine disclosed the pleasures of the table, leaving the private houses and palaces of the nobility for the restaurants. Culinary skills with creative freedom were developed [27]. The first restaurant in the world, was created in 1765 by Boulanger, on Rue Poulies, at the current street of the Louvre in Paris [17], [28]. With the growth of the restaurant industry French cuisine started to be respected all over the world due to its rich, tasty and sensuous gastronomy, a result of the various processes and cooking techniques. Shortly after the French revolution the book Physiologie du Goût, written in 1825 by Brillat-Savarin appeared [17], [23], [29]. Marie-Antonie Carême was one of the great French chefs, recognized by the architecture influence in his in his pastry work. Chefs were seen here as celebrities and artists [23].

Colours started to be combined with rigor and textures and flavours balanced. In the second half of the nineteenth century and in the early twentieth century AUGUSTE EsCOFFIER "king of chefs and chef of Kings", author of Le Guide Culinaire, simplified the techniques and ornamental style of Carême [17], [23], [30]. Escoffier set up the brigade system, where he allocates tasks within the kitchen staff, creating an organizational pyramid. He later joined CÉSAR RITZ and created a hotel empire full of luxurious restaurants that have made French cuisine a world reference [23], [27]. In the twentieth century stands out the creativity and greater freedom to the chefs, without any restrictions, rules and the limits of the past. Restaurant guides began to be published, the first Michelin Guide appeared in 1900. FERnAND PoInT's (1897-1955) cuisine was focused on the senses, seeking purity, balance and delicacy. He placed great importance on decoration, plateware and comfort on his restaurant where the menu changed every day [17], [23], [26], [31]. Then, at the end of XX century, came the Nouvelle Cuisine by the elite of French chefs looking for greater creative freedom. This movement included Paul Bocuse, Michel Guérard, PierRe and Jean TROIgros, ALAIN CHAPEL, among others. Characterized by small portions extensively arranged on large plates with elegantly presented sauces and minimal accompaniments [32], [33]. The satisfaction of the senses began with the vision, there was an artistic care, with special attention to the colours and forms, in which the dish was presented like a painted picture or a sculpture [34], [35].

Science had already crossed the kitchen path in 1679 when DeNIS PAPIN invented the pressure cooker and discover that was possible to reduce bones in edible gelatin. Around 1850 the chemist Justus von Liebig developed a manufacturing process for beef extracts, and founded a company, Liebig Extract of Meat Company . Later NichOLAS KURTI, a physicist at Oxford University in 1969 presented a lecture The Physicist in the Kitchen important as a turning point in the relationship between since 
and cooking [36], [37]. Hervé This in 1980 together with Kurti created the molecular gastronomy, defined as "a branch of science that studies the physico-chemical transformations of edible materials during cooking and the sensory phenomena associated with their consumption" [38], [39]. In 1984 HAROLD MCGEE released the book On Food and Cooking: the science and Lore the Kichen. Then in 1988 Hervé This wrote the Casseroles et Éprouvettes [33], [36], [40]. At the beginning of the 21st century there were some collaborations between chefs and scientists: Piere Gagnaire and Hervé This, Heston Blumenthal with Peter Barham and ANDY TAYLOR, ANDONI LUIS ANDURIZ and DANI GARCIA with RAIMUNDO Garcia del Moral, Ferran Adrià with Pere Castells, and Davide Cassı and ETTORE BocchiA [33]. Where the use of the scientific method and knowledge was applied to improve control of a food preparation and development of new techniques. Molecular gastronomy knowledge was used to optimize ingredients and preparation methods, as well as to innovate [36]. Contributing to new cooking movements named avant-garde cuisine, experimental, creative, progressive, modernist, or techno-emotional [41], [42]. This last one tries to transmit emotions through the specific experiences, culture and roots [43]. Dishes intend to provide a whole sensory experience, considering the visual appearance, the textures, the contrast of temperatures, stimulation of the senses, memory, nostalgia, comfort and euphoria. The technology gains great importance because it is used in quality products with the aim of maintaining the purity of the food despite the modification of certain characteristics or its appearance [42].

The latest movement was introduced by RENÉ REDZEPI creating what is called New Nordic Cuisine that is based on two main aspects: time and place. Highlighting that the way people eat, and the products used influence the world. That is, cooking involves responsibility, ethics, sustainability, geography, culture, politics and all these dimensions are consciously incorporated into Redzepi's cooking philosophy [44], [45].
1 "Creativity is the ability to generate new ideas and identify alternative possibilities in the search for solutions or answers to a problem or question. Creativity does not mean improvisation without method, in this way only confuses and creates in the young people the illusion of feeling free and independent artists. "In short term, for Adriá and elBulli, creativity is not a matter of food, eating, or liking something; it is a matter of expanding the repertoire of words that compose the culinary language" [50].

\subsection{Art \& Gastronomy}

The relationship between the territories of design and gastronomy has existed for a long time, right through the utensils used and in the dining spaces. In historical terms, the fields of design and gastronomy have a functional relationship and only recently has the food been brought to the design perspective [46]. Recently in the 20th century, several artists used food and other elements of the gastronomic universe as a means of expression, as an integral part of works of art [47]. The reasons food is increasingly being embraced as art are cause for concern and may even reflect something else: a shift in the boundaries of culture itself [48].

In 1909, Italian Futurism was founded, by FILIPPo Tommaso MARINETTI, who wanted to revolutionize art. The aim of the Futurists was to shock through irreverence, irony, audacity, and paradox. After having published Futuristist Cookbook in 1930 MARINETTI opened its own restaurant, Santopalato in Turin, Italy. Where the objective was to provoke, symbolic importance to food, working the cuisine and its various elements as aesthetic object [34], [47]. They asked the cooks to make edible works of art: "conceptual and significant productions, members of a verbal, plastic and synesthetic world." The dinners were characterized by a high scenic sense, playwright and by the acuity to the 5 human senses [34]. Then appeared the Eat Art movement in 1961. DANIEL SPOERRI was one of the great movers and shakers, he excelled in the use of food items as works of art, that is, food as a raw material in artistic creation. Then in 1968 SPOERRI opened his restaurant-gallery, Dusseldorf, where he exhibited works by Joseph Bueys, Roy Lichtenstein, etc. all made with leftover left on the plate [30], [47], [49]. 
BAYLEY (1991) states that "the cuisine implies the conception and execution of an idea, with the functional components embodied in a pleasurable whole ... that makes it similar to design". The similarities between design and gastronomy can be found in the permanent presence they represent in daily activities and in the importance they both have in the social, cultural and economic development of society. The gastronomic choices of an individual are revealing of their identity, habits, experiences or philosophy of life and materialize in constraints imposed economically and culturally. In this sense, gastronomy reflects society from its practices, behaviours and lifestyles and, like design, accommodates these dimensions when it creates "products" of everyday consumption. Both in design and in gastronomy there is a combination of artistic thinking with scientific and technological dimensions, with a view to a practical result.

\section{"BEAUTY WILL BE EDIBLE OR NOT AT ALL" SaLVAdor Dalí}

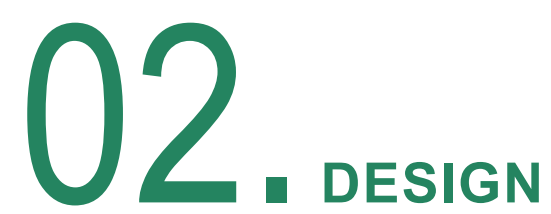

Knowing about design will help reading compositions, giving an easier aesthetic comprehension and shortening the way of feeding the senses. Nowadays restaurants focus on innovations and try to stand out as much as possible, but if the consumer does not have a constant supply that meets his expectations, the business loses credits and then dies. Wherefore the design is used as a working tool to maintain the standard of eating experiences, also the design has methodologies and tools that help to reinforce the concept of a dish. For example elBulli aimed to take creativity to an extreme by offering the interested public not merely new dishes, but new concepts with the potential to present opportunities to think differently about food, sometimes even at the expense of pleasure." [50].

Design and Gastronomy are parallel universes both involve a conception and an execution of an idea, always looking forward to satisfy its target to the fullest. A proper design must have a concept, be functional, have good materials, be well done and please visually. Good food also should have excellent ingredients and preparations, the result must be as much nutritive as tasty, besides of having a good look [51].

By Oxford dictionary, 2017, "Art is the expression or application of human creative skill and imagination, typically in a visual form such as painting or sculpture, producing works to be appreciated primarily for their beauty or emotional power." Gastronomy even though is an art, its aesthetic components are associated with colours, shapes, aromas, tastes and sounds [51].

Display of art has been shown to activate reward systems in the human brain. This is proved by KANDINSKY experiment were participants were willing to pay more for the artistic presentation of the dish [52]. It also shows that plating can have an important effect on flavour perception, so what is seen can indeed influence the perception of food. It was Apicius, the 1st Century Roman gourmand [53], who purportedly coined the phrase "we eat first with our eyes" [54].

Studying food presentations should be under the lens of design, psychology and sensory science, that could give precious insights to the so far empirical, art of plating. Designing the food on the plate aims to create movement and rhythm by using different sensory and visual elements that reflect the theme. The plate itself is a space, where movement and rhythm occur. Also, the room can give the meal a feeling of movement, protection, safety or rhythm [55], as well as light, sound and colours [56].

A meal without rhythm and dynamics is a dead meal evoking no sensations. Even the simplest meal is a matter of colours, composition, size, harmony, flavour and some other details. All these things have to complement each other and to challenge senses in a positive way [57]. 


\subsection{Design Definition}

Tschimmel (2014) says that many ideas, methods, approaches, dimensions or domains should be included in a universal definition of design, which has already been tried by various theorists and designers. According to MiLLeR (1988), design is the thought process that comprises the creation of something. Design as creation happens when a sequence or a set of events and procedures are filled by thoughts to produce what is being projected. Although, it is not only about thinking, also speaking, writing, drawing, building, moulding, etc. Briefly, the definition of design wraps three thought's aspects insight, intuition and rationality [58].

Design is a process of developing purposeful and innovative solutions that embody functional and aesthetic demands based on the needs of the intended user. Design is applied in the development of goods, services, processes messages and environments. And is not necessarily an art [59].

Design is a domain that can manifest itself in all areas of human practice and knowledge. It is future-oriented and related to innovation. The act of designing introduces something new into the world and aims at effective handling. Design is intended for interaction between the user and the appliance [60].

\subsection{Visual Composition}

Composition is the union of the elements, in this case food, in a conscious way. Although bad food won't be saved by a good presentation. For DoNDIS (2007), composition is the choice of appropriate elements to interpret and control a visual message concerned about who will receive it. Therefore, a social and cultural framework will state the aesthetic sensibility, it is significant to be aware about how everyone interprets the food composition. It is vital to innovate without shocking the target.

The fundamental principles of visual communication are features that when well applied transmit an aesthetic balance to food presentations, that will be perceived by consumer. [61].

There are three sets of elements to be consider: the conceptual elements (point, line, plan and volume); the visual elements (format, size, colour and texture) and the relational elements (movement, space and gravity) [61].

The Dot, marks a position in the space. In the centre is stable and dominant. Still may vary in size and in regularity, either can be used in isolation or in group. Furthermore bigger dots are associated to proximity and smaller dots to distancing. Also, a series of dots will conduct the look. The Line, is basically an extension of a dot, becoming a form with length without depth or width, used to create borders and outlines of plans. They are everywhere in a meal: food, plate, tables, chairs and surrounding area. Lines have positions, directions and purposes. Dots arranged in a row can evoke the direction of a line. The Plan, defines the extreme limits of a volume. Bounded by lines deals with the trajectory of a moving line creating a plan. Has length and width but no thickness. The Volume, defines the amount of space contained or moved by the plan, this means, the shape or space with depth, assuming three-dimensions (width, length and depth).

Form, format and shape, are the main visual elements, the difference between format and form is that format is an area easily defined by a contour, which gives volume and thickness and if seen from different angles becomes a shape. Shapes have depth and illusory volume. Form is two-dimentional, it has width, length and no depth, and is only possible to read its real form when the observer is placed in front of it. Everything that is visible has form, a plane shape is bounded by conceptual outlines, the edges, the characteristics of these conceptual lines and their interrelationships determine the shape itself. Thus, can be classified as: geometric, organic, rectilinear, hand-made, accidental [62]. Size, the big cannot exist without the small. Scale is established through relationships with the field or the envi- 
ronment, to represent a real proportional measure [61], Colour, Hering's theory of colour vision requires sensitivity to six basic colours: black and white, blue and yellow, green and red [62]. However, Helmholtz, argues that pure basic colours are only three: red, yellow and blue [63]. Clearly, referring to colour tint, primary tones are magenta, yellow and cyan. Secondary colours (orange, green and violet) are obtained by mixing two of the primary ones. Intermediate colours are the mixture between one primary and an adjacent secondary one. But also, neutrals must be considered (black, white and all intermediate greys) as well as all tonal and chromatic variations. The last dimension of the colour is achromatic, the relative brightness. Thanks to the tone we see the depth, distance and other references of the environment. In other words, tonal value is another way of describing light. Texture, is related to how sensory physic features are perceived (heard, saw and touched), these are results of internal structure of the material [64]. Here texture refer to tactile texture, visual texture or both combine. The visual texture is strictly two-dimensional, it is the kind of structure that is perceived by the eye and evoke tactile sensations. The judgment of the eye is usually confirmed by the touch and might be described as smooth, rough, creamy, crunchy, soft, solid, fluid.

Movement, a relational element, is observed through tensions and some compositional rhythms that can make a composition energetic and stimulating [61]. The eye also moves in response to the unconscious process of measurement and balance through the "sense axis" and left-right and high-low preferences. Space, can be positive or negative, flat or illusory, ambiguous or conflicting. What dominates the eye in visual experience would be seen as a positive element, and everything that presents itself more passively is considered as a negative element. Gravity, its a psychological perception. Humans are attracted by the gravity of the earth, tending to attribute weight or lightness, stability or instability to formats [62]. Direction, depends on the way something is related to the viewer, on the frame that contains it or on the close formats around. All basic forms express three basic and significant visual directions: square, horizontal and vertical; triangle, diagonal; circle, curve [61].

In a quote Spence (2014), refers which techniques are related to the perfect meal: "balance, unity, harmony, variety, rhythm, emphasis, contrast, proportion, pattern and movement". So, these are considered to implement some order in the aesthetic compositions as diversity without order can produce chaos. Visual techniques should not be thought as extremes of exclusive meaning for the construction or analysis of everything that is seen. Every technique can be transformed into smaller degrees of intensity.

Balance, can be formal when both sides are symmetrical and informal if not symmetrical. An equal distribution of weights, regular and well-ordered harmony can generate a strong visual attraction and pleasant aesthetic composition, ideal for dish plating. An unbalanced composition can sometimes seem accidental, carefree and unconcerned, contrarywise in some cases might be dynamic. The equilibrium can be obtained by varying elements and values, which is equivalent to a compensation equilibrium [52]. Symmetry is the axial balance, it is a visual conception characterized by absolute logic and simplicity, but it can become static and even boring.

Unity, is an adequate balance of diverse elements in a visual perceived totality, in such a harmonized way that would be seen and considered as a single thing. In the other hand, fragmentation is the decomposition of the elements and units of a design into separate parts [61].

Harmony, is more than balance, agreement and uniformity, it is a pleasant visual effect by the well-ordered and organized layout referring to all features, scale, sequence, proportion, symmetry, conformity and consistency. All parts of the composition relate and complete into a coherent whole, that allows for a simple and clear reading [62].

Variety and Contrast, on a white background the darker colours stand out much more than the lighter ones and thus seem to be closer to the eyes. On a very dark background, the reverse is factual. If a drawing has hot and cold colours, the warm colours usually move forward, while the cold ones seem to retreat. There is contrast everywhere and it can be by format, size, colour, texture, direction, position, space and gravity. Basically, contrast is a comparison, in which the differences become clear. Contrast can be used to highlight some specific food or shape within the composition of a dish [65]. 
Regularity, in design is the favouring of uniformity at elements, and the development of an order based on some constant and invariable principle or method. Some examples in nature are leaves of a tree, grains of sand on a beach. Oppositely, the irregularity as a design strategy emphasizes the unexpected and the unusual, attracts attention and relieves monotony [66].

Simplicity, usually is related to order, a visual technique that involves immediacy and uniformity in an elementary way, free from complications or secondary elaborations. A visual complexity is constituted by numerous units and elementary forces. However, complexity becomes interesting when it balances entropy and order, chaos and cosmos. "Clarity and simplicity, requires the minimum of possible units, allowing the essential" [67]. Examples of cuisines in which simplicity is highlighted are Nouvelle cuisine or Japanese cuisine [66].

Profusion, presents the complexity, composed of several units resulting in manifestations loaded with superfluous elements. A profusion dish will set the receiver immersed in an environment full of disturbances that can alter or even cancel certain sensory character [62].

Saturation, "is the second dimension of colour, it is the relative purity of a colour, from hue to grey." A saturated colour is simple, almost primitive. The less saturated colours lead to a chromatic neutrality, and even the absence of colour, being subtle and restful [61].

Subtlety, is the best technique to make a sharp distinction. Furthermore, suggests a delicate visual approach and extreme refinement [66].

Transparency, allows objects or overlapped objects to be viewed. Otherwise opacity "implies the blocking or concealment of visual elements in all" [61].

Distortion, considered as optical illusions, and associated to more studied and intentional forms of accuracy, for example trompe d'oeil. Whereas, distortion adulterates realism [62].

Depth, perspective is the method for creating many of the special visual effects of the natural environment. It uses many devices to simulate distance, mass, point of view, vanishing point, horizon line, eye level, etc. Plains and depth are governed by the use or absence of perspective. Consequently, depth only exists when there is perspective using colours, successions of elements, textures, lines, glows and shadows [62].

Pattern, randomness is a rhythmic scheme, not sequential, producing a sense of absence of planning, intentional disorganization or accidental presentation of visual information. Besides, sequentially is based on a logical order with a rhythmic pattern [62].

Gradation, a progressive successive increasing or sequent decreasing of exposure of elements, examples of this: gradations of size, direction, colour. Considered as dynamic cause obligates our eyes to look through, creates optical illusion and produces a sense of progression [62].

Concentration, refers to the mode of delivery of shape units, which may be densely packed or sparsely distributed, this concept is linked to density [66]. 


\subsection{Design Process}

According to ARCHeR (1965), the problem of design results from a need. ScHON (1985), describes design as a complex, subjective, synthetic process in which there is no "right" solution but only conditioned responses by situation and experience. Accordingly, the design process varies between different projects and design fields, becoming a network of "projected movements" and of emerging consequences and implications [68], [69].

Creating successful products requires the skills, expertise and craft of many people, the transdisciplinarity among engineers, specialists, analysts, strategists, designers, researchers, architects and marketers is required. Joining diverse personal characteristics: analytical, creative, strategic and pragmatic, and using many working approaches: structured, unstructured, empirical, theoretical, etc., becomes essential for the design process. The designer is predisposed to uses several types of drawing, simple sketch, constructive drawings, perspectives, axonometries, exploded drawing, photomontages. As well of being aware of reuse, perception, bionics, proxemics, ergonomics, lighting and moulds [68], [70].

OsBORN (1953), divides the design process into understanding the problem to solve and gathering data, creating as many ideas as possible and selecting the most appropriate, and finally evaluating the chosen solution and implementing it. Swann, 2002 alleged 6 elementary phases: problem, analysis, synthesis, execution, production, evaluation [68], [70].

MUNARI (2010) identifies 7 steps in project methodology: Enunciation of the problem, according to a need analysis; Identification of aspects and functions, physically and psychologically; Limits, period of validity, quality materials, prohibitions or limitations and market requirements; Technological availability; Creativity; Models; and Prototype.

Similarly, for DoNDIS (2007), first comes the sketch, then comes the production drawings, rigid and mechanical. The engineering and technical requirements. Finally, the elaboration of a model may be the only way to see how a certain thing is going to remain in its final form.

The British Design Council (2005) presented the Double Diamond model, the creative process for tangible objects, concerning different approaches. Representing the "divergent thinking stage" and the "convergent thinking stage" by a diamond shape. The double diamond form happens twice, once to confirm the problem definition and once to create the solution. This simple visual map is divided in 4 phases. Discover, the start of the project, where designers try to look at the world in a fresh way, notice new things and gather insights. Define, in which designers try to make sense of all the possibilities identified in the Discover phase. Stating what really matters, defining priorities, and ponder possibilities. Develop, where solutions or concepts are created, prototyped, tested and iterated. This process of trial and error helps designers to improve and refine their ideas. Delivery, where the resulting project (a product, service or environment) is finalised, produced and launched. These methods are not rigid protocols to be followed unthinkingly, but frameworks that can and should be adapted to the task at hand [1].

FiguRE 1. Double

Diamon design process, Brithish Council

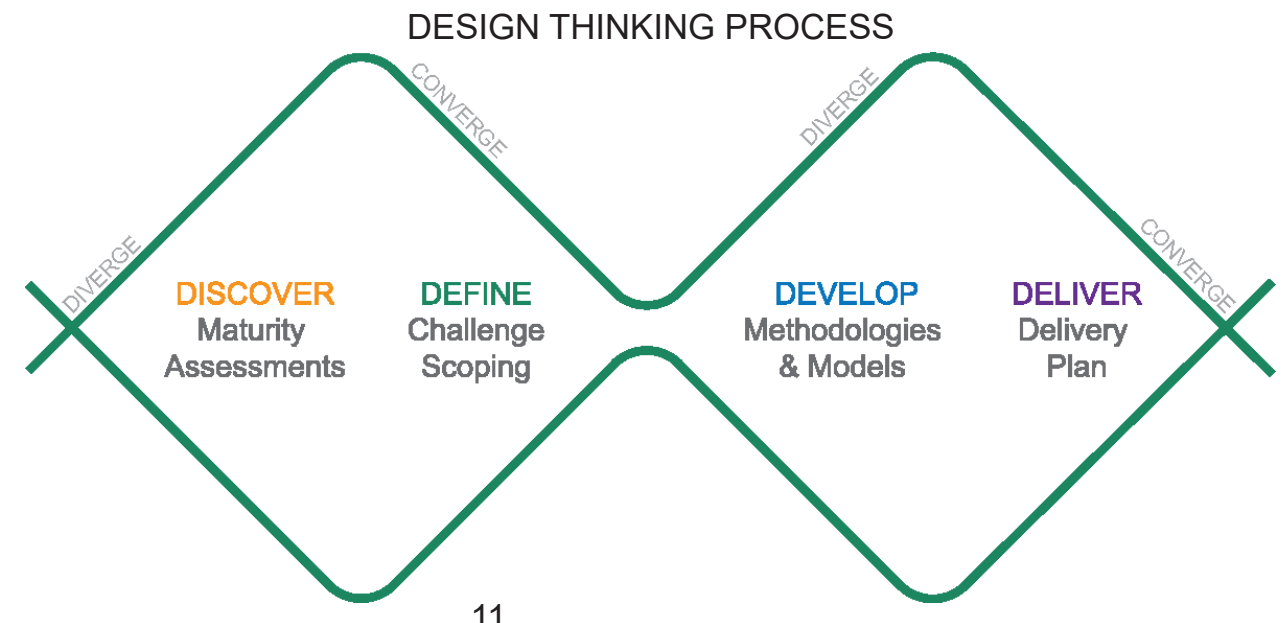


Any cookbook is a design methodology book. The recipe is no more than a series of necessary operations, arranged in logical order, dictated by experience. Proof of this is the Bruno Munari Project Methodology, which defines the methodology steps based on a green rice recipe [65].

\subsection{Chefs Creative Process}

Nowadays, the chef has become a creative artist capable of producing amazing experiences for his clients. So, creative thinking and experimentation are encouraged. Creative food products combine science and art, novelty and values [72]. A creative food product not only feeds from the physiological point of view but also feed desires. Today, creativity is the apparatus of competitivity in the culinary industry.

The processes of food preparation and design practice have many aspects in common when planning, preparation and execution, also in several projects the line separating the role of a chef and the designer is tenuous [73], [74].

Chefs apply their knowledge on the conceptualization, techniques and methodologies. Also, the selection of the dish and / or container for the presentation of the food is based on the artistic vision of the chef.

There is a very important concept associated with the Chefs' culinary competence, which balances 7 interrelated factors: Creativity, Culture, Aesthetics, Technology, Product, Service, Management [75].

Ferran Adrià Ex-Chef of elBulli restaurant, analyzes, studies, researches and then launches his innovation. Currently at elBulli Foundation, always with a creative culinary vision, his relationship with design is not just conceptual, but also pragmatic. He takes everything into considerations, even the kitchen utensils and the plateware. He is the first cook to interrelate food with design in a profound, integrated way. He has involved several artists and designers in his research [14], [30], [48].

The structure, hierarchy and values associated with the creative process of both, design and cooking, manifest themselves in a similar way, integrating methods and procedures based on experimentation and criticism and on the creation of prototypes [76].

The proposal of OtTENBACHER and HARRINGTON (2007) considers a model with seven steps (see figure 2) from the moment in which the ideas are generated until the commercialization of the plate; Generating ideas, Screening, Attempted and Error, Concept Development, Final test, Training, Selling [77], [78].

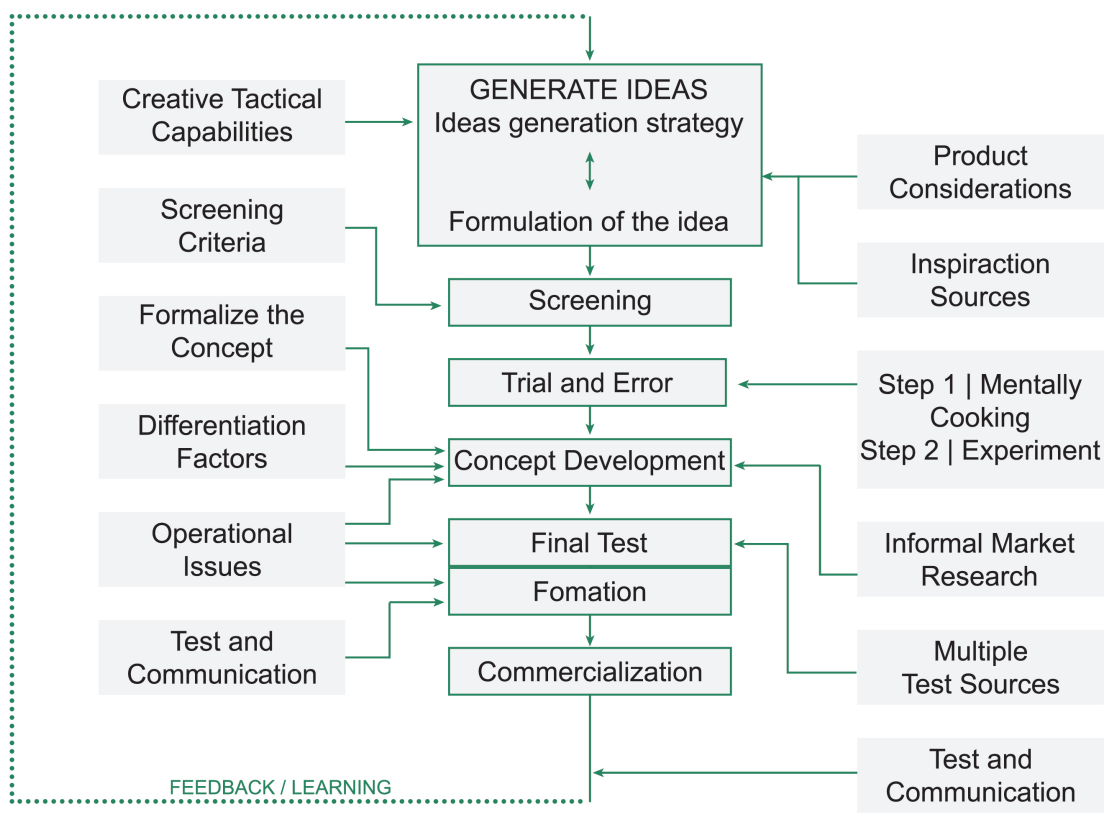

FIGURE 2. Model development process and innovation of michelin star chefs - adapted from Ottenbacher and Harrington (2007: 444) 


\subsection{Gastronomy and Design}

Eating is a compulsory daily act supported by an enormous range of skills and objects. It is an activity that is always associated with the objects that make it easier. Or, sometimes, more difficult. [79] "Food and design are ubiquitous and necessary for everyone, but both are confronted with processes of power that can greatly affect public access to both. Food is a biological requirement, while the design is not. Yet the human being never existed without some form of design, starting with the first tools, which were actually needed to get food " [80].

In historical terms, the fields of design and gastronomy have a functional relationship and only recently has the food been brought to the design perspective, in terms of topics such as collective consciousness, tradition, the instrumental or recreational character of the act of eating [46].

Although cooking, in the sense of cuisine, defines a cultural construct that systematizes culinary practices (techniques, ingredients) and configures its own disciplinary language. "Design is crucial to understanding various aspects of the food system in general, from the shape of a fork to the visual elements of a dining room, from reducing kitchen waste to the sustainable distribution of supply networks. When aimed at improving the food system and eating experiences as a whole, design strategies have the potential to link concepts such as healthy and enigmatic, vernacular to concept and traditional to modernism and humanism to technology" [81].

The relation between design and gastronomy is based on a common projective perspective to which they converge: the senses; materials and ingredients; society, with its history, traditions and specific geography; the ability to develop or use an innovative technique or technology; scientific developments; the creative practice in the design and implementation of the final result.

Great sensorial experiences can be created getting design and gastronomy together. According to OliVEIRA, (2010), gastronomy has an aesthetic dimension composed by shapes, colours, aromas, tastes and sounds, resulting in various sensations that aesthetic elements can awaken in people. From here comes the need of Food Design, a design segment that deals with the conscious design of products, where food and tools interact with each other. They form a single interface, which has the capacity to solve the requirements related to the consumption of a food product. Thus, the design when united with the food makes the food material become an object of use, functional and useful, meeting the nutritional, visual and gustatory needs. "Food turns from mere fuel into something meaningful, through a careful combination of tastes, textures, odours, colours and shapes." [51] The connection between design and material culture is also reflected through its relation to food. Since ancient time man has produced ways to transform, preserve and eat food. As a constant need for human survival, attention to food production has been an important issue for design [82], [83]. 


\section{FOOD DESIGN}

\subsection{History and Evolution}

Without design, eating would be more difficult and boring. [78] Food would be a question of mere survival. Breathing and eating are the overriding necessities of life. Human ingenuity and design have been improving the way we eat for centuries. This ingenuity has also produced weapons and tools for hunting and fishing. Subsequently, design is again of crucial importance for developing tools for producing and cooking food, preparing it, transforming it and preserving it. Without pots, pans or skimming ladles cooking would be extremely difficult. Good design is also of fundamental importance for all tableware the items. The design of implements for the table, apart of making them functional, also confers them a high degree of symbolism and representation establishing a relationship between design and art" [79], [84].

The history of crockery is remote and covers all kinds of recipients. The dishes, until the 13th century, were usually made of wood. The most luxurious dishes were made of metal, copper or silver, and were reserved for the wealthiest. When the production of glazed earthenware pottery became widespread, and later on the production of porcelain, two specific kinds of plate were produced: a flat carving dish and concave dishes or soup bowls to contain more liquid ingredients. There was a revolution in tableware such that plates, glasses and cutlery acquired great importance and every family aspired to have them, usually given as wedding gifts [79].

The modernization of kitchen furniture started in the 1960s, new kitchens were more rational in their design and they incorporated new facilities and materials such as melamine laminates and Formica [55], [79].

\subsection{Definition}

"Food as design is a language, a culture with its own traditions that satisfies needs that go beyond the shape and the pleasures of aesthetic, taste and other senses. The contribution of design to the food world is multifaceted and goes from the material dimension to the most immaterial one." [83] It is a new brand field and it is not considered as a subject yet, it lacks academic consolidation because it is too comprehensive and interdisciplinary.

For StummereR, (2010), the notion of food design refers to the development and shaping of food. So, this includes all the decision-making processes related to the success of practicing food design. This applies not only to the appearance of the dish or product, but also to the design of taste, consistency, structure, surface, sounds, smell and more. Connecting food and design means connecting any aspect of food with any aspect of design. Reissig (2016), affirms that "Food Design includes any 'action' that can improve our relationship with food individually or collectively in diverse ways and instances, including the design of food products, materials, experiences, practices, technology, environments and systems." Food Design is an area that can manifest in all areas of practice and knowledge of gastronomy. It is oriented towards the future and related to food innovation. Food Design is related with the interaction between the user (costumer) and the food - whether it is a product, service or experience. 
Food Design looks at the food system through a holistic view [4].

Another generalist designer, MARTí GuIXÉ 2016, states that "Food design is the design of food, which is thought, perceived, contextualized, ritualized, implemented and consumed as an object". So, ZAMPOLLO, (2017), proposed a generalist definition "Food Design is the connection between food and Design. Food Design is the design process that leads to innovation on products, services or systems for food and eating: from production, procurement, preservation, and transportation, to preparation, presentation, consumption, and disposal" and for better interpretation of this definition she established some categories: Design with Food, Food Product Design, Design For Food, Design About Food, Dish Design, Food Space Design, Food Photography, Food Stylist, Concept Food Art and the last new trend is Eating Design [85]. A very common mistake is to assume that Food design is responsible for making a product appealing and beautiful to the consumer's eyes. This is partly wrong since this is called Food Styling or Dish Design, which relates to a segment of the Food design. However, the concept was starting to be over used so Vogelzang (2008) defends the new sub category "eating design" affirming that "Food Design is part of a larger field which she calls Eating Design. Food Design is the actual and literal design of food where food, as matter and thus material, is being designed. This could be to enhance the eating experience, but it could also be to communicate an ideology or to fight food waste. Food design is an important part of Eating Design. Eating Design is the practice of designers working on the subject of food. The outcome is not necessarily the material of food. It can also be a system or a service. Eating design covers a large field connected to science, psychology, nature, culture and society" [86].

Some examples for Design with Food are macaroni with its characteristically cylindrical and striated shape is the result of an ingenious design intended to ensure correct cooking and to retain the sauce. It has been consciously designed, its shape is not determined by chance but by human premeditation [46], [85]. Another example for Design for Food is a non-drip olive oil pourer designed by Rafael Marquina, 1961, as an object of daily use to substitute the traditional glass oil bottles used at table that always dripped. Any drops of oil escaping from the spout are returned to the base through a small inverted cone with a ridge in it which also allows the escape of air when pouring the oil [79].

Food is an edible art and the eating experience is the process that transforms sensorial perceptions into emotions, knowledge and memories. The stimulations are numerous and analyzing all of them is a complex issue, but Food Design helps understanding these inputs and deals with everything that improves our relationship with food and all the design applied to food products, material, experiences, practices, services, technology, environment and systems.

\subsection{Future and Innovation}

Nowadays, the high rate of innovation resulted in saturation and makes difficult to keep abreast of everything happening in gastronomy. We live in an era of customization, of personalization, in which all cooks seek the freedom of the creative space that defines them. For cooks, innovating on the cooking techniques is indeed the most challenging goal to achieve. To achieve this, certain professional kitchens are becoming full equipped and in some cases a special division, named as Lab, is created to develope work in innovations products development. A variety of equipment is now applied for cooking: candyfloss maker, electric drill, centrifuge, encapsulator, deep freezer, blast chiller, dry matter scales, freeze dryers, overhead stirrers, pH meters, refractometer, rocket evaporator, rotary evaporator, vacuum oven, smoking gun, water-baths vacuum fryer, blow-torches, siphons, and even a fish-tank air-pump. All these are forms of design, this demonstrates that the design is present in all aspects of food production [6], [87].

Very recently the concept of Multisensorial Dining Experience has been growing. One of the firsts to develop this idea was veteran chef JuAn MARI ARZaK with Jon Rodríguez and PHILIPS, creating a series of interactive containers that react on contact with the food, emitting sounds and vibrations and generating luminescence and moving images. But the most ambitious innovation was created by the Roca brothers, was El Somni (The Dream, in Catalan), an integrated, multidisciplinary visual exploration 
directed by FrANC Aleu. It is a gastro-opera in twelve acts with twelve courses, and is also an exhibition, a book and a film made by Mediapro [57]. The most recent project Sublimotion opened in 2014 at Ibiza's Hard Rock in Spain, being the world's most expensive restaurant. With a combination of cutting-edge technology and a crew of leading professionals and artists from the world of gastronomy, drama, music, art, design, technology, magic, illustration and neuroscience [88].

Another revolutionary invention is $3 \mathrm{D}$ food printing, which increases the production capacity, overcoming the limits of craft manufacture, creating very complex structures that would be impossible in other ways. The first 3D Printer appeared in 1984, created by CHARLEs HuLL, founder of 3D Systems Crop. It mainly works by Fused Deposition Modelling, the objects are printed layer by layer until the final shape is formed. 3D food printing opens the door to food customization and personalized nutrition. Besides the printer can ensure that your personalised meal is made at exactly the right moment so that when necessary, a fresh, healthy meal is produced. This convenience can lead to flexible decentralised (local) production [89]-[96].

There is still a whole world to discover enabled by technologies, however a social and economic validation is required. Food is losing authenticity and flavours for many reasons like aesthetics for perfection pursuit, massive productions, loss of culture, economic crises, social and cultural prejudice. Designers should work aside Chefs in order to respect the originality of products [8]. 


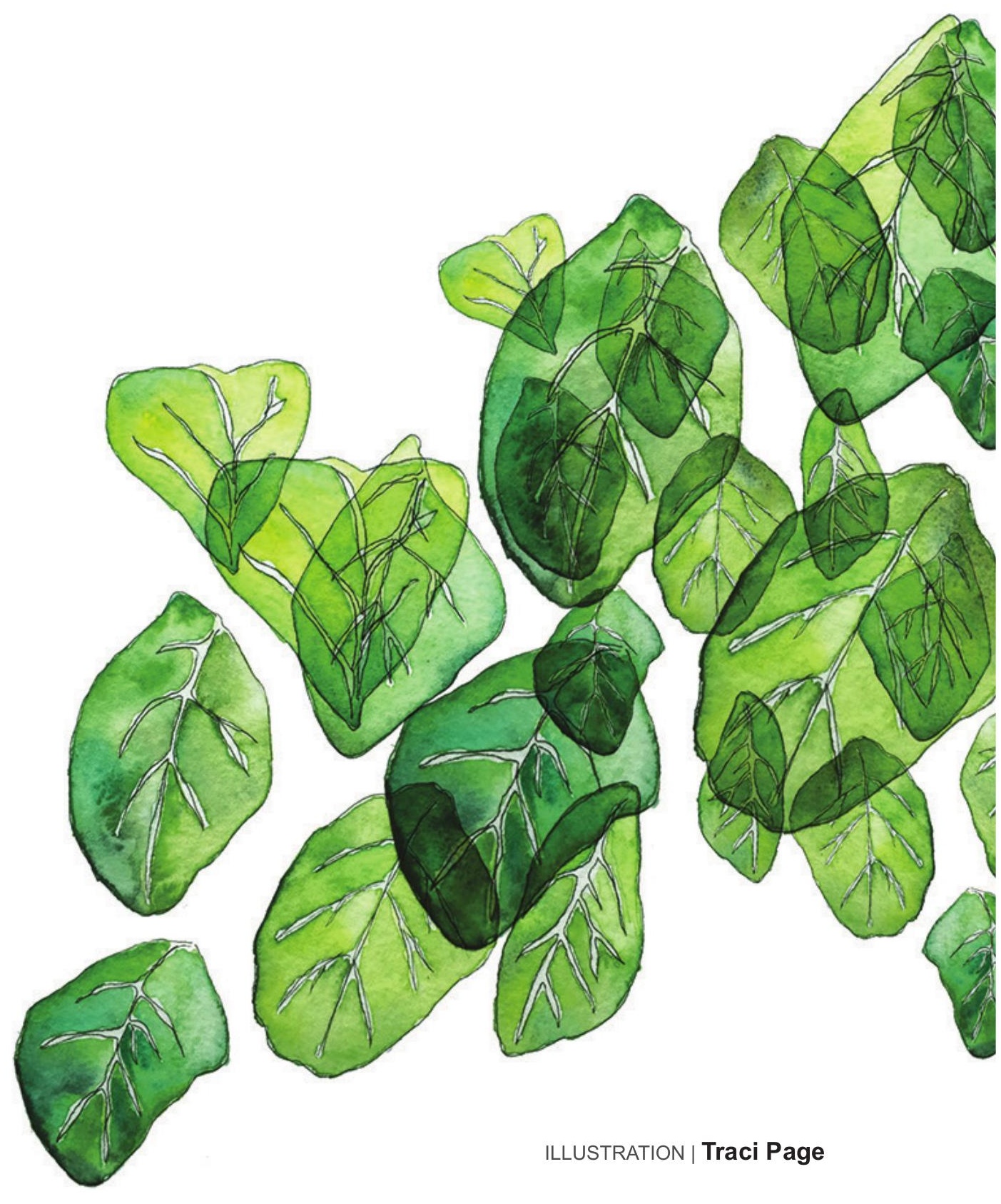




\section{PSYCHOPHYSIOLOGY}

Food Design is to write or rewrite stories based on the palate, anchored in various senses, first through sight, through smell, touch and taste [97]. People perceive and appreciate food in a manner that is multisensory [52]. Environment, cutlery, plateware, colour, texture, they all influence on the perceived flavour and acceptance of foods. Thus the five senses become one of the most important reference points in the creative process of the kitchen [98]. This can be seen for instance in plates that differ not only in colour and shape, but also in the sounds they make [55].

KüPFMÜLLER (1962) estimates the inflow of information to human senses to be between 10 and 100 million information units (bits) per second [55], "The realization of a new dish must also be accompanied by an unprecedented presentation, in which colour, shape, volume and texture are as much, or more important, as the flavour of the cooked ingredients" [14]. A dish is a unit of analysis, an image not only visual, but also gustatory, olfactory, tactile and sonorous.

\subsection{Visual Communication and Perception}

According to MUNARI (2010), getting to know images that surround us means enlarge the contact possibilities between reality, implies to see and understand more. The visual communication can be intentional or casual, all the images have a different value according to the context in which they are inserted, transmitting different information. According to GoMES, (2003), the Gestalt movement studied the perception and the language of the forms. Gestalt Theories have arisen to explain why some forms please more than others. Composition is intentional by artist, designer or chef, states your input.

According to MONTANARI, (2001), in gastronomy the aesthetic factor is important, since the look activates salivation, which anticipates the production of the gastric juices in the stomach, improving digestion. A dish that has harmony in form, colour and other aspects, has the ability to "nourish" the eyes and excite the fantasy before food can touch the lips.

The Department of Culinary Arts at the University of Örebro bases its educational approach on five aspects of the meal [56]: the food itself, the room, the service, the atmosphere and the economic control system. Consciously or unconsciously, diners experience all sorts of other sensory information: verbal and non-verbal communication with serving staff, the atmosphere of the room: light, colour, sound, directions and movements. There is also noise and body language from other guests, the odour of different bodies and the scent of food. These may both enhance and destroy pleasure.

A form that contains a recognizable theme communicates with observers in more than purely visual terms. Natural forms include living organisms and inanimate objects that exist on the earth's surface, in the oceans, or in the sky. Man-made forms are figurative forms derived from objects and environments created by man. Organic shapes are formed by curves that flow smoothly with imperceptible transitions or protruding connections. For geometric formats it is essential to use rulers, circles and arcs with compasses. Sharpness and precision should prevail [62]. 
Liking of visual objects has been shown to be affected by factors such as symmetry, prototypicality, contrast, complexity, and perceptual fluency [99]. There is a preference for the lower left-hand corner because there is a primary sweep pattern of the field that reacts to vertical-horizontal referents. Indeed, previous studies of human facial expression and interpretation of movement suggest that sharp primitive elements (e.g., a V-shaped corner) convey threat, whereas round primitives convey "warmth" and that curvature elicits increased positive emotions [99].

\subsection{Colour Psychology}

"COLOUR IS FOREVER A PART OF OUR FOOD, A VISUAL ELEMENT TO WHICH HUMAN EYES, MINDS, EMOTIONS AND PALATES ARE SENSITIVE. PERHAPS THROUGH EONS OF TIME, MAN HAS COME TO BUILD UP STRONG AND INTUITIVE ASSOCIATIONS BETWEEN WHAT HE SEES AND WHAT HE EATS" [52]. [100].

The visual aspect of a certain dish or food gives cues about its flavour. Even at a certain distance the visual impression awakens desire or repulsion. [11]. Colour can induce: sensations of heat or cold, dry or damp, smooth or rough, soft or hard etc. For instance, the temperature of a colour is determined by its tendency towards yellow (hot colour pole) or blue (cold colour pole) [101]. Also, colour has affinities with emotions [61].

Yellow is the colour that is considered closest to light and heat; red is the most active and emotional; blue is passive and smooth. Yellow and red tend to expand; the blue, to twitch. When joined through blends, new meanings are obtained. Red, a provocative hue, is softened when blending with blue, and intensified when blending with yellow.

According to Rıccò, (2008), Aristotle in his work "From the Sense to the Sensible" makes a correspondence between seven colours and seven flavours. They are: yellow $/$ white = greasy $/$ sweet; red scarlet = rough; purple = almost spicy; green = sour. Later, another study, conducted by FEVRE in 1979, found that: the sensation of acidity is caused by shades ranging from yellow to green to olive green; the sweet sensation is caused by colours ranging from yellow, through orange to red; the sensation of bitter is provoked by shade ranging from purple, through brown, to black; and finally, the salty sensation is brought about by shades of greenish grey to bluish grey.

The German sociologist Eva HeLler, (1989), conducted an experiment with 1888 people. The experience consisted in associating the colour with the four basic tastes - bitter, sour, salty and sweet. Green and yellow were predominantly associated with sour, while pink, orange and red were associated with sweet. The white, the grey and the blue to the salty taste. Violet, black and brown to bitter [102]. The user / consumer likes foods with colours that remind him of foods in their natural colour. Colours like red, orange, yellow or green are associated to ripe fruits or crisp vegetables. By contrast people have an instinct that inhibits them from eating colours like black, violet or blue, or colours that convey the idea of artificial. In reality, there are not many foods in their natural state that are dark or blue, and that is why people do not feel comfortable to ingest them. The dark colours are indeed the least appealing in the food choices of most consumers [63], [103]. GISLA GNIECH, 2008, conducted some experiments dying food. Dyed potatoes with black, cauliflower with green and asparagus with red. Although the taste remains the same, the groups subjected to the experiments felt reluctant to ingest the colour modified foods [9].

Spence states that colour can be used to modify people's perception of a taste. It is possible, for example, make food or drink taste sweeter by adding a pinkish-red colour. Responses to colour in food and drink aren't fixed but change over time [8] .

It is important to be aware that each one experience, traits and cultural can influence the perception and meaning of colour. Each colour has countless associative and symbolic meanings [103]. 
Morning light contains more blue/violet, with shorter wavelengths, which give more energy. Afternoon light is warmer, more restful, with more red/ orange hues and a completely different feeling from the morning. Electric lighting provides what is called 'striped' light. Thus the light also influences the perception. Colour of food changes as it passes from kitchen to dining room and looks different again outdoors. This can make an enormous difference to the presentation of food because a brilliant colour in the kitchen can look dull or unappealing in the dining room. The way the colour of food is perceived also depends upon the colour (and shade) of the plate, the tablecloth and the other things on the table [55].

\subsection{Sensory Perception}

Nowadays, neuroscience, psychology, social sciences or gastrophysics seek to establish parameters that, being common to all individuals, can, provide a multi-sensorial gastronomic experience, but above all contribute to the change in human eating habits.

A new range of plateware concepts by PHILIPS DESIGN, explores how the integration of light, conductive printing, selective fragrance diffusion, micro-vibration and the integration of other sensory stimuli might affect the eating experience [64].

The sensory systems is responsible for generating, internally, a representation of everything around us. Through the senses, we perceive reality through its chemical characteristics (through taste and smell) and its physical characteristics (through touch, hearing and vision). Since Aristotle 5 senses are recognized, at the moment, Harvard neurologists discuss the possibility of the existence of others, such as: equilibrium (perception of balance), nociception (perception of pain), proprioception (perception of body position), thermoception (perception of temperature), chronoception (perception of the passage of time), and interoception (perception of stimuli internally, such as breathing) [104].

Most activities of the nervous system are initiated by sensory experience exciting sensory receptors, whether visual receptors in the eyes, auditory receptors in the ears, tactile receptors on the surface of the body, or other kinds of receptors. This sensory experience can either cause immediate reaction from the brain, or memory of the experience can be stored in the brain for minutes, weeks, or years and determine bodily reactions at some future date. Senses can be translated into emotions that are connected to the involuntary nervous system. That is why a bad taste or odour can bring out vomiting or nausea. On the other hand, flavours that are appetizing increase the production of saliva and gastric juices. Perception of reality and food, in particular, is done in stages: $1 .^{\circ}$ appearance through vision; $2^{\text {nd }}$ odor, aroma and / or fragrance perceived by smell; $3^{\text {rd }}$ consistency and texture related to touch; and the $4^{\text {th }}$ flavour.

According to the International Standards Organization (ISO 5492 1992, 2008), flavour can be defined as a "Complex combination of olfactory, gustatory and trigeminal sensations perceived during tasting". The flavour may be influenced by tactile, thermal, painful and/or kinaesthetic effects. Of course, this is not to say that oralsomatosensory, visual, and auditory cues can't modify a food's flavour, they most certainly can [105].

Exteroceptive senses as vision, audition and orthonasal olfaction are stimulated prior to the consumption of food. On opposition, interoceptive senses of gustation, retronasal olfaction, trigeminal stimulation, oral-somatosensory, and the sounds that are experienced while eating and drinking. 
Figure 3. Somatosensory axis of the nervous system, Guyton and Hall (2006)
2 The synapse is the junction point from one neuron to the next, they determine the directions that the nervous signals will spread through the nervous system, normally passes only in the forward direction (from the axon of a preceding neuron to dendrites on cell membranes of subsequent neurons). "Nerve impulses," are created through a succession of neurons, one after another [125].

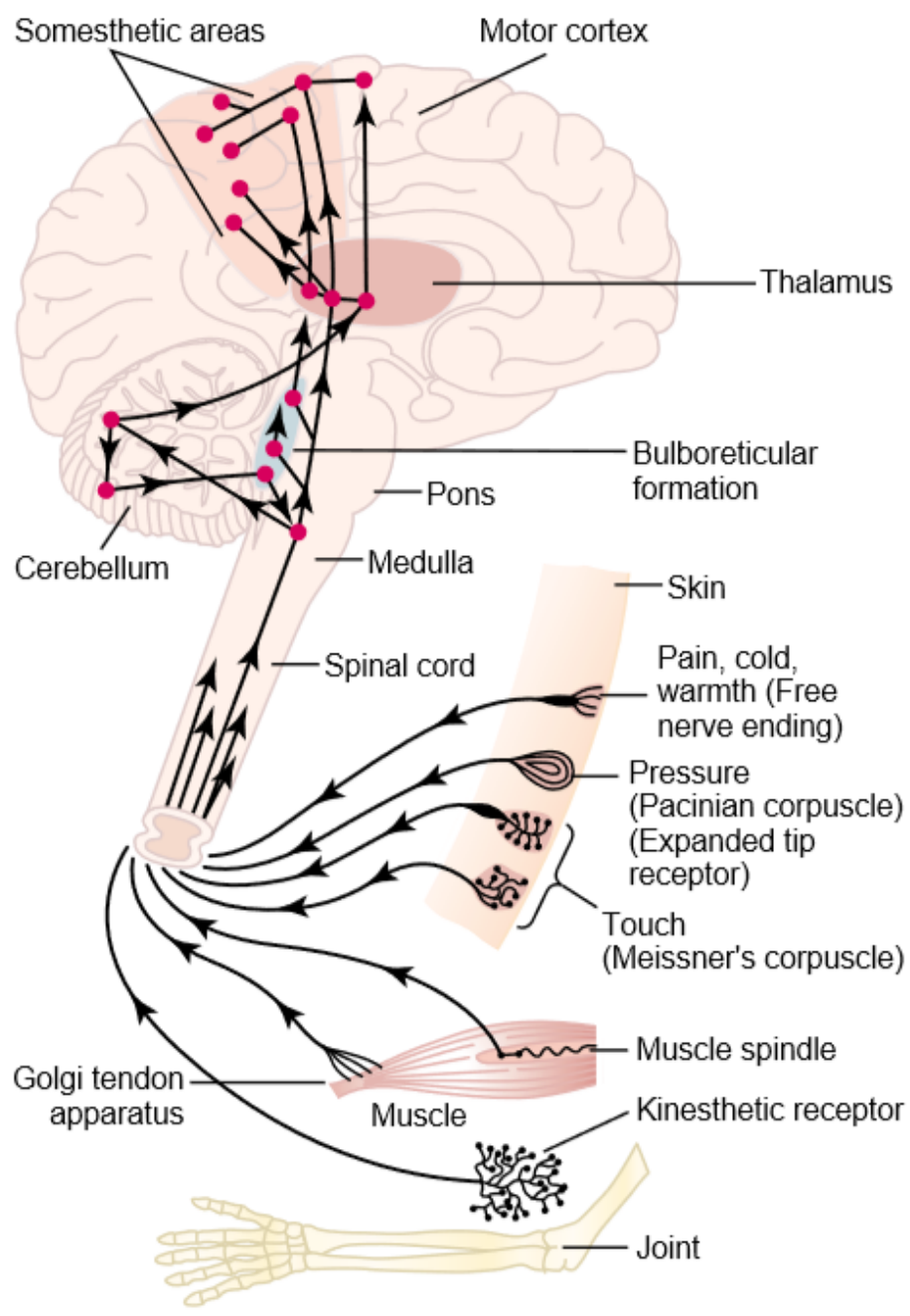

The task of eating a meal, for instance, involves a barrage of inputs from the different sensory modalities, some of which are combined in the perception of flavour. Crossmodal correspondences (or associations) may thus reflect a strategy by which the human brain can quickly and effectively deal with complex sensory inputs; as SPEnCE and ZAMPINI, (2006), put it, a "range of implicit perceptual and cognitive processes are continually engaged in blending and segregating information from diverse sources". Crossmodal correspondences, result from the way the organism exposed to several stimuli that happen to be presented in different modalities at any given time considers which are likely to belong together [106].

The brain may combine information from different sense modalities to enhance the speed and accuracy of detection of objects and events, and the choice of appropriate responses. Generally-speaking, it appears that brains have been shaped to combine sensory cues coming from different senses when they occur close together in time or from similar locations in space [107], and the investigation of the rules governing this links has dominated the field of multisensory research [108].

Some practical example being studied are the correlation between certain musical timbres with particular smells [107], [109], shapes [110], and colours [102]; Visual shapes are matched to tactile hardness, brightness, and pitch [111], to pieces of music [112], tastes [113], smells [114], [115] and flavours [116], while colours are matched to temperatures [117], music [109], [118], [119], odours [120], angles [121], shapes [107], tastes [122], [123] and letters [124]. 


\subsection{Reading \& Processing Info}

Despite technological developments (e.g. noses and electronic tongues) [105], [122], from simultaneous measurements of human perception and physical concentration in vivo, texture - aroma and texture taste interactions are not always explained by physico-chemical mechanisms. Moreover aroma - taste interactions have been the subject of many studies already reviewed and are mainly explained by cognitive interactions even if in some case physico-chemical mechanisms may occur. Finally, few studies mentioned the impact of aroma and taste on texture perception. The aim of this review is to focus on the impact of aroma, taste and texture interactions on flavour perception. For each type of binary interactions (texture - aroma, aroma - texture, texture - taste, taste - texture, taste - aroma and aroma - taste, some stimuli are only perceived by the human senses while others are too complex for the instruments of analysis.

One of the most important functions of the nervous system is to process incoming information in such a way that appropriate mental and motor responses will occur. Figure 3 shows the somatic portion of the sensory system, which transmits sensory information from the receptors of the entire body surface and from some deep structures. Channelling and processing of information is called the integrative function of the nervous system. Thus, if a person places a hand on a hot stove, the desired instantaneous response is to lift the hand. And other associated responses follow, such as moving the entire body away from the stove, and perhaps even shouting with pain. Although, more than 99 per cent of all sensory information is discarded by the brain as irrelevant and unimportant, for instance, parts of the body that are in contact with clothing, as well as of the seat pressure when sitting and even the perpetual noise of our surroundings is usually relegated to the subconscious [125].

Memory is only a small fraction of even the most important sensory information that usually causes immediate motor response. But much of the information is stored for future control of motor activities and for use in the thinking processes. Storage occurs in the cerebral cortex, but even the basal regions of the brain and the spinal cord can store small amounts of information. Each time certain types of sensory signals pass through sequences of synapses ${ }^{2}$, these synapses become more capable of transmitting the same type of signal the next time, a process called facilitation. That signals generated within the brain itself can also cause transmission of impulses through the same sequences of synapses, even when the sensory input is not excited. This gives the person a perception of experiencing the original sensations, although the perceptions are only memories of the sensations [125].

Another characteristic of all sensory receptors is that they adapt either partially or completely to any constant stimulus after a period. That is, when a continuous sensory stimulus is applied, the receptor responds at a high impulse rate at first and then at a progressively slower rate until finally the rate of action potentials decreases to very few or often to none.

Subconscious activities of the body, feeding reflexes, such as salivation and licking of the lips in response to the taste of food, are controlled by areas in the medulla, pons, mesencephalon, amygdala, and hypothalamus.

The input to the nervous system is provided by sensory receptors that detect such sensory stimuli as touch, sound, light, pain, cold, and warmth. (1) mechanoreceptors, which detect mechanical compression or stretching of the receptor or of tissues adjacent to the receptor; (2) thermoreceptors, which detect changes in temperature, some receptors detecting cold and others warmth; (3) nociceptors (pain receptors), which detect damage occurring in the tissues, whether physical damage or chemical damage; (4) electromagnetic receptors, which detect light on the retina of the eye; and (5) chemoreceptors, which detect taste in the mouth, smell in the nose, oxygen level in the arterial blood, osmolality of the body fluids, carbon dioxide concentration, and perhaps other factors that make up the chemistry of the body [125].

Each nerve tract terminates at a specific point in the central nervous system, and the type of sensation felt when a nerve fiber is stimulated is determined by the point in the nervous system to which 
the fiber leads. Similarly, fibers from the retina of the eye terminate in the vision areas of the brain, fibers from the ear terminate in the auditory areas of the brain, and temperature fibers terminate in the temperature areas. Respectively, each type of receptor is highly sensitive to one type of stimulus for which it is designed and yet is almost nonresponsive to other types of sensory stimuli [125].

\subsubsection{Touch}

Touch is the oldest, most primitive and sensitive sense of our organs. Tactile cues concern the mouthfeel, texture, temperature, and trigeminal sensations.

The sense of touch is mediated by the somatosensory system that allows to perceive pressure and texture (mechanoreceptors), temperature (thermoreceptors), pain (nociceptors) and position and movement of muscles and ligaments (proprioceptors) [105].

The trigeminal system belongs to the chemosensory system, next to olfaction and gustation. As smell and taste, trigeminal sensations arise from the interactions of chemicals with specific chemoreceptors. Ethanol, vanillin, menthol, carbon dioxide and capsaicin are some examples of stimuli to trigeminal system. The olfactory and the trigeminal system are intimately connected and interact on several levels. Some sensations that are perceived as spicy, astringent, burning, metallic, refreshing, numbness or carbonation, are trigeminal and they should not be confused with tastes [105], [125].

JowITT (1974) has defined mouthfeel as: 'those textural attributes of a food or beverage responsible for producing characteristic tactile sensations on the surfaces of the oral cavity'. Typical mouthfeel characterisics, then, include sticky, astringent, stinging, oily and so on. The oral texture (in particular, the viscosity) of food and drink turns out to exert a significant influence on the multisensory perception of flavour [120], [127]. Preferences for textural and mouthfeel characteristics can be innate or learned [128]. Tactile cues can enhance food perception, for example the touch, allows predicting the crispness of a food in the mouth. However visual textures can induce wrong expectations [129]. More specific to the Design, tactile cues influence through the material and temperature of the cutlery or table cloth, by the weight of the glass or the wine bottle, greater weight corresponds to higher value and better quality [64] or through the texture of the food or even the dish. It was shown that the roughness / softness of the food influences the perception of the acid taste, increasing it when the food is rough. Acquiring additional evidence concerning the impact of felt texture on the experience of food is clearly of growing relevance, given the increasing number of chefs, artists, and designers interested in utilizing different materials and/or textures in their plateware, cutlery, even the texture of the restaurant seat itself [130], [131]. Also, the oral somatosensory experience of texture is altered by the prior visual perception of its colour

FilipPo Tommaso MaRinetTI (1876-1944), back in the 1930's organized tactile dinner parties in which the guests were encouraged to wear pyjamas made of (or covered by) differently textured materials such as cork, sponge, sandpaper and/or felt and to eat without the aid of knives and forks to enhance the tactile sensations and maximally stimulate the senses of the diners [130]. Marinetti was, then, perhaps one of the first to think creatively about the importance of touch and tactile stimulation to the act of eating. The importance of touch can also explain the fact that many people around the world eat without the aid of cutlery, and some of them claim their food to be tastier when eaten in this way [132].

\subsubsection{Smell}

In regard to gastronomic delights it is safe to say that at least two-thirds of our enjoyment is due to the sense of smell [133]. In fact, only around $15-20 \%$ overall is taste, the other $80-85 \%$ is retronasal olfaction [134]. 
In short, smell is the ability to detect vaporized chemical molecules (usually of low molecular mass). The sense of smell is bidirectional or bimodal and the way odors are perceived changes according to the direction of the airflow [135].

The receptor cells for the smell sensation are the olfactory cells which are bipolar nerve cells are located in the nasal cavity (see figure 4 and 5). There are about 100 million of these cells in the olfactory epithelium interspersed. This is the only site in the body where the central nervous system is in direct contact with the outer surface. The number of activated cells seems to depend on the intensity of the odour. Stimulation of the olfactory system begins when odorant molecules are detected by this cells, then olfactory information is transmitted to the olfactory bulb which, in turn, transfers this information towards multiple hiaher cortical reaions collectivelv referred to as the olfactory cortex [125].

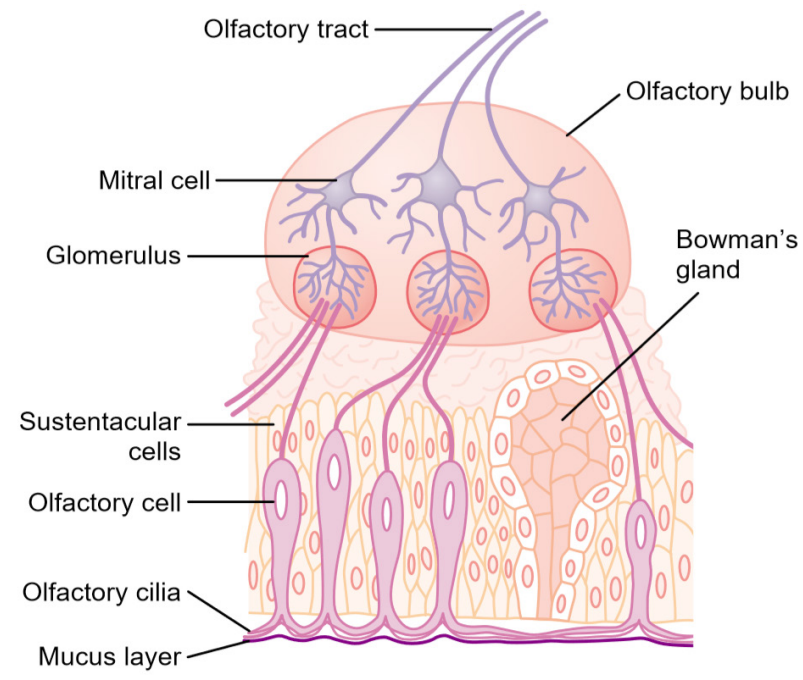

FIGURE 4. Organization of the olfactory membrane and olfactory bulb, and connections to the olfactory tract, Guyton and Hall (2006)

The odorant molecules can reach the epithelium by two pathwas: via the nose (orthonasal olfaction) and via the mouth (retronasal olfaction). Odorants perceived by the orthonasal pathway originate from the external world whereas odorants perceived retronasally emanate from food or drink (aroma compounds) [105].

Only volatile substances that can be sniffed into the nostrils can be smelled, also the stimulating substances must be at least slightly water soluble so that they can pass through the mucus to reach the olfactory cilia, and it is helpful for the substance to be at least slightly lipid soluble, presumably because lipid constituents of the cilium itself are a weak barrier to non-lipid-soluble odorants. Odorants may be recognized by multiple olfactory receptors (OR), and one OR may recognize multiple odorants. However, the way a receptor recognize an odorant still remains poorly understood and further studies are necessary to investigate the physicochemical laws that govern OR-ligand interactions (see figure 5) [105].

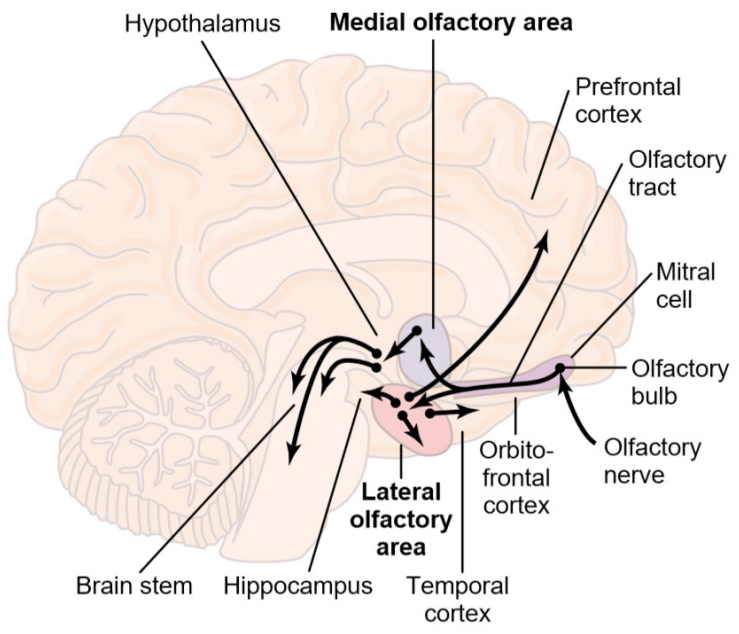

FIGURE 5. Neural connections of the olfactory system, Guyton and Hall (2006) 
The neural processing of the information about a certain odor is done through the elaboration of "maps" in the nasal bulb and in other cerebral structures. A particular odor induces action potentials in specific olfactory receptor cells. These potentials give rise to a "spatial map" of the pattern of activated cells, which is characteristic of this odor. The transposition of this "map" to olfactory structures in the brain (including memory) triggers the response(s) to that odor [105].

The olfactory receptors adapt about 50 per cent in the first second or so after stimulation. Thereafter, they adapt very little and very slowly. It is known, from experience, that smell sensations adapt almost to extinction within a minute or so after entering a strongly odorous atmosphere.

There is a constant misunderstanding associated to Smell and Odour. Odours delivered via nostrils are differently processed and perceived from those delivered via the mouth. Most importantly, the two modes of action have a differential impact on eating and drinking.

Smell and flavour have a huge impact on the perception of the world and this fact is used by commercial companies. For example, car manufactures inject leather smell into a car to make it appear top quality, coffee companies often inject roast coffee aromas into the packages so when people open them they feel a freshly grounded coffee aroma [109]. This kind of knowledge is invaluable to cuisine, some plants start losing aroma molecules as soon as they are picked, and on certain substances adding a specific aroma may enhance it [6], ultimately it is the combination between volatile molecules which allow the modern chef to create extremely complex dishes. A simple example consists in adding a drop of a particular hexanol to a parsley purée, it brings an extraordinary freshness to it [134]. Hexanols are a group of volatile compound that convey the green notes in most food, the heavier molecules in this group represent odours such as pear and banana, and the lighter for green apple and freshly cut grass [136]. In cooking there is no interest in separating these compounds, but deep understanding might lead to wonderful new creations [134].

Droplets of flavour may hold the key to enhance a certain food, huge but quick bursts of flavour help increasing the experience. Depending on the type of food chefs devise the best way to encapsulate it, being a fat soluble volatile it will be better eaten with a watery solution for an easier passage to the nose and viceversa [134], [136].

Years of studying have permitted to reproduce aromas from all sorts of ingredients, take for example vanillin the main volatile compound in vanilla which can obviously be extracted from the bean, but can also be synthetized from rice or lignin (wood) just by isolating the main molecules which form vanillin [10].

Some theories defend that ingredients having identical volatile molecules can be positively paired, for the professional chef it means that if liver and jasmine have similar flavour molecules profile can form a good food pairing, although this is not always applicable [137], [138].

The intensity of aroma decreased with increasing consistency of the consumed food. Also, small bite sizes and longer duration of oral processing tend to increase aroma release in the mouth, which may result in higher or faster satiation.

Odors can unconsciously modify behavior, generate emotions, or evoke past situations [63]. Smell is probably the sensory modality most difficult to verbalize [63].

There appears to be an association between colour and olfaction [124]. For example, in wine tasting the sensory and cognitive processes are particularly influenced by the wine colour.

Crossmodal correspondences related to smell were also identified [2]. Also, another study revealed that the lemon and pepper odors were significantly associated with the angular shape, whereas the raspberry and vanilla odors were significantly associated with the rounded one instead [139]. 


\subsubsection{Sight}

The colour, shape, exterior texture, brightness, clarity and transparency stand out as the most relevant characteristics for the perception of a food through vision. The first contact with food is through vision, and it contributes to the acceptance of it. Sight is the first sense responsible for food approval and colour is the characteristic that most contributes to the creation of food related expectations [140].

Visual perception is the result of light stimulation of photosensitive cells in the retina. Light passes through the lens of the eye (crystalline) and is focused on the retina, where cells (cones - related to vision "in colour" when the luminosity is high, and rods - related to "black-and-white" vision in low light) convert light into electrical / neural impulses, which are sent to the brain through the optic nerve. The brain receives these impulses, processes them and interprets them as images of the objects seen [141]. The human eye can detect almost all gradations of colours when only red, green, and blue monochromatic lights are appropriately mixed in different combinations. White is a combination of all the wavelengths of the spectrum (see figure 6).

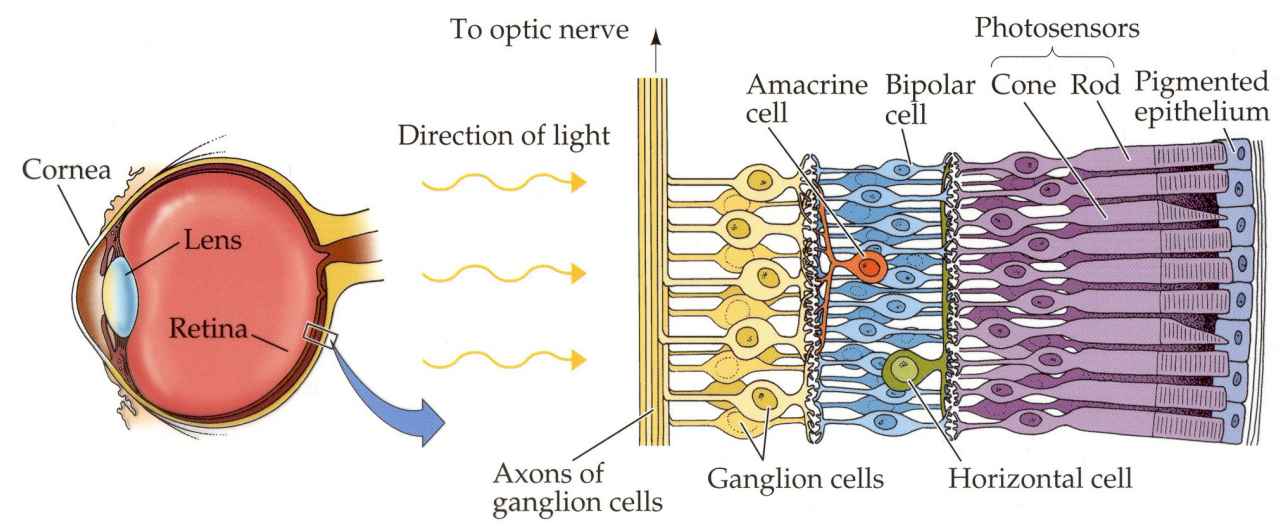

FIGURE 6. Photoreceptor cells: rods and cones, Lopes (2013)

Majority of sight crossmodal correspondence approaches are about colours of food itself,. Similarly, the perception of aroma and flavour are also affected by both the hue (i.e., red, yellow, green, etc.) and the intensity, or saturation, of the colour of the food and drink.

The addition of yellow colouring to a sweet solution, decreased the taste detection threshold significantly, while the addition of green colouring increased it (interestingly red had no effect). The addition of red colouring reduced the threshold to a bitter-tasting solution, while the addition of yellow and green colouring had no such effect. Remarkably, taste detention threshold for the salt solutions were unaffected by colouring, perhaps because salty food comes in so many colours. The participants reported that a cherry-flavoured drink tasted of lemon/ lime when coloured green. Detected an orange flavour when the drink was coloured orange. Interestingly, the manipulation of the intensity of the colour added to a foodstuff does not, however, appear to have such a clear-cut effect on people's judgements of flavour (or, for that matter, taste) intensity.

One important aspect that requires further research is to understand the nature of the colour effect on flavours perception, particularly if it predominantly cognitive and based on previous experiences, or results from multisensory integration effects that appear to govern oral-somatosensory-gustatory-orthonasal-olfactory interactions (i.e., if it depends on an expectancy set-up by the presence of a particular colour in the substrate).

The influence of the glassware and plateware on the perception of food is also an important aspect to consider [142]. Research conducted at the Alicía Foundation in Spain, exactly the same frozen strawberry mousse was rated as tasting 10\% sweeter and 15\% more flavourful, and was liked significantly more, when eaten from a white plate rather than from a black plate instead [8].

This empirical question is particularly relevant given that the visual appearance of most foods and drinks does not include only a single colour. Instead, it involves various visual characteristics with different 
ranges of hue, brightness, and saturation. Therefore, it can be hypothesized that multiple colour cues, if chosen appropriately, may provide more information when inferring a specific taste quality [143], [144].

He visual shape or format also influence taster perception, as sweet tastes have been found to be associated with roundedness, and bitterness is associated with angularity [145], as angularity is unpleasant [99]. When food is served in a rounder shape container, people often rate it as tasting sweeter than when exactly the same food is presented in a more angular form instead [8], [9].

Dining in the dark experiences exclude visual clues from food perception. When the lights are on, visual cues dominate the dinner and many sensory nuances are missed, but in an experience like this they do not contribute to expectancy or perception [146]. Also, diners can find difficult to distinguish between flavours in the absence of visual cues. First, because normally sighted individuals typically have a great deal of stored knowledge concerning the appearance properties of foods and beverages. This means that once they have recognised it via their other senses, they often can't help but create in their minds a potentially vivid mental image of what the food or beverage actually looks like. They may even retrieve information concerning how it has been cooked, and how much they like it. This multisensory mental image might then serve as an input and in some sense feed the cognitive eating process. Despite the fact that a number of researchers have addressed this question over the years, the available evidence is still rather mixed: while some researchers have documented superior olfactory and/or gustatory abilities in the blind, others have failed to observe any such difference [147].

Furthermore, it is important to consider the colour of the lighting in the restaurant. Indeed, the temperature, intensity and type of illumination can all be expected to exert some influence on the perceived colour of the plate, the food placed on it, and on the atmosphere, and hence on the flavour of the food itself, not to mention on the mood of the guests [130]. There are some restaurants where the diner can change the atmosphere in their dining space, as for example Pod restaurant in Philadelphia, to convey a particular multisensory mood or ambiance. The effect of changing the ambient illumination might be expected to have an even bigger effect on people's taste/flavour perception if the apparent colour of the food/drink also change. Lowering the ambient lighting level might also be used to help mask the colours (and hence taste) of any food that happens to be, for whatever reason, visually less-appealing [88]. For example, it was found that wine (but presumably also other food and beverage products) tastes sweeter when consumed under red ambient lighting, than under blue, green, or white lighting. [88].

Cross-cultural differences and individual differences can also be factor influencing diner's sensitivity to visual aesthetics. There is no reason, a priori, why one should expect that what looks nice to a North American diner would necessarily appeal equally to an Italian or Japanese diner [85], [130].

\subsubsection{Audition}

According to Spence (2016) hearing is "the forgotten flavour sense". Although any component in modernist restaurants is not there by chance, light frequency, crockery and furniture are some examples, and sound is always in the background and of the type of music playing can be carefully chosen depending on what sensation the chef wants to transmit [148].

The human ear works in frequencies between $20 \mathrm{~Hz}-20000 \mathrm{~Hz}$ and is quite sensitive to air pressure. Amplitude or intensity is related to the magnitude of the movements produced. A sound wave produces compression and rarefaction of the air, the molecules of which vibrate around their mean positions. The extent of the pressure variation has a subjective correlation to loudness. The frequency (measured in $\mathrm{Hz}$ ), the number of waves passing a point in a second, has a subjective correlation to pitch. 


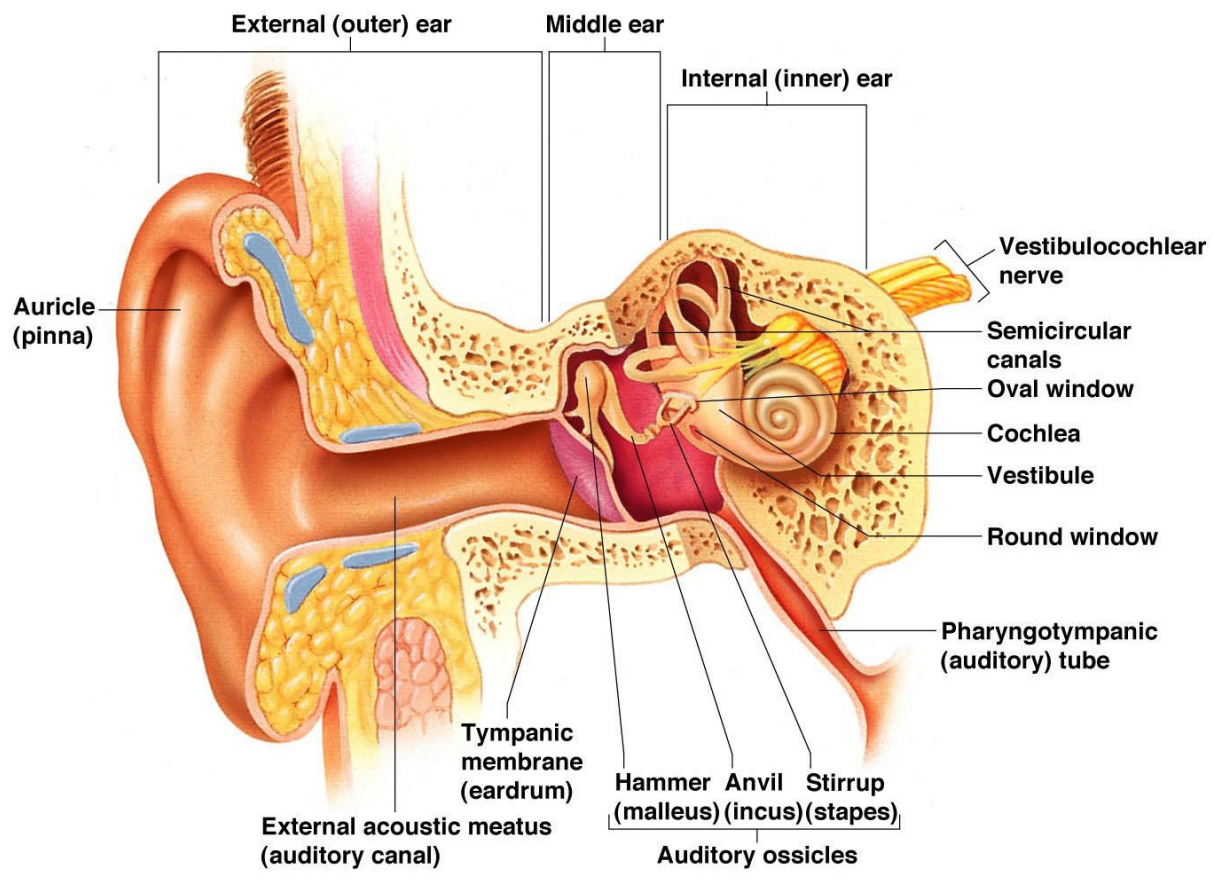

FIGURE 7. The external, middle and inner ears, Guyton and Hall (2006)

Sound waves traveling down the auditory canal collide with the tympanic membrane, an ultra-sensitive, translucent and slightly cone-shaped membrane of connective tissue that is the boundary between the external and middle ear. Sound waves make it vibrate so it can pass those vibrations, to amplify those sound waves so that they become stronger than when they enter the inner ear, because there the space is composed by fluid and not through air (see figure 7) [125].

An evidence from a number of recent laboratory-based studies demonstrates that loud background, noise can indeed suppress our ability to taste food and drink [149]. A study published in 2011 found that loud back ground noises suppress saltiness, sweetness and overall enjoyment of food, that is airplane passengers never enjoy food in the same way during the flight [149]. Spence pointed out: "Have you ever noticed how many people ask for a bloody mary or tomato juice from the drinks trolley on airplanes? The air stewards have, and when you ask the people who order, they tell you that they rarely order such a drink at any other time." He believes this happens because umami taste may be immune to noise suppression, if his hypothesis is proved this may be a large step for making flight meals enjoyable, they should concentrate in ingredients full of umami like tomatoes, mushrooms, parmesan and cured meats [149].

It was proved that the sound heard while eating highly influences perception [138]. Many studies show the modal dependence between the flavour perceived and the ambient music. For Charles Spence, music functions as a flavouring that can contribute to the improvement or, just, alteration of the gastronomic perception [119].

However, the physical interactions with food and drink while biting, chewing, masticating, sucking, and slurping all generate potentially informative auditory cues that may influence our perception of the textural properties of the food, and even the oral-somatosensory perception of mouthfeel. It can be argued that the crunchy, crackly, crispy, carbonated, creamy, and squeaky sounds of food and drink consumption all have value to the consumer [8].

Some studies of the influence of noise on perception of food were made. Ferber and Cabanac analyzed the effect of noise $(70 / 90 \mathrm{~dB})$ on taste and results show an effect on hedonic responses to sweet solutions, but not to salty ones; Woods et al. studied the effect of noise (75-85 dB) on pringles and cheese and the results were significance for sweet and salty tastes; Woods et al. also worked with 75-85 dB (noise) applied this time to rice cakes with added flavours and concluded that higher crispness was perceived for higher noise; Seo et al. studied the effect of 70/82 dB (voice or party noise) on odours and the results showed a more pronounced effect on the reduction of odour for verbal noise than for party noise [8]. 
It was also verified that the sound of some words is more appealing to certain flavours than others. Köhler asked participants which of the two shapes (a) and (b) should be called 'Maluma' and which should be called 'Takete'. He observed that most people would instinctively call the spiky shape Takete and the rounded shape Maluma; Ramachandran and Hubbard (2001) had participants choose which of the two shapes (c) and (d) should be called 'Bouba' and which 'Kiki'. 90\% of the Western participants apparently agreed that 'Bouba' would be the rounded shape and 'Kiki' the spiky one (see figure 9). There was a strong preference for "bouba" to be associated with a curvy, rounded shape, and for "takete" to be paired with a sharp, angular one. The same result has now been demonstrated in a wide variety of cultures [114]. The impact of the name can help to improve brand assignment by taking into account the type of product [110]. Studies, in the field of psychology and neuroscience, suggest that a food can be perceived as being sweet just because it has been given the name: rose flower [150].

Figure 9. 'Bouba' and 'Kiki' experiment, Hanson-Vaux, Crisinel and Spence, (2013)

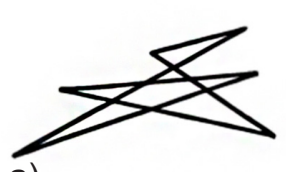

a)
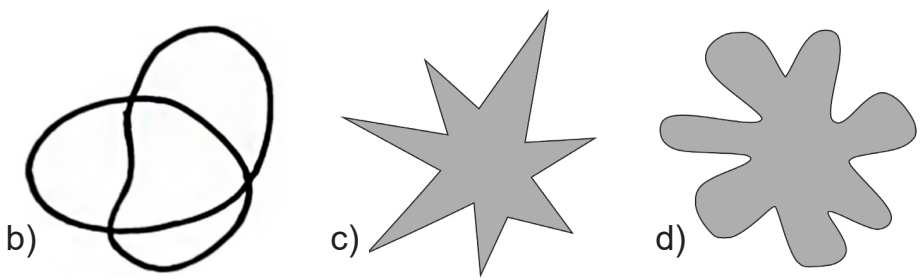

Sound is also very important to the perception of crispy and crunchy foods such as chips, cereals, biscuits and vegetables [148]. For this reason, in the 80's Kellogg's tried to trademark the sound of the crackling of their cornflakes.

Also, the package of cereals and crisps are noisy, this was developed to createa context that conveys the idea of crispiness [9]. The consumer will prefer potatoes packaged in a package that makes more noise because it will be associated with the fact that potatoes are crunchy. It is possible to tell a lot about the texture of a food-crispy, crunchy, and crackly — from the mastication sounds heard while biting and chewing.

An experiment conducted by Charles Spence and Heston Blumenthal with oysters showed that sound context is one of the main pieces to congruent perceptions. Subjects were given identical samples of oyster, they tasted it hearing farm sounds (sheep and chickens mostly) and sea sound (the waves and seagulls) they perceived the oyster saltier and fresher hearing the sea sounds [149].

Another experiment involving bacon ice cream showed that a specific flavour can be enhanced using sound as well, subjects were given the same sample of bacon ice cream and heard to farm sounds or the sound of sizzling bacon, the bacon flavour was accentuated with the second one [149].

Another experiment was designated to investigate the consequences of manipulating low and high pitch as background sound in an auditory and the influence of stimuli it has on the taste of food. The subjects were asked to evaluate pieces of cinder toffee while listening to the designated soundtracks presented in random order. The low pitch track was designated to be more cross-modal congruent with a bitter taste and the subjects could feel coffee notes in it, in the other hand the higher pitch sounds made the participants feel the same toffee more congruent to a sweet taste [109]. CRISINEL, (2012), has demonstrated that people consistently match sweet tastes with high pitched notes on the piano, whereas bitter-tasting foods (such as coffee and dark chocolate) and more commonly matched with lower pitched notes played on brass and woodwind instruments instead [149].

It has also been found that people buy more expensive wine if the ambient music is classical and not pop music. Wine cellars and shops started playing classical music rather than pop because it encourages costumers to buy higher-priced bottles, the classical music creates a context of high standards and finesse (as it is perceived by the general public). For restaurants or bars, it was discovered that just by playing fast loud music it is possible to increase the number of sips costumer take, shortening the time of drinking one drink and probably contributing to selling more [109]. It is important to bear in mind the congruency between the restaurant concept, the clientele, and the type of music that is played [151]. 
Playing faster music has been shown to result in people eating and drinking more rapidly. In the slow music condition, the diners spent more than 10 min longer eating. In other words, simply by slowing down the music it was possible to increase the gross margin at the restaurant by almost $15 \%$. It can affect everything from how long customers choose to stay in a restaurant through to how much they end up eating, from how rapidly they bring the fork or spoon up to their mouths through to how much they end up spending, and from how ethnic they rate the di sh through to how acceptable they rate the overall multisensory dining experience [8].

"You sell the sizzle not the steak." [152]. this statement means that it is the sizzle sound that helps set up expectations about the sensory qualities of the steak that is about to come [153]. It is the setting of the expectations (both sensory and hedonic) that anchor the subsequent tasting experiences [154]. Reproductive sounds are associated with food preparation, such as the popping of corn, perking of coffee, simmering of liquids, bubbling of syrups, broiling of meats, frying of eggs, and cracking of nuts. Sounds can give cues about the likely temperature, level and type of carbonation, and possibly even viscosity of a drink [155]. Although most people do not realize it, sound plays a very important role in our perception of food and flavour perception [151]. The last decade has seen an explosive growth of interest in modifying and enhancing the sounds of food and beverage preparation in order to set better taste and flavour expectations in the mind of the consumer. Sonic seasoning can be used to draw a taster's attention to some aspect of their tasting experience, and hence make it more salient. The music can make the food and drink appear more valuable. It certainly has an impact on how much people end up consuming, and even on how much they spend. Music can be chosen to arouse or relax, and even to increase the amount of time spent in a given venue. Some restaurant chains know this, and carefully pick the music playing in their stores [154].

\subsubsection{Taste}

Taste is associated with the perception of non-volatile substances that, when dissolved in water, fat or saliva, are detected by taste-receiving cells in the taste buds located mainly on the tongue, but also in other parts of the body, such as the trachea, stomach, bile or intestines [125]. Only the mouth will be considered in the following text.

Taste buds are the main taste organ, having between 10 to 50 sensory cells, in a form of a capsule that is shaped like a flower bud, that are in turn connected to many different nerve fibers, The taste buds are located in the walls and grooves of the papillae. Adults have between 2,000 and 4,000 taste buds in total, spread in the back of the throat, epiglottis, the nasal cavity, and even in the upper part of the esophagus [156].

There is a stimuli from a substance attaching to its specific receptor - G-Protein Coupled Receptors (GPCR) for sweet, bitter and umami, and Taste Receptor Protein Channel (TRP channel) for salty (caused mainly by $\mathrm{NaCl}$ ) and sour (caused by protons) - signal transduction takes place and a chain reaction is followed, ending in activation of neural impulse and signals to the brain [156].

Taste lies on the five already discovered groups of receptors existing in the mouth: sweet, sour, salty, bitter and umami [157], and each one of these groups have specialized receptors [156]. For sweet only two were discovered, however more than thirty specialized bitter receptors were encountered, all these constitute specialized alarms in the tongue warning for possible poisons. The regions of the tongue specialized in each taste are now considered a myth [8]. All types of receptors exist in all areas of the tongue and all tastes can be perceived within all its area, but that each individual has different concentrations of specific receptors, meaning that different individuals do not perceive a taste with the same intensity in every area of the tongue. To understand better the complexity that is the sense of taste, taste buds in tongue have a lifespan between 10-14 days and each time they change new connections are made with the brain and there is no guarantee that they will be exactly the same and although people may not be aware of it, the sense of taste is constantly changing [158]. 
2 The synapse is the junction point from one neuron to the next, they determine nervous signals will spread through the nervous system, normally passes only in the forward direction (from the axon of a preceding neuron to dendrites on cell membranes of subsequent neurons).

"Nerve impulses," are created through a succession of neurons, one after another [125]. the directions that the

Umami was the last basic taste to be identified. This discovery is the consequence the work of professor Ikeda at the University of Tokyo in 1909. Umami refers to a savoury sensation, is produced mainly by monosodium glutamate (MSG) [125]. It can be found in many foods including human mother's milk, fish, meat, milk, soy sauce, tomatoes and some vegetables including mushrooms. Ripe tomatoes, meat and cheese all contain significant amounts of MSG. Umami can also be enhanced by the presence of other molecules such as ribonucleotides present in yeast extracts and fermented dried tuna fish sold in Japan as bonito and used to make the soup stock called dashi [159].

Some new tastes, namely Fatty, Alkaline, Metallic and Water-like, have been studied but are still waiting further studies for their recognition.

The relation between taste and human crossmodal correspondence is mainly focused on colour psychology. Sweet, for example, tends to be associated with colours such as red or pink, sour with yellow or green, salty with white or blue, and bitter with black or other dark colours such as brown or purple [113]. Possible reasons for such associations are some specific or general food memory prompted by the colour, or indeed even hue, that give rise to a particular assignment to taste [144], rather than the colour itself. For example, the colour pink may prompt the concept of candyfloss, and probably it is this association, rather than the colour itself, that is thought of as sweet (not all of the authors though believe that correspondences are necessarily grounded in specific experiences of environmental objects that possess both features) [124].

Temperature can be an important variable in taste perception. In general, sweetness increases with heating and, notably, the influence of temperature decreases at higher concentration of the stimuli. The bitterness of caffeine is decreased by cooling, whereas for quinine, the paradigm compound for bitter taste, it was reported that taste threshold increases with heating. While monosodium glutamate (MSG), which is described as a salty-dependent component, peaked at $10-15^{\circ} \mathrm{C}$, due an increasing temperature might represent an umami-dependent component, as maximum at $30^{\circ} \mathrm{C}$. These observations may explain why ham appears to taste saltier at cold temperatures and more savoury at high temperatures [117].

It is known that capsaicin suppresses human responses to sweet, bitter and umami but not to sour and salty stimuli. Another 'hot' compound, capsicum oleoresin, decreases the responses to acid, bitter and sweet compounds, whereas piperine has also an effect on responses to salt [105].

At the moment taste is focused in the five basic tastes although there are plenty of variances induced by numerous characteristics and features of food matrix, environment, materials involved, sound, temperatures, among other inputs that only food design coupled with gastrophysics can really understand and read this involvement in order to produce a "perfect meal". All these sensations experienced while eating are crucial and should have a tremendous impact on whether foods will be accepted or rejected. For adults, the changes in life may directly affect food choices and thus modify flavour preferences. The plasticity of the brain allows human beings to be uniquely adaptable to their environment [122]. 


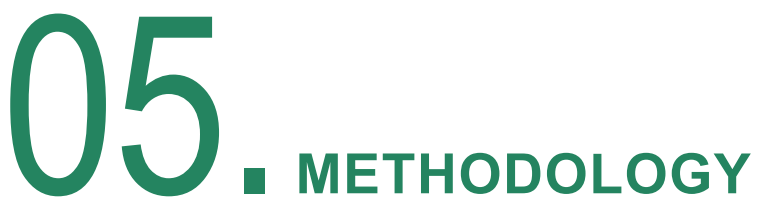

In this chapter the explanation of the choice of the topic of the dissertation will be made, and the planning and alignment of the proposed research, the work done and its instruments, the methodologies used, and the data collection and analysis will be described.

The central question: "How can food design contribute to the sensory perception of a fine dining menu?", was defined according to the methodologies described in GIL (2008), through direct observations and participation in professional life [160], by specialized bibliographic research, through contact and relationship with specialists, and also using previous research guidelines by other authors [161]. It was also considered that the research subject should fit into some of the topics of study of the master's degree in Gastronomic Sciences and into the lines of research and action of the respective supervisors. This central issue not only contributed to define the theme of the dissertation, but also served as a reference throughout the work developed. Several meetings with the supervisors allowed to define methodological and chronological plans, structuring this dissertation [160], [162].

The research work described has as object of study a menu composed of five dishes, each one focused in one of the five human senses.

In general, the theory of Positivism is applied, which holds that only scientific knowledge is valid and genuine. "According to the positivists it can only be said that a theory is correct if it has been proved by valid scientific methods" [160]. However, it deals with an investigation in food design, entering a field still in scientific development [4]. The methodology proposed to reach the objectives outlined and answer the questions of investigations is of mixed exploratory character, using interventionist and non-interventionist methods of qualitative character.

In the first phase of the work, a literature review was developed through the collection, selection, analysis and critical synthesis of relevant documentation in the following research areas [160]: food design, sensory perception, neurosciences, gastrophysics, food science and natural products chemistry. Research was carried out mainly before the work developed, but also during and after. These fields have been defined in the meetings mentioned above as being relevant to the work in question. The objectives of a literature review are: state of the art determination, theoretical, empirical and historical review.

Sources based on books, scientific journals, peer-reviewed journals, articles of scientific circulation, single publications, among others allowed the preparation of a provisional scheme for further investigation and definition of each dish to be used in the tests in order to obtain adequate results with the least possible outside influence. Several meetings at La Masía (I\&R) of the restaurant El Celler de Can Roca allowed to identify and understand relevant parameters to consider in the study.

It is important to mention that the design process models offer proposals for the systematization of procedures, actions, and of the different influences and constraints that arise from the creative activity, represented as applied creativity. The application of several methods, not just one in particular, allows amplifying the possibilities of analysis and obtaining answers to the problem proposed in the research, as well as a better applicability to the different characteristics of each dish. 
The design of the menu resulted in a symbiosis of Design with current and cutting-edge cooking techniques. There was an exploration of other areas such as product design in the production of porcelain pieces, statistics, colour psychology, thermography and magnetism, depending on the characteristics of each dish. The diversity of these characteristics necessarily forced resorting to a wide range of techniques, also involving the concept of transdisciplinarity. In order to make the description more intelligible, this information will be extensively covered in the description of each dish.

For the study of the sense of touch, the technique of Empiricism was applied, which states that experiences are the foundation of ideas. This phenomenological methodology, which is based on the lived experiences, evidencing the preponderance of the individual, also characterizes the creative cooking process. Through a Focus Group, a qualitative research technique used to analyse subjective topics and that involves discussion and sharing of opinions in a moderate way, an external evaluation of the dish was carried out. Focus group was held with 6 Chefs from the Ritz Four Seasons Hotel, with the purpose of acquiring relevant information considering the central issue and the objectives. The techniques used in the development of the dish involve gelatinization, gelling, dehydration, cold infusion, use of liquid nitrogen, thickening, emulsification, pressurizing, protein denaturation, inversion of phases, frying, among other techniques mentioned throughout the corresponding chapter. As a design technique, monochrome should be highlighted.

For the study of the sense of smell, the method of discovery was applied, integrated in Empiricism theory, as it is associated to the production of new knowledge and new results. The study involved sensory analysis tests, with 33 employees of the restaurant El Celler de Can Roca, as data collection technique. Results were subjected to a statistical analysis using the IBM SPSS Statistic grad Pack 24 and XLstatics programs. Several tests were performed for data processing: Tukey test, Principal Component Analysis (PCA), Friedman test and Wilcoxon Signed Rank test. The final results obtained were applied in the design of a porcelain piece in Vista Alegre. As cooking techniques, emulsion, foaming, stabilizing, smoking, dehydration, grilling, gelling were applied. A T360 Thermal Flir camera was used to obtain thermal photographs. For the study of hearing the theory of Rationalism was applied, with a research approach by the deductive method using the logic of science that aims to predict and control results. From a bibliographic investigation and the collection of information resulting from scientific studies on the influence of hearing on food perception, it was possible to plan the dish presented, Sounds of the Forest. The cooking techniques applied were: sous vide, tenderization of meat, protein denaturation, emulsion, bleaching, emulsion with vegetable protein, chocolate tempering, ultrasonic infusion, reduced pressure distillation, frying.

For the study of the sense of sight the phenomenological methodology and the inductive method were applied, characterized by the researcher being part of the investigation. It aims to understand, interpret and directly describe the experience as perceived. Through the process of Double Diamond Design and techniques of visual composition it was possible to plan the dish in question. The cooking techniques applied were: protein denaturation, grilling and gelling, among others. As for the design, the optical illusion, double reading of the visual composition and the movement stand out. The magnetism and spectrum of UV light, and their influence on fluorescence were also exploited techniques to achieve the for the desired objectives.

For the last dish, associated to the sense of taste, the deductive methodology was applied in which the researcher was separated from the investigation and his research was mostly result of bibliographic survey. The cooking techniques applied were: water crystallization, freezing, vacuum impregnation, carbonation. For the design of this dish colour psychology and crossmodal correspondence have been used.

The internships represent an approach of a qualitative nature which allows acuire knowledge, register and analyse the work of recognized chefs and acquire new skills. These have been applied in the creative process, converging dimensions of personal, contextual and social order.

The experimental design differed according to the proposal for each dish and its characteristics, 
however, the procedures developed included several common phases: (1) choosing the appropriate analytical methodology for each problem; (2) selection of suitable ingredients; (3) sample preparation; (4) quantitative and / or qualitative measurement. 


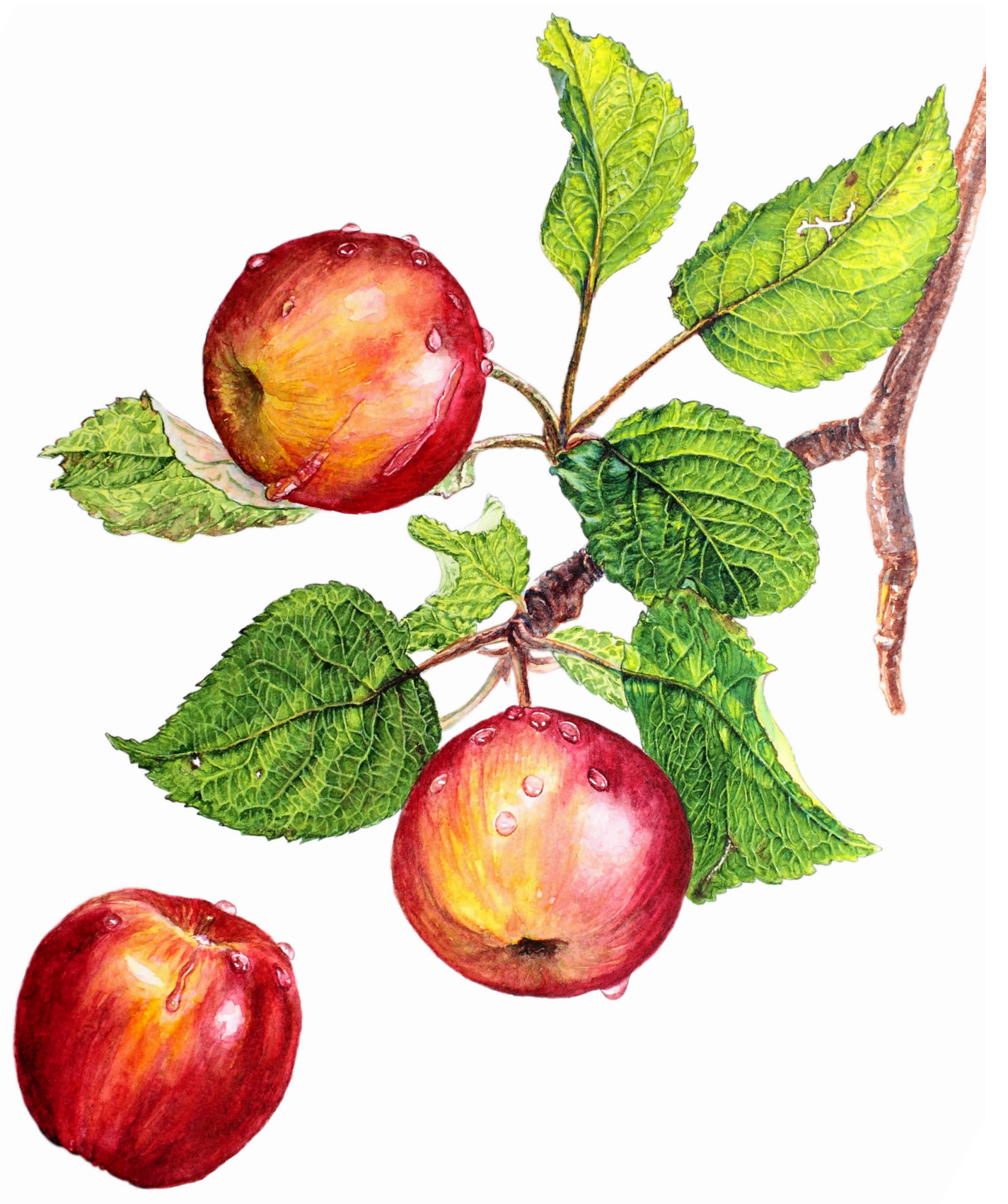

ILLUSTRATION | Natalia Maksakova 


\section{INSTERNSHIPS REPORTS}

\subsection{L'AIR DU TEMPS}

\subsubsection{Introduction and objectives}

With the purpose of acquiring as many knowledges as possible, as well as opportunities to contact with the work of chefs whose work reflects unique and important aproaches to cooking, an internship at the fine dining restaurant, L'Air du Temps took place in the context of this dissertation. It was considered that this experience related to food production, equipment, techniques, methods of work, technology and so many other aspects that characterize the work developed at a two-star Michelin restaurant with a science-based methodology of work, were essential to design the work described in this dissertation.

This two Michelin stared restaurant follows an approach based on sustainability, zero-waste and natureIt is situated in the countryside, having five hectares of agricultural production that mainly supplies the food served to diners. This is also coherent and very inspiring for the development of the menu described in this dissertation inspired in forest, hoods and nature. Besides the Executive Chef Sang Hoon Degeimbre adopted a molecular gastronomy approach to his own professional cuisine. Equally important, he has been working on the food design field in partnerships with some Design Studios in Belgium, as well as collaborating in this area with Universities in the same country. The three months duration of this internship allowed to contact several departments and kitchen sections of this restaurant, from gardening (growing crops, harvesting, watering, sowing and reaping) to pastry, garnish, meat and fish sections, but also the fermentation, preparation of mise-en-place and plating dishes sections. Some experience was also acquired at the innovation and development department, where design concepts were taken in account while creating new dishes.

The main objectives of this internship were to learn on the job, contact with the company's policy and methodology and improve knowledge acquired at the MSc in Gastronomical Sciences. Also, the possibility of using a set of new techniques, would allow to select and apply those relevant for the work described in this dissertation.

\subsubsection{Chef \& Restaurant}

Chef Sang-Hoon Degeimbre was born in South Korea and at five years old was adopted by a Belgian family. After starting pharmacy studies at the university, decided to enroll in a hotel school in Namur, followed by a school of butchery, before becoming a sommelier. As a sommelier, he had to work on his olfactory and gustatory sensibility, to detect nuances, balances between sugar and acidity and consider the details of each wine and pair it with food. Today, he uses that background experience to design dishes. 
FIgURE 10. Restaurant front door (left);

Gardening House (right); Rui Mota, 2016
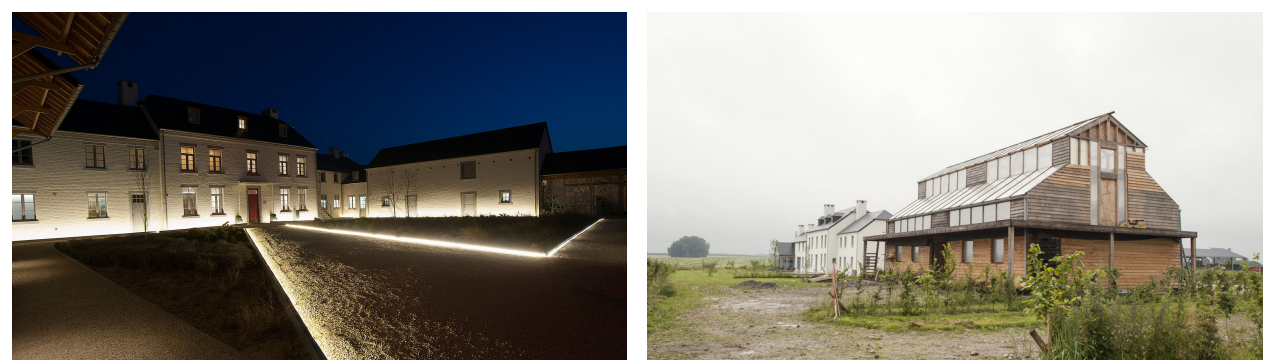

"COOKING WITHOUT ANY TRAINING MEANS THAT YOU HAVE NO BOUNDARIES. WHEN YOU ARE AT SCHOOL, YOU LEARN TO FOLLOW A RIGHT WAY. THEY GIVE YOU RECIPES WHICH YOU HAVE TO FOLLOW, AND YOU DO NOT HAVE TIME TO REFLECT ON WHY YOU ARE DOING SOMETHING. BEING SELF-TAUGHT MEANS THAT YOU ARE CONSTANTLY ASKING QUESTIONS. WHEN YOU ARE NOT IN THE KITCHEN, YOU START TO QUESTION WHY SOMETHING MUST BE DONE IN A PARTICULAR WAY. IN THE KITCHEN YOU TRY DIFFERENT THINGS, SOMETIMES YOU WIN, SOMETIMES YOU LOSE BUT YOU ARE NOT CONSTRAINED BY THE BOUNDARIES." [159]

FIGURE 11. Restaurant back view with garden, Stéphanie

Biteau, 2013

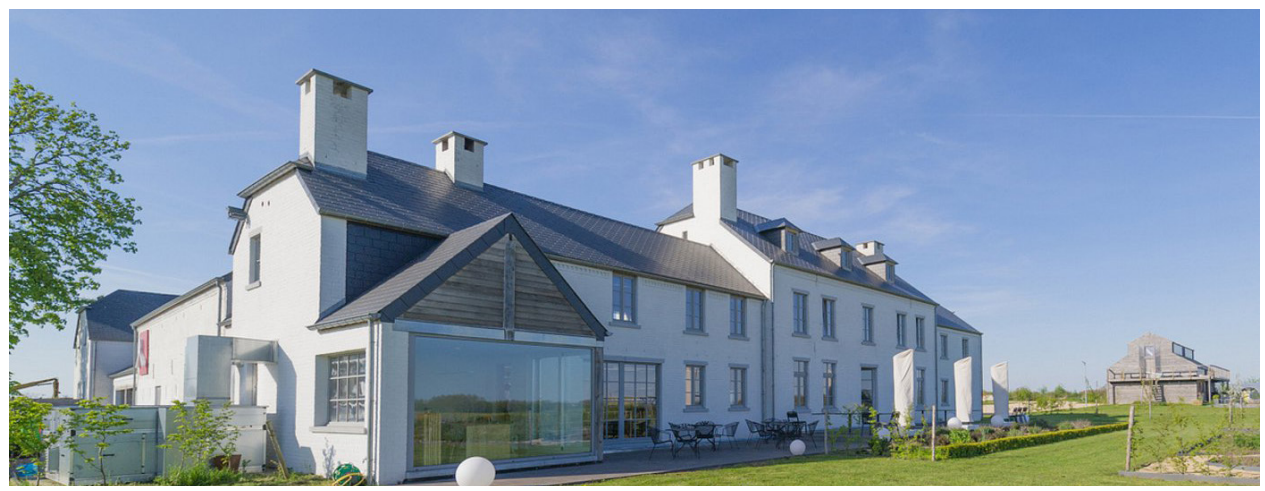

Since then it has been a constant evolution. From that days, he has moved to the top of the Belgian culinary world and is the fifth ranked among the best Belgian restaurants (Les Grandes Tables du Monde). He was selected as the foreign restaurant owner of the year by the Les Grandes Tables du Monde. In 2016, he was also nominated by restaurant guide Gault and Millau as the Belgian Chef of the year.

In 2000, Sang-Hoon Degeimbre opened his first restaurant, L'Air du Temps at Eghezée near Namur, in 2013 the restaurant moved location to Noville-sur-Mehaigne, a property set in five hectares of land. Soon, he decided to grow the vegetables, herbs and aromatic plants for the restaurant and hired a fulltime farmer. The dining room has a maximum capacity of 45 people. The restaurant serves lunches and dinners, and for lunch it offers an executive menu for $85 €$, "bowls", all the rest is à la carte. Two types of degustation menus are available, Signature Menu for $125 €$ and Plant Supremacy Menu for $185 €$. In 2000, L'Air du Temps won its first Michelin star, then a second in 2008 [160].

Hervé This was his mentor for molecular gastronomy, which allowed him to increase his knowledge about cooking processes over the years.

FIGURE 12. Some of Sang-Hoog's dishes, Stéphanie Biteau, 2014
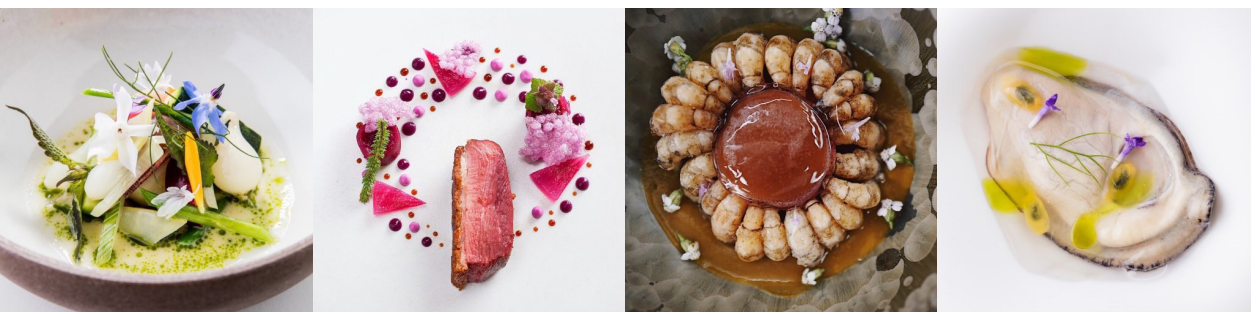
“WHEN I OPENED MY RESTAURANT IN 1997, I HAD NEVER COOKED BEFORE, EXCEPT FOR FRIENDS AT HOME. I COOKED FOR THE FIRST TIME ON THE OPENING NIGHT. BUT I NEEDED TO DEVELOP TECHNIQUES BECAUSE COOKING IS CHEMISTRY. I NEEDED TO UNDERSTAND THE CHEMISTRY BEHIND COOKING AND ALSO TO DEVELOP MY STYLE."[159]

From Korea he learned the techniques for preservation and fermentation which he uses to preserve excess of vegetables, reducing waste, and conferring a distinctive character to his food $\mathrm{He}$ also preserves oysters and scallops for months to create his own rich umami taste ingredient.

His previous experience as sommelier inspires him to create new drinks. Using an ultrasound machine to increase extraction efficiency, he creates flavoured waters to pair with the dishes at his restaurant. He also creates non-alcoholic 'wines' using this machine. To water he adds muscovado sugar, crushed red fruits, juniper seeds, cloves, pepper, and citric acid for acidity. For tannins he adds leaves from the garden. It is this inventive use of produce that makes Sang-Hoon Degeimbre restaurant so special.

\subsubsection{Team and Routine}

The internship had the duration of 3 month, of which 2 weeks were at the garden and 1 week at the innovation and development department. The working schedule was from 9 am to $3 \mathrm{pm}$, and from $6 \mathrm{pm}$ to 11 pm. Except when gardening that was from 8 am to $5 \mathrm{pm}$.

The team was composed by a total of 28 workers, 14 as cooks, 7 as waiters, 4 as gardeners, 3 from the office for marketing and chef assistance and 1 cleaning person. The 14 cooks, included Chef Sang Hoon Degeimbre, the Sub Chef Grégoire Gillard, the Development Chef George Priest, 6 cooks and 5 trainees. The dining staff is composed by the Maître Carine Nosal, Sommelier Maxime, 4 waiters and 1 trainee. The responsible for the vegetal and herbal production is gardener Benoit Blairvacq, among gardening personal there are also trainees.

The two sections in the main kitchen, where most time was spent during the internship were the Pastry and Bakery, and Starters and Amuse Bouche sections. The work developed involved tasks as preparing mise-en-place and dishes, and plating. At I\&D department the work developed involved preparing miseen-place, and collaboration in the development process through new suggestions and testing. At L'Air du Temp, all the kitchen staff is welcome to present new ideas for dishes. If they have potential, they are further developed at the I\&D department, being the last step the approval by Chef Sang Hoon Degeimbre. The service runs with a high level of organization, and everything is timed, organized and tidy, there is no rush in working, concentration of the staff and communication are focused in producing a perfect service.

Everyday fresh vegetables, flowers and herbs come from the garden, according to availability and the kitchen's order. The food that is not harvested at the Garden comes from local producers. The menu is always organized accordingly to the availability of seasonal products.

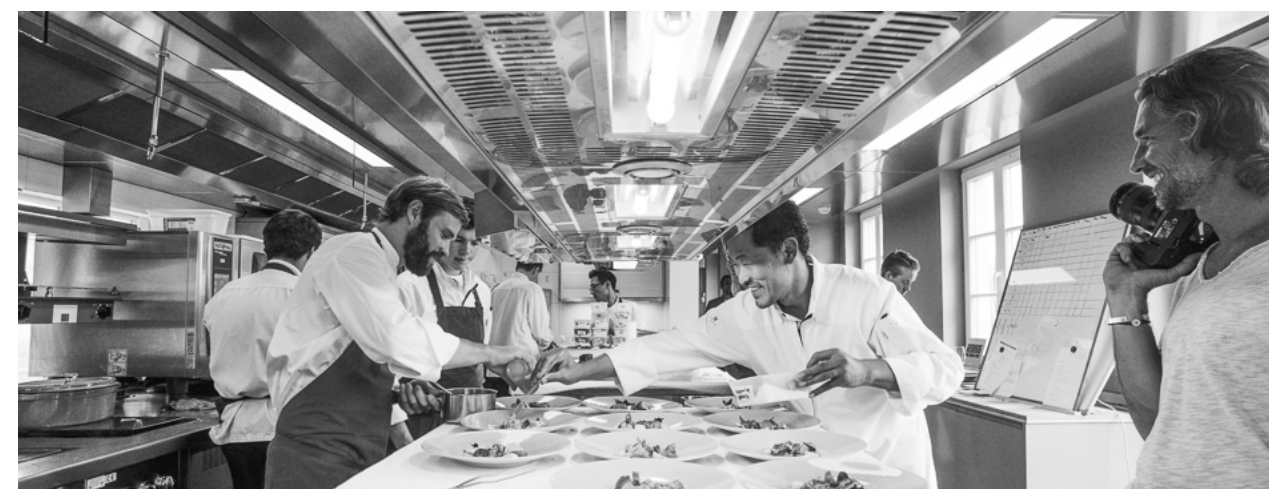

FIGURE 13. Chefs on the Pass, Stéphanie Biteau, 2014 


\subsubsection{Acquired skills and conclusions}

The internship at L'Air du Temps and working, aside Sang-Hoon Degeimbre, allowed the author to achieve a considerable growth in professional and personal terms. Sang-Hoon Degeimbre believes everyone is born creative and cooking is a learning process. His ten beliefs are:

- Creativity comes from constant questioning - and he always tells his team that everyone has a potential for creativity and that it is important to keep an open mind and to be aware of what is around us and to use it in a creative way;

- When there is a will there is a way - focus on one thing and push it as far as possible to make it happens;

IGURE 14. Staff,

Stéphanie Biteau,

2016

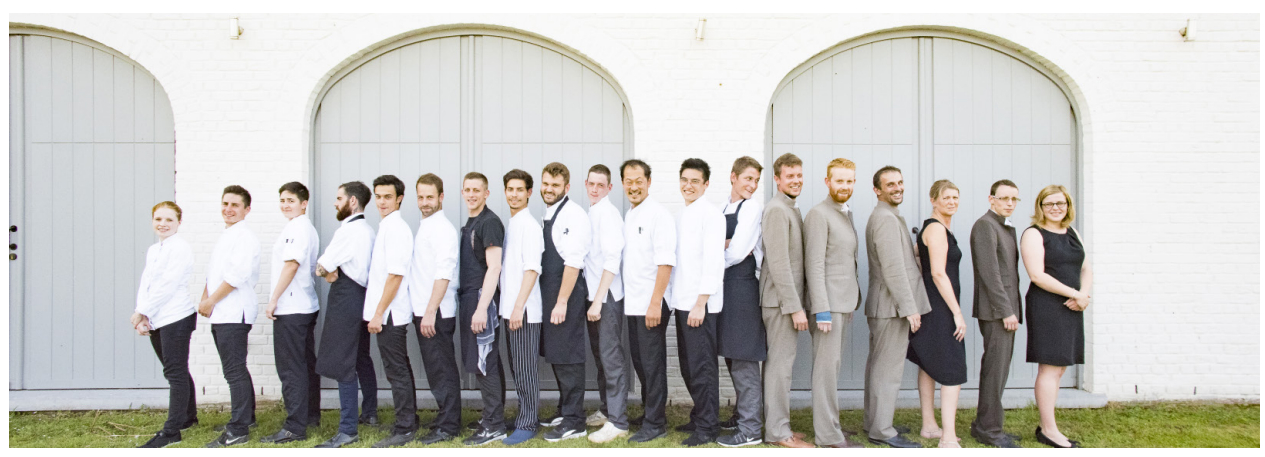

- It is never too late to change - In Sang-Hoon's kitchen there are many professionals who previously had careers in other areas, the gardener is a former banker. However, it is important to always be humble to learn.

- Follow your passion - knowing what you want and going for it;

- Constantly experiment and evolve. in life sometimes, one wins and others one loses. It is important to take detours, particularly as the results can be totally different from what expected. Continuing to innovate and be creative is the only way to evolve and discover new things;

- Less is more - many times there is a tendency to complicate things by adding various elements, great things sometimes come from less, not more.;

- Observe, listen, absorb, understand - these are Sang-Hoon's mantras. These four elements are always essential for anyone working in the creative fields;

- Teamwork is important - good results require the involvement of all the team, all the staff needs to be able to tell the story of a particular dish;

- Love what you do - cooking is about art, biology and gastronomy and it is the richest job in the world;

- If you cannot find what you want, create it yourself - having and creating his own garden also helped him to connect to nature, to use fermentation techniques out of necessity to ensure there is no waste.

The garden, the fields and the farmhouse are an important part of the restaurant's philosophy and hundreds of different varieties are bred by Benoit Blairvacq, the chief gardener, who is a passionate expert in gardening. The internship allowed the author to follow his work for two weeks, learning and absorbing every experience and knowledge about running a garden of 6 hectares - sowing, harvesting, cultivating, watering, planting and transplanting, among other tasks. For any cook the knowledge of these processes is crucial, particularly getting to taste each product on every stage of the crops. A biological, chemical and pesticides free, management is implemented on production, however the use of modern technology is also considered to find the best possible technique for achieving maximum flavours. 
The same approach is used in the kitchens and it was in this internship that the author had the first opportunity to work with the ultrasound technique, which encourage him to apply it at one of the dishes developed for this dissertation, the Sound of the Forest, corresponding to the hearing sense. Furthermore, the RotaVap is another equipment used, which allowed to understand the various advantages of its use, as a result this technique was also applied in the dish just mentioned.

Sous vide is another culinary technique that is quite used at L'Air du Temps, for cooking and impregnating, both approaches were also applied on the work developed for this dissertation. This method is important for sustainability, as it allows to increase products storage life and also allows to get excellent results with cheap cuts of meat. This technique was used for the hearing dish, Sound of the Forest.

Paco Jet, Water-Baths, Thermal Probes, Refractometer, pH Meters, Pressure Cookers, Precision Scales, Centrifuges are some of the equipment used at L'Air du Temps, all of them were already know from previous internships, but it was important to improve the ability to work with them.

Liquid Nitrogen is profusely applied with a variety of objectives, like tempering chocolate, separate segments of raspberries, visual effect on the table and so many other.

Another important aspect of the internship was increasing in the author the consciousness of the importance of organization and accuracy.

This professional experience contributed to understand how scientific knowledge can be applied in the professional restaurant business and its impact on costumer overall experience. It also contributed to improve the work developed for this dissertation. The contacts with people in the area, and the friendship bonds developed were also important, as well as the opportunity to improve the French language.

\subsection{EL CELLER DE CAN ROCA}

\subsubsection{Introduction and Objectives}

An internship at El Celler de Can Roca was an old wish and after 5 years of trials it was possible to achieve this objective, and to include this internship in the work experience acquired in the scope of this dissertation.

This professional experience was considered in one of the meetings with the supervisors of this dissertation, and it was assumed that it would be very valuable to learn/improve new skills, while combining all knowledge acquired during the master degree with the on job training, as El Celler de Can Roca is a restaurant well known for its scientific and multisensory approach to cooking, having a research and development department - La Masía (I+R). In fact, the knowledge about preparation and food production, equipment, techniques, methods of work, technology and so many other contents that define the quality and prestige of a fine dining restaurant, as El Celler de Can Roca, are extremely relevant to design a menu composed by five dishes with the characteristics of the one described ín this dissertation.

This three Michelin stared restaurant specialized in sustainability, local production and nature, is situated in the countryside, having some agricultural production. Its reputation in the gastronomy market has been related to technology, music, physics, design, bio-chemistry and neurology. All being studied with the collaboration of experts in each one of the areas, to achieve a good transference of knowledge and improve results and dinner's experiences. Undeniably, adapted as a receiving institution for a student designing a menu focused on psychophysiology.

Research, tasting, sensory analysis and discussion of results were incorporated in the working methods and philosophy at the El Celler de Can Roca. This provided a better understanding of the subject and helped to design the olfactory perception dish (chapter 7.2.) to provide a better sensory experience to the costumer. 
The main objective was to learn on the job, contact with the company's policy and methodology and improve knowledge acquired at the Master in Gastronomical Sciences. It was also intended to design and define methods, as well as the sensory tastings of the olfactory dish presented in this dissertation. Important inputs for designing the remaining menu were also received.

\subsubsection{Restaurant \& Chefs}

El Celler de Can Roca is a restaurant in Girona, Catalonia, Spain, opened in 1986 and owned by the Roca three brothers, Joan, in the kitchen, Josep as sommelier and in the dining room and Jordi as pastry chef. It was first located next to their parents' restaurant Can Roca but moved to its current purpose-built building in 2007.

El Celler is a free-style restaurant, committed to the avant-garde cuisine, but based on the gastronomical memory of different generations of the family's ancestors.

The restaurant is composed of a $200 \mathrm{~m}^{2}$ kitchen, $200 \mathrm{~m}^{2}$ winery, $200 \mathrm{~m}^{2}$ dining room and $60 \mathrm{~m}^{2}$ hall, plus a welcoming garden. The Cellar has over 60 thousand bottles. The restaurant is a luminous, warm, harmonious and welcoming place where diners feel comfortable. The restaurant has a 60-member team, that takes its mission very seriously, with refined vision, talent and values. The team's secret lies in order, everyone knows what they are expected to do. It seats 55 customers, with a menu around $190 €$. The restaurant has an 11-month waiting list [161].

Figure 15. El Celler de Can Roca Kitchen, 2017

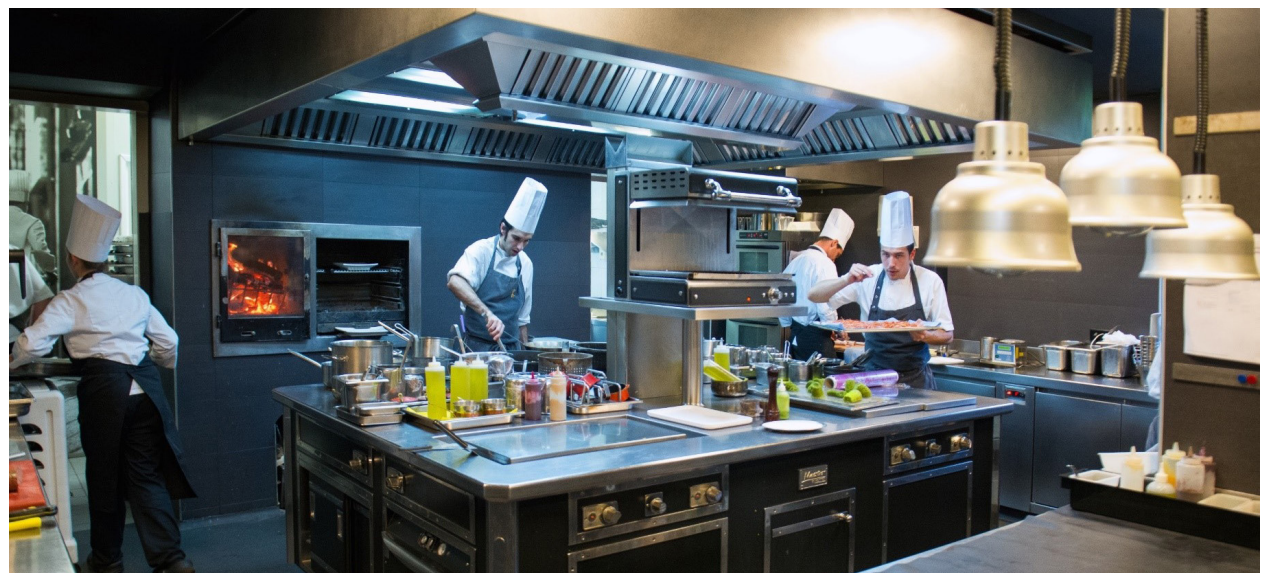

All the Roca brothers studied at the Girona Catering School and believe in pedagogy as the basis for the professionals of the future. They are all winners of the National Gastronomy Award and are all honorary doctors of the University of Girona. All the leading restaurant guides and gastronomy critics have acknowledged EI Celler's achievements over its first twenty-five years. The first Michelin star was awarded in 1995; the second in 2002. And the third on November 25, 2009. In 2009, El Celler de Can Roca got to the 5th position at "The World's 50 Best Restaurants" list by the Restaurant Magazine.. It reached 4th place in 2010 and finally 2nd in 2011 and 2012. In 2013 and in 2015, the 1st position was achieved [161]. At the moment, 2018, El Celler de Can Roca is the 2 nd Best Restaurant of the World.

Roca's cooking has a distinct identity and is inspired by their background and Catalan cuisine. The aromas picked up by Josep's nose are transformed into sweet or savoury recipes by Joan and Jordi. Slowly but surely, they have honed a recognisable style of cooking, born of their own and different lines of research: sous-vide cooking, cooking with wine, adaptation of fragrances, smoking, chromotherapy, etc [161]. The result is a technological cuisine with soul and memory, always elegant, refined, subtle and with a strong intellectual component and where technical and aesthetic perfection are achieved. 
The restaurant primarily uses local ingredients from the Catalan area. Simple flavour combinations are integrated with culinary techniques and unusual presentations of food.
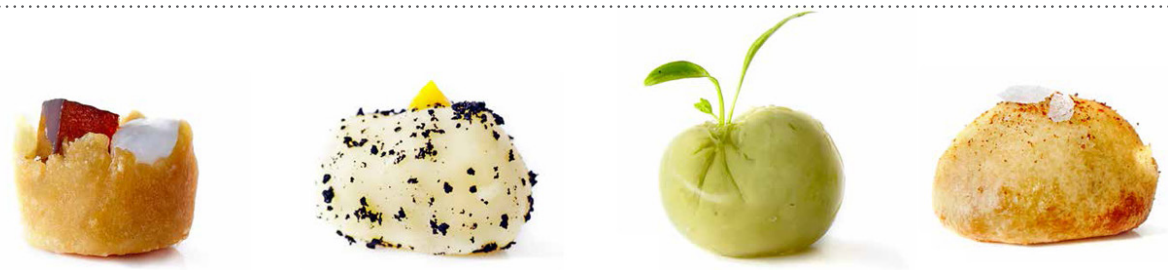

Figure 16. El Celler

de Can Roca The

World Dish, Juan

Pujol-Creus, 2016

When diners first arrive, they are given a selection of small bites from a section of the kitchen called "EI Món" (means The World in Catalan), that only produces small snack portions. They typically demonstrate flavours from around the world and come in sets of five in a purpose-built wooden holder. These introduce the diners to the unusual techniques and presentations of the restaurants. For example, a small ball of frozen spiced fish stock coated in cocoa butter represents Thailand. While there are typical fine dining ingredients included in the menu, such as lobster and foie gras, due to the Catalan influence, ingredients such as pigeon, hake and pig's trotters also appear. Moreover, they have created some dishes and desserts based on perfumes such as Calvin Klein's Eternity, Carolina Herrera, Lancôme and Bulgari. This has resulted in a perfume being released by the restaurant itself, called Nuvol de llimona. It was based on a dessert served at the restaurant called - The Perfume, being initially developed to spray as a mist over the diners while they ate the dish.

The main objective is enhancing or magnifying the flavour of great ingredients through precise cooking, and complementary or contrasting elements to highlight the uniqueness of the dish. Furthermore, the duration of the meal has become unusually long, often more than three hours, with multiple courses, often more than 20 steps, many of which consist of multiple parts.

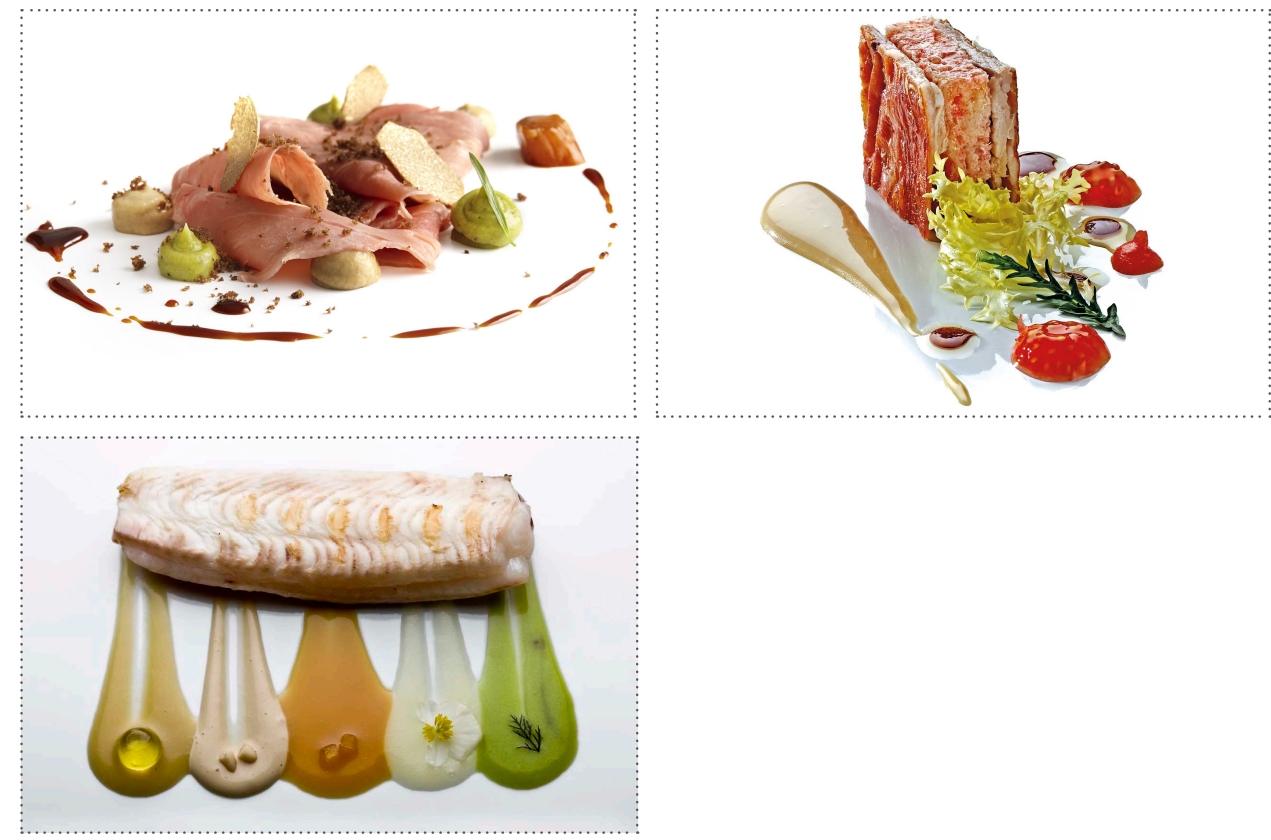

FIGURE 17. Some of El Celler de Can Roca Savoury dishes, David Ruano and Paco Amate, 2014 


\subsubsection{Routine and Team}

The internship, from 18th of April to 30 of June of 2017, took place at La Masía (I+R) from El Celler de Can Roca, located in one building, next to the restaurant, housing several departments under the supervision of Heloise Vilaseca, La Masía (I+R) manager. The average working schedule was from 9am to $7 \mathrm{pm}$. Work was mainly focused on the work/ study for this dissertation, particularly the smell sense dish. There was also the opportunity of participating in other projects at the distillery and the fermentation department Ars Natura Liquida, at RocaRecicla, RoCook, perfumery, participating in creativity meetings and so many other confidential projects related to the restaurant business. To the possible extent some of them will be explained on the following pages.

FIGURE 18. Some of

El Celler de Can Roca

pastry dishes, Juan

Pujol-Creus, 2016

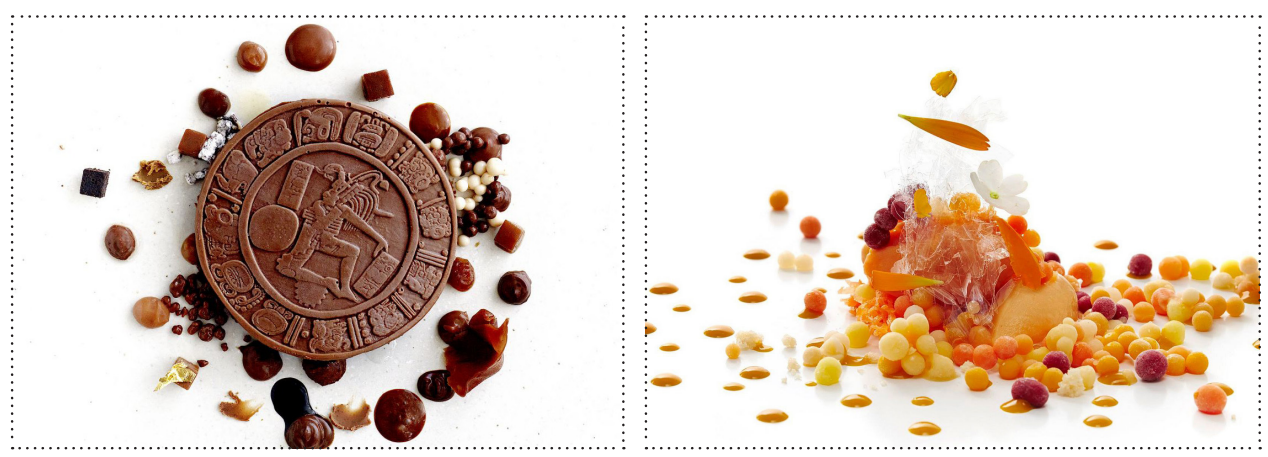

La Masia (LM) is a creative center responsible for all the projects, research and training at El Celler de Can Roca. Every Tuesday afternoon the kitchen studio of LM offers master classes on subjects such as hydrocolloids and texturizers, food technology and machinery, creativity, exhibition of techniques used in the tasting menu of El Celler de Can Roca, techniques of fermentation, etc. They are intended for the trainees and to the staff interested.

FIGURE 19. Formation with Chef Joan Roca at La Masía, El Celler de Can Roca, 2017

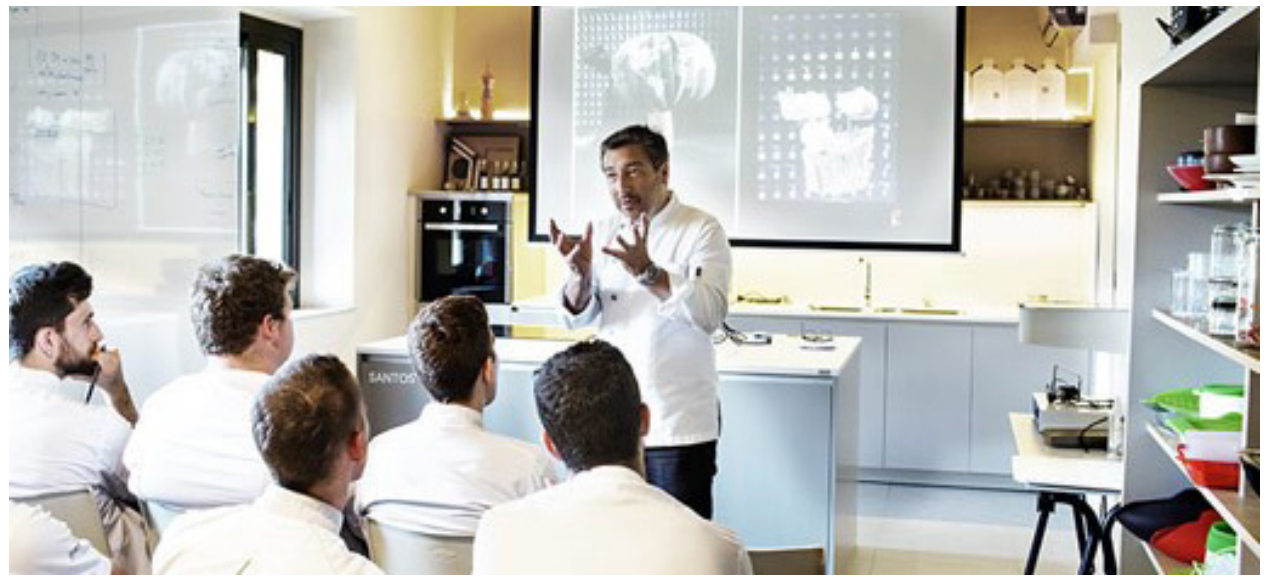

RocaRecicla is an independent workshop with a focus on reusing or recovering broken or damaged vitreous plateware and glassware, converting the disposable into original pieces used at the restaurant.

There are internal projects related to alcoholic distillation and fermentation carried out at LM infrastructures (these two groups have come together to work as ARS Natura Liquida). LM also integrates a garden with horticultural crops that is called Living Land, it is associated with research projects on new cultures and culinary applications of these plants. In addition, the perfumery is a partnership with perfumers, to develop olfactory related products and its applications. Another long-standing project is related with cooking at low temperature, it is responsible for projects from the development of a RoCook induction hob with probe and precise temperature control, to the launch of Sous Vide books. 

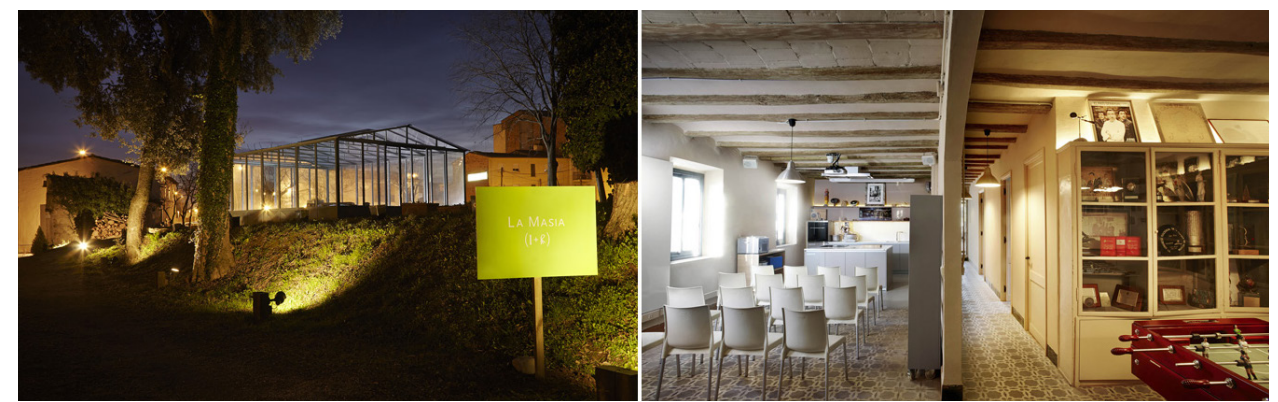

Figure 20. La Masía

from El Celler de

Can Roca inside and

outside, David Ruano

and Paco Amate,

2017

Inside the restaurant building, there is a Development Lab Kitchen responsible mainly for the creation of new dishes. Conceiving and designing a dish is a process that can take weeks. Beginning with an idea which gradually takes shape. There are some starting points, which range from tradition to memory, landscapes, the product, contrasts, the world of wine, perfumes, aromas, journeys, techniques and sometimes ideas that just run through. Ideas can originate from many different areas, for example, singers of opera, industrial engineers, agricultural engineers, designers, painters According to Joan Roca: "Everything can inspire you, everything can work, everything may be useful to you. The greatest thing about cooking is that it is alive. Cooking helps you to understand life. Everything can be understood from a creative standpoint, and cooking is no exception." [161].

\subsubsection{Acquired skills and conclusions}

One of the departments that supports El Celler de Can Roca creativity and innovation is ARS Natura Liquida which, as already referred, has projects related to alcoholic fermentation and distillation, and also focuses on other fermentations and yeast tests. In the scope of their projects they produce wines and spirits from fruit and spices, vermouths, saké, etc. Production of tempeh, lacto fermentations and brining are also carried out. In average the aim is 3 or 4 new targets per week, in order to obtain new products, recipes or elements of them, that are sub-sequentially submitted for approval, if successfully validated they can be included in the menus. During the internship there was the opportunity to work in this department, particularly in the production of saké and spirits, from sub products from the kitchen (peelings, seeds or lumps removal), followed by the control, manipulation and annotation of their chemical characteristics, for instance: analysing the total soluble solids content (brix degrees), measuring the amount of acidity through titration, measurement of the $\mathrm{pH}$ with a pH meter. After approximately 20 days of fermentation, the distillation is performed using a copper distillation apparatus.

RocaRecicla collaborates in the development of the containers used for the sensory study on the scope of the smell dish of the menu (chapter 7.2.4.). With this purpose a few days were spent in this department to desig the pieces and producing them. This department has machinery like: sander, laminator, furnace, aerator and other smaller gadgets.

La Masía is literally a culinary school, apart from the Tuesday masterclasses, there is a competition each 4 month, in which trainees cook dishes from their regions. It's a process of professional and personal enrichment for all participants. In the Kitchen of the Restaurant some of the meticulous cooking techniques as dipping frozen balls of fish stock into cocoa butter using a needle, brining the meats, making bread doughs, pickling vegetables, freezing calamari in liquid nitrogen, blitzing them in a high power blender, then frozen this in piping bags, which would later be pushed out into a mould and blow torched to create a tubular shaped cracker. In a three Michelin start restaurant this amount of preparation, time, and effort is required.

In addition, the opportunity to work with several high value products provides a great experience that further refines skills. La Masía has equipment as copper distillation apparatus, pH meter, alcohol meter, fermentation greenhouse, RoCook induction plate, vacuum machine, Thermomix, RotaVap, Paco Jet, water-baths, thermal probes, refractometer, pressure cookers, analytic scales and horizontal centrifuge and there was opportunity to work with them. 
Every week at La Masía there is a daily meeting with the Chefs and Managers from different departments, where everyone explains what they expect to accomplish by the end of the day or week. the Roca brothers often participate to discuss what has been made and to give supervision.

During the internship period, there was also the opportunity to participate at the University of Tourism in Girona, on May 17, 2017, in a conference with chefs Joan Roca and Gastón Acurio Jaramillo (from Peru) about the food industry as a form of integration and social sharing. On April 25, 2017, at Museum of the Drawing of Barcelona there was a talk between Javier Bonet and Martí Guixé (both food designers), an event associated with a temporary exhibition titled "Tapas - design for food". According to Guixé the design ceased to be "luxury" in 1997 and became "care" in 2000, then in 2017 became "survival". The participation in this lecture was very important and useful as the theme was related with the one of this dissertation. On the 26th of June at the congress center of Girona, Ferran Adriá gave a talk (see figure 21) about the true meaning of gastronomy, cuisine and creative process, entitled "Sapiens, Understand to Create".

Figure 21. Ferran

Adriá Presentation

"Sapiens, Understand

to Create", Rui Mota,

2017

FIGURE 22. Presentation about Food Design, Rui Mota, 2017
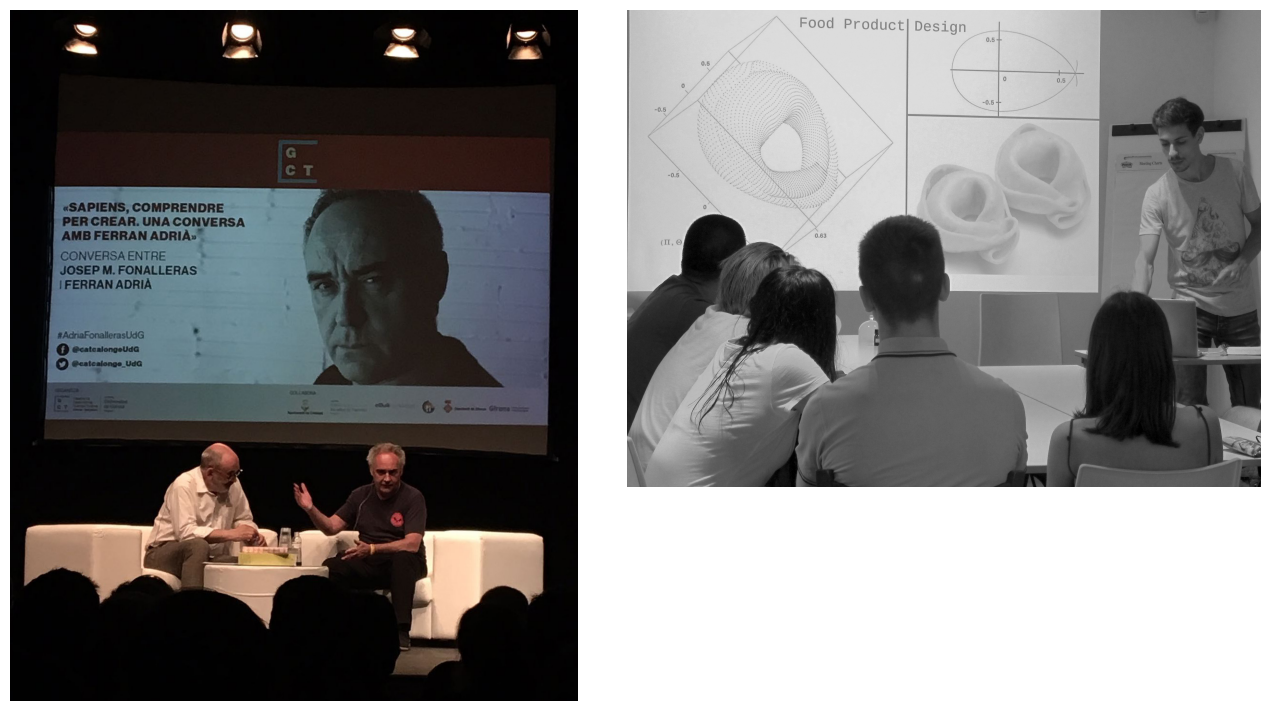

In the last day of the internship a talk (see figure 22) was given for the whole staff about the concept of Food Design and the presentation of the results of the work developed during the internship.

The work developed during the internship, and particularly design and production of the containers, tests, the food sample used for the research and the sensory analysis done at La Masía, contributed to an increased awareness about the importance of a detailed planning and organization of every task, in order to reduce errors, save time and improve results. This professional experience contributed to the achievement of a better thesis content and to the understanding of how academic knowledge can be applied in a $R \& D$ centre at a restaurant and how it may create an impact on consumers overall experience.

This opportunity also contributed to increase professional and personal networks, to develop bonds of friendship and the opportunity to improve the Spanish language and Catalan. 


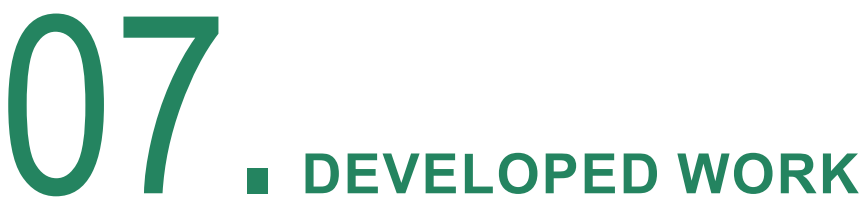

The work developed for this dissertation required the understanding the rules of visual composition and design and know-how about kitchen techniques which were integrated with knowledge from the food science, gastrophysics and neuroscience areas. It was planned and develop a full degustation menu composed by 5 dishes, each one mainly associated to a different human sense.

The menu is inspired by the woods and the dishes represent different stages during the day. The 5 dishes are contextualized and respect design guidelines that adapt and illustrate forest physiognomies.

The first moment, Mooning Walk, starts in the night darkness represented in the amuse bouche by using darker colours like dark blue, brown, black, grey, neon lights. This dish is related to sight sense, has strong visual composition dimensions, optical illusion, 3D and fluorescence effects, inspired by fireflies, owls, branches, moon, stars, etc. One of the main objectives was to introduce illusion, bluff, mystery, darkness, surprises and all of the phantasm that the forest has in the night; applied design techniques as movement and gravity fulfill this dish character. Besides, it has double reading according to its illumination, corresponding to the moonlight and the sunrising.

The second dish, the starter, is focused on the smell sense, and is called the Drinkable Smoke. The scenario is also committed to fit the forest theme, inspired in the sunny mornings with animals and flower. Composed by bright colours and different earthy aromas. Ginger and green mandarin essential oils were used to enhance olfactory cues, as well as aromatic herbs, flowers and spices for infusions and smoking. Pine charcoal was applied on cooking and smoking process. This dish development was part of a sensory analyses study where statistics, neuroscience, gastrophysics and design contributed to significantly identify and select the container to be used. The study was presented at the $1^{\text {st }}$ International Conference on Food Design and Food Studies: Experiencing Food and Designing Dialogues, and resulted in a paper [2]. Subsequently two containers were designed at Vista Alegre Atlantis and one of them was already launched in the Chef Collection on the international market signed by the author and associated with El Celler de Can Roca.

The third moment, Sound of the Forest, is the main course focused on the hearing sense. The dish is supposed to look like the authentic flora, represented by herbs and flowers, $100 \%$ dark chocolate is used to make the branches and wooden sticks, it includes also a river, forest dew, baby vegetables and truffles, all this garnish a sous vide cooked rabbit loin. As the relevant sense here is audition, the dish is paired with an audio component: an iPod hidden inside a tree branch is placed aside the dish reproducing some forest sounds: water stream, birds chirping, wind, breeze and branches breaking. This melody intends to focus the consumer attention in the dish details and increase appreciation.

The forth moment, Greenly Fresh, is directed to the taste sense and is a small pre-dessert to clean the palate, working as an introduction for the next sweet dish. Senses, specially the taste easily get saturated, so it is important to make a break that awakens it again. Keeping the theme in the woods, this dish represents the green herbs with acid tastes.

The fifth and last moment of the study case is a dessert, Beet Grains, associated to the touch sense. It is inspired in the beetroot and represents the sunset of the forest' sky with purple and red natural colours from 
the beet. It is composed by 15 elements and each of them produces completely different touch sensations. Between temperature, moisture, creaminess, crunchiness, chewiness and fluidity, this dish is a complete journey around the textures in one forest. A Focus Group was run with Ritzs Four Season's Chefs in order to get an objetive evaluation.

After an extensive work comprising steps of testing, designing, cooking and developing these dishes the result is presented below as well as all the research done in parallel with the practical component.

\subsection{SIGHT}

\subsubsection{Objetives}

Visual receptors are the first to be stimulated prior to the consumption of food. Apart from increasing the production of saliva and gastric juices, vision insights trigger emotions, interest and expectations related to the taste, flavour, and enjoyment of a given dish. In fact, the vision of a dish in a restaurant, allows to estimate (consciously or not) its likely value [121].

This is the sense associated with the first moment of the menu, the amuse bouche. Night darkness is represented using darker colours than usual: dark blue, brown, black, grey, and fluorescence. In fact, there are not that many ingredients that in their natural state are dark, blue or yellow. Thus this dish was designed to produce new expectations and an innovative sensory perception.

Being related to the sight sense, visual composition is crucial. Fundamental principles of visual composition associated to food, according to Spence (2015) are colour, shape, exterior texture, brightness, clarity and transparency. Apart from these elements, others were introduced to increase either the expected or actual satisfaction of the diners as: optical illusion, 3D and fluorescence effects. One of the main objectives was to create illusion, bluff, mystery, darkness, surprises and introduce some elements common in a forest at night.

For most chefs, the plating of food is approached in an intuitive manner. However, the understanding of how differences in the visual arrangement of the food on a plate may modify the diner's expectations, and their subsequent experience of the food, is still far from known, but a great amount of research has been undertaken about this [79].

Acquiring additional evidence related to the impact of vision on the experience of food is clearly of growing relevance, also an increasing number of chefs, artists, and designers are currently interested in utilizing different materials and/or textures in their food, plateware, cutlery, and even the texture of the restaurant seat itself [55]. Recently, movement and technology are becoming a trend at fine dining restaurants, to enhance the taste/flavour of food, to provide entertainment and/or to deliver memorable experiences around food and drink and to provide healthier eating [88].

For example, through the use of interactive containers that react on contact with the food, emitting sounds and vibrations and generating luminescence and moving images. Another examples of this approachare the edible luminescence work of Pastry Chef Janice Wong [163]. The El Somni project by El Celler de Can Roca [57], Sublimotion by Paco Roncero and The Fat Duck by Heston Blumenthal [147].

Studying food presentations under the lens of psychology and sensory science could give precious insights to the so far empirical, art of plating [52]. "Aesthetic response can be studied rigorously and meaningfully within the framework of scientific psychology" [164]. 


\subsubsection{Dish Composition}

A set of 8 elements compose the visible message of this dish, called Mooning Walk. It is characterised by the overnight changeover, represented by the fireflies, owls, branches, moon, and others, which allow to play with illusion, darkness, surprises and represent all the "phantoms" that a forest has at night. As light changes, while the dish is served, a different visual composition will come up which allows $\mathrm{s}$ different reading.

Deep fried wild pigeon hair, food that moves itself, among others visual cues (see figure 23, se also recipe in 10.1.).

Being an amuse bouche it is served in bite-sized pieces. The main ingredients used are wild pigeon, katsuobushi, brandy tonic water and white grapefruit essential oil.

1 | Wild pigeon hair - The pigeon meat was chosen due to its distinctive flavours and leanness. Wild pigeons are also guided by the magnetic fields of the planet. For these reasons this bird was chosen as the main ingredient in this dish in whish magnetic effects are used. After being boiled, finely shredded and deep fried, the pigeon meat has a consistency and lightness, reminding a bundle of crispy straw.

2 | Tonic and white grapefruit fluid gel - Tonic water has quinine that glows under blacklights, and is transparent under normal light, allowing to provide different visual readings. It also gives a bitter taste to the dish. White grapefruit essential oil was chosen to pair the flavours of the pigeon, contributing to its citrus profile.

3 | Katsuobushi flakes - This are flakes of dried, fermented, and smoked skipjack tuna. One of the most traditional ingredients in Japanese cuisine. Katsuobushi's distinct umami taste comes from its high inosinic acid content. Traditionally made katsuobushi, known as karebushi, is deliberately incubated with Aspergillus glaucus fungus in order to reduce moisture [165]. Upon being placed on hot food, the heat waves cause the thin and light katsuobushi flakes to move about, giving it a special aesthetic look, contributing for an additional visual component.

4 | Riboflavin Sauce - Prepared using Glow by SOSA, with Riboflavin (E101), also known as vitamin B2, which was hydrated and thicken with Xanthan. Under normal light is yellow and under blacklight becomes fluorescent. Represents the fireflies and all the mysterious night animals.

5 | Tagete Petals - contribute to colour contrast and provide dry and acid vegetal flavour to the dish. Provided by Microgreens ${ }^{\circledR}$, under blacklight turn bordeaux.

6 | Pea Sprouts - freshly picked, washed and plated. Apart from the interesting spirals shapes, this sprout tastes as dry cereals.

7 | Fig's Jam - contributing for a sweet taste on the dish, matches well the pigeon flavour plus works as a base for stability. Another reason for applying this fruit, was to match the fig leaf used as plate.

8| Curcuma Powder - A spice with yellowish pigments, that also glows in the dark. This Indian spice, after being toasted, was sprinkled on the pigeon.

All the elements were placed on top of a fig's leaf (Figure 23 and 24) and were photographed in two moments, under blacklight (Figure 24) and normal light (Figure 23), revealing different identities and perspectives. The fig's leaf appears floating due to a magnetic levitation system hidden inside the dining table. The fluorescence colours were registered using a 18 wats blacklight and an analogic digital camera. In order to allow a direct contact with the levitation system no cutlery is provided with this dish, fingers are intended to be used when tasting for a further direct perception. 
FIGURE 23. Mooning walk, top view under sunlight.

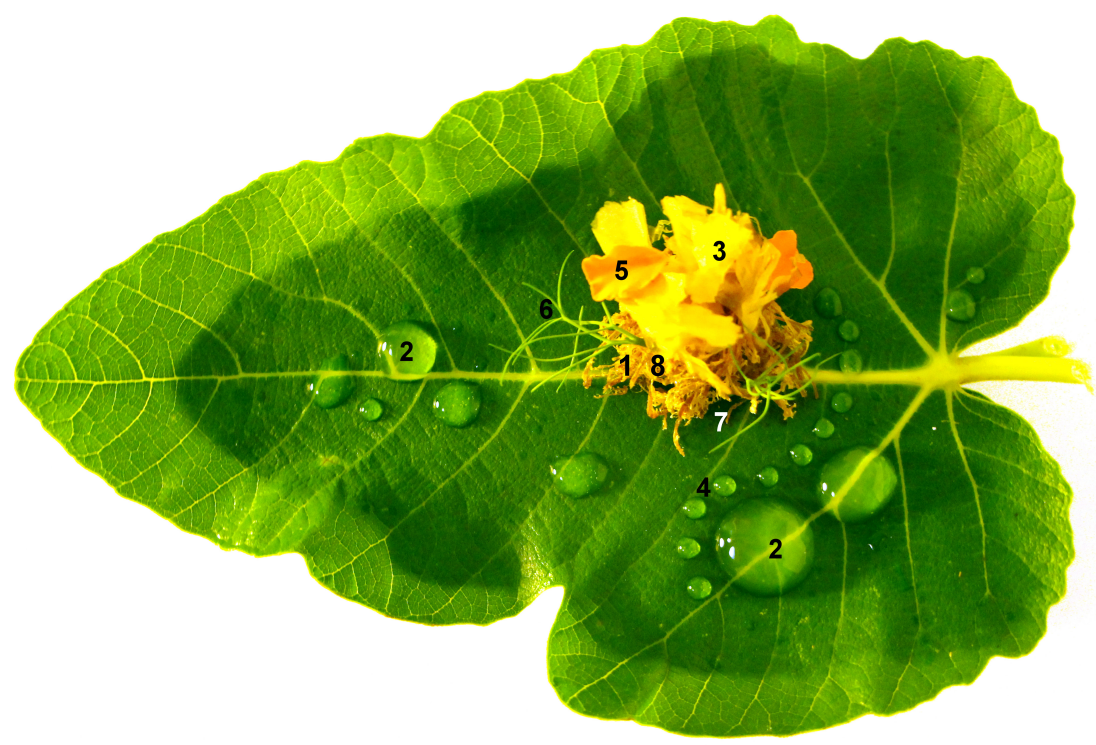

\subsubsection{Techniques applied}

Spectacular visual cues come from the fluorescence characteristics of the food elements and from the levitation system, providing movement and optical illusion on the visual readings. Several culinary techniques were used, being the most uncommon referred below.

2 - Tonic and white grapefruit fluid gel - To obtain a fluid gel gellan gums was used for jellification, then the gel was mixed with a hand blender. This causes a disruption of the three-dimensional structure of the gel and small particles are obtained. The fluid gel is then passed through a sieve to prevent the presence of unbroken pieces of gel or lumps of undissolved powder. Fluid gels with different viscosities can be obtained, depending on the initial strength of the gel. This technique allows a better release of flavours compared to the use of starch to thicken sauces, for example. The type of gellan used for this purpose is low-acyl gellan which results in more rigid and stiff gels (for a consistent fluid gel), however, this is more sensitive to the presence of minerals than high-acyl gellan which results in less firm and less consistent gels [157].

2, 4 and 8 - Tonic water, riboflavin sauce and curcuma powder are fluorescent. A worldwide known term, "neon colour" by Hermann von Helmholtz and "fluorescent" by Ralph M. Evans, has inspired the author to apply it on the Vision dish. The use of fluorescence, apart from the spectacular effect, also simulates bioluminescence organisms as fireflies which naturally produce light by chemical reactions [166]-[168].

Luminescence is the emission of light from any substance that has absorbed light or other electromagnetic radiation. Luminescence is formally divided into two categories: fluorescence and phosphorescence. Fluorescent materials cease to glow immediately when the radiation source stops, unlike with phosphorescence, where they continue to emit light for some time after [168]. The most striking example of fluorescence occurs when the absorbed radiation is in the ultraviolet region of the spectrum, and thus invisible to the human eye, while the emitted light is in the visible region, which gives the fluorescent substance a distinct colour that can be seen only when exposed to UV light.

Blacklights mostly emit higher-frequency ultraviolet light, which is outside the visible light spectrum. Inside the glass tube is a partial vacuum and a small amount of mercury. An electric discharge in the tube causes the mercury atoms to emit mostly ultraviolet light. The glass lamp is lined with a coating of a fluorescent material. [166], [169], [170].

Fluorescence typically occurs in aromatic molecules. One widely encountered fluorophore is quinine, which is present in tonic water [166], [169], [170]. 


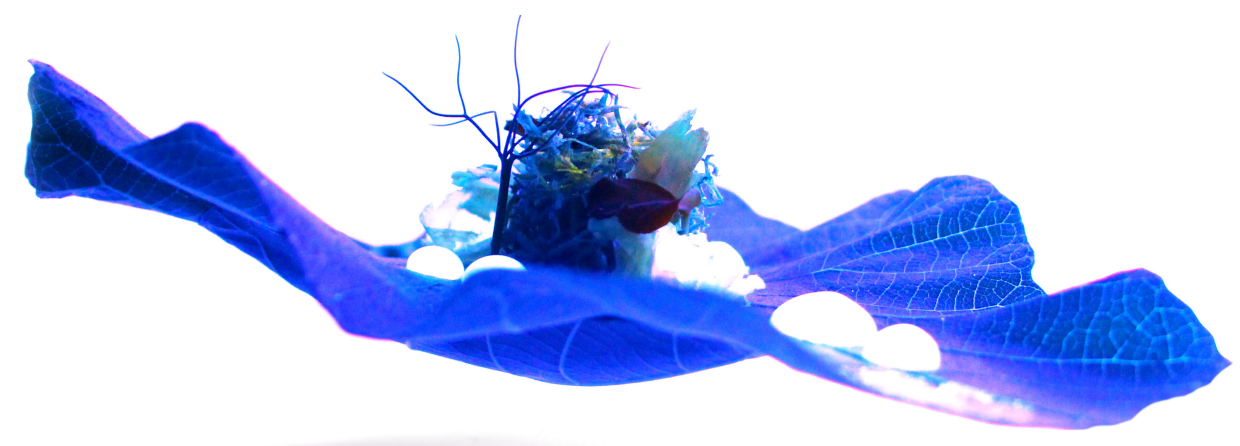

FIGURE 24. Mooning walk, under blacklight front view, 2018

Riboflavin (Glow by SOSA) a compound better known as vitamin B2 (see figure 25), and Curcumin, a bright yellow chemical produced by some plants as for example Curcuma longa, were the other fluorescent elements used.

Flavin adenine dinucleotide (FAD)

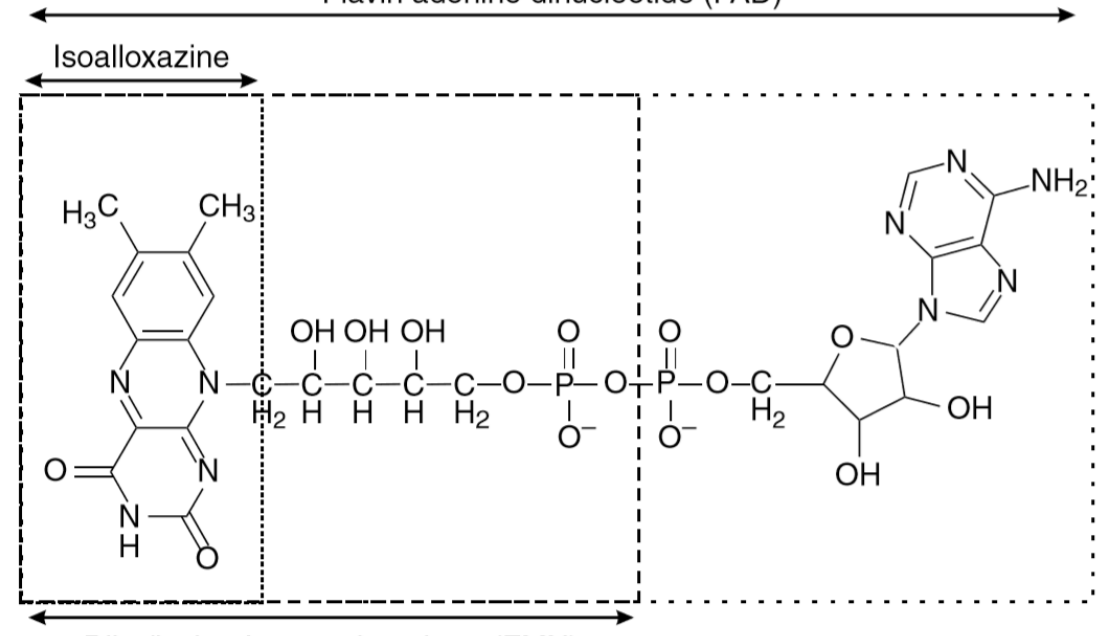

Riboflavin-5'-monophosphate (FMN)
Figure 25. Riboflavin structure, Johnson, 1955

Use of magnetic effects - Modernist cooking has relied, at least in part, on the development and utilization of new technologies in the kitchen [88]. The magnetic levitation system (see figure 26) is not something completely new, is used at Sublimotion and at The Fat Duck [88]. Here was used as a levitation system. It is composed of a circular magnet, also known as magnetic ring spinning, as plate holder and stand.

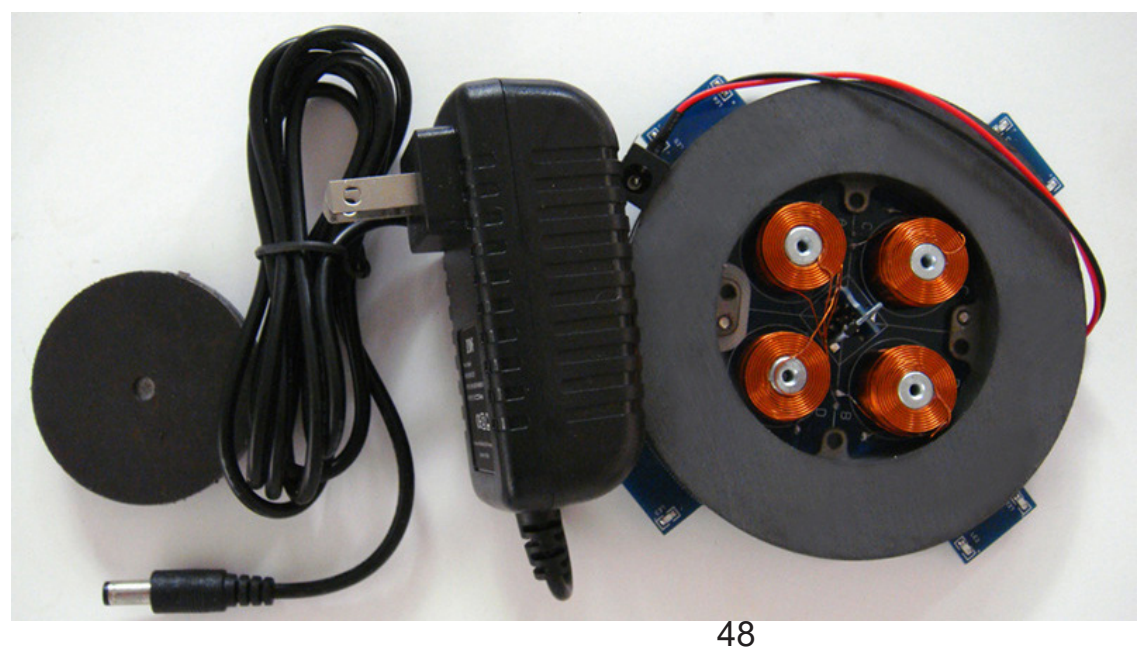

FIGURE 26. Magnetic levitation, maglev or magnetic suspension, Thompson, 2000 
Magnetic levitation, maglev or magnetic suspension is a method by which an object is suspended with no support other than magnetic fields. Magnetic force is used to counteract the effects of the gravitational acceleration and any other accelerations. There are two issues associated within: Lifting forces, providing an upward force enough to counteract gravity, and stability, ensuring that the system does not spontaneously slide or flip into a configuration where the lift is neutralized. Thus, two simple dipole magnets repelling each other are highly unstable, since the top magnet can slide sideways, or flip over. However, servomechanisms, the use of diamagnetic materials, super conduction, or systems involving eddy currents allow stability to be achieved [171]-[173].

\subsubsection{Plate Design}

This dish was developed in 4 phases, applying the Double Diamond design process [1]:

$1^{\text {st }}$ Phase - Discover how could sight cues be used in a dish, investigate similar works, as well as literature about results from previous studies on the influence of vision on the sensory perception. Brainstorming of what could be new to introduce in the "sight dish" of this menu.

$2^{\text {nd }}$ Phase - Define the brainstorming results and select what is really related to the sight sense, focus on the objectives and avoid distractions or references to other senses (see figure 27).

$3^{\text {rd }}$ Phase - Develop prototypes, test elements and recipes. Check the whole ergonomy of the system, confirm colours and light set, define plating, etc.

$4^{\text {th }}$ Phase - Delivery the final version of the dish.

FIGURE 27. Ergonomy

drafts, 2018

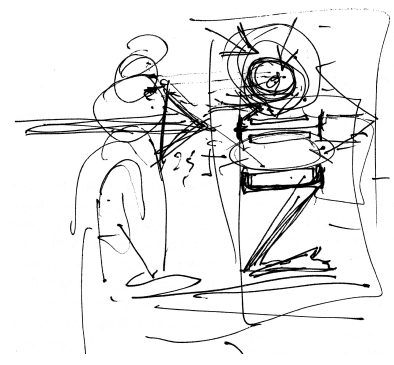

The various aspects of visual composition included, for instance, the colour of the food or elements of the dish, the visual texture of the components and their combination, the shape of the individual components, and the higher-order spatial arrangement of the various elements. Even the number of items on the plate (odd versus even) can potentially make a difference to a diner's impression of a dish [130].

One of the most fascinating features of this dish is having double readings, blacklight creates its own perspective of food elements as they appear different as they do under normal light, the elements to include were studied and tested in order to create two moments of visual perception during consumption of this dish. These represent the two phases of the day in the woods, precisely in day and night light, as well as the elements of fauna and flora that variate along. Changes of colours from dark blue, brown, black, grey, neon bright lights (yellow, white, light blue) to green, orange, yellow, brown and even transparent,caused by changing the light can arouse interest, reveal mystery and interrogation, eventually involving emotions and mark the memory of the taster as intended [63], [103].

A fig's leaf was used as plate, being the plating choice guided by general principles of visual harmony, which were selected to include movement, unity, variety, balance, rhythm, emphasis, contrast, proportion and pattern [130] defining a completely natural form with organic edges and colours. Movement, rhythm and optical illusion were included by the levitation system. The top base magnet was hidden inside the 
leaves and glued, while the bottom base magnets was previously craved inside the table, it rotates as a consequence of the placing impulse by the waiter.

Different platings (see figures 28, 29, 30 and 31) were produced transmitting each one a different input/ vision that also changes with the perspective in which it is observed (or photographed). On Table 1 the comparison between the 3 different platings, under black light and normal light is presented.
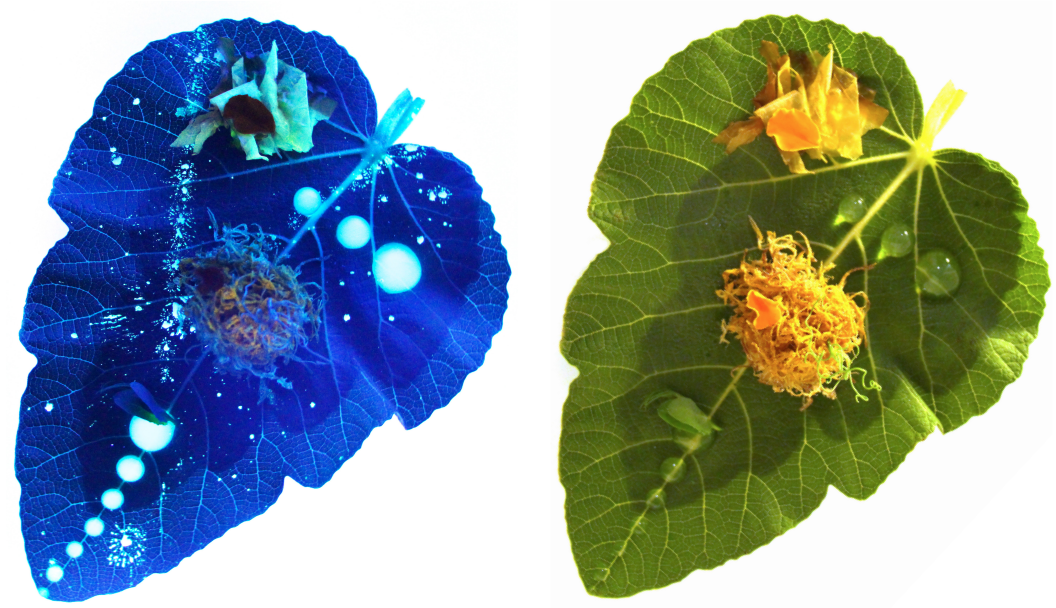

FIGURE 28. Mooning walk plating 1 , under blacklight (left) under sunlight (right), 2018

Under blacklight the dishes resemble a galaxy, with its orbits, stars and some planets at night sky. Reminding the night animals paths, journeys or footprints. When under the sun light some elements of the visual composition vanish intriguing the taster, arousing curiosity and clearing the senses. Brighter and clearer objects are perceived, and this can be considered as extra feature provided by the light changing. This dish can be eaten using a wooden spoon to avoid interference with the magnetic fields, fingers can also be used to lift the food towards the mouth.

Concerning the balance of this dishes, usually items occupying central locations tend to be preferred, being this known the "Power of the Center" [164]. As an amuse bouche all the food elements were plated mainly in the middle of the leaf. Otherwise, unbalanced plating could be perceived as being more creative than balanced plating [164].
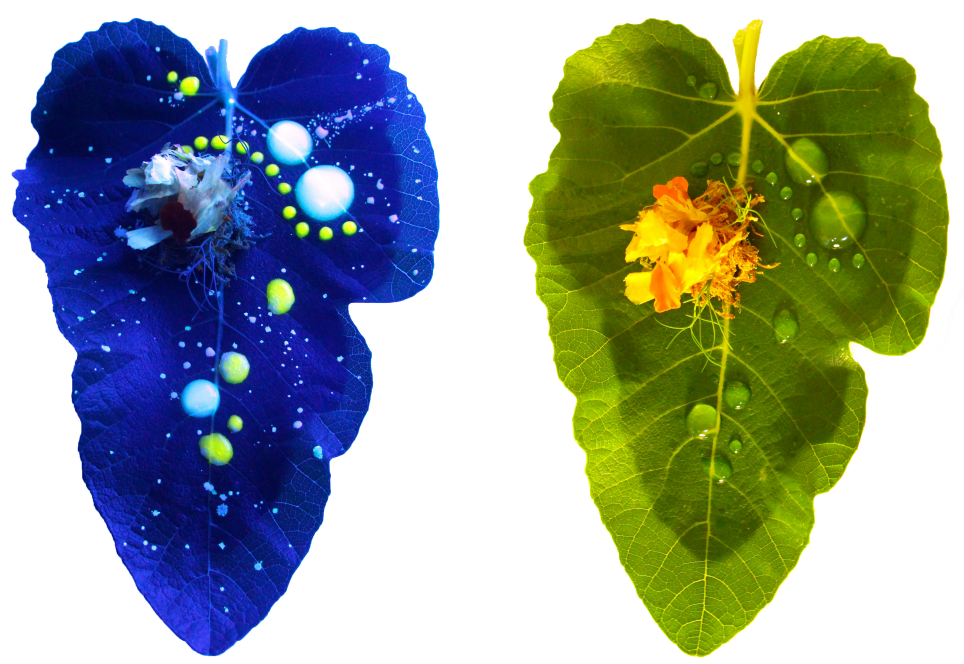

FIGURE 29. Mooning walk plating 3 , under blacklight (left) under sunlight (right), 2018 


\begin{tabular}{|c|c|c|c|c|c|c|}
\hline & $\begin{array}{l}\text { CHROMATIC CON- } \\
\text { TRAST }\end{array}$ & $\begin{array}{l}\text { DOT, LINE, BAL- } \\
\text { ANCE }\end{array}$ & $\begin{array}{l}\text { PLANE, VOLUME, } \\
\text { SHAPE }\end{array}$ & $\begin{array}{l}\text { MOVEMENT, DIREC- } \\
\text { TION, RHYTHM }\end{array}$ & TEXTURE, SPACE & OBS. \\
\hline $\begin{array}{l}1 \\
\mathrm{BK}\end{array}$ & $\begin{array}{l}\text { There is contrast } \\
\text { of tone and } \\
\text { brightness. } \\
\text { Contrast of } \\
\text { colour and tem- } \\
\text { perature does } \\
\text { not exist. }\end{array}$ & $\begin{array}{l}\text { Several dots } \\
\text { constituting } \\
\text { lines, the space } \\
\text { is mostly occu- } \\
\text { pied, balance by } \\
\text { dispersion and } \\
\text { compensation }\end{array}$ & $\begin{array}{l}\text { Various dots of } \\
\text { different sizes, } \\
\text { round shapes } \\
\text { dominate, } 3 \text { lines } \\
\text { can be read }\end{array}$ & $\begin{array}{l}\text { Perpendicular lines } \\
\text { create dynamics } \\
\text { in the continuous } \\
\text { reading } \\
\text { neutral space }\end{array}$ & $\begin{array}{l}\text { Filamentous } \\
\text { and marked } \\
\text { texture }\end{array}$ & $\begin{array}{l}\text { Resembles } \\
\text { a constel- } \\
\text { lation, sky, } \\
\text { universe, } \\
\text { cold, depth }\end{array}$ \\
\hline $1 \mathrm{~S}$ & $\begin{array}{l}\text { Strong contrast } \\
\text { of colour }\end{array}$ & $\begin{array}{l}\text { Two non-sym- } \\
\text { metrical dots } \\
\text { generate im- } \\
\text { balance, two } \\
\text { transparent } \\
\text { lines formed by } \\
\text { points }\end{array}$ & $\begin{array}{l}\text { Two large dots } \\
\text { with irregular } \\
\text { round shape, The } \\
\text { shadow reveal } \\
\text { substantial height }\end{array}$ & $\begin{array}{l}\text { Without move- } \\
\text { ment, static forms }\end{array}$ & $\begin{array}{l}\text { Suggested by } \\
\text { the filaments } \\
\text { and lines of } \\
\text { each shape }\end{array}$ & $\begin{array}{l}\text { Quite mo- } \\
\text { notonous } \\
\text { reading, min- } \\
\text { imization and } \\
\text { simplicity }\end{array}$ \\
\hline $\begin{array}{l}2 \\
\mathrm{BK}\end{array}$ & $\begin{array}{l}\text { Strong contrast } \\
\text { of colour and, } \\
\text { simultaneous } \\
\text { contrast of tone } \\
\text { and brightness }\end{array}$ & $\begin{array}{l}\text { Curved lines, } \\
\text { unbalanced - } \\
\text { right side with } \\
\text { greater compo- } \\
\text { sition, }\end{array}$ & $\begin{array}{l}\text { Very irregular } \\
\text { forms, despite } \\
\text { some dots, some } \\
\text { volume perceived }\end{array}$ & $\begin{array}{l}\text { Spontaneity, insta- } \\
\text { bility, randomness }\end{array}$ & $\begin{array}{l}\text { Crunchiness } \\
\text { suggested by } \\
\text { katsuobushi on } \\
\text { top and creamy } \\
\text { on sauces }\end{array}$ & $\begin{array}{l}\text { Constellation } \\
\text { of stars or } \\
\text { rails of night } \\
\text { animals }\end{array}$ \\
\hline $2 S$ & $\begin{array}{l}\text { Strong contrast, } \\
\text { at the level of } \\
\text { luminosity and } \\
\text { colour }\end{array}$ & $\begin{array}{l}\text { Transparent } \\
\text { dots. The food } \\
\text { has no visible } \\
\text { lines, only the } \\
\text { veins of the } \\
\text { leaf. Unbal- } \\
\text { anced for not } \\
\text { being centred }\end{array}$ & $\begin{array}{l}\text { Relative volume in } \\
\text { two planes }\end{array}$ & $\begin{array}{l}\text { Asymmetry domi- } \\
\text { nates in the com- } \\
\text { position }\end{array}$ & $\begin{array}{l}\text { Suggested by } \\
\text { the filaments } \\
\text { and lines }\end{array}$ & $\begin{array}{l}\text { Minimization } \\
\text { and simplic- } \\
\text { ity at visible } \\
\text { composition }\end{array}$ \\
\hline $\begin{array}{l}3 \\
\mathrm{BK}\end{array}$ & $\begin{array}{l}\text { Very sequential } \\
\text { tonal contrast, } \\
\text { simultaneous } \\
\text { contrast of black } \\
\text { blue, and blue } \\
\text { and white }\end{array}$ & $\begin{array}{l}\text { Symmetrical, } \\
\text { very balanced, } \\
\text { precise dots } \\
\text { and in harmony }\end{array}$ & $\begin{array}{l}\text { Round shapes, } \\
\text { uniform volume } \\
\text { with well-defined } \\
\text { secondary plane }\end{array}$ & $\begin{array}{l}\text { Size gradation, } \\
\text { constant rhythm, } \\
\text { defined fragmen- } \\
\text { tation }\end{array}$ & $\begin{array}{l}\text { Soft, creamy, } \\
\text { sweet }\end{array}$ & $\begin{array}{l}\text { Very bal- } \\
\text { anced, reg- } \\
\text { ular, subtle } \\
\text { and with } \\
\text { harmony }\end{array}$ \\
\hline $3 S$ & $\begin{array}{l}\text { Simultaneous } \\
\text { contrast of tones } \\
\text { from green to } \\
\text { brown and or- } \\
\text { ange to brown, }\end{array}$ & $\begin{array}{l}\text { Respected sym- } \\
\text { metric axis gen- } \\
\text { erates balance, } \\
\text { sequential and } \\
\text { compensatory } \\
\text { dots }\end{array}$ & $\begin{array}{l}\text { Diamond shaped } \\
\text { food }\end{array}$ & $\begin{array}{l}\text { Linear motion, } \\
\text { single direction }\end{array}$ & $\begin{array}{l}\text { Visible rough- } \\
\text { ness by pigeon } \\
\text { filaments, soft- } \\
\text { ness associated } \\
\text { with petals and } \\
\text { gel }\end{array}$ & $\begin{array}{l}\text { Simplicity } \\
\text { and preci- } \\
\text { sion create a } \\
\text { subtle com- } \\
\text { position }\end{array}$ \\
\hline
\end{tabular}

TABLE 1 - Formal and chromatic analysis of the different compositions 


\subsubsection{Results, evaluation and discussion}

Humans have limited attentional capacity, and vision tends to capitalise on the available neural resources. As a result, often not much attention is paid to the other senses. Indeed, more often than not, what is seen ultimately determines what is perceived, even when the other senses may be sending to the brain a different message [147]. On the other hand, when it is not possible to rely on sight, other senses are encouraged to work harder, therefore, enhancing and challenging the food perceptions.

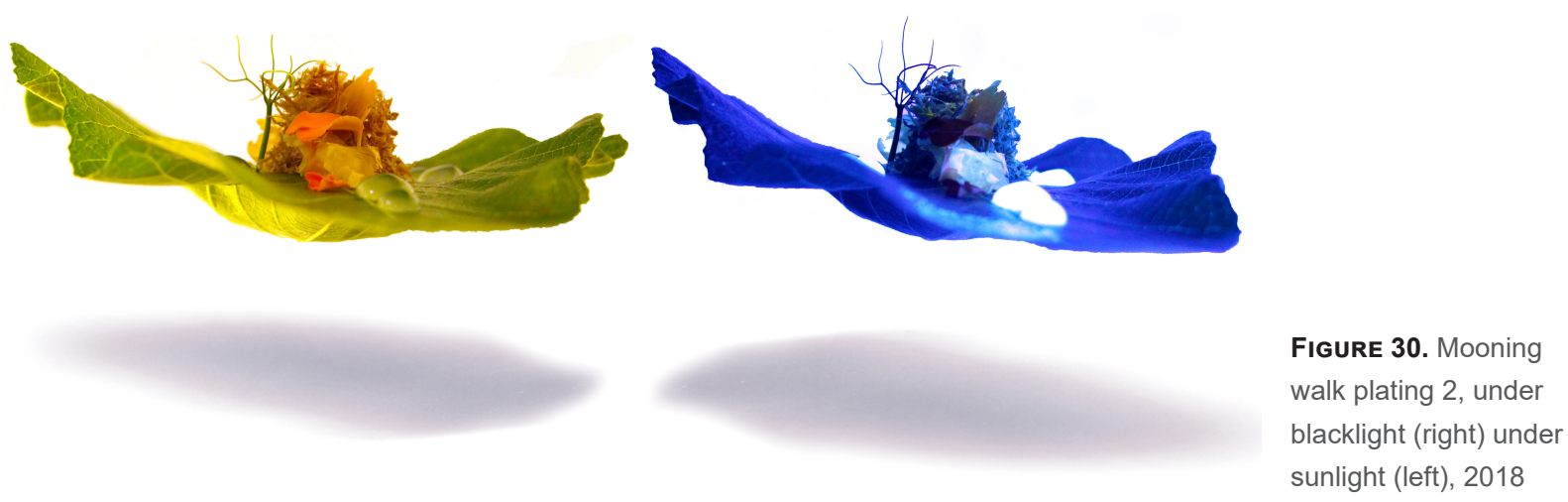

Technology was here used to facilitate the building of a multisensory dining experience although there is the risk of this becoming more important than the food itself. In fact, thinking more strategically, it could be argued that such technologies will only stick in the marketplace if they are capable of providing a demonstrable benefit in terms of enhancing the diner's multisensory experience. As mentioned before (see Chapter 4.4.4), H. Blumenthal dish 'The sound of the sea' is an example in which digital technologies can be used to deliver a genuinely different kind of multisensory dining experience. In this case, it is also expected that the diner ends up by getting to pay more attention to dish and this results in an increased perception [88].

Some restaurants have recently started to experiment the possibilities associated with projecting images directly onto the food sitting on the dinner table. For example, at El Celler de Can Roca in Spain [57], a variety of projections over the food dishes give the impression of bringing the food very much to life [88].

The use of the magnetic levitation system and the fluorescence in this dish, as its technologies content, aimed to create an impact on sensory perception, mark the memory by a different experience as being innovative, create interest, arouse curiosity and involve emotions. Constant feeling of surprise, based on the delivery of unusual sensory experiences, that may really make this dining experiences so unusual and intriguing for the customers [147].

A study with sensory analysis should have been carried out in order to understand the role of the elements above described on the impact of the dish. However this was not possible in the scope of this dissertation.

Mostly food is eaten from round white plates, as the plate here used is a triangular green leaf, this could be the first detail to focus on. Plating does not stop with the choice of plate, but extends to the complexity of the overall arrangement on the plate and the interactions between the various visual attributes of plateware [130]. Apart from the organic edges, a leaf inserts its own lines on the plan, symmetry and perspective to its composition. Comparing a real leaf to a white round plate is certainly a non-coherent evaluation. 
Figure 31. Mooning

walk plating 2 , under

blacklight (left) under sunlight (right), 2018
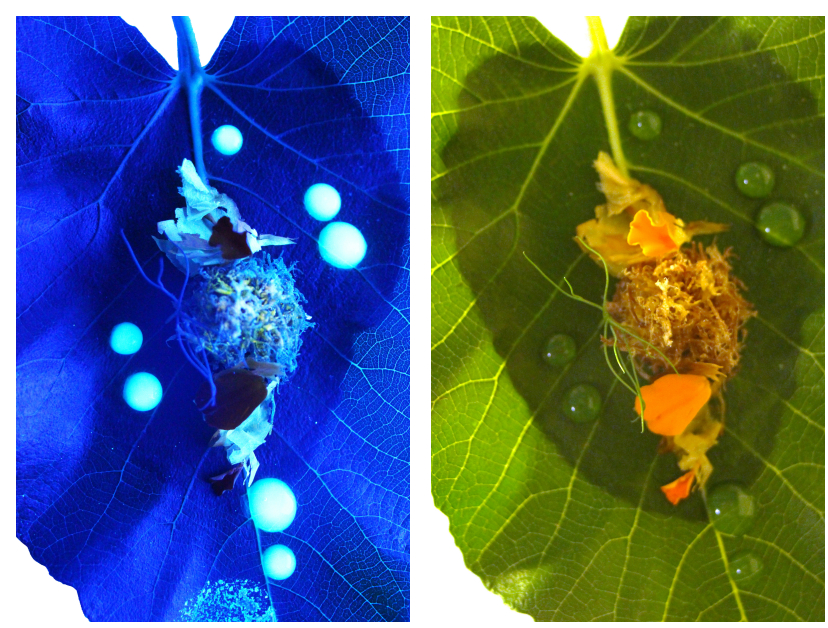

As Deroy \& Spence (2016) quoted in triangle-like shapes, orientation appears to matter, with downward pointing triangles being associated with a threat, the fig's leaf assumes this shape. However, the plate was in constant rotation so no upward or downward orientation was defined. MICHEL ET AL. (2015) affirm that optimally orienting the plate translates into an increased willingness to pay for the food, demonstrate that orientation matters, so movement provided by the magnetic levitation gives continuously different readings as the base is unceasingly rotating.

Another feature of visual cues is colour, the characteristic that most contributes to create expectations regarding on what is going to be eaten [140]. These have different meanings as do visual textures, temperatures, shapes, angles and even the distance between foods. Colour announces temperature as tendency for yellow (hot pole) or tendency for blue (cold pole) [101], [103]. According to colour psychology blue is seen as sour, bitter, salty, "citrusy", "syrupy" and accentuates crunchiness [124]. According to this information when blacklight is on the dish it can be perceived as colder, sour, bitter, and more salty, citrusy, syrupy and crunchier than under normal light. Although, a study must be done to confirm it. This empirical question is particularly relevant given that the visual appearance of most foods and drinks does not include only a single colour. Instead, they involve various visual characteristics with different ranges of hue, brightness, and saturation. Therefore, it can be hypothesized that multiple colour cues, if chosen appropriately, may provide more information when inferring a specific taste quality. For instance green stimulus with a red border most often links with sour, salty (white + blue), and sour (green + red, red + yellow) [144]. Back to the single colours, brown is another dark colour that tends to make people not feel very hungry. Brown reminds people of food that has been overdone or burnt. Besides the colour of the plate may affect the perceived colour of the food by means of the well-known phenomenon of colour contrast, an object seen in the foreground appears to have a different colour (or contrast) depending on the colour of the background [130].

After all, it could be argued that complexity depends on much more than merely just the variety of colour that happens to be present in a dish. It also depends on the size of the elements, the variation in colour, the number of products, the familiarity of the person with those products, and the mix of products or elements that are involved. It is important to underscore the fact that the texture and material from which the plate is made may also exert an influence on the visual appearance of the overall dish: a textured plate (incorporating shading and distinctive shapes) may give rise to more complex patterns of colours. Different materials and coatings (for example, shiny versus matt) might also be expected to change certain characteristics of the colour. Controlling for these additional aspects is certainly a challenge for the comparability and generalization of the few scientific studies that have now started to appear where the differences induced by changing the colour of the plate or container in which the same food or dish is presented have been studied [130].

The non-existing cutlery when tasting this dish, due its magnetic interference, also introduces different perception components. It can be reminded that many people around the world eat without the aid of cutlery, and claim their food to be much tastier [132]. 


\subsubsection{Conclusion}

While the use of technology in this domain certainly holds the potential to enhance the diner/drinker's experience, or to allow a restaurant to differentiate itself in the challenging world of fine dining, it is important to remind that it can also provide an unwanted form of distraction. The dish just described - Moonlight Walk, certainly has an important component of surprise. On the other hand, though, altering know visual cues can allow dinners to concentrate more on the taste and aroma of food and drink. Digital technologies will constitute an increasingly common feature of the dining table of the future [88], contributing to allow people to control/modify their eating behaviours and perception, in order to improve it. In summary, the range of scientific insights that are now available concerning the effects of the multisensory atmosphere on the pleasantness and enjoyment of food can be used, potentially giving it a purpose in terms of enhancing the diner's experience, rather than just serving to offer the diner an entertaining distraction [88].

There is a growing public interest in the topic of food aesthetics. The logic is that the science of plating, or rather the scientific approach to aesthetic plating, will continue to grow in the years to come [164]. Culinary schools should therefore consider teaching certain basic principles of art and aesthetics, as an integral part of the skills that any chef should have [121]. It has been difficult for Food Design assume a role of subject at culinary arts school, even though Design With Food should be contemplate as topic [85]. 


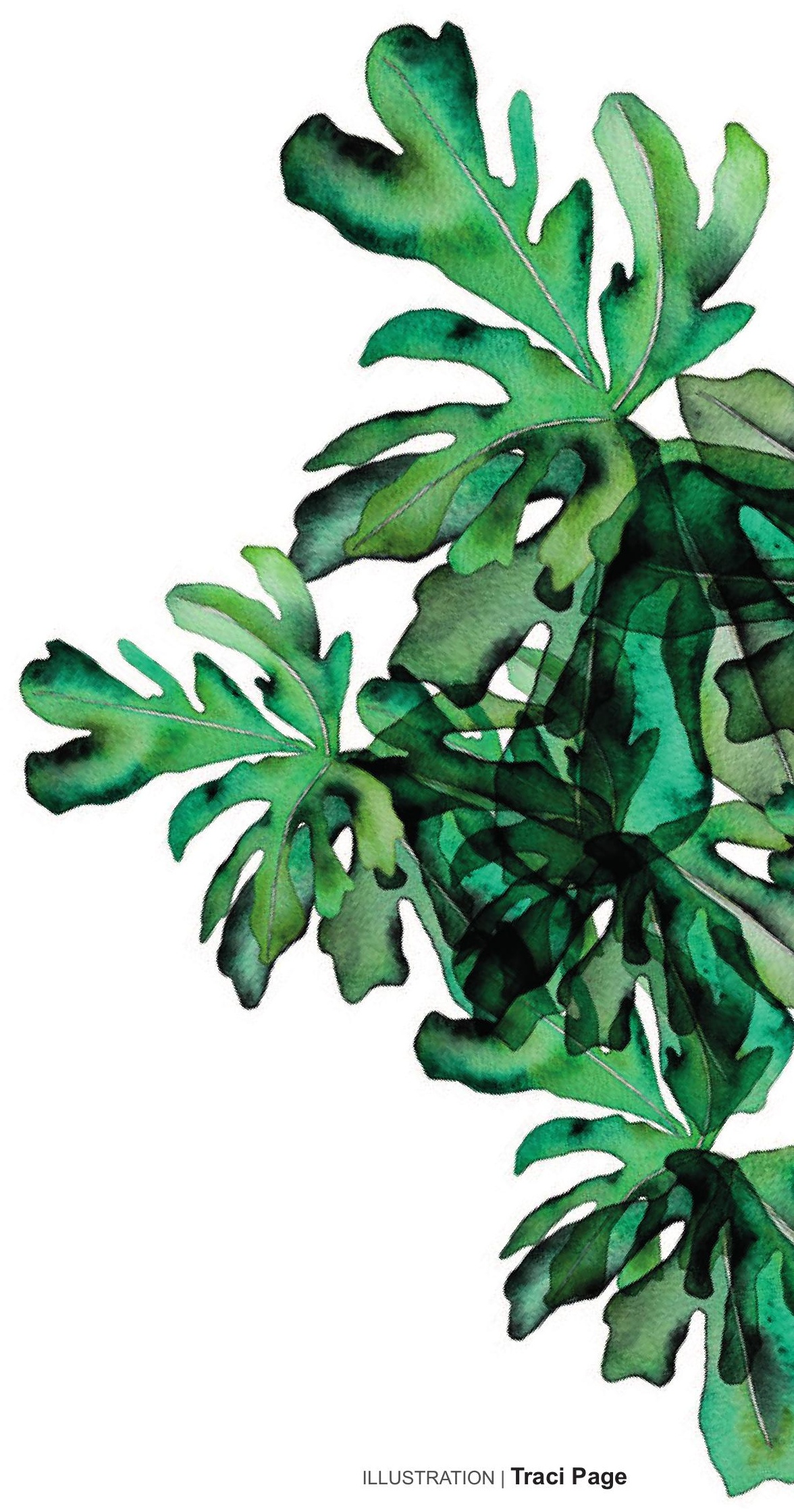




\subsection{SMELL}

\subsubsection{Objectives}

The sense of smell is the ability to detect volatile chemical molecules (usually of low molecular mass) [124]. There is still much to be studied, about the sense of smell as "the number of discriminable smells may be much closer to one trillion" [173], [174]. Between 75 and $95 \%$ of what is commonly considered as flavour really relies on the information transduced by the nose [134], [175], [176].

Apart from the smell of the food, extra olfactory elements can be used to change or enhance its perception as: atomizers used to spray over the meal or even over the customer, smoke-filled containers, airfilled pillows with aromas, organic elements like leaves or wooden cutlery, Aromafork $®$, porous ceramic spoons that release aromas, dry ice and liquid nitrogen diffusion, Vaportini®, rotary evaporators, etc, [101], [177]. It is also important to understand how aromas behave and are perceived in containers with different designs, in order to efficiently take advantage of the olfactory system.

The famous axiom by Louis Sullivan (1856-1924) "form follows function" means that the purpose of an object should be the starting point for its design [55]. Tasting a dish is not only a flavour experience but involves also an additional vivid sensory experience of shape in mind's eye, or perhaps "feel" the shape in mind's hand instead, speaking of memories and emotions. Shape symbolism, related to tastes and flavours is an aspect that has already been studied [137]. Previous experiences show that shape induce expectations and can influence taste perception [178]. Shape symbolism can therefore be seen as a specific form of cross-modal correspondence.

Olfactory perception of food can be dramatically affected by the way it is presented and particularly by the design of the containers. The aim of the present study was to develop a container, using a design process, based on a literature review and psychophysiology knowledge, in order to optimize the sensory perception of the food and improve the global experience.

The development of the containers, the food used for the research and the sensory analysis was done at La Masia (R\&D department) at El Celler de Can Roca.

This study resulted in a paper that was presented on the 19th of October 2017 at the 1st International Conference on Food Design and Food Studies: Experiencing Food and Designing Dialogues, at Faculty of Architecture of the University of Lisbon and that was later published in the Proceeding of the conference [2].

\subsubsection{Dish Composition}

A set of 6 elements compose the starter, called as Drinkable Smoke, representing all the morning aromas coming from roots, earth, woods, flowers and vegetables. The main elements of the dish are roasted celeriac cream, smoked coconut milk and apple jam. The main flavours in the developed dish can be characterized as vegetal, herbaceous, citrus, sweet, earthy, spicy, woody, fruity and smoky. By descending aromatic order of intensity, celeriac, smoked coconut milk, grilled apple and coriander, are the aromas perceived when eating the dish.

Celeriac was chosen as the main ingredient of this dish. Celeriac, Apium graveolens var. rapaceum, is mostly used as a vegetable or for seasoning and is valued for its rich nutritional and medicinal properties, and also for its pleasant spicy, herbal and dry aroma, and sweet and bitter taste. 
After some trials of food pairing, coconut milk was used due to its herbal and fruity aromas, creaminess, softness and excellent food pairing with celeriac, imparting a satisfactory balance.

Golden apples grilled using pine coal were also used. The apple skin worked as a natural coat during the grilling process which allowed to keep most of the volatiles of the bio apple in its own matrix, and also to add notes of smokiness.

FIGURE 32. Drinkable

Smoke in bottle dish,

Vista Alegre, 2018.
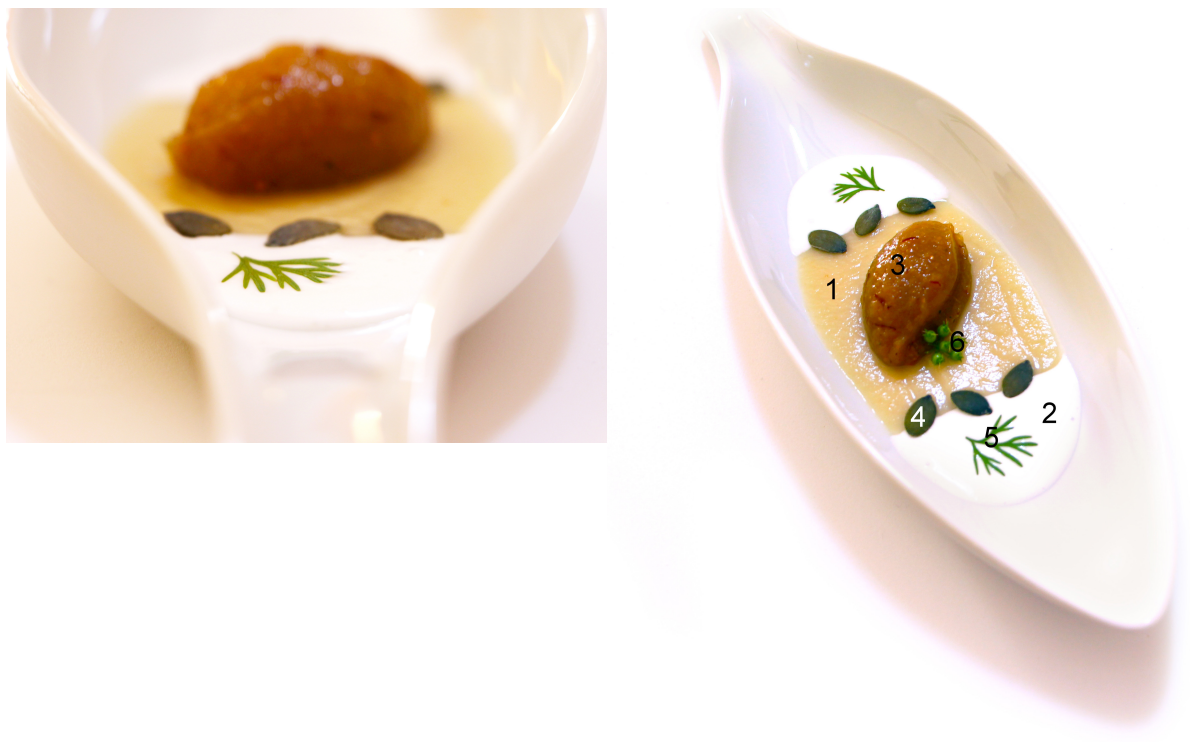

Green mandarin and ginger food grade essential oils provided by Organic Skin Food® were applied in the celeriac purée in order to enhance the olfactory perception and to pair with the aromas already present. Several tests were made to define the right concentrations. The mandarin essential oil matches the limonene of the celery [135] and the ginger oil flows with the earthy and spicy flavour of the purée.

1 - Roasted celeriac cream pureed with rice milk and butter, aromatized with green mandarin and ginger essential oil. It is served hot and has the texture of a vichyssoise. The butter gives some greasiness to fill the palate.

2 - Coconut milk smoked with lavender. Served at $45^{\circ} \mathrm{C}$.

3 - Grilled golden apples. Lightly sweetened and texturized with pectin to get the texture of a jam. The whole apples were charred on direct contact with pine coal and then were peeled, blended and boiled with pectin. Served at $45^{\circ} \mathrm{C}$.

4 - Pumpkin seeds slightly toasted to give crunchiness to this fluid dish.

5, 6 - Coriander leave and green seeds to add vegetal freshness notes on olfactory perception. 


\subsubsection{Techniques applied}

Producing an olfactory dish requires culinary techniques in order to retain, enhance or introduce aromas in a controlled way and according to the aims.

\begin{tabular}{|l|c|l|l|l|l|l|}
\hline TEXTURIXERS & NUMERATION & $\begin{array}{l}\text { WHERE } \\
\text { APPLIED }\end{array}$ & $\begin{array}{l}\text { CONCENTRA- } \\
\text { TION }\end{array}$ & $\begin{array}{l}\text { RHEOLOG } \\
\text { ROLE }\end{array}$ & $\begin{array}{l}\text { T}^{\circ} \mathrm{C} \text { OF APLI- } \\
\text { CATION }\end{array}$ & $\begin{array}{l}T^{\circ} \mathrm{C} \text { OF } \\
\text { STORAGE }\end{array}$ \\
\hline SUCRO & 1 & $\begin{array}{c}\text { Celeriac } \\
\text { Purée }\end{array}$ & $0,12 \%$ & Emulsifier & $35^{\circ} \mathrm{C}$ & $5^{\circ} \mathrm{C}$ \\
\hline XANTHAN & 2 & $\begin{array}{c}\text { Coconut } \\
\text { Milk }\end{array}$ & $0,67 \%$ & Thickerner & $3^{\circ} \mathrm{C}$ & $5^{\circ} \mathrm{C}$ \\
\hline PECTIN NH & 3 & Apple Jam & $2,17 \%$ & Gellifier & $\begin{array}{c}\text { Dispersed at } \\
\text { room tem- } \\
\text { perature and } \\
\text { heated to } \\
105^{\circ} \mathrm{C}\end{array}$ & $7^{\circ} \mathrm{C}$ \\
\hline
\end{tabular}

TABLE 2 - List of texturizers and characteristics of its applications

\section{1| Celeriac purée}

Roasting the celeriac without removing the peel and wrapping it with aluminium paper foil, intended to preserve the moisture and the volatiles. Furthermore cooking it at $160^{\circ} \mathrm{C}$, for 4 hours allows to obtain the right consistency and flavour [7].

Celeriac tastes much like celery thanks to the same oxygen-ring aromatics and contains a moderate amount of starch (5-6\% by weight). It is usually cooked like other root vegetables [7]. Each vegetal or root has its own structure of fibers, rupture of its matrix by cooking, smashing or blending will better release all the flavours.

Essential oils are generally obtained by either steam/water distillation, expression extraction, or solvent extraction. The Ginger Essential Oil (Zingiber officinale Roscoe) used was obtained by steam distillation of the rhizome. This process is carried out in a distiller using water vapor to facilitate the release of the essences from its secretory or storage cells, its extraction, and isolation by phase separation [179]. The dry rhizome of ginger usually yields about 1 to $4 \%$ of the light yellowish essential oil which is characterized by its distinctive and strong pungent smell. Representative chemical composition of the ginger oil isolated by steam distillation includes the following major components: $\alpha$-pinene, camphene, $\beta$-pinene, sabinene, $\Delta$-3-carene, myrcene, $\beta$-phellandrene, limonene, tricyclene, zingiberene, 1,8-cineole, borneol, zingiberol, methyl heptanone, citral, $n$-decylaldehyde, linalool, geraniol, farnesene, curcumene, and bisabolene [180].

The Green Mandarin Essential Oil (Citrus reticulata) was obtained by cold-pressing extraction from the citrus peel. The expression method is applied exclusively to the fruits of species belonging to the genus Citrus (bergamot, orange, lime, lemon, tangerine, grapefruit) that present their essential oils in bags in the pericarp. The outer layer of the skin is lacerated through a mechanical process and the essence pressed out [179].

The oils of the Portuguese brand ii - Organic Skin Food are obtained exclusively by organic farming, without any traces of synthetic pesticides that contaminate them and without the use of solvents in their extraction. 


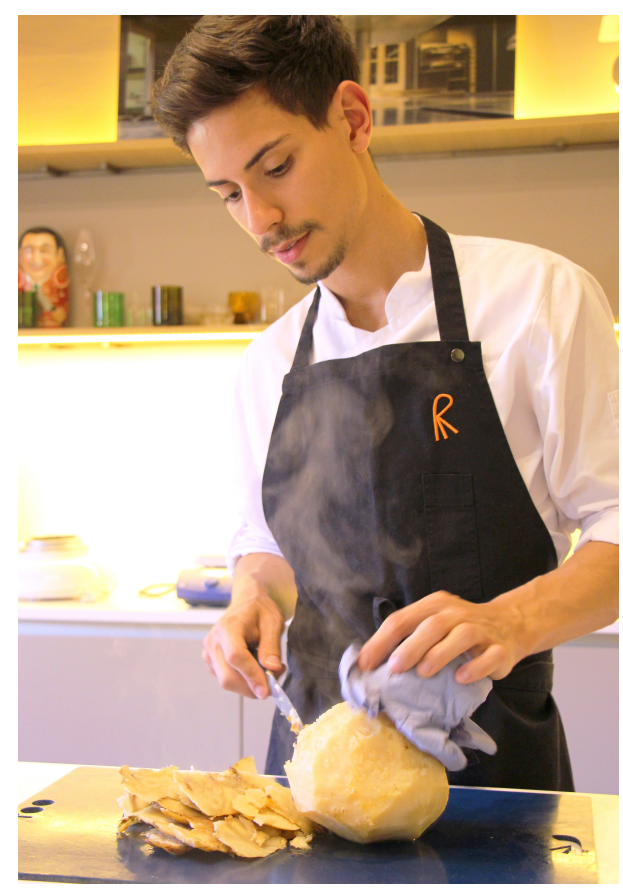

\section{2 | Coconut milk}

Xanthan gum, which has a good flavour release, was used to thicken coconut milk, and provide a rich creamy mouth feel. For further details about this hydrocolloid see chapter 7.5. Also see table 2 for access of information

Lavender (Lavandula dentata) is a Mediterranean plant long and widely valued for its tenacious floral-woody perfume (from a mix of flowery linalyl acetate and linalool, plus eucalyptus-like cineole). The dried blossoms are a traditional ingredient in the mixture herbes de Provence (along with basil, rosemary, marjoram, thyme, and fennel). It is also useful alone, when used discreetly, as a garnish or to infuse their qualities in sauces and sweets [7]. Lavender was dried in a Excalibur dehydrator for 10 hours at $50^{\circ} \mathrm{C}$, then was burned in order to smoke the coconut milk.

Figure 34. Preparing the celeriac purée, Joana Pedret, 2018

\section{3 | Apple jam}

Grilling the apple without removing the peel in direct contact with charcoal enhances the flavour as cooking it at high temperature, approx. $500^{\circ} \mathrm{C}$, for 30 minutes increases Maillard reactions and caramelization processes [7].

Pectin is a polysaccharide constituent of the cell wall of dicotyledonous plants. The association of pectin between cellulose and hemicelluloses gives rise to protopectin in plant tissues. The protopectin, of an insoluble nature, is readily hydrolysed by heating, in acidic medium, to form pectin. The extracted types of pectin have different characteristics (degree of esterification, particle size, sugar content, ash content and others) and consequently have different functional properties [181]. The gelation temperature of pectin $\mathrm{NH}$ is in the range of 30 to $70^{\circ} \mathrm{C}$, which is why it is added to the still warm mixture. Under low $\mathrm{pH}$ conditions, esterified chain sequences are capable of forming stable associations at higher temperatures that are stabilized at lower temperatures [86]. Obtained from citrus fruit peels $\mathrm{NH}$ variety pectin is a form of low methoxyl pectin processed to be thermally reversible and to form gels in the presence of calcium. The addition of citric acid which has a mild taste and is long-lasting, enhances fruit flavours, improves $\mathrm{pH}$ stability, works as a preservative [135].

\section{5 | Coriander}

One of the main components of the aroma of the coriander leaves is (E)-2-decenal, which also provides the "waxy" note in orange peel. (E)-2-Decenal is very reactive, so coriander leaves quickly loses their aroma when heated. Coriander is therefore used most often as a garnish or in uncooked preparations [7].

\subsubsection{Plate Design}

Aiming to design the physic containers to use on the current study a design process was established taking into account the available resources. The Roca Recicla $®$ project, consists in the reuse of part of the glass waste of the restaurant El Celler de Can Roca transforming it into flatware and supports for the restaurant and other projects. 
In order to evaluate the influence of the plate in the perception of aroma, several drafts of possible plates, with different characteristics, were developed. With the help of Elena Portillo, responsible for the

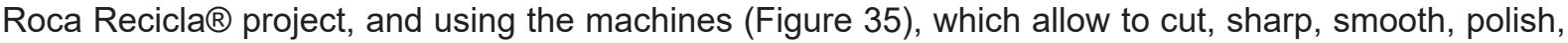
scour, sand, melt and attach glass, it was possible to produce real glass pieces, and optimize them until the intended characteristics were achieved. Three different containers (table n. 3) made with non-coloured fizzy recycled glass were created. The reason for the material chosen for all the containers to be fizzy recycled glass, apart from the Roca Recicla ${ }^{\circledR}$ sustainability brand image, was because it was considered that these characteristics reduce the impact on the other senses, thus allowing to focus the sensory analysis preferentially on the olfactory sense. In fact, the colour will not induce cross-modal correspondences and the opacity of the containers and the lids reduces the tasters previous expectations.

One was a half fizzy bottle, covered with an organic shaped lid made from a Siemens ${ }^{\circledR}$ glass oven with irregular bottlenecks holes. Another a common transparent bowl covered with a fizzy glass campanula. The third container was a recovered broken balloon glass, having a fizzy inside obtained using a Pallinatrici Norblast $₫$ machine.

Sensory analysis tests were performed in order to evaluate the effect of the three containers in the perception of aroma.

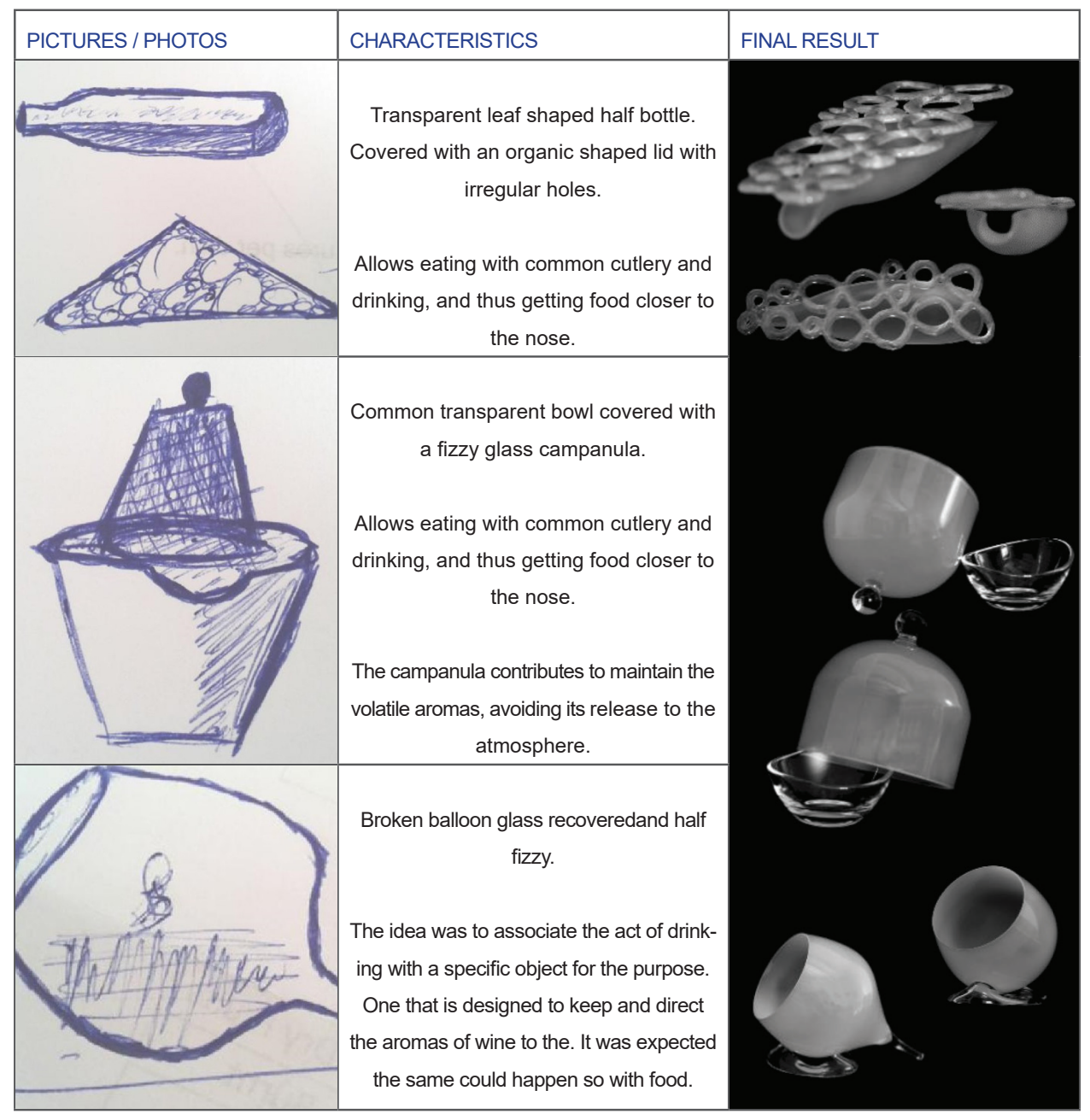

TABLE 3 - Drafts and the final glass containers 
Subsequently, the author got an invitation by International Design Pool from Vista Alegre Atlantis $®$, Portuguese company of tableware, decorative, and barware, specialized in crystal and ceramics, to their Design Residency. The objective was to design a plate based on the results from the study performed. If approved by the commercial, production and design departments a new plate could be added to the Chefs' Collection range of plates. This product line consists in designing new plates intended for fine dining.

Founded in 1824, the Vista Alegre Porcelain Factory was the first industrial unit dedicated to producing porcelain in Portugal. The persistence of its founder, José Ferreira Pinto Basto, was instrumental to the launch and success of this enterprise, located in Ílhavo in the district of Aveiro. In 1829 Vista Alegre gained the title of Royal Factory in recognition of its artistry and industrial success [182]. In May 2001, a merger between the Vista Alegre Group and the Atlantis Group brought glassware and crystal back to the company and resulted in the largest tableware group in Portugal and the sixth largest group in the world within this sector, annually producing, about 15 million pieces in porcelain, crystal and glass, in the tableware, decorative, and bar segments, and exporting to more than 70 countries. Vista Alegre is more than a mere indus trial unit. It is also part of the Portuguese heritage,, and a repository of social and artistic memories essential to building a Portuguese identity [182], [183].

The aim of the two weeks at Vista Alegre Artistic Residence was designing one or two pieces of porcelain intended of being included in the Chefs' Collection. This means coming out of the authors comfort zone, andwas challenged as equipment, required knowledge and techniques, among other aspects, are quite different from the environment that exists inside a kitchen. However, the similarities between the creation of a dish or recipe and the design of a piece of porcelain were remarkable [64], [184].

Figure 35. Roca

Recicla machinery,

2018
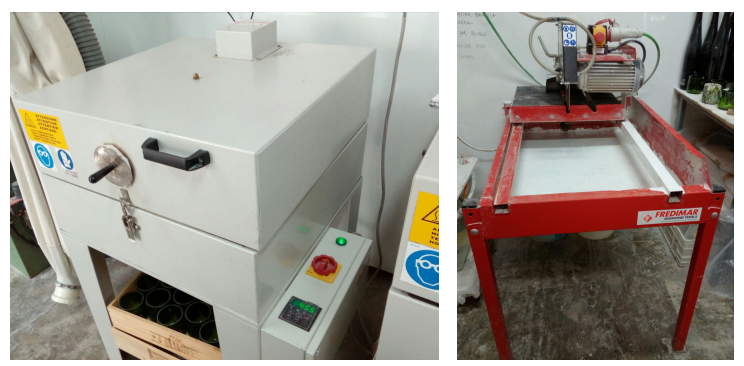

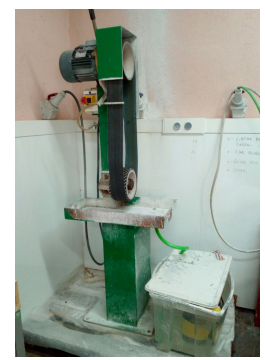

It was the first time a cook participated in Vista Alegre artistic residences and the the time for the project very limited, in fact such type of projects usually take much longer. For all these reasons it was an important challenge.

The whole project related to this dish involves several areas, such as neurosciences, gastrophysics, cooking, product design, product development, etc.. In fact, a successful design process requires important interdisciplinarity. Mutual cooperation between all the participants of the artistic residence specialized in different areas and teamworkand sharing were decisive to accomplish the design creative process. This whole experience contributed was extremely valuable.

A double diamond design process was established (Design Council, 2017):

\section{$1^{\text {st }}$ Phase - Discover}

It is intended to apply results from a previous study and produce plateware that respects and enhances olfactory perception.

Using the creativity brainstorming technique, ideas were generated to apply the results previously obtained and produce something new and with innovative characteristics. 


\section{$2^{\text {nd }}$ Phase - Define}

Converge ideas, ponder options, circumvent production barriers and adapt to manufacturing constraints.

Drafts and product design were done at this phase. The software used for technical design and 3D perspectives were Rhinoceros Version 4.0SR9 and V-Ray Render (plug in). The aid of the Senior Designer Richard Williams was essential at this stage of the design process. The evolution from drafts to 3D prototypes are presented at Figure 36. Larger illustrations are available in the appendix 10.8 .
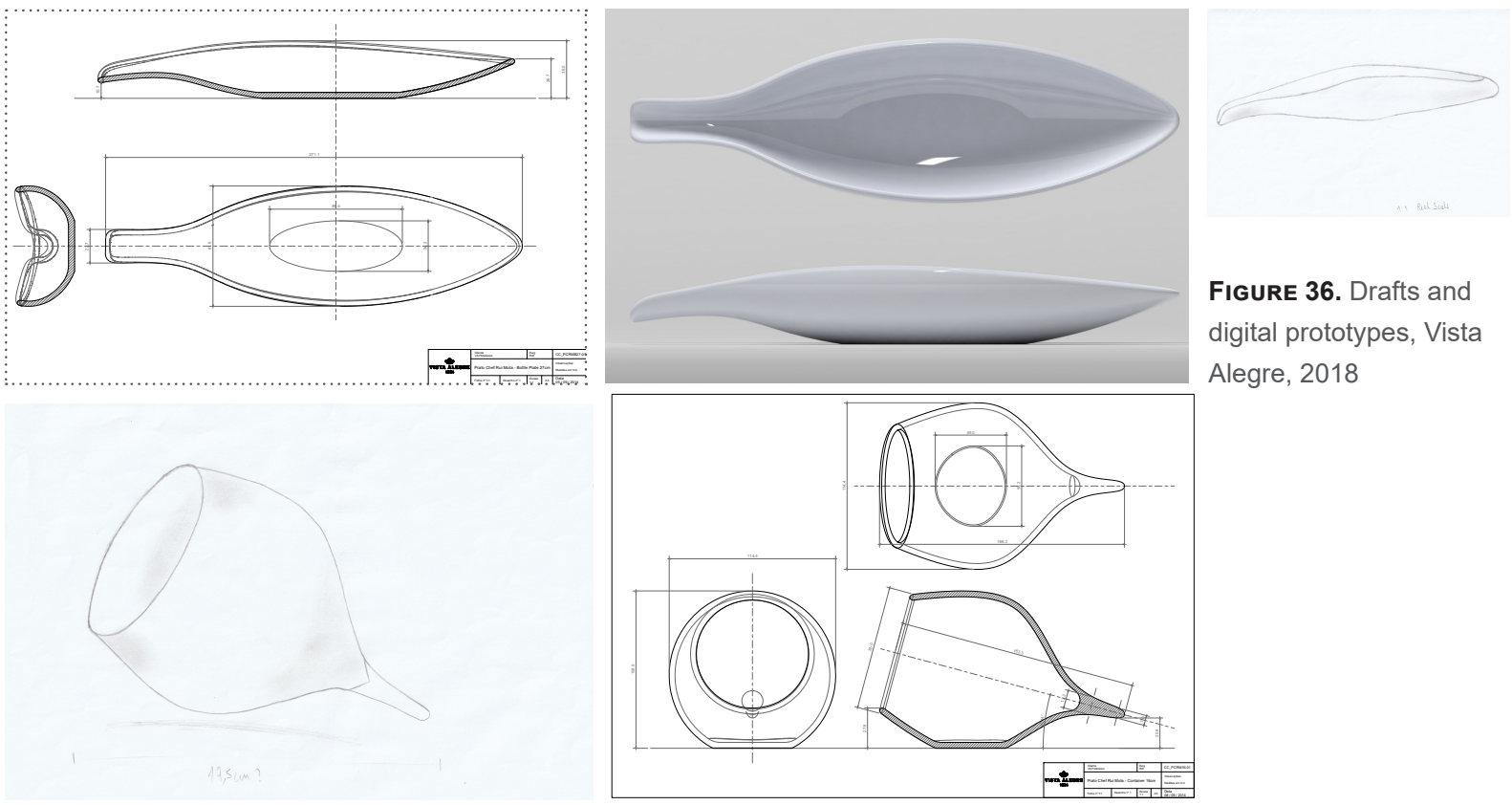

FIGURE 36. Drafts and digital prototypes, Vista

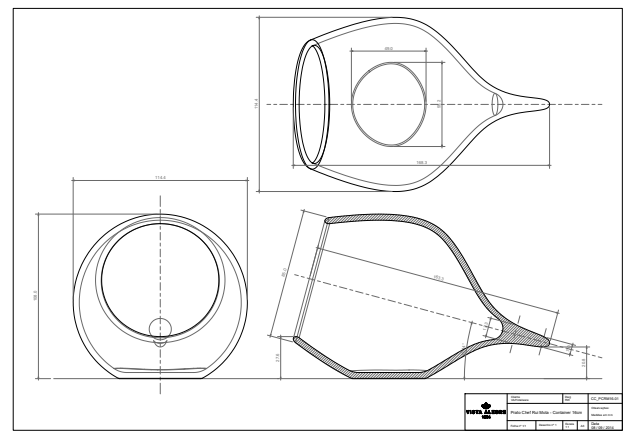
Alegre, 2018
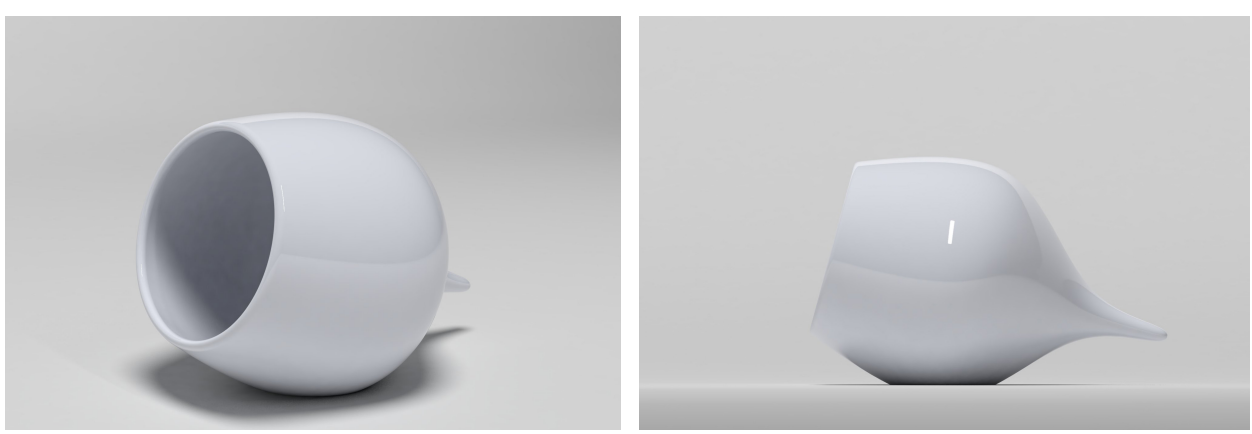

\section{$3^{\text {rd }}$ Phase - Develop}

Prototypes were tested in plaster molds, the process involved a trial and error methodology by slip casting at modulation department with the supervision of Madalena Esteves and Abílio Aires. Ajustaments were made following suggestions by New Products Engineers Carla Castilho and Sousa Bastos, improving and refining ideas in order to avoid cooking ceramics issues.

\section{$4^{\text {th }}$ Phase - Delivery}

After the conclusion of the design process it was decide that the bottle plate had a better potential to be produced in large scale and commercialized. It was considered as being a potential best seller because it allows different compositions on the table, is is easy to pile and elegant, even though it was not the one with the best performance in the sensory study described below. 
The process is complete and the plate is already being produced in biscuit and launched in the market.

The bottle plate is produced by high pressure casting. Following several steps: drying stage, finishing and trimming, cooking cycles ( $\mathrm{F} 2-6$ hours) at $980^{\circ} \mathrm{C}$ and another one at $1400^{\circ} \mathrm{C}$ ( $\mathrm{F} 4-6$ hours), quality control, stamping, packaging and distribution.
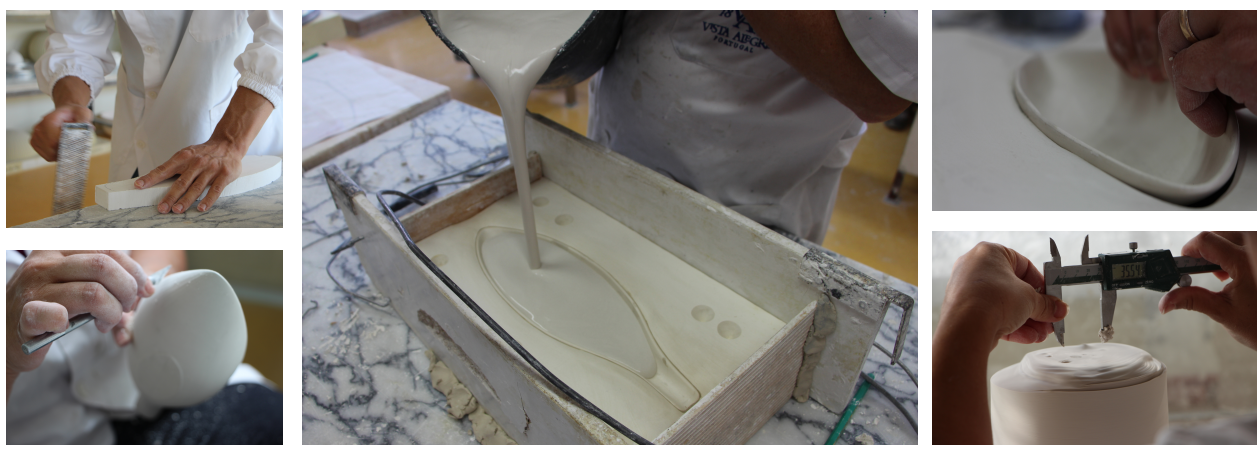

FIGURE 37. Modulation process, Vista Alegre, 2018
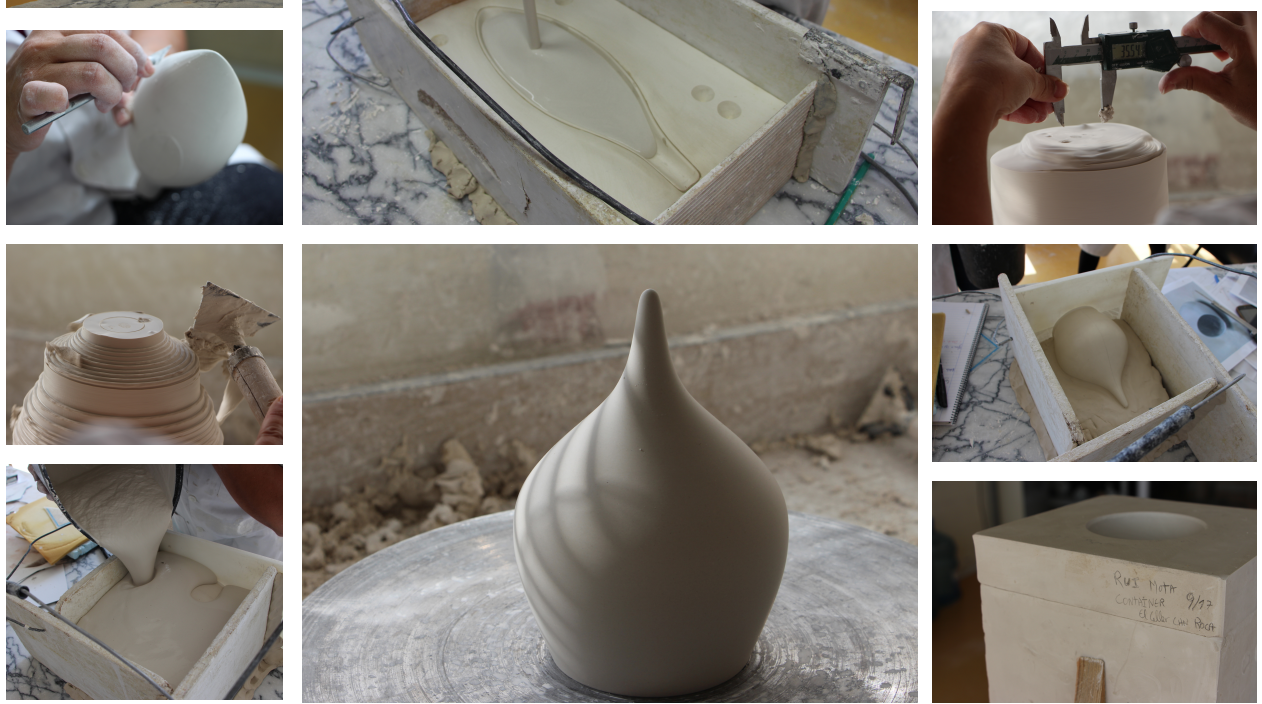

The glass plate is undergoing further modifications as some problems were identified by the commercial department. It was considered as being fragile due to its stem and difficult to pile. These aspects could be seen as problems to buyers, limiting his commercial viability although it was the plate with the best performance in the study described in the following chapter.

\subsubsection{Sensory Evaluation}

The current study investigates if the presentation of a dish in containers with different designs and characteristics has a significant impact on the perception of the dish, particularly in the perception of aroma and smell. In order to evaluate the different containers a sensory analysis was implemented. Only the celeriac purée was used as sample for the test of the containers. The rest of the elements in the dish were not used to focus the attention of tasters on the evaluation (see figure 38, and 10.6 for sensory analysis from).

Participants were thirty-three volunteers, without any food intolerances, allergies or taste and smell related diseases, belonging to the staff of El Celler de Can Roca, Girona. This group of tasters was composed by 18 males and 15 females. aged between 19 and 56 (mean 29,5 years, standard deviation 9,8 years). Although these were non-trained tasters, they can be considered experts as they work in the restaurant and are familiar with food tasting and ingredients.

Participants were asked to restrain from eating for at least half an hour before the tasting. The tasting was done in a room, away from the production zone, with a temperature of $24^{\circ} \mathrm{C}$. Natural mineral water was available for mouth cleaning between samples. The roasted celeriac cream samples $(90 \mathrm{~g})$ were warmed in a water bath at $45^{\circ} \mathrm{C}$ and equally divided between the three containers. The food was plated 20 seconds before tasting. According to Macfie \& Bratchell (1989) a random tasting order was established for the containers. A quick introduction was made to each taster and they were not informed that the samples were identical. 

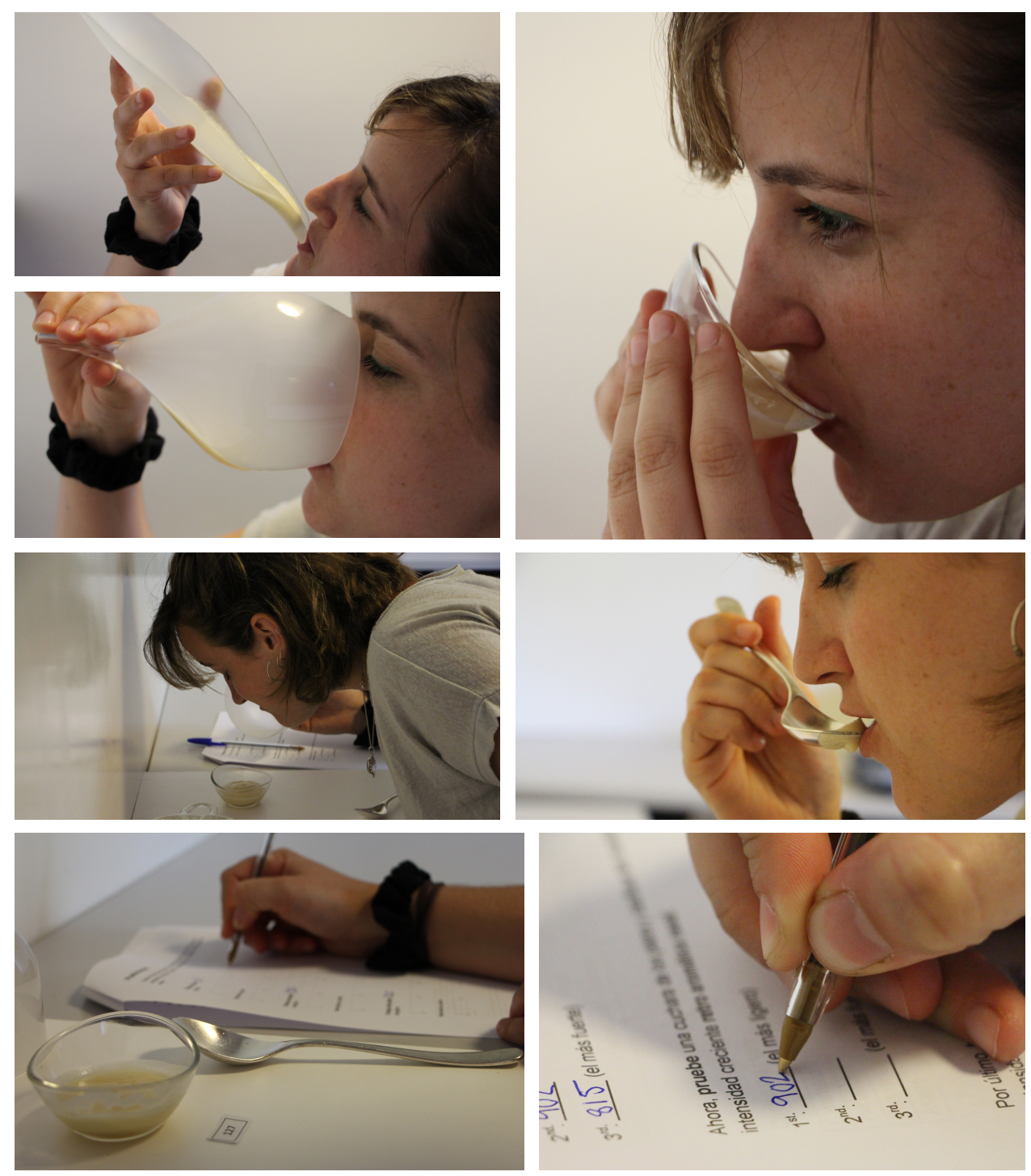

FIGURE 38. Sensory

Analysis, 2018

Three tests were sequentially performed 1) a ranking test ISO 8587:2006 [185], in which tasters had to order by the intensity of smell/aroma samples, perceived in three different situations: sniffing without tasting, eating using a silver spoon and drinking a sip; 2) tasters were asked to pick from 20 aromatic characteristics the two that better described each dish; 3 ) tasters should apply a structured numeric scale test ISO 4121:2003 [186], of 10 values, for measuring essential oils intensity. The tasters forms are available at attachments (Annex 10.3.).

\subsubsection{Results}

In order to detect if the design of the containers had a significant impact on the perception of this dish, particularly in the perception of aroma and smell, a nonparametric analysis (Friedman) was performed. Whenever the results revealed significant differences, the Multi Mean Comparisons were made using Wilcoxon Signed-Rank test to identify the differences. For the second test the principal component analysis (PCA) method was used to identify the most relevant characteristics of each dish. Differences were considered significant when $p \leq 0,05$. Statistical analyses were performed using IBM SPSS Statistics GradPack 24 and XLStat. 
Figure 39. Mean

scores of the perceived intensities of smell by sniffing, and of aroma by tasting using a spoon and drinking a sip.

Note: For similar characters the ranks are similar, for a $\mathrm{p} \leq 0.05$.

* identifies significant differences as measured with Tukey's and Wilcoxon, $\mathrm{p} \leq 0.05$.

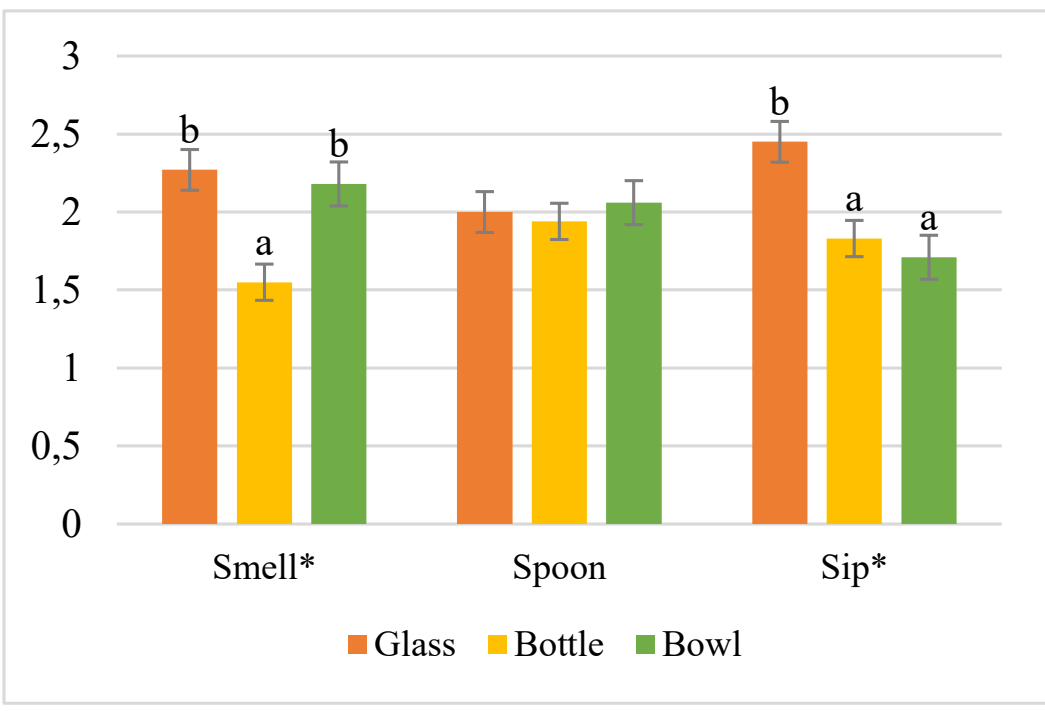

Considering the ranking test, the intensity of aroma and smell was perceived as significantly different for some samples: in the glass and bowl the smell perceived by sniffing was perceived as significantly more intense than in the bottle $(M=2.27$ and 2.18 vs. $1.55, p \leq 0.05)$; the aroma perceived when drinking a sip was more intense in the glass in opposition to the bowl or bottle $(M=2.45$ vs. $1.711 .83, p \leq 0.05)$; and when using a spoon the differences did not reach significance $(M=2.00$ for the glass, 1.94 for the bottle, 2.06 for the bowl, $p \geq 0.05$ ) as the interaction plot in Figure 39 illustrates.

For the second test, the aromatic characterization of the dish served in each container, the Friedman analysis shows that there is a significant difference of $p=0.043$ among the features. This statistical significant difference was specified by Wilcoxon analysis. The value is lower for the glass relative to the bottle and bowl ( $M=1.62$ vs. $2.312 .07 \mathrm{p} \leq 0.05)$.

With PCA a biplot chart was obtained (Fig. 40) that reveals which features were the most significant ones correlated to each container. The bowl is associated to Vegetal ${ }^{\mathrm{a}}$, Herbaceous ${ }^{\mathrm{b}}$, Citrus $^{\mathrm{c}}$ and Sweet ${ }^{\mathrm{d}}$; the bottle to Earthy ${ }^{h}$, Spicyi, Fruityj, Fermented ${ }^{k}$ and Woodym; for the glass the characterization was not coherent, consequently it is not significant, however the profile graph (Fig. 41) shows that it is related to Citrus $^{c}$, Floralg and Smoky ${ }^{q}$.

FIGURE 40. Biplot

(axis F1 and F2: $95,39 \%)$ made as a result of PCA method

to evaluate from all the features (Vegetala Herbaceous $^{b}$, Citrus ${ }^{c}$, Sweet $^{\mathrm{d}}$, Butterf, Floral $^{9}$, Earthy ${ }^{h}$, Spicyi,

Fruity', Fermented ${ }^{k}$,

Caramel', Woody ${ }^{m}$, Roast $^{n}$, Nutty $^{\circ}$,

Chemical $^{p}$, Smoky $^{q}$,

Dry Fruitr, Rancids,

Pungentt and Burnt ${ }^{4}$ ), which were more associated to each container.

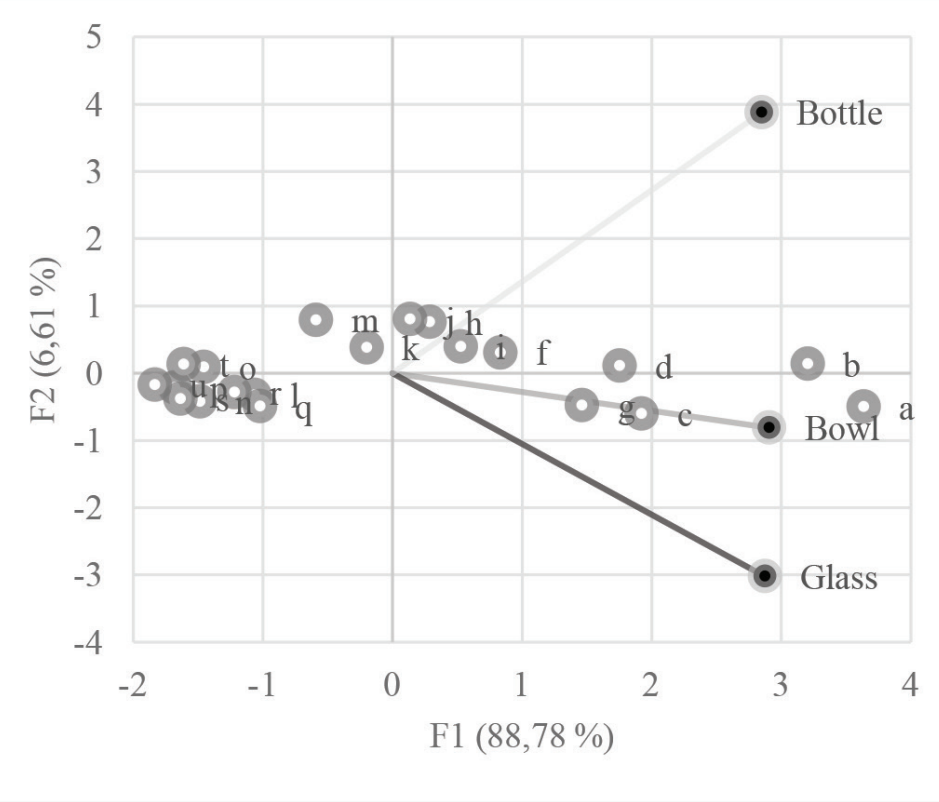




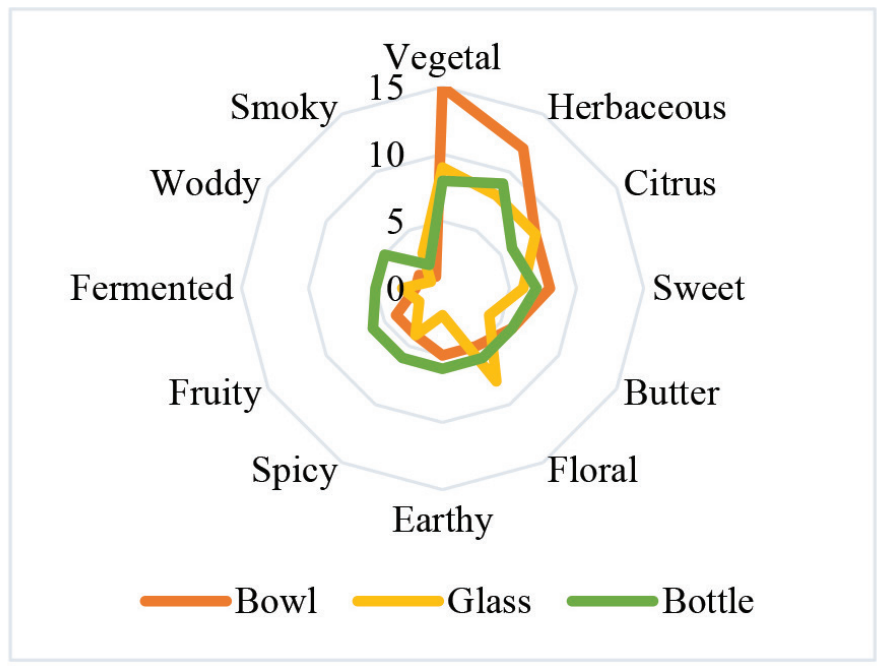

\author{
FIgURE 41. Profile \\ spider chart hem in \\ positives counting of \\ the relevant aromatic \\ characteristics for the \\ three containers.
}

About the structured numeric scale test, contrary to expectations, the impact of the presentation of a dish in containers with different designs and characteristics did not reach significance $(p \geq 0.05)$ in terms of participant's perceptions of the aromas added by green mandarin and ginger essential oils. This means that, in this study, their aromatic intensity did not depend on the containers used.

\title{
7.2.7. Discussion
}

The results show that tasters' olfactory perception changed significantly. In general, the best container to enhance the smell and aroma of the roasted celeriac cream was the glass in the sniffing and sipping tests. It is well known that the impact of glassware is important when tasting wine. There are some scientific researches [187], [188] about how the physical parameters of a glass: size, shape and opening influence wine tasting. A glassware with a more closed opening concentrates wine aromas around the rim so tasters pointing the nose towards the centre of the glass, distinguish aromas easier and experience all aromatic potential [189]. This can also justify our results.

When using a spoon, no significant difference in aroma perception was encountered. It can be assumed that the cutlery cuts the link between the container characteristics and human physiological perception, equalizing and limiting sensory perception. This can also be the explanation for the fact that away from the restaurant everyone prefers to eat roasted chicken by hands, and also that sushi is traditionally eaten by hands [190].

The smell perceived for the cream served in the bottle was the less intense, the organic shape appearance and the lid with holes did not prevent the food from being totally exposed to the exterior atmosphere, resulting in a faster cooling down of the cream during tasting. Lower temperatures reduce odour and flavour intensities [191]. Also less steam is available and so a smaller amount of airborne odorants are released and reach the cilia in order to stimulate olfactory cells [104], [124], [192]. 
Figure 42. Five thermal pictures in sequence using a Flir®, of the bottle dish within 3 minutes difference between each.

Figure 43. Five thermal pictures in sequence using a

Flir®, of the glass dish within 3 minutes difference between

each.

Figure 44. Five thermal pictures in sequence using a Flir®, of the bowl dish within 3 minutes difference between each.

Better resolution of pictures avaiable at $C D$.

FIgURE 45. Three thermal pictures in sequence using a $\mathrm{Flir} \circledast$, of the glass dish of ceramic by Vista Alegre within 10 minutes difference between each.

Figure 46. Three thermal pictures in sequence using a Flirß, of the bottle dish of ceramic by Vista Alegre within 10 minutes difference between each.
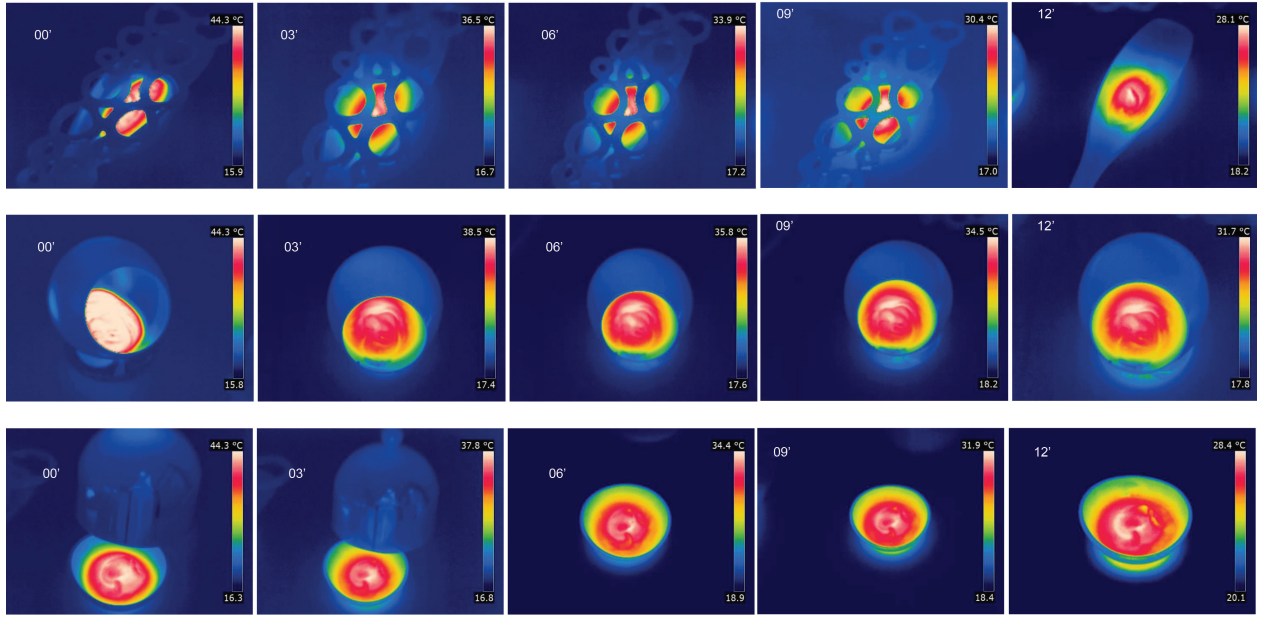

In order to confirm the hypothesis just referred, a Flir@ thermal T360 camera, provided by J.ROMA, LDA, was used to register the cooling process of the food in the three plates during 11 minutes after been plated (fig. 42, 43, 44 and 47). The process involves detecting and measuring infrared rays irradiated from an object, which allows measuring the object's temperature. The results are presented as a picture in which each pixel appears in a different colour related to the temperature. On the right side of each picture there is a scale with the range of temperatures between the maximum and the minimum limits. The camera has $<0.07^{\circ} \mathrm{C}$ thermal sensitivity.

As proved on the figures $42,43,44$ and 47 the 3 containers used on this study have different cooling rates. In the glass container the cooling rate is lower than in the bowl or bottle. The bottle container has a holy lid that does not retain any steam it also has the largest surface area of contact with the puree, causing the fastest cooling of the three. The bowl was the second fastest to cool down, after the cloche removal the cooling process become evident. The cloche was trapping the steam in its headspace, without it the purée is more exposed. The glass is the container which better preserves the aromas and the temperature, its upper part maintains eventual steam on head space and its walls isolates from exterior atmosphere.

The containers produced at Vista Alegre were also photographed by Flir ${ }^{\circledR}$ thermal T360. As the ceramic is thicker than the glass itself the temperatures took longer to decrease so the clicks were done within 10 minutes as illustrated bellow on figure 45,46 and 48 .
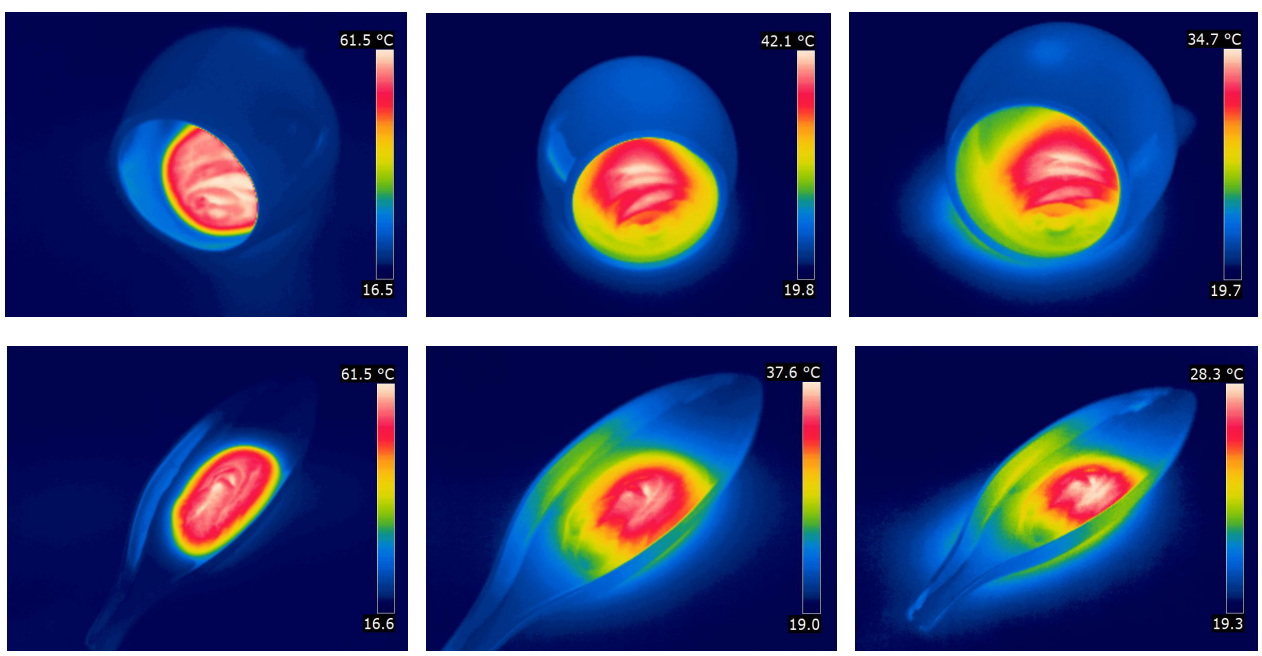

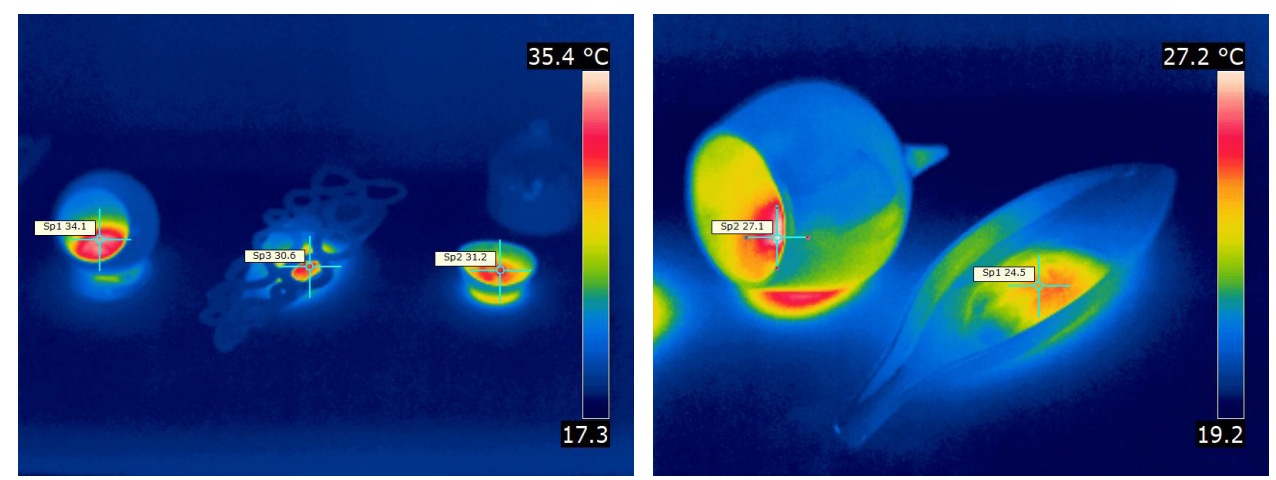

FIGURE 47. Single

thermal pictures using

a Flir $\circledast$, of the three

dishes: glass, bottle and bowl (from left to right reading), picture took after 11 minutes after being plated.

FIGURE 48. Single thermal pictures using

For the bowl, the smell intensity perceived by sniffing was similar to the glass, however the aroma intensity perceived by sipping was the less intense. This can be related to the cloche cover. For the sniffing test, the cover was removed for the first time and the volatiles were concentrated in the cloche headspace. For the sipping the cloche was kept away, the bowl was then without the headspace concentrated odorants. Spencer (2015) showed that this happened with coffee, once it is smelled for the first time after removing the lid the aroma intensity will never be that strong again.

a Flir®, of both dish-

es: glass and bottle

(from left to right reading), picture took after 30 minutes after being plated.

Shape symbolism can justify the results of the variance of aromatic characteristics obtained in the second test. The bottle, the container that has the most organic shape look, as the base seems a bamboo leaf and the lid looks like stones, is associated with earthy, spicy, fruity, fermented and woody aromas. A sensation transference might have occurred and the attributes of the container influenced the rated attributes of the food [142]. The bowl was evaluated as vegetal, herbaceous, citrus and sweet. The shape of the bowl and cloche are completely round, circle shapes enhance the sweet sensitivity [98], [115], [117], [144], [154]. The citrus features were associated equally to the bowl and the glass, it has been shown that various citrus components present in green mandarin essential oil (Organic Skin Food ${ }^{\circ}$ producer and seller stated containing $70,44 \%$ of limonene analysed by gas chromatography-mass spectrometry at $20^{\circ} \mathrm{C}$, by HP5890), can reduce the odour perception of others components [193].

The results of the last test were not significant, this can be explained by the fact that the sensory perception can change with repetitive tasting of the same food, and can either decrease, due to sensory specific satiety, boredom or irritation, or increase, due to increased familiarity and/or a change in perceived complexity, which in turn can impact on perception [194]. Most sensory perception research is based on single sips or single bites in order to avoid olfactory adaptation, and the tests should be discontinuous or with some resting periods to allow nerves recover from their refractory state [195].

Further research should be carried out in order to assess the validity of this experiment. Particularly reducing the amount of aromas, and designing a shorter sensory test. Also, future studies should involve a larger number of tasters in order to find more robust differences.

\subsubsection{Conclusion}

According to Spence (2014) making chefs and culinary artists aware of the power of smell will make them think about their food delivery and multisensory experience design.

Our findings suggest that different designs of containers, as well as the process used to eat, can modify the aroma and smell perception. The container with the glass shape was identified as the best for enhancing the olfactory perception of the dish.

This type of knowledge can be relevant in the development of new dishes and menus, as well to plateware producers. However, there is still room for further investigation regarding the characteristics of the perfect plate to enhance the aroma perception. Design promotes possibilities, approaches and 
competencies required for this kind of projects and, if needed, to allow results to be reformulated, sharpened, redefined and reframed [196].

There is an increasing need for multidisciplinary approaches to better understand the mechanisms involved in flavour perception.

FIGURE 49. Drinkable

Smoke, Ceramic

Glass container from

Vista Alegre, 2018

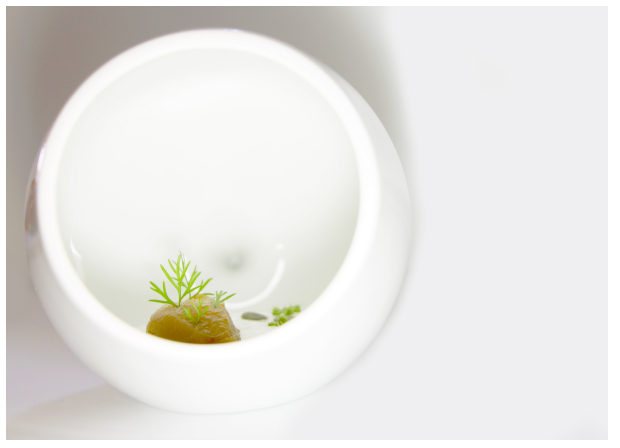

\subsection{HEARING}

\subsubsection{Objectives}

Consumer perception is inherently multisensory! As Spence affirms sound has been the forgotten sense and the sound of a product can indeed change its feel [118]. For Charles Spence, music functions as a flavouring that can contribute to the improvement or, just, alteration of the gastronomic perception [118].

The third moment in this menu, the main course, is presented as the sunrise and its focus is on the hearing sense. It is supposed to look like an authentic bush, with mushrooms, edible crunchy leaves, branches and the "wooden" sticks made with 100\% dark chocolate, flowers and truffles to impart the terroir flavour, and sauce drops to represent the morning dew.

On 2012, while the author was in a work placement at the three Michelin stared restaurant The Fat Duck, in Bray, near London, he became aware of the work of Chef Heston Blumenthal with Prof. Charles Spence whose aim was to use sound to enhance the impact of the dining experience. Specifically, research on the impact of environmental sounds on the perception of the flavour and hedonic quality of food and drink. In this context, it was demonstrated that people rate bacon-and-egg ice cream as tasting significantly more bacony when listening to the sound of sizzling bacon than to a farmyard full of clucking chickens [148]. It was also shown that oysters eaten while listening to the 'sound of the sea' (a soundtrack incorporating the sound of seagulls squawking and waves rhythmically crashing on the beach) were rated as tasting significantly more pleasant, saltier and fresher, than oysters eaten while listening to farmyard noises instead. Taken together, these results highlight just how dramatically environmental sounds can influence the perception of food. They also emphasize the importance of having an ambient sound not only pleasant, but also congruent with the product/experience that the consumer is hopefully enjoying [148.

However, it did not seem appropriate to have big headphones in the restaurant, and customers should not feel as participating in a scientific experiment, this is not the purpose of a restaurant experience. It took three years to $\mathrm{H}$. Blumenthal to come with the right idea for a dish, based on this knowledge, which was named Sound of the Sea and introduced in the tasting menu at The Fat Duck restaurant [6]. Diners are presented with a plate of food that is reminiscent of a beach, having components that look like sea foam, seaweed, and sand). With the dish arrives a mini iPod hidden inside a sea-shell, with the earphones sticking out. Diners are encouraged to insert the headphones before starting to eat. It is an original experience, and dinners appear to enjoy the dish [6]. In fact, since 2007 the Sound of the Sea (see figure 51 and 52) is included on the tasting menu of The Fat Duck being currently one of the signature dishes of $\mathrm{H}$. Blumenthal [156]. 
Sound can have an important impact in the perception of food and must be considered when creating a dish.

\section{"SOUND IS ONE OF THE INGREDIENTS THAT THE CHEF HAS AT HIS/ HER DISPOSAL"[156].}
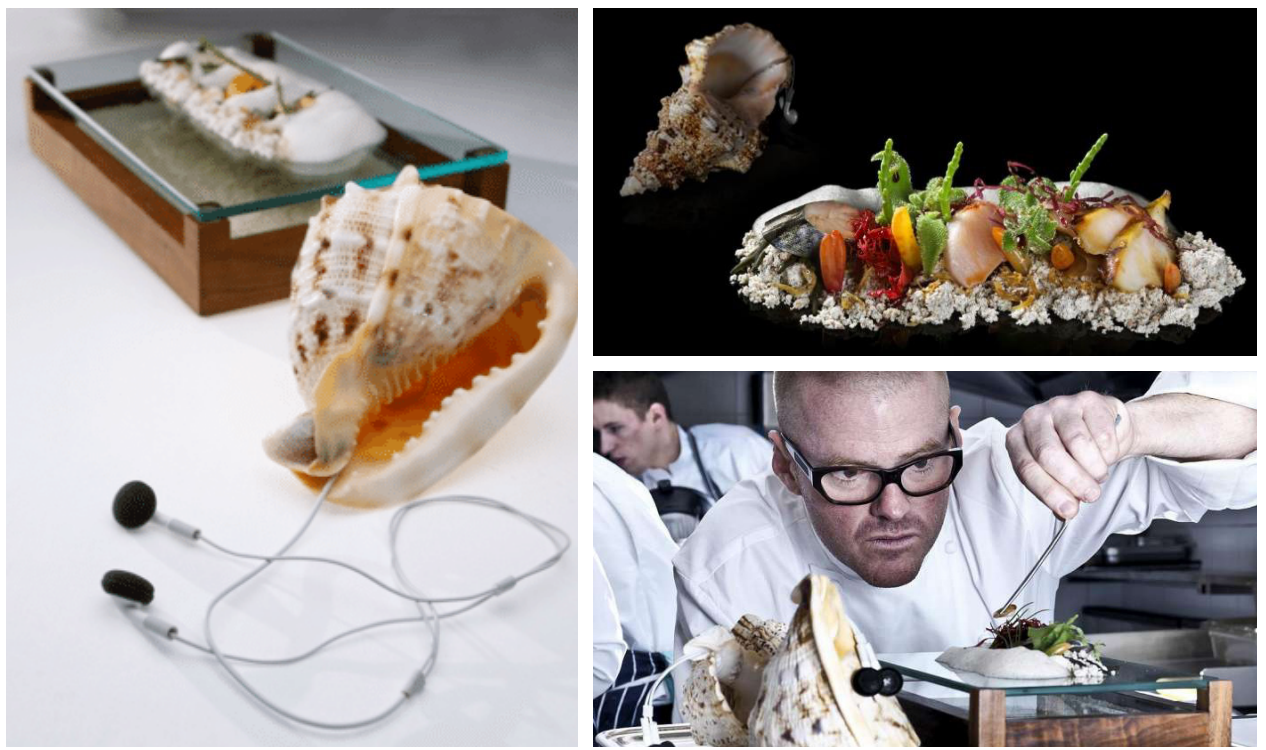

FIGURE 50. Sound of the Sea Dish, Heston Blumenthal, 2008

FIGURE 51. Sound of the Sea Dish, Heston Blumenthal, 2008

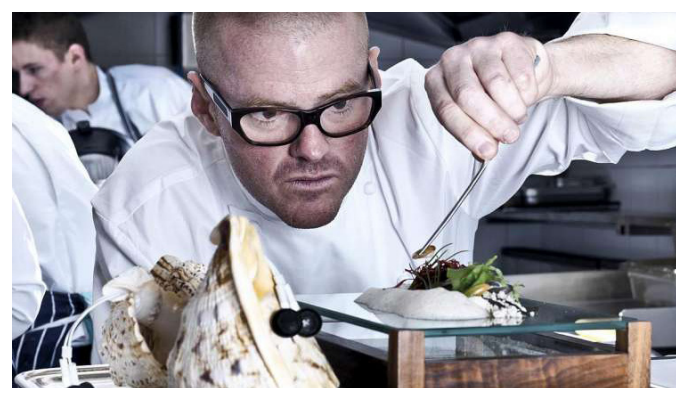

FIGURE 52. Heston Blumenthal plating Sound of the Sea Dish, 2008

\subsubsection{Dish composition}

The dish here presented, called as the Sound of the Forest, was inspired by $\mathrm{H}$. Blumenthal's Sounds of the Sea. It consists on an interpretation and representation of nature, particularly a forest, using elements which remind it due to its origin, flavour and visual characteristics. This link is enhanced through auditory cues in order to create a more intense and pleasant experience. Rabbit loin, black truffles, cocoa, active charcoal, carrots, turnips and onions are some of the ingredients that compose the eleven elements of the dish "sounds of the forest" illustrated below. The aim was to achieve unity in the dish, globally representing a forest, but allowing each element to express its own identity and characteristics. (see 10.3. For full recipe).

1| Rabbit loin rolled in chard leaves - Sous vide slow cooked rabbit loin, previous rolled in steamed bio chard leaves. Keeps the juices and flavours of these two ingredients associated with the tenderness of the meat. Rabbit was chosen as it is a low profile meat, light in fat.

2 | Edible Soil - Maltodextrin with walnuts oil, truffle chopped in brunoise, cocoa powder, paprika, activated coal and fried buckwheat. The oil with maltodextrin gives the sand texture by adsorption of the fat to the maltodextrin particles. The truffle and the fried buckwheat provide some crunchiness to the soil. Cacao, paprika and activated coal, all in powder, create a good combination of realistic colourants for final result.

3 | Fried Bio Cabbage - Cabbage firstly blanched, then drained, dried and deep fried. Increases crunchiness on the dish, due auditory cues.

4| Burnt Onion - Organic onions cut in half and grilled on a very hot frying pan, until totally black on the bottom. This cooking method increases the bitter taste and also, due to caramelization of the onion sugar, a more complex flavour is achieved. 
5| Baby Carrot, Baby Turnip, Scallions And Shimeji Mushrooms - The first three, freshly picked and provided by Microgreens ${ }^{\circledR}$, were washed, peeled and blanched to maintain hardness. Shimeji mushrooms were plated raw to increase the diversity of the tactile experience. Vegetables here offer crunchiness, auditory cues, vegetal flavour and colours.

6 | Pea Protein Mayonnaise With Vanilla Seeds - Egg-free mayonnaise in which pea protein was used to emulsify. This imparts a distinct cereal and botanical flavour to this element.

7 | Pea Sprouts - Freshly picked and provided by Microgreens $®$, were only washed and plated. Apart from the interesting visual of spirals, this sprout tastes as dry cereals.

8 | Dew Drops - To impersonate the morning dew of the forest, a sugar and salt syrup was made, the sugar gives density to the drops and salt intensifies the flavour of the whole dish.

9 | Chocolate Hard and Crispy Branches - 80\% dark chocolate was tempered and then breaded with cocoa powder.

10 | Infused Veil - To represent a river a thin gel structure was made with carob gum and carrageenan with soil flavour. Previously, oak tree soil was infused in water by ultrasonic vibration then, using the rotavap, a clarified liquid full of terroir flavour was obtained. dish.

11 | Tagete Petals - Contribute to colour contrast and provide a dry and sour vegetal flavour to the

As the dish is focused in the hearing sense, it is paired with an audio component: an iPod hidden inside a tree branch placed aside the dish that will reproduce some forest sounds, water stream, birds chirping, wind, breeze and branches breaking. This melody will focus consumer concentration in all the details in the dish and increase its complexity, perception and pleasantness.

FIGURE 53. Sounds of

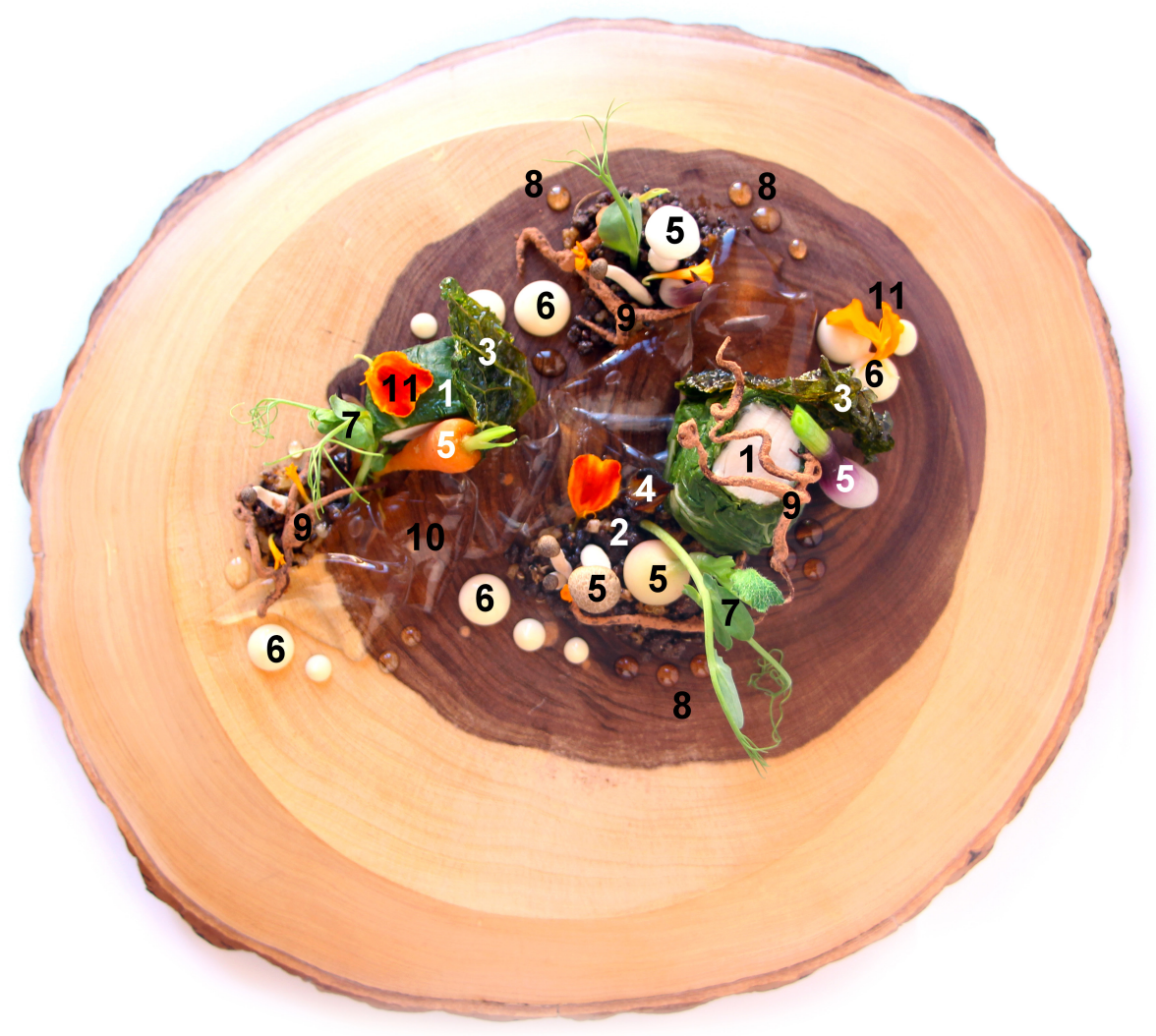




\subsubsection{Techniques applied}

Auditory cues come from the music and from the physical caracteristics of the food elements in the dish. The culinary techiques and preparation define and modulate these caracteristics.

1 | Rabbit loin was cooked by sous vide technique. In this technique, vacuum packed food, in appropriate plastic bags, is submitted to long cooking process, in a precision thermostatic bath, at constant low temperature. Each ingredient having its optimal temperature of cooking which depends on its physical or chemical characteristics. This process prevents oxidation and loss of volatile compounds and humidity, allowing to optimize flavour and preserving nutrients. It also allows a good control of the extension of protein denaturation, and consequently products of excellence with improved textures are obtained [86]. Prolonged cooking can double the meat's softness by dissolving all collagen in gelatin and reducing inter-fiber adhesion until it collapses [7].

A thermometer with a needle should be used to determine when the food has reached the desired temperature. To prevent air or water from entering the pouch, the thermometer should be inserted through a closed cell foam tape. The aimed interior temperature of the rabbit loin was $63^{\circ} \mathrm{C}$.

It is a delicate and slow method, involving an efficient transfer of thermal energy from water to food, and respecting the integrity of the food as well as its nutrients and optimizing results [86].

3, 5 | Cabbage, baby carrot, baby turnip, scallions, were blanched. Boiling in water softens plant tissues as when its temperature reaches $60^{\circ} \mathrm{C}$, the cell membranes are damaged, the cells lose water and deflate, and the tissues as a whole go from firm and crisp to limp and flabby. Blanching, consists in a process in which food is immersed in boiling water for a minute or two, just enough time to inactivate the enzymes to prevent oxidation and discolouration, and then is rapidly immersed in cold water to stop further cooking and softening of the cell walls [135]. This method allows to get the desired crispiness of the baby carrots, turnip and cabbage.

2 | Edible Soil - Maltodextrins are non-sweet, nutritive saccharide polymers consisting of D-glucosyl units linked primarily with alpha-1,4 bonds [197]. Typical starch sources are corn, potato, tapioca, and rice. Maltodextrins are highly digestible (supplying $4 \mathrm{kcal} / \mathrm{g}$ ), are easy to blend with other dry ingredients, are readily dissolved, and have low viscosity in solution. The main function of the soft and spreadable maltodextrin gels is to provide texture and mouthfeel simulation of fats in food products. Maltodextrins may also act as bulking agents [198]. Maltodextrin adsorption of oils allows to obtain what is known in molecular cuisine by powdered oils.

6 | Pea protein mayonnaise- Emulsions are the basis of a huge range of food products and are generally stabilised by either protein and/or surfactants. Proteins stabilise emulsions by forming viscoelastic adsorbed layers, and their mechanical properties influence the emulsions stability. Oil-in-water emulsions, such as mayonnaises and salad dressings, were traditionally stabilised by egg yolk lipoproteins. These proteins can be fully replaced by vegetable protein isolates. The main advantages of this substitution results from the growing interest on low-cholesterol and animal-free food emulsions, low fat and easier to handle with an expected positive agricultural impact [199] a natural ingredi-ent, to colour oil-in-water pea protein stabilised emulsions was studied. Various levels of incorporation of Chlorella vulgaris green, Chlorella vulgaris orange (after caroteno- genesis. Besides its nutritional characteristics, leguminous seeds such as lupin (Lupinus albus) or pea (Pisum sativum L.) protein isolates present good functional properties, namely emulsion and gelling capacity [200].

According to Gouveia et al. 2006a natural ingredient, to colour oil-in-water pea protein stabilised emulsions was studied. Various levels of incorporation of Chlorella vulgaris green, Chlorella vulgaris orange (after caroteno- genesis procedure, oil/water emulsions (mayonnaise like) with $3 \%(\mathrm{w} / \mathrm{w})$ pea protein isolate (Pisane HD, Cosura, Belgium) and containing $65 \%(\mathrm{w} / \mathrm{w})$ commercial oil were prepared with vanilla seeds. Protein isolate and vanilla seeds were dispersed in water, under magnetic stirring (30min) at room temperature. Emulsification was carried out using a hand blender at constant mechanical energy (3 min). 
9 | Tempered Chocolate - Cocoa butter can crystallize into six polymorphic forms different stability and physical characteristics such as gloss, hardness, and melting point. The chemical composition is identical in all forms; only the arrangement of the lipid molecules varies.

Figure 54. Tempering sequence during lipid crystallisation in chocolates, Afoakwa, 2010

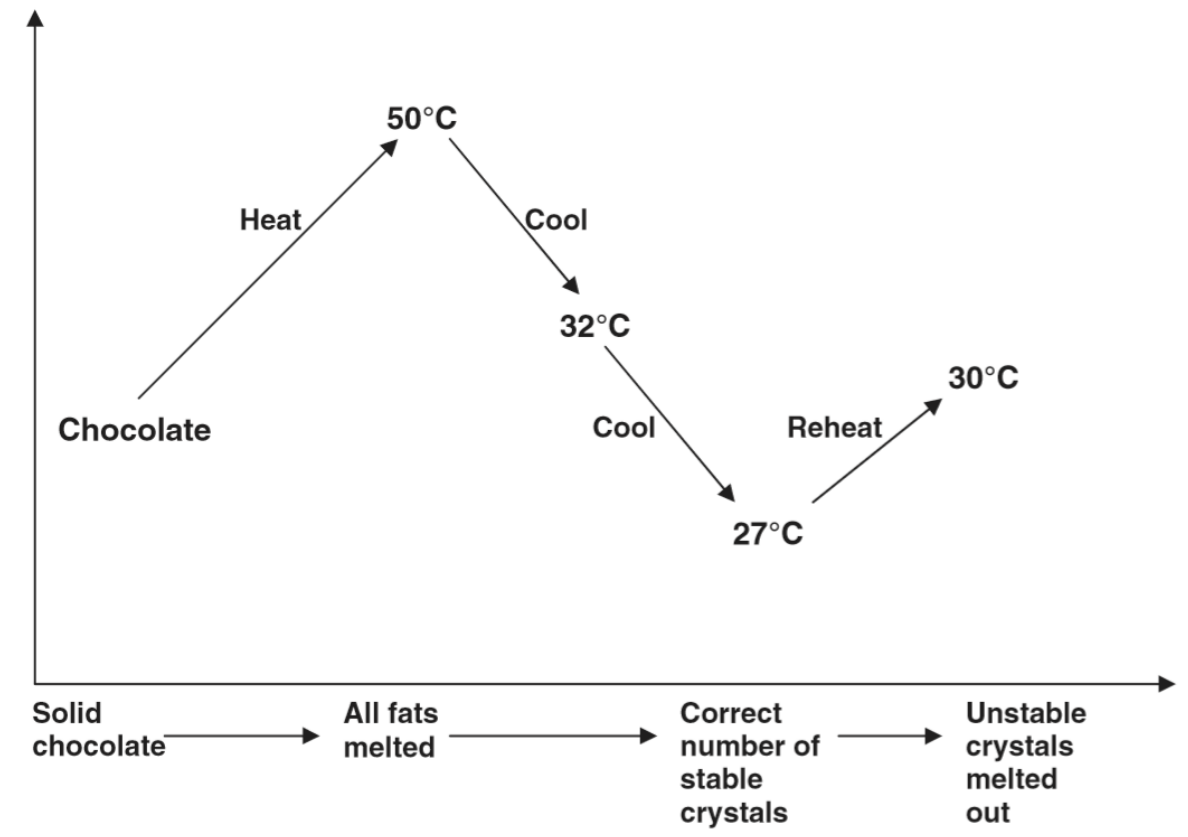

Tempering chocolate involves pre-crystallisation of a small proportion of triglycerides, with crystals forming nuclei (1-3\% total) for remaining lipid to set in the correct form. Tempering has four key steps (see figure 54): melting to completion (at $50{ }^{\circ} \mathrm{C}$ ), cooling to point of crystallisation (at $32{ }^{\circ} \mathrm{C}$ ), crystallisation $($ at $27 \circ \mathrm{C}$ ) and conversion of any unstable crystals (at 29-31.C $)$ [201].

A well-tempered chocolate will have the following properties: good shape, colour, gloss, contraction from the mould, better weight control, stable product - harder and more heat resistant and longer shelflife [201].

10 | Infused Veil, a thin gel structure was made with Elastic by Sosa $\AA$, the technique was previously described (see chapter 7.5.3.). The soil flavour was obtained by oak tree soil infusion in water applying ultrasonic vibration, then distillation in a rotavap was performed to obtain a limpid flavoured liquid.

Ultrasound-assisted extraction (UAE) is a green and economically viable alternative to conventional techniques for food and natural products. The combinations of the different mechanisms involved during UAE (fragmentation, erosion, sonocapillarity effect, local shear stress, detexturation of plant structures, and sonoporation) allow to increase mass transfer of the intracellular material, and decrease the extraction and processing time, the amount of energy and solvents used, unit operations, and $\mathrm{CO}_{2}$ emissions. The UAE of active compounds, flavours and spices from plant material is a very successful application, as a more efficient extraction and higher yields are obtained [202].

Chef Sang Hoon Degeimbre at L'Air du Temps Restaurant uses ultrasound technique, justifying it by saying that he does not want to cook, but he wants to have the most fragrant part of the plant material [159].

For the Soil Infused veil river in this dish an Ultrasound SONICS VCX500 was used in one single cycle at $100 \mathrm{~Hz}$ for 15 minutes. After that Rotavap Buchi R-300 was used for a low pressure evaporation of the previous mixture. The temperature of the water bath at $55^{\circ} \mathrm{C}$, with refrigerator was at $-10^{\circ} \mathrm{C}$, the pressure $35 \mathrm{mbar}$ and rotation was at $100 \mathrm{rpm}$. 


\subsubsection{Plate Design}

This dish was developed in 4 phases, applying the Double Diamond design process [1]:

$1^{\text {st }}$ Phase - Discover of how to use and create the auditory cues in the dish, search for cooking techniques, investigate similar works.

$2^{\text {nd }}$ Phase - Define the brainstorming results and select what really matters to the hearing sense.

$3^{\text {rd }}$ Phase - Develop prototypes, test elements and recipes. Check drafts on figure 57.

$4^{\text {th }}$ Phase - Deliver the final version of the dish.

The plate itself is a 3 centimetres high layer cut from a tree trunk, after that was polished, and varnished. The bark of the tree was maintained to preserve the natural and organic appearance.

Another structure, presented simultaneously, is a tree branch with an iPod hidden inside that reproduces forest sounds, water stream, birds chirping, wind, breeze and branches breaking. This piece also works as base for cutlery for this dish.

All the visual information is obvious, with organic, vegetal and wooden appearance. It creates a direct connection between the consumer and a forest environment. The sound component will further define, complement and enhance the sensory experience.

Concerning to the food plating, the colours are entirely organic, tones of brown, green, orange and yellow. Natural forms, lines and dots create a forest representation. The visual texture of the elements, its scale, dimensions and movements conferred by irregularity and randomness result in a harmonic vegetal composition.

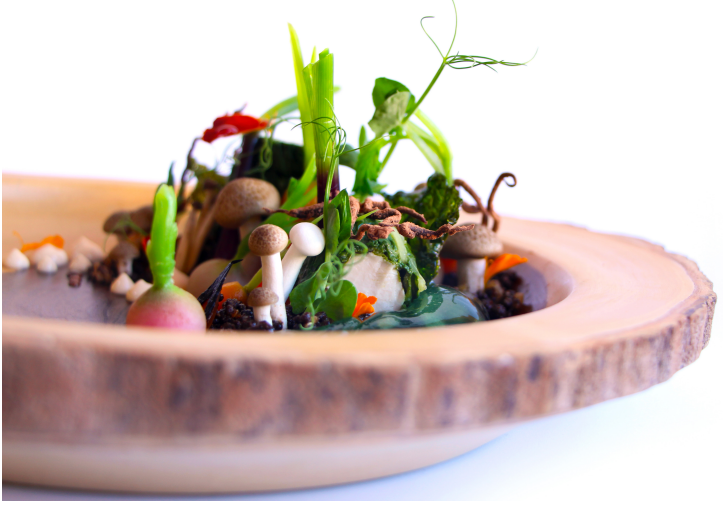

FIGURE 55. Sounds of the Forest, 2018

\subsubsection{Results and discussion}

Considering the study by LEONOR (2014) of the Sounds of the Sea dish, it is believed that for Sounds of the Forest the results are likely associated. Nostalgia triggered by sound is going to affect the flavour perception of Sound of the Forest. The sounds of the nature should enhance the earthy and green notes of the dish, in the same way sea sounds evoking seaside memories and taste related to it made the Sound of the Sea taste fresher and saltier [148]. Sensory analysis would be needed to evaluate if this happens and to find which basic taste increases the most, since the cross modal correspondence differ from person to person and from sea to forest. Sound may create context and affects enjoyment of the dish [148]. Also when nostalgia is triggered by a pleasant memory, the dish is better evaluated overall, thus people will have different eating experiences [158]. In fact, the orbitofrontal cortex is closely related to memory and emotion, and the eating experience depends on the mapping of the flavour molecules together with the inputs from other senses [157]. 

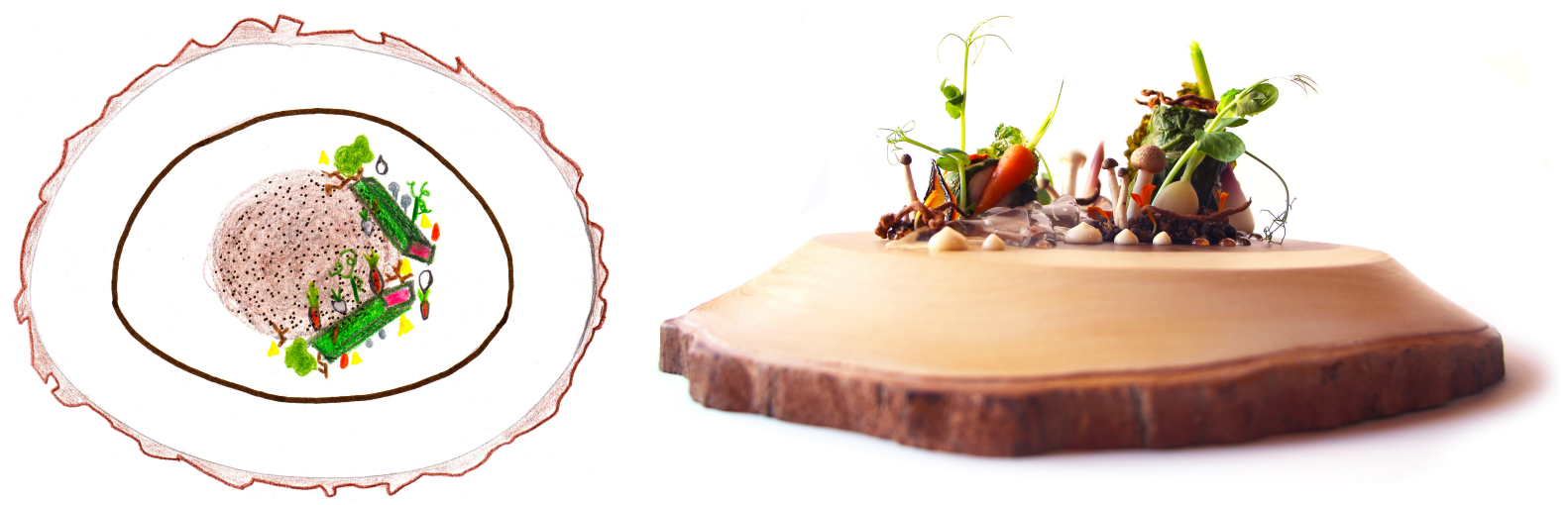

FIGURE 56. Sounds of

the Forest, 2018

FIGURE 57. Sounds of

the Forest draft, 2018

Considering the above, it is expected that sound would make participants evaluate higher the overall deliciousness of the dish, but once again, this can only be confirmed by sensory analysis.

There are some others auditory issues that interfere with our perception of food, for instance, the Lombard effect [203], which occurs when a restaurant is full and people tend to speak louder, in order to override the noise of others and, on the contrary, contribute snowballing to the increase in total noise. This can influence food perception, for example Seo et al (2013) stated that noise reduces odour perception. With Sounds of the Sea/ Forest, using earphones will reduce this effect.

Wearing the headphones also has the advantage of making the diner's attention to focus on the food itself, and this too helps to enhance the flavour of the food.

Also, the name Sounds of the Forest by itself creates interaction with the taster auditory cues, increasing expectations and awakening the hearing sense. Since the late 1990s' when Heston Blumenthal discovered that costumers actually perceived crab ice cream differently depending on what it was called, he got fascinated about the way flavour is perceived and how subjective it is (BLumENTHAL, 2008). The impact of the name can help to improve brand assignment by taking into account the type of product ( SPEnCE \& GALLACE, 2011). Studies, in the field of psychology and neuroscience, suggest that a food can be perceived as being sweet just because it has been given the name rose [149].

Research has demonstrated that our abilities to detect low concentrations of both smell and taste stimuli are significantly impeded by stress. The longer or more severe the stress, the more impaired our abilities to smell and taste [204]. Excessive stress makes the chemical senses become less sensitive, and the ability to properly assess the foods can become compromised [205]. Music calms people down, and the music chosen was developed (track available at https://bit.ly/2Ck4Frv) with this aim, this can be another reason to expect that it contributes to enhance the eating experience. 


\subsubsection{Conclusion}

Sound design in the world of fine dining has now come so far that it is not unheard of to find musical composers working alongside chefs in some of the world's top restaurants (see, for example, Restaurant Denis Martin). The composers try to create the music and soundscapes that will optimally complement the various courses in the meal. Until recently, intuition was all they used when thinking about which particular sounds / instruments to best complement a given dish [148], [150].

Research as the one by Charles Spence and Heston Blumenthal allows to better understand the influence of the sound and the memories associated with it in food perception. The work here described is based on, and inspired by their work. However, no evaluation was made of the effect of the music due to the extension of the work developed and the time available [150] However, it should interesting, and important, to evaluate the effect of sound in the perception of the Sound of Forest dish.

Research of other authors suggest that even a single and specific memory, the same for everyone, allows each individual to perceive it differently, due to his own interpretation of the memory triggered [210]. Theoretically this allows the experience to be cross cultural and not to be affected by language. Although it permits reaching a wider number of people, this may be limiting because each individual has his own forest memories already mapped in his brain [148], [150], [158]. Prescott (2008) defends that this type of phenomenon happens due to our natural ability for associative learning of food. Each individual is able to evoke emotional memories by an eating experience.

It is important to bear in mind the congruency between the restaurant concept, the clientele, and the type of music that is played [150], [153].

"You sell the sizzle not the steak." [151]. Sonic seasoning has been a forgotten flavour sense that can significantly influence our perception. Sounds of the forest contextualizes the scenario and season the flavours. 


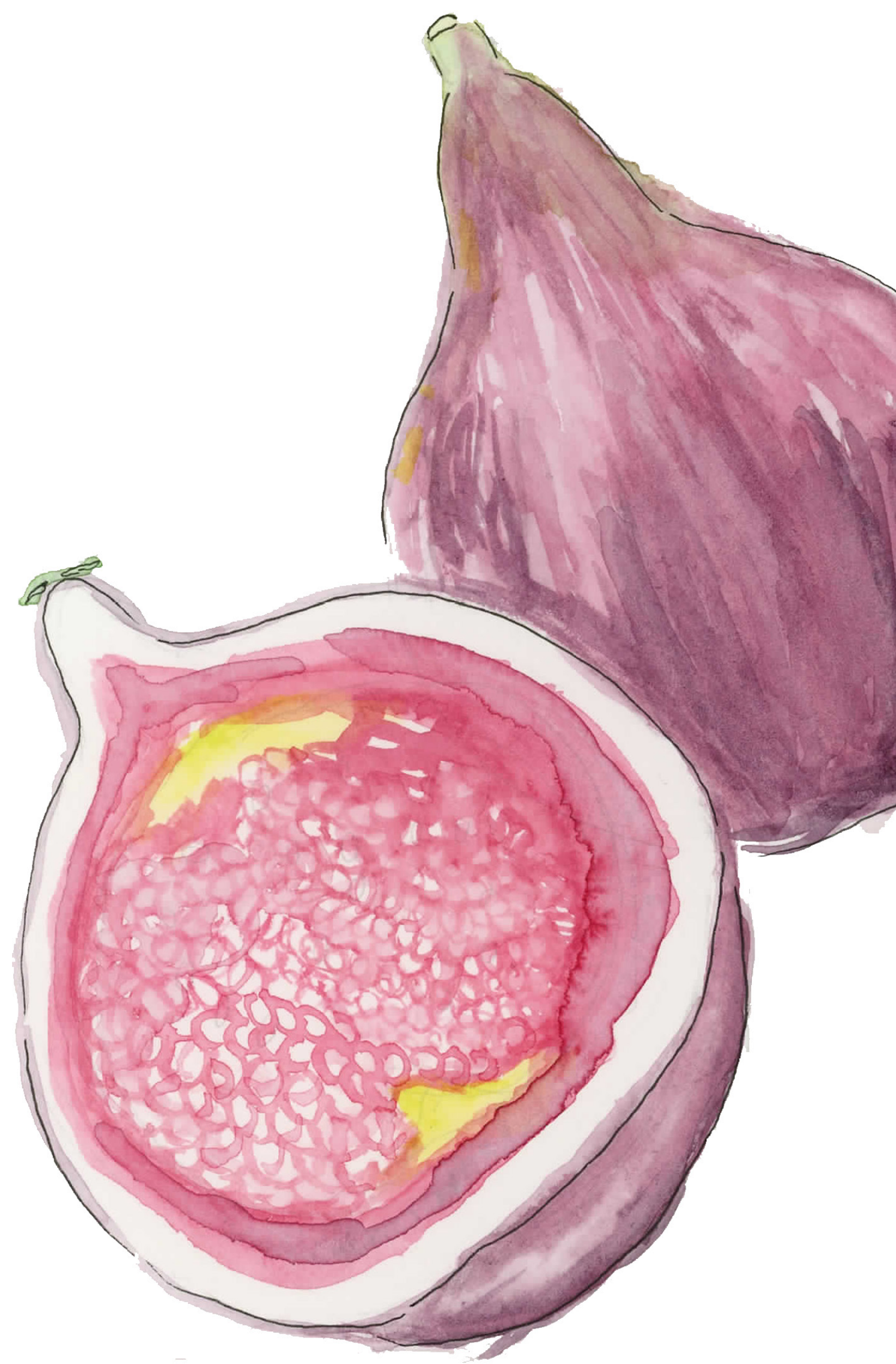

ILLUSTRATION | Sandra Nguyen 


\subsection{TASTE}

\subsubsection{Objectives}

The forth moment of the menu is directed to the taste sense and, as a pre-dessert, will be a small dish to clean the palate, working also as an introduction for the next dessert dish. Senses, specially the taste, easily get saturated, so it is important to awaken them again by re-establishing the mouth condition. This can be done with an efficient palate cleaner (PC) [207].

It is the mouth that contributes to the final and important decision of swallowing food [121]. Flavour encompasses taste, aromatics from olfactory perceptions and trigeminal sensations. Taste is only focused in the five basic tastes although it is sometimes difficult to isolate them when analysing food perception. Taste results from a set of small non-volatile molecular compounds, which are in most cases water soluble. It is associated with the perception of sweet, sour, salty, bitter and umami in foods. The chemical signal triggered by the stimulus is converted to an electric impulse that is sent via afferent nerve to the nucleus of the solitary tract and ultimately to cortical regions of the brain. There are thousands of chemically distinct non-volatile compounds that elicit taste. Although salt taste is elicited by many ionic tastants, sodium ions are the most relevant and the mechanism for salt detection involves the amiloride-sensitive epithelial sodium channel ENAC. Sour taste is due to the titratable acidity of the stimulus rather than only its $\mathrm{pH}$. In fact, organic acids, including citric acid, tartaric acid, lactic acid and acetic acid, can also stimulate a sour taste response [155]. Sweet taste perception due to sucrose or artificial sweeteners, is initiated by the interaction of a sweetener with $G$ protein-coupled taste receptors in the apical part of Taste Receptor Cells. Umami is the taste generated mainly by monosodium L-glutamate [208] which is known to bind $G$ protein-coupled receptors and activates second messengers [121]. Flavour may also be influenced by tactile, thermal, painful and/or kinaesthetic effects [209].

One of the biggest barriers when tasting is adaptation of taste, this happens often almost completely within a minute or so of continuous stimulation [124]. To avoid this Palate Cleansers (PC) are used. They are neutral-flavoured foods or drinks that minimizes residual substances in the oral environment that would otherwise interfere with the evaluation of a product. Theoretically, PC re-establish a baseline oral environment [210]. The use of PC is common practice in both informal and formal sensory evaluation settings. For example, fine dining restaurants may serve a lemon sorbet between courses in a meal, and slices of rare roast beef may be offered to counteract the effects of high-tannin red wines at wine tasting-events. More formal sensory evaluation studies use water or commercially available food products as palate cleansers. Water, sparkling water, crackers [210], pectin solution, cucumber, sorbet, carrots, chocolate, yogurt, milk, warm water, time, gums, mozzarella cheese, apple slices, rice, butter, and pineapple juice are some of the common PCs [211]. In French restaurants PC are also called as entrements or remise en bouche. The most famous and the one most adapted worldwide PC in restaurants are high-acidic sorbets, including sweet lemon and lime sorbet, as well as savoury tomato sorbet, which are considered to help cleanse rich, fatty flavours like light melon sorbet [207], [209]. Every time a PC is developed or added to a menu, information about the characteristics from previous courses and beverage should be taken in account to obtain an effective PC.

Charles Spence, has referred to mental PC, considering that its key effect can be a change on mental focus. In fact it can be considered that a palate cleanser refreshes the mind, not the mouth, and the mind can be refreshed without a palate cleanser [210]. Some experiments using mental PC have been studied 
as for example Spence investigated the impact of a plastic cow placed at the table of The Fat Duck as simple salt shaker or pepper grinder. This object invokes relaxation and humor and can work as a PC.

Greenly Fresh is a pre-dessert coherent with the wood's scene, which works as a PC. The objective is neutralizing and refreshing the palate to receive the upcoming dessert. The sorbet presented in this dish as a PC has a clean, bright flavour that leaves little or no aftertaste.

\subsubsection{Dish Composition}

Composed by 4 elements it consists on a lime and mint granita with apple strips impregnated with green tea, plated inside a coconut shell, sprinkled with green tea powder and a mint sprout Garnish (see 10.4. For full recipe).

Made out from simple ingredients this dish will provide two of the best things that work as PC, time and water [211], [212].

1| Lime and Mint Granita - Composed by approximately $85 \%$ of water, on the slow freezing process a great amount of ice crystals is formed and gives structure to this element. Water has no taste and dissolves water soluble compounds, working perfectly as a PC, especially when combined with acidity that causes salivation. Mint provides a fresh cooling effect. It is served at $-6^{\circ} \mathrm{C}$ the ideal temperature for ice creams at restaurants.

2 | Apple Strips - Granny smith apples are one of the most used ingredients as PC for sensory analysis purposes. Thinly sliced apple impregnated with green tea that confers some bitterness will work as a complementary PC, enhancing the power of palate cleaning. The apple is also carbonated with $\mathrm{CO}_{2}$, providing an extra trigeminal sensation.

3 | Mint Flowers - Confer in colour contrast and provide a dry and acid vegetal flavour to the dish.

4 | Green Tea Powder - Matcha powder was dusted on top of the apple strips to provide chromatic contrast and a touch of bitterness.

A limited number of elements compose this small dish, keeping it simple, but conferring acidity and a slight bitterness, the desirable characteristics to act as a PC. They also represent the green freshness and acidity of nature.

The wooden coconut shell as well as the bamboo spoon intend to fit the green and natural look of the dish. This plateware with organic lines embrace a dish full of freshness, citrus and mint flavour.

\subsubsection{Techniques Applied}

Several cooking techniques, and the scientific knowledge previously referred, were used to design and develop this dish (see figure 58), as described below. 


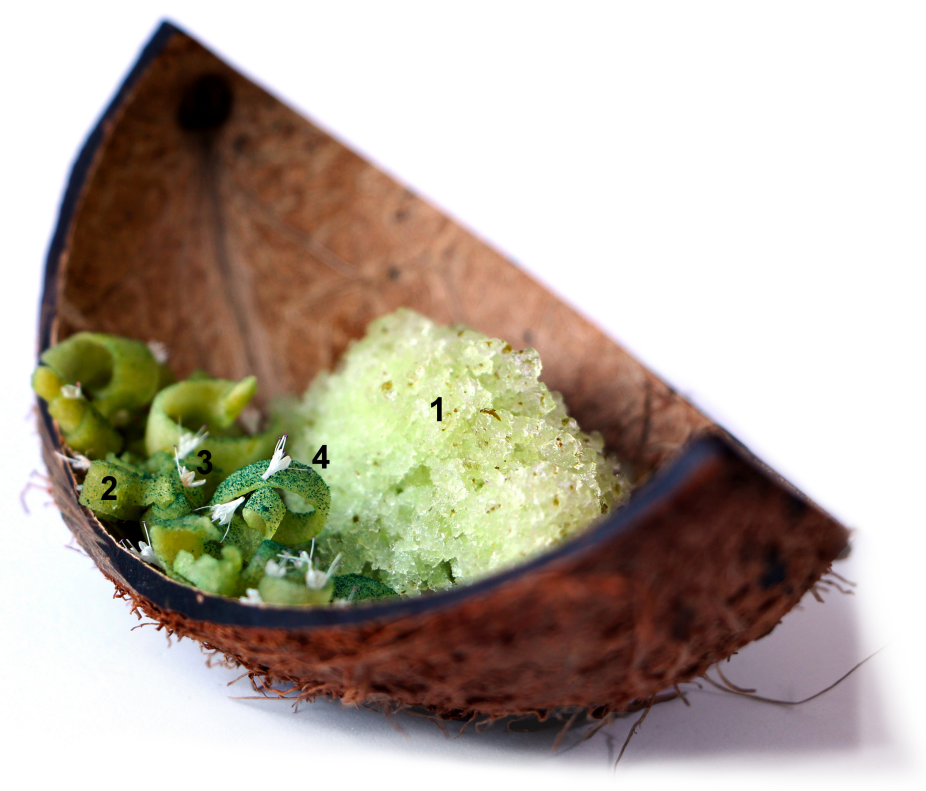

FIGURE 58. Greenly Fresh dish, numbering elements, 2018

1 | Lime and Mint Granita - This is a type of sorbet, with a coarse and rough texture. Ice crystals and the amount of water in it are the responsible for this consistency.

Granita starts with the same base as sorbet, the different characteristics between them are mainly the result of the different techniques used. The sorbet is churned in an ice cream maker, while for the granita the base is just poured into a pan and placed in the freezer. The iced surface is then scraped multiple times as it freezes, creating icy flakes.

As the temperature is reduced below $0{ }^{\circ} \mathrm{C}$ the water begins to be converted into ice. As a result, the dissolved solutes become increasingly concentrated in the remaining liquid water, further lowering its freezing point [7], [86], [213].

Two ingredients were added to increase the PC effect, malic acid (E296) which increases acidity and confers a pleasant sour taste and xanthan gum (See chapter 7.5.3) which increases viscosity and thus the time of contact with the oral cavity, making the cleaning more efficient [211].

Quinine is added to some drinks (e.g. tonic drinks contain approximately $80 \mathrm{mg} / \mathrm{L}$ ) and is used as a bitter reference compound for sensory evaluations. The limonin is another bitter component present for example in the lemon juice at $12,2 \mathrm{mg} / \mathrm{L}$. A simple way to reduce or mask bitterness is to add sweetness. Another strategy for bitterness reduction is based on bitter taste inhibition using, for example, zinc salt (E650), which suppresses the bitter taste of molecules such as quinine or denatonium benzoate. Other strategy used by food industry is to add sodium chloride to food. Is has been shown that salt enhances flavour by selectively inhibiting bitterness [104].

2 | Apple Strips - These were exposed initially to vacuum impregnation, and afterwards to carbonation.

Vacuum impregnation occurs in two successive stages. In the first, the food is introduced into a plastic bag together with the immersion liquid, and a negative pressure is applied. This causes the internal pore pressure to be greater than the external pressure, forcing the internal gases to expand and increase the volume [214]. In addition, native liquids and gases flow partially outward due to the pressure gradient. At this point the hydrodynamic mechanism begins and the outer liquid flows partially into the food, also as a consequence of the pressure gradient.

In the second step, the atmospheric pressure of the system is restored and the vacuum bag is hermetically sealed, the food being immersed in the solution during relaxation [214]. During this period, 
the pressure gradient generated (internal pore pressure < external pressure) promotes both the hydrodynamic mechanism and the deformation of the solid matrix (compression), which respectively produce impregnation and reduction of pore volume until a new balance is achieved.

The porous fraction of the plant tissue is the most important parameter for the application of the technique because it represents the empty space potentially available for the flow of the external solution thus, the greater the porosity of the product, the greater the effectiveness of the impregnation [214].

This process is performed with a vacuum chamber - a large, heavy and expensive equipment, used in kitchens for sous-vide cooking, impregnations, extractions or as an improvement in the quality and storage of food. To use the vacuum chamber, it is essential to use bags designed specifically for this purpose. The food is placed inside the bag and it is placed in the chamber with the open end in the sealing bar. After the cover is closed, a powerful vacuum pump evacuates the air. The sealing bar heats up, melting a strip of the bag and closing it. The chamber then returns to atmospheric pressure and unlocks the cap [86].

This technique is simple to use, but it is important to take into account that it should be applied to food at low temperatures and to set the proper pressure to the desired effect. After removing about $95 \%$ of the air from the bag, the boiling point of the water drops to about $30^{\circ} \mathrm{C}$ and continues to fall. If the food in the bag is at a higher temperature, it will boil, and the bag may collapse. In foods at refrigeration temperatures, water begins to evaporate rapidly at pressures below $20 \mathrm{mbar}$, and boils at 5-10 mbar. A pressure of 30-50 mbar fits almost all food without collapsing [86].

Vacuum impregnation has been studied as a method for enriching foods with functional compounds, to introduce ingredients with the aim of improving sensory properties, as well as for the introduction of compounds capable of inhibiting degradation or microbial growth reactions [214].

Acidity is another characteristic enhanced in the impregnated apple strips in order to prevent from oxidation and to provide a better final flavour. Acid (or Sour) is caused by hydrogen ions, $\mathrm{H}+$. Sourness comes from the weak citric acid solution of the lemon juice or the acetic acid in vinegar or even from the lactic acid developed by bacteria in yogurt. Different types of acids may improve some types of flavour compounds of food. For instance, malic acid not only promotes saliva appearing in the mouth - helping with mouthfeel and the brain thinking that what we are having is really good - but also enhances some fruit such as green apple flavour, the same happens with citric acid and citrus fruit [135], [136].

Carbonate fruit is one more culinary technique applied to this PC. The most common type of consumable carbonation is the fizzy soda. The bubbles in such a beverage come from carbon dioxide, which dissolves into the liquid under pressure during bottling and remerges in gaseous form to produce the characteristic fizz when the can is opened and the pressure relieved. A similar process can add a temporary but lively boost to fruits. If fruit is inserted in a pressure chamber with carbon dioxide, the gas will permeate the tissues and dissolve into the juice inside (see chapter 7.5.3 where siphon application is exposed). Neurobiologist Galen Kaufman patented a process for doing this in 1997, and he started a company, Fizzy Fruit [86].

FIGURE 59. Pates making, cutting with

hand saw, 2018

FIGURE 60. Plates drafts and trials, 2018
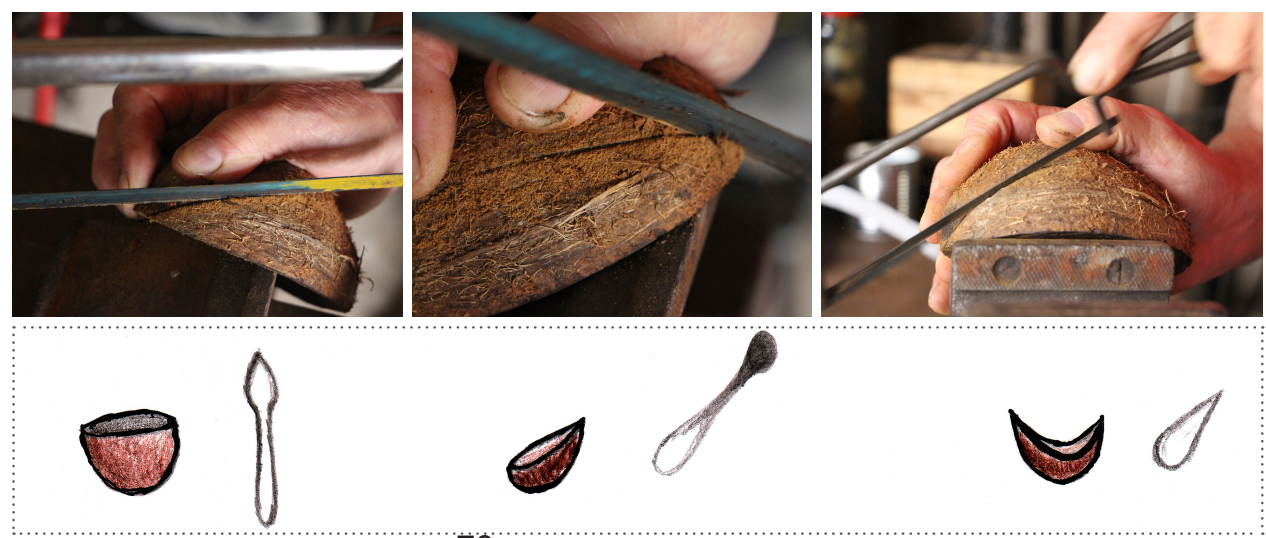


\subsubsection{Plate Design}

This dish was developed in 4 phases, applying the Double Diamond design process [1]:

$1^{\text {st }}$ Phase - Discover the characteristics of PC and taste cues to consider in the dish, investigate similar works as well results in the literature from previous studies related to taste, PC and their effectiveness. Brainstorming about possible innovation to be presented as taste dish, respecting the menu.

$2^{\text {nd }}$ Phase - Define the brainstorming results and select what really matters to the "perfect" PC, focused on the objectives and avoid distractions or references to other senses (see figure 61).

$3^{\text {rd }}$ Phase - Develop prototypes, test elements and recipes. Check the whole ergonomy of the dish, define plating, choose and discuss the best container, etc.

$4^{\text {th }}$ Phase - Delivery of the final version of the dish.

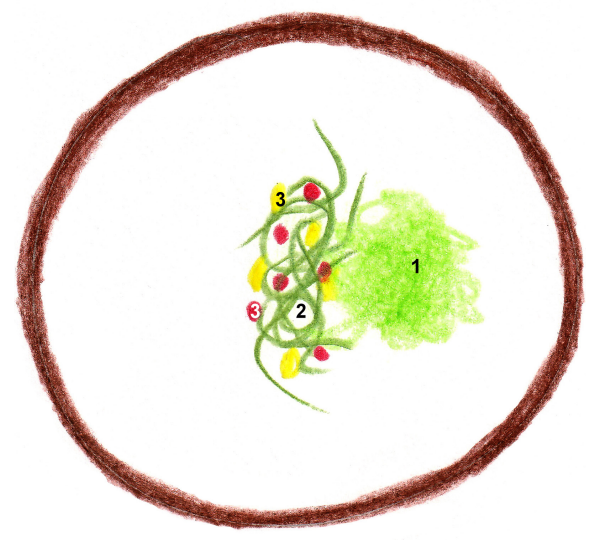

FIGURE 61. Plating Greenly Fresh draw, 2018

A coconut shell was used as container for this dish, that is mainly mono chromatic - having various shades of green - the coconut shell beig brown makes the contrast remarkable. Granita resembles snowflakes giving the information that has light weight and is cold. The apple strips are read as random lines, as if they were the branches of a tree. Being the granite slightly on top of the apple strips gives illusion of forest' humidity and freshness.

Three different plating proposals were produced, each one transmitting different inputs according to it characteristics, as angularity is associated to acidity, roundness with sweetness and organic shapes enhance the natural features on the plate [141].

Using a manual saw 3 plates were created (see figure 59). After cutting, polishing was done and containers were waterproofed with camellia oil. In spite of being cut and trimmed, the coconut shell kept the organic appearance. The exterior fibre filaments provide visual textures that increments the natural appreciation. Shape symbolism is expected to impart possible differences on flavour when tasting. The dish 1 (see figure 62) is the most angular one, with two pointy edges, and probably would impact on the acidity perception. Dish number 2 is similar to a simple bowl and being completely round with circle shapes probably would enhance the sweet sensitivity. Finally, dish 3 resembles an egg shell and has the most oraanic shape look, probablv it would enhance vegetal and herbaceous flavour [98], [115], [142].
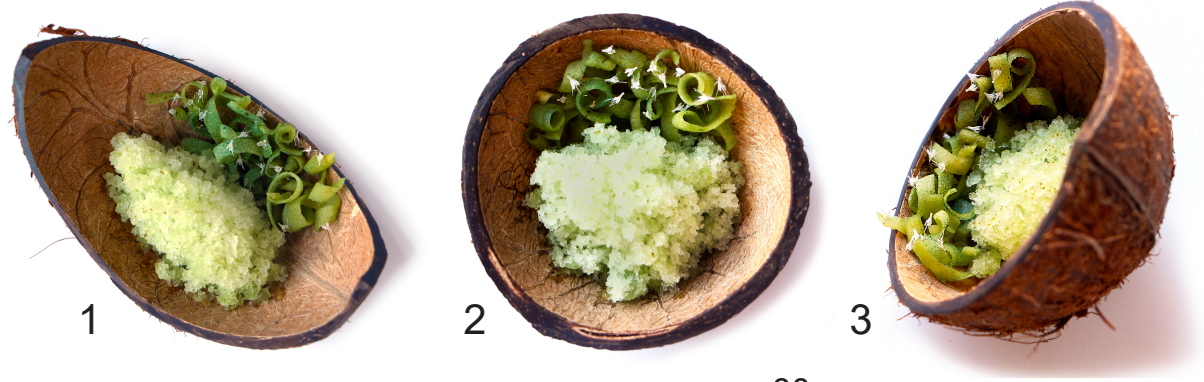
In a visual reading the dish 2 is the most balance, with power of centre, being condensed and having an equally distributed space. Dish number 3 can be considered interesting to look, represents a form of plate that is not usually seen, defies gravity and ordinary shapes, despite its vast negative space harmony is present. Finally, in dish number 1 the negative space is prevalent causing unbalance and instability on harmony.

\subsubsection{Results, evaluation, discussion and conclusions}

A granita was chosen to be the main element in this PC. Studies show that sorbets are among the most effective palate cleanser [207].

Temperature has an impact on taste perception through the triggering of cascade reactions in receptors [121], [153]. As temperature rises, perceptions of sweetness and bitterness tend to intensify, and perceptions of sourness and saltiness tend to remain the same [39], [209]. Well-known examples are the extreme sweetness of melted ice cream and the bitterness of warm beer [116]. Furthermore, it has long been known that when rested on the skin, cool objects are perceived as heavier than warm objects (Stevens ANd Green, 1978). This phenomenon is known as the Weber illusion. In this dish if ever happens the diner to hold the plate, would create a heavier impact.

Cooling agents like menthol (in peppermint) create a thermal stimulation of the oral mucosa. On the other hand, pre-incubation with menthol affects the neural responses to sucrose, inducing potentiation at low concentrations and inhibition at high concentrations, and inhibiting the responses to $\mathrm{NaCl}$, quinine, acetic acid and ethanol. These complex interactions may cause, for example, the extreme distortion of the taste perception after chewing menthol-flavoured gums. Although the mechanisms underlying these observations remain obscure, it seems clear that these effects are not related to the modulatory action of menthol on thermosensation, but to its irritating effects through the stimulation of trigeminal nerve fibres carrying noxious information from the mouth. Additionally, menthol can elicit bitter responses on their own and may therefore interact with the transduction pathways of other taste stimuli [116]. Also, according to Cowart (1998), several panelists commented that offered sparkling water was bitter. Although carbonated water is not necessarily bitter showed that other trigeminal stimuli (capsaicin and menthol in their study) produce bitter sensations in some people [210]. Therefore, presumably cold menthol in an ice cream will create more impact as well, since menthol is naturally associated with freshness and, once at a low temperature, can enhance the freshness perception.

Saliva works as an additional PC, the secretion of saliva is intensified because of the acidity [104]. Chocolate was used in previous studies to minimize the cooling effect generated from mint flavour [207], as there was chocolate on the previous dish, the main course, mint will suit as PC on this, as chocolate and mint are one of the most famous food pairing by opposition profiles. Additionally, mint essential oil was used in the granita to enhance the mint cooling effect.

The reason for the apple strips being carbonated is the fat content on the previous dish.

In the case of colour, there are taste associations that influence perceived taste [121], from simultaneous measurements of human perception and physical concentration in vivo, texture - aroma and texture - taste interactions are not always explained by physico-chemical mechanisms. Moreover aroma - taste interactions have been the subject of many studies already reviewed and are mainly explained by cognitive interactions even if in some case physico-chemical mechanisms may occur. Finally, few studies mentioned the impact of aroma and taste on texture perception. The aim of this review is to focus on the impact of aroma, taste and texture interactions on flavour perception. For each type of binary interactions (texture - aroma, aroma - texture, texture - taste, taste - texture, taste - aroma and aroma taste. People prefer to eat food in colours that seem natural and non-artificial, this is the case of green that is the only colour on the dish. Green also transmits a liquid touch by looking, a sensation of natural freshness, and predicts a bitter taste and minty aroma [100]. Represents the perfect balance between 
cold and hot colours, and it's the only colour that dispense learning process, by the variety of greens that exist on nature who unconsciously train consumers [55].

Previous studies above referred were taken in consideration when creating the recipe, however it would be interesting to confirm hypothesis through sensory analysis. However, time constraints made this impossible.

\subsection{TOUCH}

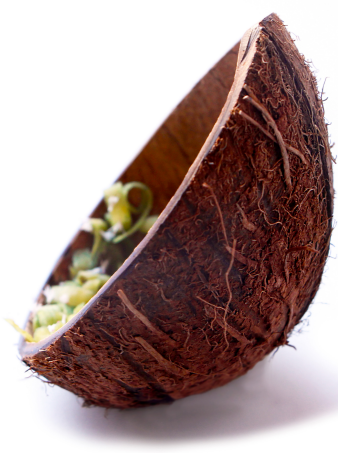

FIGURE 63. Greenly

Fresh dish, 2018

\subsubsection{Objetives}

To test how texture can affect the senses, a dessert was developed, composed by 15 different elements, in which the beetroot was the main ingredient. The idea was to have a plate based on one colour, purple, but with different tones, full of different textures, shapes and lines. Several hydrocolloids and emulsifiers were used in order to get the desired organoleptic characteristics.

In this work hydrocolloids, commonly known as gums, food additives that act as texturizers, were applied to create diverse physical characteristics on food and provide a massive tactile experience to the taster.

The perception of texture involves not only touch, but also the vision and hearing, especially for crunchy foods [63].

The tactile clues involved are the mouthfeel, texture, temperature, and trigeminal sensations. All these aspects were considered in the design of this plate.

The main propose was to focus on the Touch sense, and the strategy used for this involved using beet as the main ingredient, acting as a colouring agent, and providing camouflage to mask the clues about other ingredients which, when unraveled, could wake up, intensify and surprise the customer's senses. The development of this dish, involving the design of flavourt, consistency, texture, surface, the sound of chewing, smell and all other object properties, consisted in an exciting Food Design challenge.

\subsubsection{Dish Composition}

After reflection and inspiration in the vibrant vegetable that beetroot is, it was decided to create a subtle, light and autumnal dessert all in the same colour, using the beetroot as a natural dye. In a culinary context the beetroot can be used in many different ways, and using it in a dessert was an stimulating challenge. Apart from it's use as a dye, it was also used sliced and fried, in juice and dehydrated. There are flavours incorporated in the various elements of the dessert such as mint, honey, ginger, lemon, cinnamon, lavender and lime. However, the monotony of the colour hides this diversity of flavours, only the diversity of textures and shapes can be observed. Each edible portion of the dish has a different texture (crunchiness, smoothness etc) and they have different temperatures, which allow to enhance perception by the taster and are discovered in parallel with the hidden flavours. The 15 elements (see figure 64) were developed and cooked at the Food Lab in Faculdade de Ciências e Tecnologia of Universidade Nova de Lisboa during several weeks for (see 10.5. For full recipe). 
Figure 64. Beet

Grains Dish, 2016

1 | Lavender Ice Cream - after dehydration of the fresh lavender, a cold infusion was made with it. A cold smooth dimension was inserted with a floral aroma.

2 | Beet Fluid Gel - a gel that is blended to become a fluid gel. It has vinegar notes, which introduce flavour and acidity, a counterpart to the sweetness of the other elements, contributing to the equilibrium of the whole dessert. To obtain the fluid gel, xanthan and gellan gums were used. This gel is the filling of the macaron and also used to make some dots in the plate. The flavour is totally beetroot with some added acidity.

3 | Lemon Foam - is a siphon whipped cream with $20 \%$ lemon juice. The acidic taste balances the sweetness present in the dish. The texture is associated to a stiffed Chantilly. It is used to fill a crunchy isomalt cannelloni.

4 | Aerated Macaron - a solid and crunchy sponge made with beetroot juice that is filled with the beet fluid gel. The result is crunchy in the outside and moist in the inside.

5 | Beet Veil - here again the flavour of the beetroot is present in the thin layer of gel. mint.

6 | Orange Block - it is a piece of gel, that melts in the mouth, made with orange juice infused with

7 | Beet Air With Cinnamon - beetroot flavour pairs well with spices, in this case cinnamon, applied by cold infusion. This beet air is light in texture, so it vanishes quickly releasing volatile compounds detected by retro nasal smell.

8 | Beet Sponge Cake - is a common cake but airier, prepared with almonds, cooked beet, eggs, flour and sugar. Is a sweet solid soft sponge with beet and almond flavour.

9 | Citrus Curd - made with lemon, lime, orange juices and zest, eggs, milk and butter. The acidity from the citrus perfectly balances the fat and the sweetness, very aromatic and fresh.

10 | Honey Mousse - has flavours of mint, honey, vanilla and mascarpone. Results in a cold, smooth, creamy and light mousse, full of aroma. 
11 | Sugar Castle - is a sweet stiff French meringue, that cracks in the mouth, and is super sweet.

12 | Isomalt Cannelloni - is a rigid tube that is filled with a lemon foam, it is sweet, but no aroma was introduced, only works here as texture agent, crispy and crunchy.

13 | Crumble - has cinnamon, ginger and lime as flavouring ingredients, being a crumble has a sand like texture.

14 | Beet Chips - crunchy sweet chips, that suit well into this dessert.

15 | Dark Chocolate Ganache - has the consistency of a normal ganache being flavoured with ginger juice.

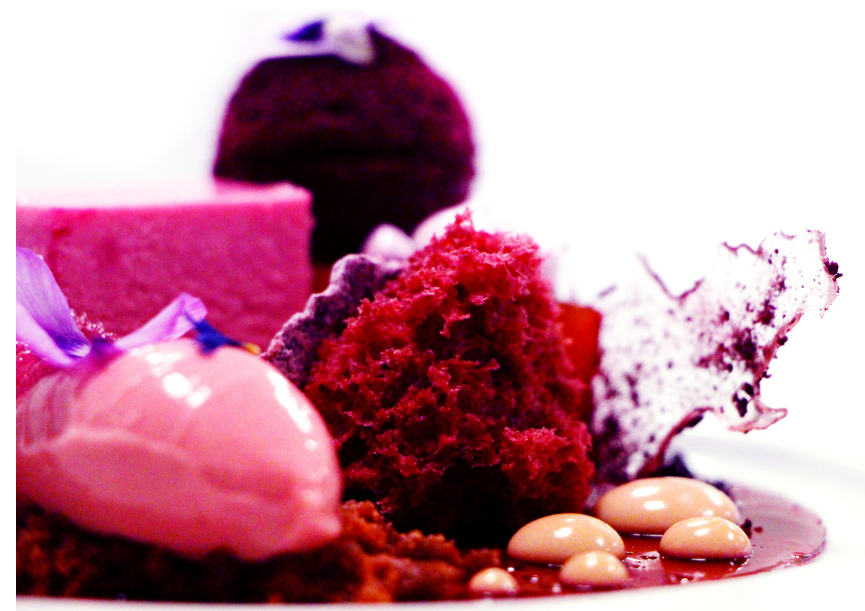

FIGURE 65. Beet

Grains Dish, 2017

\subsubsection{Techniques applied}

In order to get a wide texture range, hydrocolloids were applied, sometimes more than one per element, as presented in the table 4 .

1 | Lavender Ice Cream - Gellan F was used to slow down the ice cream from melting and to maintain its shape. At the percentage used, it doesn't introduce any perceptible difference in the mouthfeel. Gellan is usually dispersed in a warm liquid, otherwise it may become attached to the vessel. It should be dispersed along with other dry ingredients like sugar for example, or alcohol or oil. (Blumenthal, 2009). The dispersion is made with the help of mechanical stirring (wisk), leading each particle of the polysaccharide to be surrounded by water molecules (colloidal suspension). After this step, the liquid is heated to the boiling point (approximately $90{ }^{\circ} \mathrm{C}$ to $95{ }^{\circ} \mathrm{C}$ ) to break the bonds between the gellan chains, the thermally agitated polymer change into random coils In the cooling process a three-dimensional mesh is created which rearranges the double helices and forms the network junction points of the polymer. The lowering to a temperature of $32{ }^{\circ} \mathrm{C}$ to $40{ }^{\circ} \mathrm{C}$ leads to the organized aggregation of these junction points and thus creates a three-dimensional structure capable of holding water [86], [180].

Dehydration and cold infusions were also applied here in order to protect and respect the natural aromas and flavours of the lavender.

Liquid Nitrogen was used to make the ice cream, due to the low temperature $\left(-196^{\circ} \mathrm{C}\right)$ it freezes the ice cream very rapidly and thus the formed ice crystals are very small, resulting in a smother consistence. 


\begin{tabular}{|c|c|c|c|c|c|c|c|}
\hline $\begin{array}{l}\text { Hydrocolloids } \\
\text { and Texturizers }\end{array}$ & $\begin{array}{l}\text { Number } \\
\text { in the } \\
\text { image }\end{array}$ & $\begin{array}{l}\text { Where } \\
\text { applied }\end{array}$ & Concentration & Role & Synergy & $\mathrm{T}^{\circ} \mathrm{C}$ of Application & $\begin{array}{l}\mathrm{T}^{\circ} \mathrm{C} \text { of } \\
\text { Storage }\end{array}$ \\
\hline Gellan & 1,2 & $\begin{array}{l}\text { lavender ice } \\
\text { cream; beet } \\
\text { fluid gel }\end{array}$ & $\begin{array}{c}0,5 \% \text { ice cream; } \\
1 \% \text { fluid gel }\end{array}$ & $\begin{array}{l}\text { in the ice cream it } \\
\text { slows the melting rate; } \\
\text { in the fluid gel is a } \\
\text { gelling agent; in both } \\
\text { is used as a thickener }\end{array}$ & & $\begin{array}{c}\text { dispersed at } 50^{\circ} \mathrm{C} \\
\text { and dissolved at } \\
95^{\circ} \mathrm{C}\end{array}$ & $\begin{array}{l}-4^{\circ} \mathrm{C} \text { ice } \\
\text { cream; } \\
3^{\circ} \mathrm{c} \text { fluid } \\
\text { gel }\end{array}$ \\
\hline Xanthan & 2,3 & $\begin{array}{l}\text { beet fluid } \\
\text { gel; limon } \\
\text { foam }\end{array}$ & $\begin{array}{c}0.25 \% \text { beet gel; } \\
0.7 \% \text { foam }\end{array}$ & thickener & $\begin{array}{l}\text { with gellan or } \\
\text { gelatin, due to high } \\
\text { viscosity confers } \\
\text { elasticity }\end{array}$ & any $\mathrm{t}^{\circ} \mathrm{C}$ & $5^{\circ} \mathrm{C}$ \\
\hline Methylcellulose & 4 & $\begin{array}{l}\text { aerated } \\
\text { macaron }\end{array}$ & $2 \%$ & $\begin{array}{l}\text { stability to the foam } \\
\text { and film formation }\end{array}$ & & $\begin{array}{c}\text { jellifies when } \\
\text { heated above } 50^{\circ} \mathrm{C}, \\
\text { in the dehydrator } \\
\text { forms films }\end{array}$ & $50^{\circ} \mathrm{C}$ \\
\hline $\begin{array}{c}\text { Elastic } \\
\text { (kappa } \\
\text { carragenan and } \\
\text { carob gum) }\end{array}$ & 5 & beet veil & $1 \%$ & $\begin{array}{l}\text { locust bean gum in } \\
\text { beet veil promotes the } \\
\text { elasticity and } \\
\text { transparency }\end{array}$ & $\begin{array}{c}\text { Kappa carragenan } \\
\text { and locust bean } \\
\text { gum }\end{array}$ & $\begin{array}{l}\text { cold hydration; } \\
\text { dissolved at } 70^{\circ} \mathrm{C}\end{array}$ & $5^{\circ} \mathrm{C}$ \\
\hline Agar & 6 & $\begin{array}{l}\text { orange } \\
\text { gelatin }\end{array}$ & $1 \%$ & fast jellifying process & & $\begin{array}{l}\text { cold hydration; } \\
\text { dissolved at } 90^{\circ} \mathrm{C}\end{array}$ & $5^{\circ} \mathrm{C}$ \\
\hline Gelatine & 3,6 & $\begin{array}{c}\text { lemon foam, } \\
\text { orange } \\
\text { gelatine } \\
\text { block }\end{array}$ & & $\begin{array}{l}\text { as stabilizer in the } \\
\text { foam, as gelling agent }\end{array}$ & & $\begin{array}{l}\text { melted at } 35^{\circ} \mathrm{C} \text { and } \\
\text { incorporate in the } \\
\text { solutions }\end{array}$ & $5^{\circ} \mathrm{C}$ \\
\hline Sucro & 7 & $\begin{array}{l}\text { beet juice } \\
\text { air with } \\
\text { cinnamon }\end{array}$ & & emulsifier & & cold infusion & \\
\hline Egg Proteins & $\begin{array}{c}8,9,10 \\
11\end{array}$ & $\begin{array}{c}\text { beet sponge } \\
\text { cake, lemon } \\
\text { curd, honey } \\
\text { mousse, } \\
\text { meringe }\end{array}$ & & $\begin{array}{l}\text { in the sponge cake to } \\
\text { confer the solid } \\
\text { sponge texture, lime } \\
\text { curd as a gelling, in } \\
\text { the honey mousse as } \\
\text { emulsifier and gelling } \\
\text { agent }\end{array}$ & $\begin{array}{l}\text { in the lemon curd or } \\
\text { honey mousse helps } \\
\text { stabilize the foam }\end{array}$ & lime curd at $78^{\circ} \mathrm{C}$ & $5^{\circ} \mathrm{C}$ \\
\hline
\end{tabular}

TABLE 4 - Hydrocolloids and Texturizers applied at Beet Grains recipe

2 | Beet Fluid Gel - to obtain this fluid gel xanthan and gellan gums were used. The role of the xanthan is to give viscosity and thickness. Xanthan is a polysaccharide produced as a secondary metabolite naturally obtained by fermentation of the bacterium Xanthomonas campestris. The resulting product is a carbohydrate soluble in water with thickening effect and features which give great versatility in different applications [42], [215]. Noteworthy are its high viscosity at low concentrations, as well as its stability in a wide range of temperature and $\mathrm{pH}$, even in the presence of salts [86]. Xanthan prevents water exudation (syneresis), a common phenomenon in agar gels or gellan, for example [216], [217]. The solutions of xanthan gum exhibit a highly reofluidifying behavior, that is, when the rate of deformation is increased, the viscosity is progressively reduced.

If the purpose is to obtain a fluid gel, one of the techniques used consists in forming a gel structure and mixing it with a blender. This breaks the three-dimensional structure and small particles of gel are formed. Depending on the initial strength of the gel, fluid gels with different viscosities can be obtained. The fluid gel is then passed through a fine sieve to remove unbroken pieces of gel or granules of undissolved gellan. The type of gellan used for this purpose is low-acyl gellan which results in more rigid and stiff gels (for a consistent fluid gel), however, this is more sensitive to the presence of minerals than high-acyl gellan which results in less firm and less consistent gels [156]. Fluid gels allow a better release of flavours compared to the use of starch to thicken sauces, for example 
In order to prevent colour degradation, vinegar was added to the beet juice. The betalains have a similar behavior to anthocyanins, known as "chromoalcaloids" due to the presence of a nitrogen atom in the chromophore group. There are some factors that can influence the stability of these pigments as variations of $\mathrm{pH}$, temperature, presence of oxygen, light, aw, metals, etc. It is stable at $\mathrm{pH}$ between 3.5 and 5 [218]. Above $50^{\circ} \mathrm{C}$ begins the degradation of this pigments, the higher the temperature, the faster the degradation [219].

3 | Lemon Foam - siphon whipped cream foam. Gelatin and xanthan were used to stabilize the foam.

The siphon requires $\mathrm{N} 2 \mathrm{O}$ (nitrous oxide) gas cartridges, to pressurize the chamber holding the liquid. Whipping siphons were designed for aerating creams high in fat, where fat gives viscosity and in turn stabilizes foams. However, it is possible to foam any liquid thick enough to hold bubbles. Adding starch, gelatin, eggs, or agar to thin liquids can give them enough viscosity for foaming.

Gelatin is primarily used as a gelling agent forming transparent elastic thermoreversible gels on cooling below about $35^{\circ} \mathrm{C}$, which dissolve at low temperature to give 'melt in the mouth' products with useful flavour-release [220]. In addition, the amphiphilic nature of the molecules endows them with useful emulsification (for example, whipped cream) and foam-stabilizing properties (for example, mallow foam).

4 | Aerated Macaron - methylcellulose was used as an emulsifier and foaming agent, it also jellifies when the temperatures raises and the subsequent dehydration allows to obtain a solid and crunchy foam. Methylcellulose is a cellulose derived hydrophilic compound and only dissolves in cold aqueous solutions, it is used in the food industry as a thickener and emulsifier. For the production of methylcellulose, cellulose is dissolved in the reaction solution and then the alkylating agent is added with the desired substitution group. Methyl cellulose has the interesting properties of gelling when it is heated, being this process reversible if the temperature decreases. Thus, above $50^{\circ} \mathrm{C}$ the solution where the methylcellulose is dissolved will jellify, the molecules are bound by heating due to the hydrophobic interaction of the methyl groups. Once the methylcellulose comes in contact with a hot liquid to which it is added, it quickly forms a gel and this step may prevent it from being completely dissolved, so it is advisable to be first dissolved in water at $50^{\circ} \mathrm{C}$ and then added to the preparation and beat until cool [6].

5 | Beet Veil - was prepared with Elastic by Sosa (a mixture of kappa carrageen and locust bean gum), that conveys elasticity to the structure. It is widely used in the food industry and has several applications: gelling, thickening, stabilizing, and liquid retainer [221]. The gelation process of kappa carrageen starts with the cold hydration, which consists in dispersing the powder with the aid of mechanical stirring (wisk), causing each of polysaccharide particles become surrounded by water molecules (colloidal suspension). After this, the heating of the liquid until about $70^{\circ} \mathrm{C}$ allows to break the bonds between the chains of kappa carrageen and its dissolution, When temperature decreases to around $40^{\circ} \mathrm{C}$ a three-dimensional structure capable of retaining water is formed. During the cooling process a three-dimensional mesh is formed in which the double helix, initially formed, make the junction sites of the chains, so this makes the gel thermoreversible [221].

Locust bean gum is another element of Elastic by Sosa, is a polysaccharide extracted from the seeds of the vegetable Ceratonia siliqua $L$ (locust), it acts as a thickener and gels only in the presence of kappa carrageenan. The structure is formed by a main chain units of $\beta$-D-mannopyranose (linked $\beta$ - 1,4), with singular lateral branches of $\alpha$-D-galactopyranose, attached to the main chain, by $\alpha-1,6$ glycosidic bonds. The average ratio for the amounts of mannose and galactose in locust bean gum is 4: 1. The dispersion is carried out at cold, and it hydrates at temperatures above $90^{\circ} \mathrm{C}$. There is a synergy between the two that makes the gels more transparent and flexible [222].

6 | Orange Block - Agar was used as gelling agent. Agar occurs as structural carbohydrate in the cell walls of agarophytes algae. It dissolves in boiling water and on cooling $\left(\sim 35^{\circ} \mathrm{C}\right)$ forms thermo-reversible gels stable until about $85^{\circ} \mathrm{C}$. The gelling portion of agar-agar has a double helical structure. These aggregate to form a three-dimensional structure framework which holds the water molecules (up to $99.5 \%$ ) within the interstices of the framework. In the food area it is used in icings, glazes, processed 
cheese, jelly sweets and marshmallows. It may be used in tropical countries and by vegetarians as a substitute for gelatin. It is normally used in concentrations between $0.25 \%$ and $1 \%$, depending on the desired final texture. Around $0.25 \%$ to $0.5 \%$ acts as thickener and between $0.5 \%$ and $1 \%$, leads to the formation of gels with good organoleptic characteristics. Above $1 \%$ gels may become too hard and unpleasant in the mouth and hinder the release of flavour [223].

7 | Beet Air With Cinnamon - Flavours were applied by cold infusion and a sucroester (Sucroemul by Sosa) was used for foam stabilization. Sucroesters are compounds obtained by esterification of sucrose with a fatty acid. Modifying the degree of esterification allows to obtain emulsifiers with HLB (hydrophilic-lipophilic balance) values of 1 to 16 . The SOSA product contains sucrose molecules esterified with high HLB and is therefore able to create good oil in water emulsions and air in water foams. After an initial dispersion in the aqueous phase to form a colloidal suspension, mechanical agitation will introduce air and thee sucrose esters at the interface between water and air reduce the surface tension of water, thus stabilizing the foam.

8 | Beet Sponge Cake - using a siphon gas is incorporated in the cake batter, which is then cooked in the microwave for about 30 seconds. Egg proteins act as foam stabilizers. Microwave cooking allows a rapid expansion of the foam and its stabilization due to coagulation of proteins and gelatinization of starch.

9 | Citrus Curd - is made using the sous vide technique at $78^{\circ} \mathrm{C}$ and gelatin is used to enhance the gels the structure resulting from the eggs proteins. Egg proteins are globular, the heat denatures them and they become distended and create connections in certain points and form a gel. The firmness of the gel depends on the $\mathrm{pH}$ of the medium, the temperature and the concentration of the proteins The temperature and extension of coagulation can be modified by adding others ingredients, such as water or milk, causing a dilution of proteins, or other hydrocolloids that interfere with the protein network formation [224].

12 | Isomalt Cannelloni - Isomalt, produced by chemical modification of sucrose, is an equimolar mixture of two disaccharide alcohols gluco-mannitol and gluco-sorbitol. Isomalt, looks like table sugar, it is white, crystalline and odourless and is ideal for sugar art, sugar blowing and decorations because it is humidity resistant, it stays clear and does not caramelize Products made with isomalt have considerable durability and shelf life and higher gloss when compared to those made with regular sugar.

15 | Dark Chocolate Ganache, was made without any added fat because, instead of cream, beet juice and inverted sugar were used for a shiner result.

Chocolate has a large percentage of fat, cocoa butter, which repels the water, has sugar that creates affinity with water, and has cocoa particles that can create affinity with water, chocolate has lecithin in its composition, an amphiphilic molecule. When melted chocolate contacts with small amounts of water viscosity increases as the sugar molecules become associated with the moisture forming clusters. However, if more water is added the texture becomes uniform, as a phase inversion of the emulsion occurs. As chocolate has some emulsifiers this emulsion becomes stable [7], [10]. That is how this ganache was made with beet juice containing more than $80 \%$ water. 


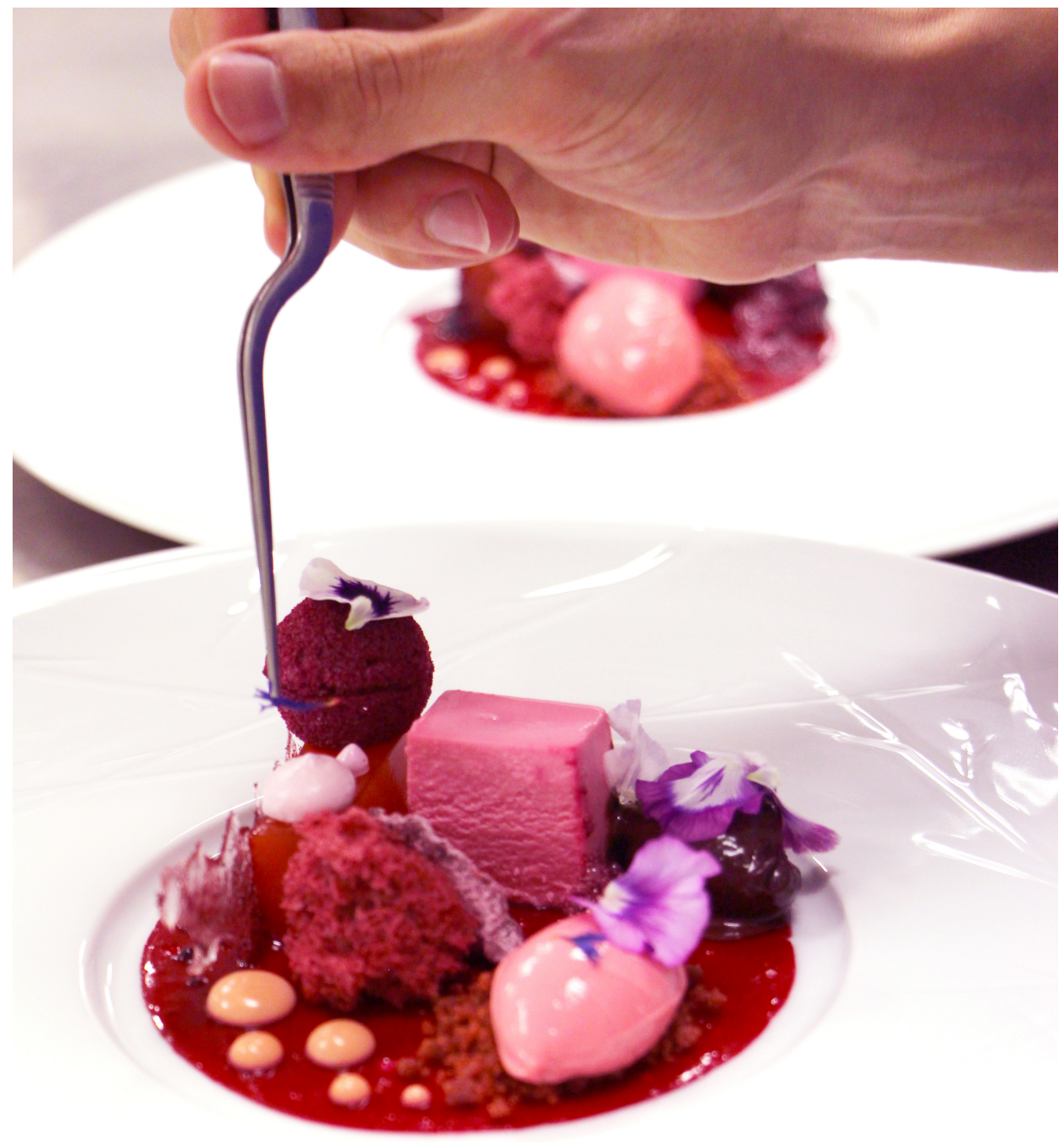

FIGURE 66. Plating

Beet Grains Dish,

Ritzs Four Seasons

Lisbon, 2017

\subsubsection{Plate Design}

In the plating process three options were proposed, with more or less contrast in colours and also with different lines defined by the components, this allowed distinct visual composition readings and made some of them more attractive than the others. These proposals were discussed in a small group composed by supervisors and the student.

As seen in Figure 67, proposal A loses the contrast between the plate and the various elements. their monochromaticy, makes difficult to read the textures, all that can be perceived is a set of volumes. The perception is more straightforward for proposal $B$, it is also cleaner, but at the same time it loses a bit of balance, for example in proposal $A$ the balance is given by the dark purple circle of beet veil that totally filled the base of the plate. Proposal $\mathrm{C}$ is the one with more visual noise, the contrast of the plate colour with the pink citrus curd involving the other elements transmits imbalance.

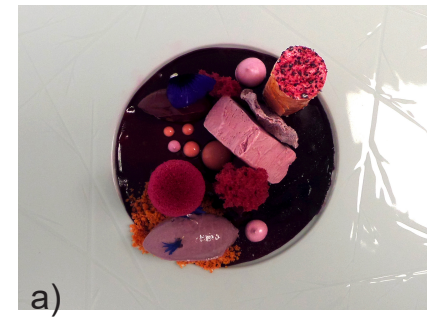

b)

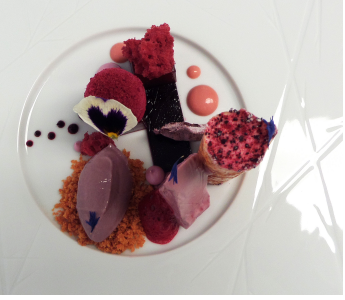

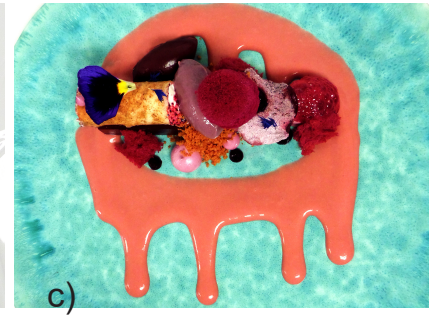

FiguRE 67. Different platings of Beet Grains dish, 2016 
Based on these prototypes suggestions were given for the final proposal.

This dish was developed in 4 phases, applying the Double Diamond design process [1]:

$1^{\text {st }}$ Phase - Discover how to make tactile cues to be consider in a dish, search for cooking techniques, investigate trigeminal sensations.

$2^{\text {nd }}$ Phase - Define the brainstorming results and select what really matters to the touch sense.

$3^{\text {rd }}$ Phase - Develop prototypes, test elements and recipes

$4^{\text {th }}$ Phase - Delivery the final version of the dish and which was submitted to a focus group with Ritz Four Season Chefs.

\subsubsection{Results}

A dish is a tip of the iceberg that represents the planning and development steps, from the initial point until the final product. The final dish here presented was the result of several months of projection and reflection, involving the elaboration of multiple tests, crossing flavours, finding good suppliers, designing presentation, thinking about the esthetical aspects of the presentation, organizing the logistics of the whole process, etc. In fact, is the result of a long and complex process of food design.

\subsubsection{Focus Group for evaluation}

On the 28th October 2017, at Ritz Four Seasons Hotel, 5 stars luxury hotel in Lisbon, a focus group was organized in which 6 senior and experienced Chefs participated: Executive Pastry Chef, Executive Cuisine Chef, Pastry Sub Chef, Cuisine Sub Chef, Cuisine Chef of Partie and Pastry Chef of Partie.

The dish was presented to each chef and the following topics were considered:

- Identification and evaluation of the textures perceived;

- Evaluation of the combination of textures and global evaluation;

- Discussion the characteristics of the sensory experience;

- Suggestions to improve the dish;

FIGURE 68. Beet

Grains dish, Ritzs

Four Seasons Lisbon,

2017

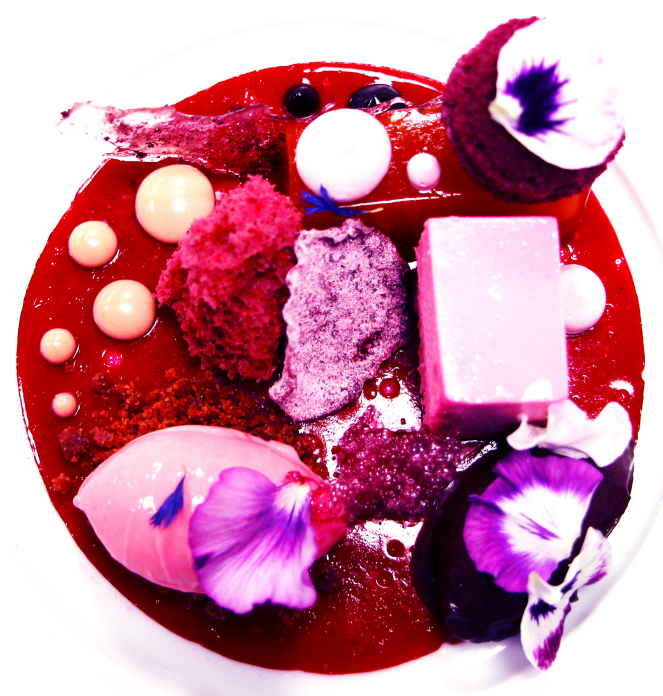


The global appreciation of Executive Pastry Chef Fabian Nguyen, was that the dish for its academical purpose was perfect, however it was not totally appropriate for a fine dining restaurant, for this purpose it should be improved.

The dish was considered visually very beautiful. All the participants considered the dish very well plated and without any fault. They considered that visually it reminds San Valentin's day.

They considered that the perfect presentation creates high expectation that these were not completely fulfilled particularly due to aspects related to flavour, texture and unbalance.

They considered that there were too much different flavours, and this resulted a bit confusing, Each element is complex and conveys a story and it was difficult to perceive such complexity. Usually consumers can only identify a limited amount of flavours and it is important to avoid the combination of more than 2 or 3 flavours at a time. Less flavours would allow to achieve balance. The ice cream was considered bitter and too intense. The honey and mint mousse was their favourite combination as it reminded a fresh and smooth mojito.

Considering the textures, the aerated macarron was considered extremely interesting due to its velvety texture. However, the crumble was not crunchy anymore when it was served, the isomalt cannelloni was sticky to teeth, the ice cream should be colder, and the ganache reduced to half portion when plated. Vegetal jellies should be avoided in order to respect the flavour release.

In their opinion, although valid for academic purposes, there was a too strong focus in demonstrating cooking techniques and knowledge, and thebalance was lost.

Their suggestions were mainly to simplify and to focus only on 2 or 3 elements and plate smaller portions, to work further on food pairing and its textures. The final result should be as simple as possible and touch the taster mind, providing a clear reading of flavours and textures. Their advice was that it is always important to create, to taste and to get better and that this was a good starting point to develop.

Their advices were of extreme importance and encouragement, even considering that the dish developed was not intended to be served at a restaurant, it was very complex for such purpose, although was an academic exercise.

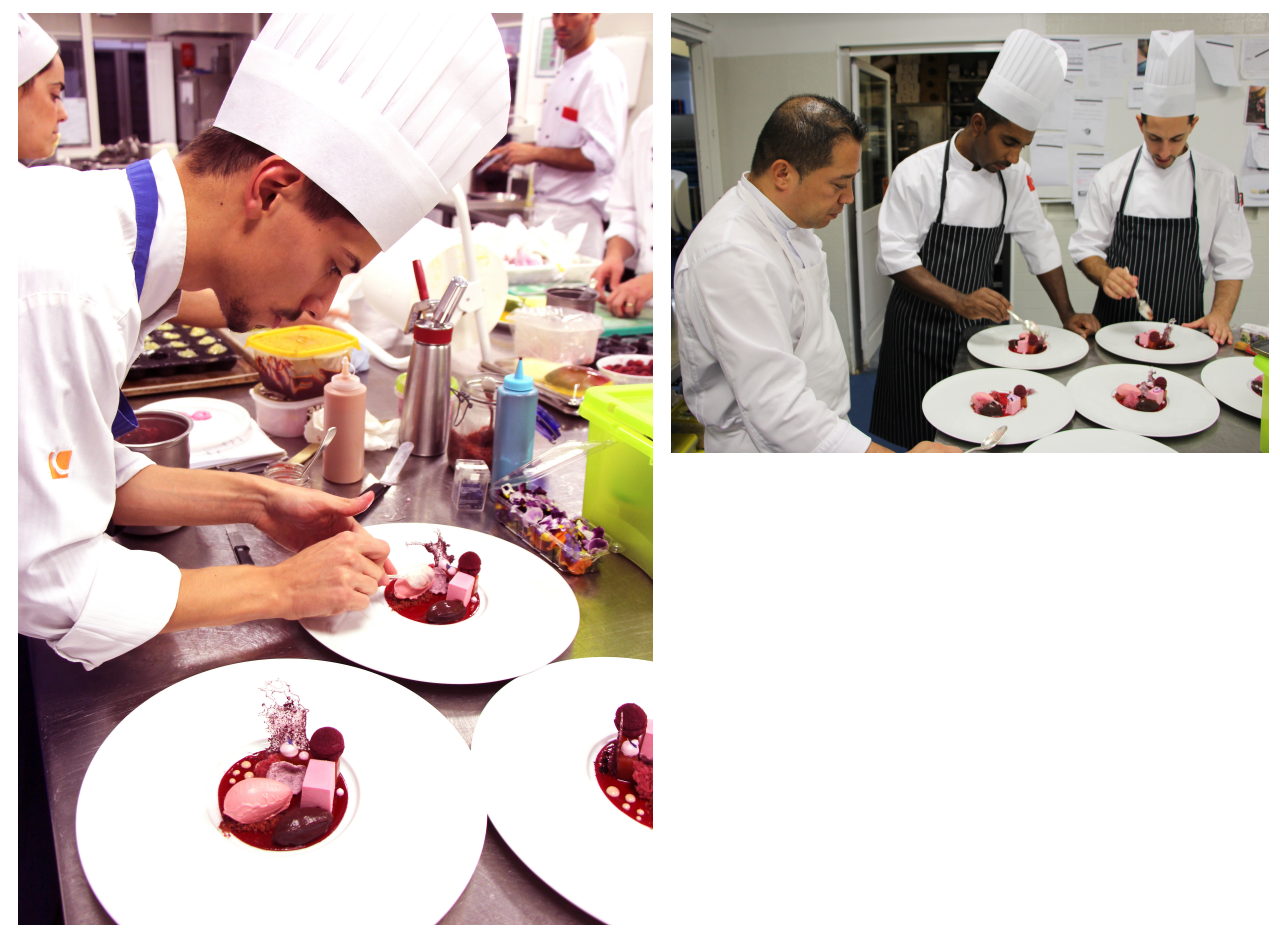

FIgURE 69. Plating Beet Grains Dish, Ritzs Four Seasons Lisbon, 2017

Figure 70. Focus groups with Chefs, Ritzs Four Seasons Lisbon, 2017 


\subsubsection{Discussion and Conclusion}

There is a close relationship between beetroot and the soil, which is very inspiring, but this vegetable has other characteristics that should not be ignored from the nutritional, cultural and culinary point of view. For us is one of the most beautiful and challenging food products and therefore was chosen to develop this dish. The option for not inserting other colours, or creating a chromatic contrast in the composition, is related to the aims of the dish in the context of this academic work. In this case the chromatic monotonous dish in which the beetroot colour masks other colours could create simple visual expectations. Therefore this "illusion" would generate an unexpected sensory shock to the customer. In fact when enjoying the dish, the customer will discover a range of different textures either visual or noticed by the tongue with flavours incorporated into each element. This surprise element awakes the senses resulting in a better sensory experience, and even intellectual appreciation. One dramatic way to make a diner focus on the texture of the food is by removing any colour cues from the dish, letting the diner discover the flavour of the foods via their texture, perceived through their hands and mouth (one might also consider that dining in dark restaurants achieves a similar goal by different means) [145], [146].

Relevant in this regard are the 'White funeral' meals organized by chef-artist Marije Vogelzang. They consist entirely of white food and specially designed white crockery, which enable one to focus on the visual, tactile, and oral texture of the foods served [63]. Subsequently, all the taste sense will be more precise and mindful, as soon as there are various flavours, the tactile experience was disturbed [104]. The use of incongruity between the appearance of foods (and beverages) and their flavour or aroma has currently spread out among chefs as a resourceful tool to give rise to deliver surprise [63].

The whole composition of food products is very complex. Foods contain proteins and carbohydrates which are constituted, respectively, by amino acids and, in the case of polysaccharides, by several sugars bound together. These elements are responsible for the structure and type of connections to be established, and for their interaction with other constituents of the system. The texture is the result of the internal structure of food, which is determined by their intermolecular relationships of constituents [200], [222], [225]. Adding hydrocolloids, which have different compositions and therefore different functions and properties, allows to modify and enrich the textural characteristics.

The hydrocolloids used in this dish allow to convey a range of different rheological properties, resulting in a variety of textures, and this is an important aspect that influences and increases the pleasure provided to the consumer. Their hydrophilic capacity allows them to interact significantly with the free water in the solution where they are applied, thereby reducing their mobility and increasing the viscosity of the solutions [215], [226]. The use of some thickening and gelling agents reduce the flavour release and perception since the used aroma compounds can be retained due to increased viscosity and gel structure [104]. This aspect must be considered when using these texturizers to take advantage of their multiple properties keeping as much flavour as possible.

The texture of food plays a key role in its appreciation, being as important as gustatory, olfactory and visual sensations. Thus, for the Touch it is possible to work variations of textures and temperatures. Texture and temperature contrasts are explored in cooking to awake the senses and increase perception. For example a hot and cold liquid, that do not mix and surprise the consumer, as in the Hot n' Cold Tea from The Fat Duck menu [6], or a spherification a technique used to turn liquids into edible spheres in which the liquid is enclosed by thin flexible membranes. This sphered blow inside the mouth, an example are the Aceitunas Explosivas from El Bulli [30], [73], [86].

At the focus group, one of the Chef of Partie said that the mint mousse reminded her of mojito flavour, this happens when food or drink is being evaluated, assimilation may occur if the discrepancy between what was expected and what was perceived is small [147].

Even if there are 15 elements on this dish the equilibrium can be obtained by varying elements and values, which is equivalent to a compensation equilibrium [52]. Thus informal balance follows the clear hierarchy identified by dimensions, heights or positioning of an element in relation to the set of elements of 
the whole composition [61]. However, complexity becomes interesting when it balances entropy and order.

In addition, if sharpness, diffusion, proportion, contrast and variety result in balance, agreement and uniformity, the visual effect is pleasant due to the well-ordered and organized layout referring to all features, scale, sequence, proportion, symmetry, conformity and consistency. All parts of the composition relate and complete into a coherent whole, that allows for a simple and clear reading [61]. This was why the visual composition of this dish was widely appreciated.

Finally, the purple tones on the dish influence its perceptions. Colour has its own meaning and influence the perception of texture, temperature and even the distance between foods. Colour can induce sensations of heat or cold, dry or damp, smooth or rough, soft or hard etc. According to Ricco (2008) "the temperature of a colour is determined by its tendency towards yellow (hot colour pole)" or blue (cold colour pole) this can justify the perception of the temperature of the ice cream, considered not as cold as desirable, despistes being at $-13^{\circ} \mathrm{C}$, the purple tone was unconsciously associated to hot colour pole.

Psychologists, together with modernist chefs and a growing number of food and beverage producers, are currently trying to make plateware and/or packaging that, by more effectively stimulating the sense of touch, manages to enhance the diner's (or consumer's) experience of food and drink. An example of plateware that may successfully achieve this goal is Nao Tamura's silicone leaf plates, whose texture resembles that of a leaf, possibly making the eating experience more natural [63]. A better understanding of how texture and mouthfeel are perceived should allow nutritionists, dietitians and food manufacturers to predict food acceptance in a more systematic way [127]. 


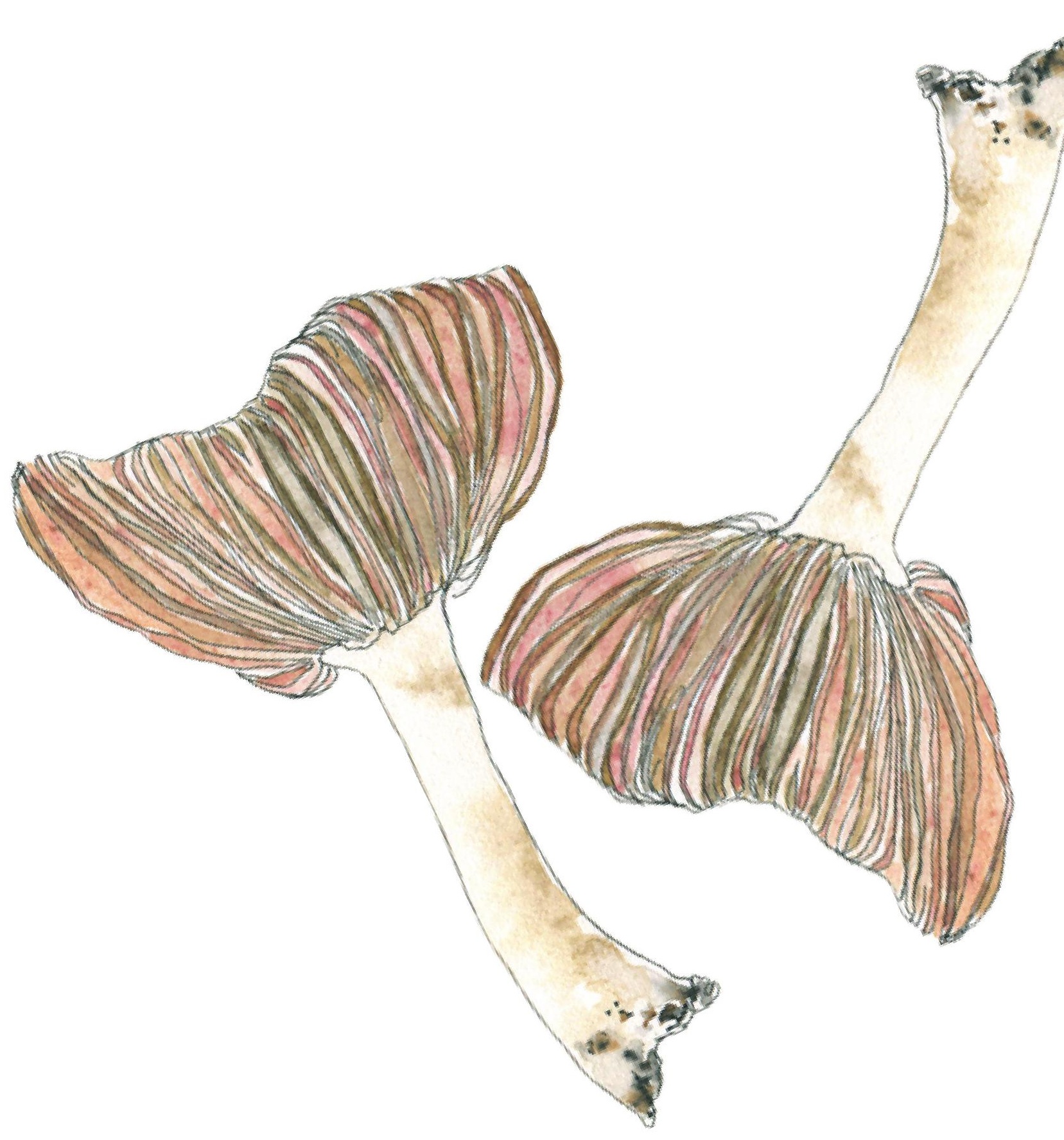




\section{CONCLUSION}

Whether in restaurants, kitchen laboratories, markets or bars, chefs should be aware that flavour does not lie only in the ingredients. As a meal is a multi-sensory experience, the flavour is much more than what goes into the mouth. There are several senses and sensations affecting flavour perception. Senses such as touch, sight, hearing, smell and taste, and sensations such as emotions, nostalgia, context and expectation affect flavour perception.

A work of cooperation, teamwork, between specialists of different areas that assume the role of participants in the creative process is important. Among others: cooks, chefs, technicians, designers and scientists, can contribute for exploring the food and the context in which it is presented, to create something new. The dish, the final product, should be the key that can seduce the eyes of a potential consumer and then satisfy, or even surpass expectations. According to SPENCE (2017), the sight influences more than anything else.

Man creates, not only because he wants, or because he likes, but because he needs. In fact, he can only grow, as a human being, coherently, organized, giving form and creating. Ferran Adriá refers that "Creativity is not copying". Art and science should work in symbiosis with cooks to maximize gastronomic pleasure of clients, the benefits of this join work are endless and can open windows that lead to the extraordinary [30], [48].

Paola Antonelli asks if cooking is an art or a job, defending that art is free of limits, and cooking has to meet certain expectations or fulfil certain functions [96]. Whether cooking is art or not, it is considered a world in which the cook is a designer and food a language to those who accept to interpret it.

Cooking is a language that allows cooks to express themselves, thus the creative chefs take risks since their creations may not be accepted. Chefs do not create dish by dish, the goal is to open new paths through techniques and concepts, creations are established to stimulate senses. For example, touch is the aim when the chef handles textures and temperatures. The culinary action goes beyond the physical and the sensory and focuses also on the emotional and intellectual aspects, through humour, provocation, reflection, memory and nostalgia.

For the author, the concept of cooking is a way of being in life, productivity represents his character, "we are what we do and how we do." A dish is a tip of the iceberg that has to be planned and requires several steps for being created. The final product is the consequence of several months of planning and reflection, with the elaboration of multiple tests, pairing flavours, finding good suppliers, designing presentation, thinking about food design, organizing the logistics of the whole process, its ergonomics, etc. Several aspects must be present and optimized, they are Harmony in a whole, Beauty elevated to the extreme, Complexity to stimulate the mind, Provocation of the senses, Contrast that creates emotion, Culture that reveals knowledge, Happiness to influence the state of mind, Creativity as key to success, Quality to raise the final product, Technique which demonstrates mastery, Gastronomic value by respecting the products, strong Vegetal component for the sustainability, Light cuisine full of flavour with neutral foods and Art in the eyes of the consumer. 
Personal curiosity combined with the passion for cooking leads to creativity, a touch of willingness allows to do more and better, creating art!

The main objective of creating a cinematic menu with five dishes, inspired on the woods and in which each dish represents a different part of the day, was accomplished. While designing this menu, it was important to figure out how to use the latest insights from gastrophysics to create a better tasting experience. Science knowledge, from different areas (for instance, molecular gastronomy, food design, physics, chemistry, biochemistry, physiology and neuroscience) was also required, in fact it is used nowadays in the kitchen as a tool to control the development of new dishes and of new techniques by some professional chefs. This transdisciplinary knowledge is of extreme importance to chefs, as it allows to understand processes, create, get better results and more complex creations and, ultimately, enhance the experience of eating.

The developed work related to Sight, Mooning Walk, demonstrates that technologies can be used to deliver an intense multisensory dining experience. An experience that can simultaneously is innovative and creative, creating interest, arousing curiosity and involving emotions. Also, the shape of the leaf / plate used and all its visual interaction to food, including the lighting and colours, constitute a decisive factor influencing perception. While changing the lightning from blue to yellow, expectations can change by the associations of blue to cold and yellow to hot food. A floating fig's leaf with food on it has a high degree of complexity associated, it would be important to undertake further studies to understand its impact on the eating experience.

Research related to the Smell dish confirm that chefs must be aware of the power of smell and should concentrate in working how to enhance and deliver it in order to achieve a better multisensory experience. Also, this olfactory design study suggests that the shape of containers, as well as its ergonomics can modify the aroma and smell perception. A container with a wine glass shape was identified as the best for enhancing the olfactory perception of the dish. The results of this research were applied on conception, execution, and commercialization of a porcelain piece by Vista Alegre Portuguese Company. Product Designers should be aware of these and so many other insights about gastrophysics in order to produce tools to be used by chefs to improve the overall multisensory experience.

The Sounds of the Forest dish, focused on the Hearing sense, was designed considering the knowledge that sound can draw taster's attention to some aspects of the tasting experience and hence highlighting them. Applying the right music or right tones can "season" the multisensory experience, music influences tastes perception and can create and influence emotions, feelings and subconscious actions which are going to deeply influence the perception of food.

The Taste dish, a palate cleanser, increased the awareness about the required characteristics of a palate cleanser, that should be defined by those of the previous dish in order to obtain an effective neutralization of palate. In fact, it consists on the key to recover senses and prepare them for the upcoming dish and beverage. Watery and acid ingredients are the best to applied on an efficient palate cleanser.

Finally, for the Touch sense a monochromatic dish was created to reduce expectations resulting from vision. Human oral-somatosensory system is complex and sensitive, being sensations delivered by food textures, which are in turn defined by culinary techniques, design and biological matrix of ingredients. The use of texturizers and hydrocolloids allowed to impart the desired textural characteristics.

Apart from the individual conclusion about each dish on its chapters, as conclusion it can be said that in spite of having considered the senses in isolation in this work, most of what is experienced in the real world involves more than one sense, if not all the senses simultaneously. Thus, although each dish was focuses in one of the senses, the global perception involved all of them. Relatively to the topic of food aesthetics, which is nowadays very relevant. Design knowledge allowed to explore a scientific approach to aesthetic plating, functions and ergonomics. "Cooking is designing food" [78]. 
The work for this dissertation also involved two internships at La Masia from El Celler de Can Roca and at the L'Air du Temps. These provided a better understanding of how complex modernist restaurants and the multisensory experience of eating are.

Results from the evaluation of the influence of the characteristics of the containers in aroma perceptions could be applied during the IDPool artistic residence at Vista Alegre. This allowed facing a completely new reality and through the cooperation between all the participants of the residence it was possible to reach the aims. Two containers were developed which one of them was included in Vista Alegre Chefs collection.

The author is a cook and this allows him to study and apply the gastrophysics approach on food design in a realistic way, for instance when creating a dish, by establishing its ergonomics or even deciding on how to stage a dining experience. His previous Michelin path has defined his character as as a compulsive seeker to achieve perfection and how t giveíng extreme importance to details. Getting out of the comfort zone on exploration of other areas such as product design in the production of porcelain pieces, statistics, colour psychology, thermography and magnetism, ended up by eventually overcoming the expectations first established.

Certainly, the recourse to this work process will continue to grow in the years to come. Culinary schools should therefore consider teaching certain basic principles of science, art and aesthetics, as an integral part of the skills that any chef should have.

Digital technologies will constitute an increasingly common feature of the dining table of the future. Research is being done in this area, for example, Chef Juan Maria Arzak, in collaboration with scientists, have been exploring how the eating experience can be enhanced or altered by stimulating the senses using the integration of electronics, light, and other stimuli [87]. Simultaneously and in parallel with such research on the use of digital technology to improve eating experience, food sustainability is something that starts to concern population, scientists and chefs. Alternative proteins will have to be introduced for human consumption, like insects and vegetables proteins, agriculture will be associated to technology generating shorter production cycles that occupy less space such as hydroponics. These are new challenge for chefs, and the work methodology above referred can be extremely useful to overcome them.

The perfect meal is yet to come. 
[20] J. L. Flandrin and M. Montanari, História da Alimentação Vol. I - Dos primórdios à Idade Média. Lisboa: Terramar, 1998.

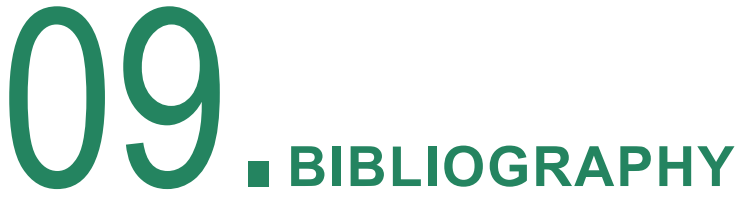

[1] Design Council, 'The Double Diamond', 2017. [Online] Available: https://www.designcouncil.org.uk/. [Accessed 16-Jan-2018]

R. Mota, P. Mata, H. Vilaseca, R. Bonacho, and M. Carvalho, 'Designing for the senses through food design and psychophysiology', Exp. Food, Des. Dialogues, 2017.

J. Briscione, The Great Cook: Essential Techniques and Inspired Flavors to Make Every Dish Better. London, UK Cooking Light, 2016.

F. Parasecoli, P. Reissig, and F. Zampollo, 'Second International Food Design Confenrence', in The New School, 2016.

[5] K. Lebesco and P. Naccarato, The Hanbook of Food and Popular Culture. New York: Bloomsbury, 2018.

H. Blumenthal, The Big Fat Duck Cookbook. London, UK: Bloomsbury, 2008.

[7] H. McGee, On Food and Cooking : the science and lore of the kitchen. EUA: Scribner U.S., 1984.

C. Spence, Gastrophysics - The new science of eating. Oxford, England: Viking, 2017.

C. Spence and B. Piqueras-Fiszman, The Perfect Meal: The multisensory science of food and dinning, First edit. Oxford, England: John Wiley \& Sons, Ltd, 2014.

[10] H. This, 'Formal descriptions for formulation', Journal, Int., vol. 344, pp. 4-8, 2007.

[11] S. Stummerer and M. Hablesreiter, Eat Design. Berlin: Metro Verlag Wien, 2013.

[12] R. J. Courtine, Larousse Gastronomique. Lisboa: Círculo de Leitores, 1990.

[13] M. Montanri, II Cibo come Cultura. Laterza, 2006

[14] M. Sen, Luzes e Sombras do Reinado de Ferran Adrià. São Paulo: Senac São Paulo, 2009.

[15] J. A. Brillat-Savarin, Fisiologia do Gosto. Lisboa, 2010.

[16] M. Toussaint-Samat, A History of Food, New Expand. Paris: Wiley-Blackwell, 2009.

[17] E. Neirinck and P. Jean-Pierre, Historia da la Cocina y de los Cocineros. Barcelona: Editorial Zendrera Zariquiey, 2001.

[18] H. Carneiro, "'Comida e Sociedade: significados sociais na história da alimentação"', in 42, 2005, pp. 71-80.

[19] R. Diez-Garcia and I. Castro, “'A Culinária como objeto de estudo e de intervenção no campo da Alimentação e Nutrição"', Cien. Saude Colet., vol. 16, no. 1, 2011.
[21] B. Wilson, A história da invenção na cozinha. Lisboa: Círcu lo de Leitores, 2012.

[22] A. Franco, De caçador a gourmet - Uma história da Gastronomia. São Paulo: SENAC, 2001.

[23] C. Alva, Historia de la gastronomía. México: Red Tercer Milenio, 2012.

[24] A. B. Nascimento, Comida, Prazeres Gozos e Transgreções. Salvador: EDUFBA, 2007

[25] A. Rodrigues, 'Apício, De Re Coquinaria I-III: Introdução, Tradução e Notas, Trabalho de conclusão de curso', Faculdade de Letras da Universidade Federal do Rio Grande do Sul, 2010.

[26] S. Oliveira, 'A Importância da Gastronomia na Deslocação de Visitantes - estudo de caso: Mealhada', Universidade de Aveiro, 2008

[27] B. Beaugé, 'On the idea of novelty in cuisine. A brief historical insight', Int. J. Gastron. Food Sci., vol. 1, pp. 5-14, 2011.

[28] M. Flandrin, Jean Louis Montanari, História da Alimentação Vol. II - Da Idade Média aos tempos actuais. Lisboa: Terramar, 2001.

[29] W. Constantine, 'Un histoire Culinaire: Careme, The restaurant, and the birth of modern gastronomy', State University-San Marcos, 2012.

[30] M. Lozano, 'El acto de comer en el arte - del eat art a Ferran Adrià en la Documenta 12', Universidade Complutense de Madrid, 2013.

[31] H. A. Mallory, 'The Nouvelle Cuisine Revolution: Expressions of National Anxieties and Aspirations in French Culinary discourse 1969 - 1996', Duke University, 2011.

[32] M. Steinberger, Au Revoir to All That: The Rise and Fall of French Cuisine. EUA: Bloomsbury, 2010.

[33] D. Cassi, 'Science and cooking: the era of molecular cuisine', Sci. Soc. Ser. Food Sci., vol. 12, no. 3, pp. 191-196, 2011.

[34] F. D. Bona, 'Comida como obra de arte: da revolução futurista à nouvelle cuisine', Rev. X, vol. 2, pp. 52-60, 2007.

[35] J. Abrams, 'Mise en Plate: The scenographic imagination and the contemporary restaurant', Perform. Res. A J. Perform. Arts, vol. 18, no. 7, pp. 7-14, 2013.

[36] E. van der; Linden, J. . Ubbink, and D. J. McClements, 'Molecular Gastronomy: A Food Fad or an Interface for Science-based Cooking?', Food Biophys., vol. 3, no. 2, pp. 246-254, 2008.

[37] $\quad H$. This, Kitchen Mysteries Revealing the Science of Cooking. New York: Columbia University Press, 2007.

[38] C. Vega and J. Ubbink, 'Molecular gastronomy: a food fad or science supporting innovative cuisine?', Food Sci. Tecnol., vol. 19 , no. 7 , pp. $372-382,2008$

[39] H. This, Molecular Gastronomy: Exploring the Science of Flavour. Colombia: University Press, 2006. 
[40] I. de Solier, 'Liquid nitrogen pistachios: Molecular gastronomy, elBulli and foodies', Eur. J. Cult. Stud., vol. 13, no. 2, pp. $55-150,2010$

[41] M. P. Opazo, 'Discourse as driver of innovation in contemporary haute cuisine: The case of elBulli restaurant', Int. J. Gastron. Food Sci., vol. 1, pp. 82-89, 2003.

[42] J. Moura, Cozinha com ciência e arte. Lisboa: Bertrand Editora, 2011.

[43] A. Martinho, 'A Gastronomia como ferramenta para uma Cidade Criativa: Projeto de uma Cooking Factory', FAUTL, 2012

[44] R. Redzepi, René Redzepi: A Work in Progress. Phaidon Press, 2013.

[45] R. Redzepi, Noma: Time and Place in Nordic Cuisine. Phaidon Press, 2010.

[46] M. Raymond, CrEATe: Eating, Design and Future Food. Berlin: Die Gestalten Verlag, 2008.

[47] M. Clintberg, 'The Artist's Restaurant: taste and the Performative Still Life', Concordia University from Montreal, 2013.

[48] J.-P. Jouary, Ferran Adria and El Bulli: The Art, the Philosophy, the Gastronomy, 1st editio. Andre Deutsch Ltd, 2013.

[49] I. Chilvers and J. Glaves-Smith, A Dictionary of Modern and Contemporary Art. UK: Oxford University Press, 2009.

[50] M. P. Opazo, Appetite for Innovation: Creativity \& Change at elBulli. New York: Columbia University Press, 2016.

[51] C. Catterall, Food: Design and Culture. London, UK: Laurence King, 1999

[52] C. Michel, C. Velasco, E. Gatti, and C. Spence, 'A taste of Kandinsky: assessing the influence of the artistic visual presentation of food on the dining experience', Flavour, vol. 3, no. 1, p. 7, 2014

[53] Apicus, Cookery and dining in Imperial Rome. New York: Dover Publications, 1936

[54] J. F. Delwiche, 'You eat with your eyes first', Physiol. Behav. vol. 107, no. 4, pp. 502-504, 2012.

[55] B. Watz, 'The entirety of the meal: a designer's perspective', J. Foodserv., vol. 19, pp. 96-104, 2008.

[56] L. Gustafsson, I.-B., Öström, Å., Johansson, J. and Mossberg, 'The Five Aspects Meal Model: a tool for developing meal services in restaurants', J. Foodserv., vol. 17, pp. 84-93, 2006.

[57] F. Aleu, el somni del celler de can roca. Barcelona, Spain, 2014

[58] S. I. D. F. SVID, 'Definition of design', 2017. [Online]. Available: http://www.svid.se/en/What-is-design/Definition-of-design/.

[59] G. Bonsiepe, Interface: An approach to design. Maastricht: Jan van Eyck Akademie, 1999

[60] D. A. Dondis, Sintaxe da linguagem visual. São Paulo: Martins Fontes, 2007
[61] W. Wong, Principles of Form and Design. New York: John Wiley \& Sons, Ltd, 1993.

[62] J. B. Hutchings, Colour in food. 2017

[63] C. Spence, C. Hobkinson, A. Gallace, and B. P. Fiszman, 'A touch of gastronomy', Flavour, vol. 2, no. 1, p. 14, 2013.

[64] B. Munari, Das coisas nascem coisas, 7th ed. Lisboa: Martins Fontes, 2010.

[65] R. Arnheim, Art and Visual Perception: A Psychology of the Creative Eye. University of California Press, 2004.

[66] F. J. Gomes, Gestalt do Objeto: Sistema de leitura visual da forma, Escrituras. São Paulo, 2003.

[67] C. Swann, 'Research and the Practice of Design', Des Issues, vol. 18, no. 1, pp. 49-61, 2002.

[68] N. Cross, Designerly Ways of Knowing, Vol. 3, No. Massachusetts Institute of Technology: Design Studies, 1982.

[69] N. Cross, Developments in Design Methodology. Chichester: John Wiley \& Sons, Ltd, 1984.

[70] A. F. Osborn, Applied Imagination. Principles and Procedures of Creative Problem-Solving. Hadley, Massachusetts: Creative Education Foundation Press, 1953.

[71] J. S. Horng and Y. C. Lee, 'What environmental factors influence creative culinary artists?', Int. J. Contemp. Hosp. Manag., vol. 21, no. 1, pp. 100-117, 2009.

[72] M. Guixé, Food Designing. Milan: Corraini Edizioni, 2010

[73] F. Adrià, 'Cooking and Science Go Hand in Hand', in Cooking Science, Condensed Matter, Barcelona: Actar, 2010.

[74] J. C. Jones, Design methods, Second. London: David Fulton Publishers, 1970

[75] B. D. Rosso, 'Creativity and Constraint: Exploring the Role of Constraint in the Creative Processes of New Product and Technology Development Teams', ProQuest Diss. Theses, p. 187,2011

[76] M. Ottenbacher and R. J. Harrington, 'The innovation development process of Michelin-starred chefs', Int. J. Contemp. Hosp. Manag., vol. 19, no. 6, pp. 444-460, 2007.

[77] R. J. Harrington and M. C. Ottenbacher, 'Managing the culinary innovation process: The case of new product development', J. Culin. Sci. Technol., vol. 11, no. 1, pp. 4-18, 2013

[78] J. Capella, Tapas - spanish design for food. Barcelona: Sociedad Esatal de Accion cultura, SA, 2015.

[79] V. Margolin, '“Design in History"', Des. Issues, vol. 25, no. 2 pp. 94-105, 2012.

[80] F. Parasecoli, Food cultural studies, and popular culture. Abindon, UK: Routledge, 2013.

[81] G. Bosoni, Italy: Contemporary Domestic Landscapes. Milan, 2000.

[82] M. Celi and S. Palmieri, Advanced Design Cultures. Milan: Springer International Publishing, 2016. 

intercambios entre Europa y América. Pamplona: Asociación Española de Americanistas/Newbook Ediciones, 1998

[84] F. Zampollo, Meaningful eating: a new method for food design. London, UK: London Metropolitan University, 2013.

[85] M. Vogelzang and L. Schouwenberg, Eat Love: Food Concepts. Amsterdam: BIS Publishers, 2008.

[86] N. Myhrvold, C. Young, and M. Bilet, Modernist Cuisine. EUA: The Cooking Lab, 2011.

C. Spence and B. Piqueras-fiszman, 'Technology at the dining table', Flavour, vol. 2, no. 16, pp. 1-13, 2013

[88] S. A. Goehrke, '3D Print Me a (Space) Pizza! A Few Questions For: BeeHex', 3Dprint.com, 2016. [Online]. Available: https://3dprint.com/124802/a-few-questions-for-beehex/.

[89] S. Soares, 'Insects Au Gratin', 2015. [Online]. Available: http://www.susanasoares.com/index.php?id=82.

[90] B. Hobson, 'One day we will be able to 3D-print a hamburger', Dezeen magazine, 2013.

[91] B. Hobson, '3D-printing with living organisms "could transform the food industry', Dezeen Magazine, 2015.

[92] D. Van Der Linden, '3D Printing Makes Food Unique', TNO inovation for life, 2016. [Online]. Available: https://www.tno. nl/en/focus-area/healthy-living/food-nutrition/food-innovations/3d-printing-makes-food-unique/.

[93] J. Ray, 'How To Get 3D Printing Into Your Kitchen - Food Printing', 3Dprinting.com, 2015. [Online]. Available: http:// 3dprinting.com/food/how-to-get-3d-printing-into-your-kitchen-food-printing/.

[94] J. Luimstra, 'Scientists 3D Printed Two Jet Engines', 3Dprinting.com, 2015. [Online]. Available: http://3dprinting.com/ news/scientists-3d-printed-two-jet-engines/.

[95] S. Forstner, 'From Puree to 3D - The EU Performance Project Presents Results', 3Dprinting.com, 2015.

[96] S. Parreira, 'Design-en-Place: Processo de design e proces so criativo na alta cozinha', Universidade de Lisboa, 2014.

[97] R. Hamilton and V. Todolí, Food for thought, thought for food. Barcelona: Actar, 2009.

[98] M. Bar, Moshe; Neta, 'Humans prefer curved visual objects', Psychol. Sci., vol. 17, no. 8, pp. 645-648, 2006.

[99] F. Birren, 'Color and human appetite', Food Technol, no. 17 pp. 45-47, 1963.

[100] D. Riccò, Sentire II Design: Sinestesie nel progetto di comunicazione. Carocci, 2008.

[101] C. Spence et al., 'On tasty colours and colourful tastes? Assessing, explaining, and utilizing crossmodal correspondences between colours and basic tastes', Flavour, vol. 4, no. 1, p. 23,2015

[102] S. Stummerer, Food Design XL. New York: Springer Wien, 2010

[103] B. Kaufmann, Die Sinne, 'Senses, The Five', 1899. [Online]. Available: www.jewishencyclopedia.com/articles/13428-sensesthe-five.
[104] E. Guichard, C. Salles, M. Morzel, and A.-M. Le Bon, Flavour : from food to perception, First edit. UK: John Wiley 6 Sons, Ltd, 2017.

[105] C. Spence, 'Crossmodal correspondences: A tutorial review', Attention, Perception, Psychophys., vol. 73, no. 4, pp. 971-995, 2011.

[106] O. Spence, Charles; Deroy, 'On the shapes of flavours : A review of four hypotheses', Theor. Hist. Sci., vol. 5, no. Ed. Nicolaus Copernicus University, pp. 207-238, 2013.

[107] K. K. Evans and A. Treisman, 'Natural cross-modal mappings between visual and auditory features', J. Vis., vol. 10, no. 1, pp. 6-6, 2011

[108] C. Crisinel, Anne-Sylvie ; Spence, 'A fruity note: Crossmodal associations between odors and musical notes', Chem. Senses, vol. 37, pp. 151-158, 2012.

[109] C. Spence and A. Gallace, 'Tasting shapes and words', F Q Prefer., 2011.

[110] M. Gilles, Walker Evans: the Hungry Eye. New York: Abrams, 1993.

[111] M. Mesz, Bruno; Trevisanô, Marcos A ; Sigman, 'The taste of music', Perception, vol. 40, pp. 209-219, 2011.

[112] X. Wan, A. T. Woods, J. J. F. Van Den Bosch, K. J. McKenzie, C. Velasco, and C. Spence, 'Cross-cultural differences in crossmodal correspondences between basic tastes and visual features', Front. Psychol., vol. 5, no. DEC, pp. 1-13, 2014.

[113] G. Hanson-Vaux, A. S. Crisinel, and C. Spence, 'Smelling shapes: Crossmodal correspondences between odors and shapes', Chem. Senses, vol. 38, no. 2, pp. 161-166, 2013.

[114] H. S. Seo et al., 'Cross-modal integration between odors and abstract symbols', Neurosci. Lett., vol. 478, no. 3, pp. 175-178, 2010.

[115] D. Deroy, Ophelia; Valentin, 'Tasting liquid shapes: Investigating the sensory basis of cross-modal correspondences', Chemosens. Percept., vol. 4, no. 3, pp. 80-90, 2011.

[116] K. Talavera, Y. Ninomiya, C. Winkel, T. Voets, and B. Nilius, 'Influence of temperature on taste perception', Cell. Mol. Life Sci., vol. 64, no. 4, pp. 377-381, 2007.

[117] G. H. Liang, Pei; Roy, Soumyajit; Chen, Meng Ling; Zhang, 'Visual influence of shapes and semantic familiarity on human sweet sensitivity', Behav. Brain Res., vol. 253, pp. 42-47, 2013

[118] C. Spence and Q. Wang, 'Wine and music (II): can you taste the music? Modulating the experience of wine through music and sound', Flavour, 2015.

[119] J. H. F. Bult, R. A. de Wijk, and T. Hummel, 'Investigations on multimodal sensory integration: Texture, taste, and orthoand retronasal olfactory stimuli in concert', Neurosci. Lett., vol. 411, no. 1, pp. 6-10, 2007.

[120] C. Michel, A. T. Woods, M. Neuhäuser, A. Landgraf, and C. Spence, 'Rotating plates: Online study demonstrates the importance of orientation in the plating of food', Food Qual. Prefer., vol. 44, pp. 194-202, 2015. 
[121] C. Tournier, C. Sulmont-Rosse, and E. Guichard, 'Flavour perception: aroma, taste and texture interactions', Food, vol. 1, no. 2, pp. 246-257, 2007

[122] K. Holt-Hansen, 'Taste and pitch', Percept. Mot. Skills, vol. 27, pp. 59-68, 1968.

[123] C. Demangeot and A. J. Broderick, 'Consumer Perceptions of Online Shopping Environments', Psychol. Mark., vol. 30, no. 6 , pp. 461-469, 2010.

[124] A. C. Guyton and J. E. Hall, Textbook of medical physiology, 11th ed. Philadelphia, PA, USA: Elsevier's Health Sciences, 2006 .

[125] R. Jowitt, 'the Terminology of Food Texture', J. Texture Stud., vol. 5, no. 3, pp. 351-358, 1974.

[126] M. B. Frøst and T. Janhøj, 'Understanding creaminess', Int. Dairy J., vol. 17, no. 11, pp. 1298-1311, 2007.

[127] J. X. Guinard and R. Mazzucchelli, 'The sensory perception of texture and mouthfeel', Trends Food Sci. Technol., vol. 7, no. 7, pp. 213-219, 1996.

[128] B. . Slocombe, 'Cross-modal tactile-taste interactions in food evaluations', Neuropsychologia, 2016.

[129] C. Spence, B. Piqueras-fiszman, C. Michel, and O. Deroy, 'Plating manifesto ( II ): the art and science of plating', Flavou, vol. 3, no. li, pp. 1-12, 2014

[130] S. B, Taste what you're missing: the passionate eater's guide to why good food tastes good. London, UK: Free Press, 2012.

[131] L. Biggs, G. Juravle, and C. Spence, 'Haptic exploration of plateware alters the perceived texture and taste of food', Food Qual. Prefer., vol. 50, pp. 129-134, 2016.

[132] H. Finck, The Aesthetic Value of the Sense of Smell. Anaheim, Riverside, San Diego: The Century Magazine, 1880 .

[133] R. Linforth, 'The Impact of a Droplet of Flavour', in H. Blumenthal, The Fat Duck Cookbook, London, UK: Bloomsbury, 2008, p. 483.

[134] R. Stevenson, 'Phenomenal and access consciousness in olfaction', 2009

[135] H. McGee, On Food and Cooking: An Encyclopedia of Kitchen Science, History and Culture. London: Hodder and Stoughton Ltd, 2004.

[136] F. Benzi, 'The Flavourist', in H. Blumenthal, The Fat Duck Cookbook, London, UK: Bloomsbury, 2008, pp. 476-478.

[137] O. Deroy, A.-S. Crisinel, and C. Spence, 'Crossmodal correspondences between odors and contingent features: odors, musical notes, and geometrical shapes.', Psychon. Bull. Rev., vol. 20, no. 5, pp. 878-96, 2013

[138] G. Morrot, F. Brochet, and D. Dubourdieu, 'The color of odors', Brain Lang., vol. 79, no. 2, pp. 309-320, 2001.

[139] C. Spence, 'On the psychological impact of food colour', Flavour, 2015

[140] J. M. B. Lopes, 'Cor e Luz', Instituto Superior Técnico - Universidade Técnica de Lisboa, 2003.
[141] O. Deroy and C. Spence, 'Crossmodal correspondences: Four challenges', Multisens. Res., vol. 29, no. 1-3, pp. 29-48, 2016.

[142] E. Piqueras-Fiszman, Betina; Alcaide, Jorge; Roura and C. Spence, 'Is it the plate or is it the food ? Assessing the influence of the color ( black or white) and shape of the plate on the perception of the food placed on it', Food Qual. Prefer., vol. 24, no. 1, pp. 205-208, 2012.

[143] A. T. Woods, F. Marmolejo-Ramos, C. Velasco, and C. Spence, 'Using single colors and color pairs to communicate basic tastes II: Foreground-Background color combinations', Iperception., vol. 7, no. 5, pp. 1-20, 2016.

[144] M. K. Spence, Charles; Ngo, 'Assessing the shape symbolism of the taste, flavour, and texture of foods and beverages', Flavour, vol. 1, p. 12, 2012.

[145] A. Prikhodko, 'Lights Out, Taste Up: The Journey of Dining in the Dark', Paste Magazine, 2017. [Online]. Available: https://www.pastemagazine.com/articles/2017/06/dining-in-the-dark-the-journey-of-taste-sound-and.html.

[146] C. Spence and B. Piqueras-fiszman, 'Dining in the dark', Psychologist, vol. 25, no. 12, pp. 888-891, 2012.

[147] C. Knöferle, Klemens M.; Spence, 'Crossmodal correspondences between sounds and tastes', Psychon. Bull. Rev., vol. 19, pp. 992-1006, 2012.

[148] C. Spence, 'Sound Design: Using Brain Science to Enhance Auditory \& Multisensory Product \& Brand Development', ( ABA ) Audio Brand. Acad. Yearb. 2010/2011, pp. 33-51, 2011.

[149] K. A. Lindquist, A. B. Satpute, and M. Gendron, 'Does Language Do More Than Communicate Emotion?', Curr. Dir. Psychol. Sci., vol. 24, no. 2, pp. 99-108, 2015.

[150] C. Spence, Sound: The Forgotten Flavor Sense. Elsevier Ltd, 2016.

[151] E. Wheeler, Tested sentences that sell. New York: Prentice \& Co. Hall, 1938.

[152] B. Stuckey, Taste what you're missing: The passionate eater's guide to why good food tastes good. London, UK: Free Press, 2012.

[153] B. Piqueras-Fiszman and C. Spence, Multisensory Flavo Perception: From Fundamental Neuroscience Through to the Marketplace. UK: Elsevier Ltd., 2016.

[154] C. Ngo, Mary K.; Velasco, D. Salgado, Alejandro; Boehm Emilia; O'Neill, and C. Spence, 'Assessing crossmodal correspondences in exotic fruit juices: The case of shape and sound symbolism', Food Qual. Prefer., vol. 28, no. 1, pp. 361-369, 2013 .

[155] J. Chandrashekar, M. A. Hoon, N. J. P. Ryba, and C. S Zuker, 'The receptors and cells for mammalian taste', Nature, vol. 444, no. 7117, pp. 288-294, 2006.

[156] H. Blumenthal, The Fat Duck Cookbook. London, UK: Bloomsbury, 2009.

[157] G. M. Shepherd, Neurogastronomy. New York: Columbia University Press, 2013

[158] F. M. da C. Leonor, 'Effect of Nostalgia Triggered by Sound - from the Sound of the Sea dish - on Flavour Perception', Estoril Higher Institute for Tourism and Hotel Studies, 2014 
[159] A. C. Gil, Métodos e técnicas de pesquisa social, vol. 264. 2008.

[160] C. Dawson, Pratical research methods: A user-friendly guide to mastering research. Oxford, England: How To Books Ltd, 2008.

[161] H. Espirito-Santo, 'Regras de escrita de trabalhos escolares, trabalhos de investigação científico e dissetações de mestrado', Instituto Superior Miguel Torga, 2009.

[162] E. L. Silva and E. M. Menezes, 'Metodologia da Pesquisa e Elaboração de Dissertação', Florianóp. Laboratório ensino a distância da UFSC, vol. 29, no. 1, p. 121, 2001.

[163] J.-P. Gabriel and S. H. Degeimbre, L'Air Du Temps: Cooking \& Casting - Sang Hoon Degeimbre. Belgium: Edition Francoise Blouard, 2007.

[164] S. H. Degeimbre, 'L'air du temps', 2018. [Online]. Available: http://airdutemps.be/. [Accessed: 10-May-2016]

[165] J. Roca, J. Roca, and J. Roca, El Celler De Can Roca. Barcelona: Grub Street Cookery, 2016.

[166] J. Wong, 'Janice Wong', 2017. [Online]. Available: https:// www.janicewong.com.sg/. [Accessed: 10-Mar-2018].

[167] C. Velasco, C. Michel, A. T. Woods, and C. Spence, 'On the importance of balance to aesthetic plating', Int. J. Gastron. Food Sci., vol. 5-6, pp. 10-16, 2016.

[168] M. Doi, 'Chapter 8: Investigation into the Kokumi Taste of Soup Stock Materials', in Biochemical sensors: mimicking gustatory and olfactory senses, K. Toko, Ed. Singapore: Pan Stanford Publishing, 2013.

[169] L. Berlman, Handbook of fluorescence spectra in aromatic molecules, Vol. 1. New York: Academic Press, 1965.

[170] M. Sauer, J. Hofkens, and J. Enderlein, Fluorescence: Handbook of fluorescence imaging. Weinheim: Wiley- $\mathrm{VCH}$ Verlag $\mathrm{GmbH} \&$ Co. KGaA, 2011.

[171] J. R. Lakowicz, Principles of fluorescence spectroscopy. Baltimore, Maryland, USA: Springer, 2006.

[172] F. . Johnson, The luminescence of biological systems Washington, D.C: Amer. Assoc, Adv. Sci., 1955.

[173] et all Schmillen, A., Luminescence of organic substances. Berlin: Hellwege Verlag, 1967.

[174] M. D. Simon, L. O. Heflinger, A. K. Geim, and C. A. Torrance, 'Diamagnetically stabilized magnet levitation', Am. J. Phys., vol. 69, no. 6, pp. 702-713, 2001.

[175] M. T. Thompson, 'Eddy current magnetic levitation', IEEE Potentials, pp. 40-46, 2000.

[176] M. V. Berry and A. K. Geim, 'Of flying frogs and levitrons', Eur. J. Phys., vol. 18, no. 4, pp. 307-313, 1997.

[177] Briggs H., 'Nose can detect one trillion odours', BBC News Online, 2014.

[178] A. . Bushdid, C.; Magnasco, M.O.; Vosshall, L.B.; Keller 'Humans can discriminate more than 1 trillion olfactory stimuli', Science (80-. )., vol. 343, pp. 1370-2, 2014.
[179] J. J. . Gibson, The senses considered as perceptual systems. Boston: Houghton Mifflin, 1966.

[180] C. Spence, 'Just how much of what we taste derives from the sense of smell?', Flavour, vol. 4, no. 1, p. 30, 2015

[181] C. Spence, 'Enhancing the experience of food and drink via neuroscience-inspired olfactory design', Senses Soc., vol. 12, no. 2, pp. 209-221, 2017

[182] C. Shankar, MU; Levitan, CA; Spence, 'Grape expectations: the role of cognitive influences in color-flavor interactions', Conscious. Cogn., vol. 19, no. 1, pp. 380-390, 2010.

[183] A. P. da Cunha, M. T. Nogueira, O. R. Roque, and J. M. G. Barroso, Plantas aromáticas e óleos essenciais: composição e aplicações. Lisboa: Fundação Calouste Gulbenkian, 2012.

[184] J. D. Culbertson et al., Handbook of Food Science, Technology, and engineering. New York: Taylor \& Francis Group, 2006

[185] M. H. G. Canteri and A. De P, 'Pectina : da Matéria-Prima ao Produto Final', vol. 22, pp. 149-157, 2012.

[186] R. Santos and I. Arez, Vista Alegre Porcelanas Portuguesa. Aveiro: Estar Editora, 1998.

[187] R. Filipe, Vista Alegre - Transpor a Forma, Prolongar o Uso. Aveiro: Caleidoscópio, 2017.

[188] B. Munari, Artista e Designer. Laterza, 2001

[189] I. Standard, 'Sensory analysis - Methodology - Ranking', ISO, vol. Second edi, no. Switzerland, 2006

[190] I. Standard, 'Sensory analysis - Guidelines for the use of quantitative response scales', ISO, vol. Second edi, no. Switzerland, 2003.

[191] C. Wan, Xiaoang; Zhou, Xi; Woods, Andy T; Spence, 'Influence of the glassware on the perception of alcoholic drinks', Food Qual. Prefer., vol. 44, pp. 101-110, 2015.

[192] S. Vilanova, Mar; Vidal, Pablo; Cortés, 'Effect of the glass shape on flavor perception of "toasted wine" from ribeiro (NW Spain)', J. Sens. Stud., vol. 23, no. 1, pp. 114-124, 2008

[193] C. Spence and X. Wan, 'Beverage perception and consumption: The influence of the container on the perception of the contents', Food Qual. Prefer., vol. 39, pp. 131-140, 2015.

[194] K. A. A. . Woortmann, The symbolic meaning of food. Gastronomy: courteous and re-courteous. 2004

[195] H. Ventanas, Sonia; Mustonen, Sari; Puolanne, Eero; Tuorila, 'Odour and flavour perception in flavoured model systems: Influence of sodium chloride, umami compounds and serving temperature', Food Qual. Prefer., vol. 21, no. 5, pp. 453-462, 2010.

[196] A. M. . Adhikari, Koushik; Hein, Karen A.; Elmore, Janelle R.; Heymann, Hildegarde; Willott, 'Flavor threshold as affected by interaction among three dairy-related flavor compounds', J. Sens. Stud., vol. 21, no. 6, pp. 626-643, 2006.

[197] C. S. Sell, 'Chapter 4: The Sense of Smell in Our Lives Chemistry and the Sense of Smell', in Chemistry and Sense of Smell, New Jersey, EUA: John Wiley \& Sons, Ltd, 2014, p. 480 . 
[198] C. M. Appelqvist I.A.M; Poelman A. A. M; Cochet-Broch, M.; Delahunty, 'Impact of model fat emulsions on sensory perception using repeated spoon to spoon ingestion', Physiol. Behav., vol. 160, pp. 80-86, 2016.

[199] R. W. Moncrieff, 'Olfactory adaptation and odour likeness', J.Physiol., vol. 133, pp. 301-316, 1956.

[200] H. N. J. Schifferstein, 'What design can bring to the food industry', Int. J. Food Des., vol. 1, no. 2, pp. 103-134, 2016.

[201] J. BeMiller and R. Whistler, 'Starch: Chemistry and Technology', in Food Science and Technology, USA: Elsevier's Science \& Technology, 2009.

[202] O. R. Fennema, Y. H. Hui, M. Karel, P. Walstra, and J. R. Whitaker, 'Complex Carbohydrates in foods', in Food Science and Technology, New York: Marcel Dekker, Inc, 1999.

[203] L. Gouveia, A. Raymundo, A. P. Batista, I. Sousa, and J. Empis, 'Chlorella vulgaris and Haematococcus pluvialis biomass as colouring and antioxidant in food emulsions', Eur. Food Res. Technol., vol. 222, no. 3-4, pp. 362-367, 2006.

[204] A. Raymundo, A. P. Batista, and I. Sousa, 'Rheology Applied to Food Product Design', in Advances in Rheology Research, M. D. T. Pérez, Ed. Cambridge, UK: Nova Science Publishers, 2017, pp. 63-118.

[205] E. O. Afoakwa, Chocolate Science and Technology. 2010.

[206] F. Chemat, N. Rombaut, A. G. Sicaire, A. Meullemiestre, A S. Fabiano-Tixier, and M. Abert-Vian, 'Ultrasound assisted extraction of food and natural products. Mechanisms, techniques, combinations, protocols and applications. A review', Ultrason. Sonochem., vol. 34, pp. 540-560, 2017.

[207] R. F. Carvalho, R. Van Ee, and A. Touhafi, 'TASTE - Testing Auditory Solutions Towards the Improvement of the Tasting Experience Testing Auditory Solutions towards the improvement of the Tasting Experience', 10th Int. Symp. Comput. Music Multidiscip. Res., 2013.

[208] M. R. Parker, D. Feng, B. Chamuris, and R. F. Margolskee, 'Expression and nuclear translocation of glucocorticoid receptors in type 2 taste receptor cells', Neurosci. Lett., pp. 2-7, 2014.

[209] E. Ileri-Gurel, B. Pehlivanoglu, and M. Dogan, 'Effect of Acute Stress on Taste Perception: In Relation with Baseline Anxiety Level and Body Weight', Chem. Senses, vol. 38, no. 1, pp. 27-34, 2013.

[210] L. Verhagen, JV; Engelen, 'The neurocognitive bases of human multimodal food perception: Sensory integration.', NeurosciBiobehav, no. 30, pp. 613-650, 2006.

[211] Y. Seo, H. S. Kwak, M. Kim, Y. Jeong, and Y. Lee, 'Effectiveness of palate cleansers on various alcoholic beverages', Inst. Brew. Distill., vol. 121, no. October 2014, pp. 474-480, 2015.

[212] T. A. Vilgis, 'Texture, taste and aroma: multi-scale materials and the gastrophysics of food', Flavour, vol. 2, no. 1, p. 12, 2013.

[213] B. G. Green, 'Heat as a Factor in the Perception of Taste, Smell, and Oral Sensation', in Nutritional Needs in Hot Environments: Applications for Military Personnel in Field Operations., M. BM, Ed. Washington DC: National Academies Press (US), 1993.
[214] E. A. Johnson and Z. Vickers, 'The effectiveness of palate cleansing strategies for evaluating the bitterness of caffeine in cream cheese', Food Qual. Prefer., vol. 15, pp. 311-316, 2004.

[215] C. L. Lucak, 'Determination of various palate cleanser efficacies for representative food types', The Ohio State University, 2008.

[216] C. L. Lucak and J. F. Delwiche, 'Efficacy of Various Palate Cleansers with Representative Foods', Chem. Percept., vol. 2, pp. 32-39, 2009

[217] J. A. Evans, Frozen Food Science and Technology. UK: Blackwell Publishing Ltd, 2008.

[218] M. Schorr, B. Valdez, and R. Zlatev, Scientific, Health and Social Aspects of the Food Industry. Rijeka, InTech, 2012

[219] G. O. Phillips and P. A. Williams, Handbook of Hydrocolloids. Cambridge, UK: Woodhead Publishing Limited, 2000.

[220] I. A. Challen, 'Xanthan gum: A multifunctional stabilizer for food products', in Food Hydrocolloids: Structure, properties, and functions, New York: Plenum Press, 1994, pp. 135-140.

[221] B. Katzbauer, Properties and applications of xanthan gum. Polymer Degradation and Stability. Phaidon Press, 1998.

[222] I. A. F. Matos, D. C. Macedo, S. Ciaboti, L. A. Pereira, and C. A. Alvarenga, Avaliação da Composição centesimal de folhas de Beterraba Comparadas com Espinafre. Uberaba: II Seminário Iniciação Científica - IFTM, 2009.

[223] G. M. C. Emerenciano, M. L. D. R. De Souza, and N. do P. Franco, 'Avaliação de técnica de defumaçao para mexilhão Perna perna: análise sensorial e rendimento', Bol. do Inst. da Pesca, vol. 34, no. 2, pp. 213-219, 2008.

[224] D. A. Ledward, 'Gelation of gelatin, in Functional properties of food macromolecules', J. R. Mitchell D. A. Ledward, pp. 171-201, 1986.

[225] V. L. Campo, D. F. Kawano, D. B. D. S. Silva, and I. Carvalho, Carrageenans: Biological properties, chemical modifications and structural analysis-Review. Carbohydrate Polymers, 2009.

[226] M. M. P. M. Alves, 'Estrutura e comportamento reológico de gelatinas em associação com outras gomas alimentares', Universidade do Porto, 2001.

[227] M. Lesch, Texture: Hydrocolloid Recipe Collection. Khymos, 2010.

[228] A. L. Lígia M. Saraiva, 'Ovo - cozinha', Inst. Tecnol. química e biológica, 2001.

[229] J. Chen, 'Food oral processing: Some important underpinning principles of eating and sensory perception', Food Struct., vol. 1, no. 2, pp. 91-105, 2014.

[230] W. R. Miller, 'The definition of design', 1988 


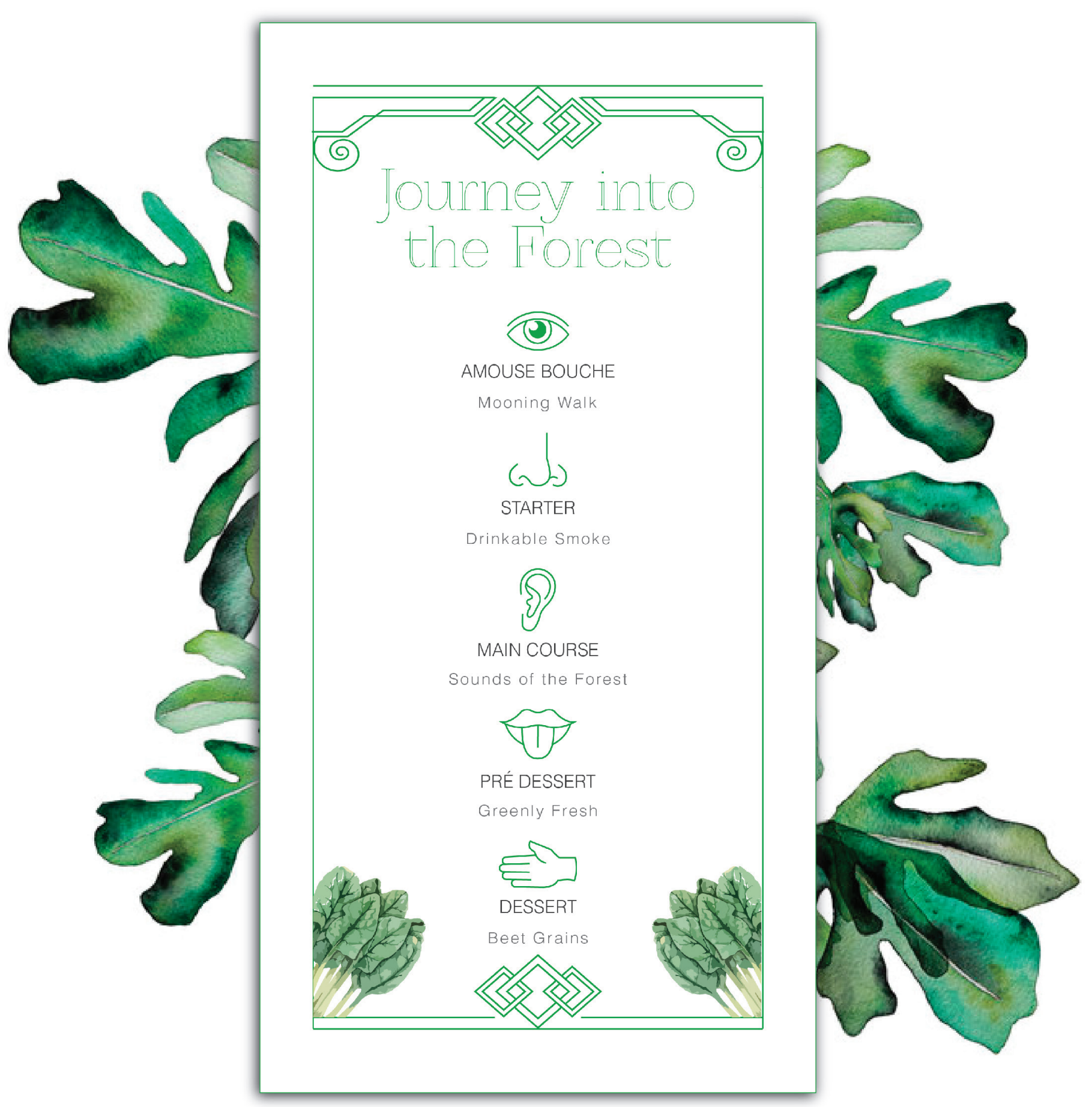




\section{ATTACHMENTS}

\subsection{RECIPE - MOONING WALK}

\section{WILD PIGEON HAIR}

1 whole pigeon

$90 \mathrm{~g}$ olive oil

$80 \mathrm{~g}$ minced onions

$100 \mathrm{~g}$ minced carrots

$7 \mathrm{~g}$ minced cloves of garlic

$80 \mathrm{~g}$ plain flour

$250 \mathrm{ml}$ dry white wine

$750 \mathrm{ml}$ organic chicken stock

$2 \mathrm{~g}$ salt

$1 \mathrm{~g}$ black pepper

$30 \mathrm{~g}$ parsley stems

1 Lt sunflower oil
Remove the feathers and clean the bird.

Bring a large pan of water to the boil. Blanch the pigeon in the boiling water for about two minutes. (This method helps to get rid it off impurities and tightens the skin.) Remove the pigeon from the pot and discard the water.

With an aid of a knife bone the pigeon.

Heat the oil in a pot over a medium heat, then saute the onion, carrot, and garlic until softened. Add the pigeon and brown for 3 to 5 minutes. Sprinkle the flour in and stir well.

Add the wine and stock, season with black and pepper, then increase the heat and bring to the boil. Lower the heat, stir in the parsley, then simmer with the lid on for 4 hours. Add an extra splash of water, if needed.

When the pigeon is nearly ready, remove the breasts from the stock and let the stock reduce to half with the remaining parts of the pigeon.

With an aid of a tweezer separate muscle filaments of the breast meat as thinly as possible, until a good amount is reached.

Heat the sunflower oil at $180^{\circ} \mathrm{C}$ and deep fried this "hair" of pigeon until it becomes dry. Remove from the oil and strain its excess.

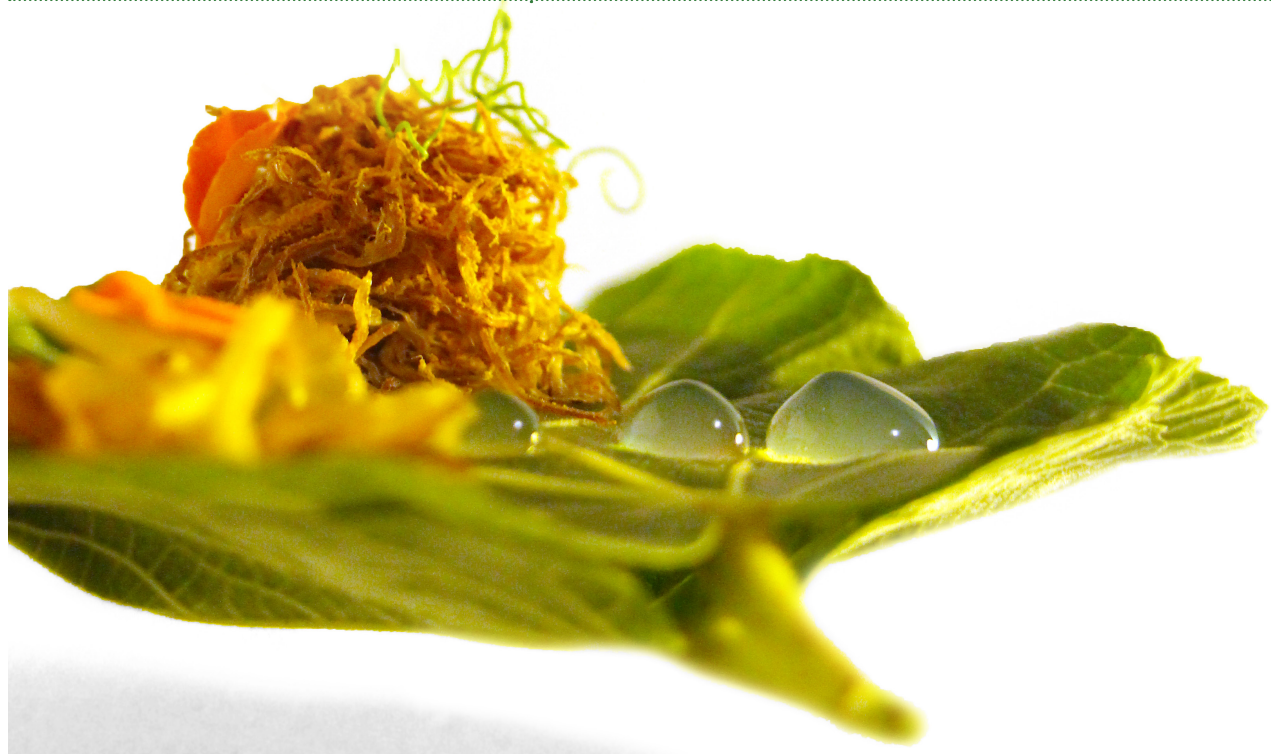

FIGURE 71. Mooning Walk under sunlight, 2018 


\section{TONIC FLUID GEL}

$500 \mathrm{~g}$ of tonic water

$8,5 \mathrm{~g}$ de low-acyl gellan

$0,4 \mathrm{~g}$ de salt

$100 \mathrm{~g}$ de sugar
Place the tonic water in a pot.

In a bowl, join the dry ingredients and stir.

Add the dry ingredients to the liquid using a whisk.

Heat until boiling or until the solid ingredients are dissolved, while whisking.

Cool down in ice. Blend and pass through a fine sieve.

\section{KATSUOBUSHI}

$500 \mathrm{ml}$ hot water

$5 \mathrm{~g}$ Glow by SOSA

$2 \mathrm{~g}$ Xanthan

$0,20 \mathrm{~g}$ Katsuobushi
Blend the 3 first ingredients and let the mixture rest.

Pour the liquid slowly to remove the powder attached to the base.

Place a small amount of this mixture while hot and place the katsuobushi flakes on top of it. Reserve.

\section{FIG'S JAM}

$400 \mathrm{~g}$ figs

300 g sugar

$150 \mathrm{~g}$ water

$150 \mathrm{~g}$ lemon juice

$2 \mathrm{~g}$ salt

1 vanilla bean, split and seeded

1 cinnamon stick
Wash, remove the stem and cut each fig into 4 pieces.

In a medium saucepan, place all ingredients and bring to a boil, until sugar dissolves, stirring occasionally.

In a low heat cook the figs, uncovered and continuing to stir occasionally, for 30-60 minutes, or until the liquid is thick and sticky.

Remove from the heat and discard the vanilla pod and cinnamon stick. Process in a food processor. Pour the jam into jars, leaving $1 / 4$ inch space and cover it. Let it cool to room temperature, then refrigerate.

Before plating stir $100 \mathrm{ml}$ of the pigeon stock together with fig's jam at room temperature.

\section{PLATING}

Pea sprouts - 1 unit

Tagete petals -3 petals

Turmeric in powder -1 sprinkle
Place the tonic water in drops format, as well as the figs jam. Garnish with the pigeon, katsuobushi flakes. Finish with sprouts, petals and sprinkle of turmeric.

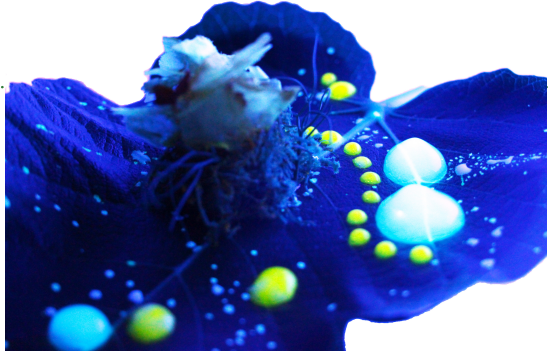

FIGURE 72. Mooning Walk under blacklight, 2018 


\subsection{RECIPE - DRINKABLE SMOKE}

\section{ROASTED CELERIAC CREAM WITH RICE MILK}

$500 \mathrm{~g}$ Celeriac

$13 \mathrm{~g}$ butter

$200 \mathrm{~g}$ rice milk

0,6 g sucro ester

(no salt at all)

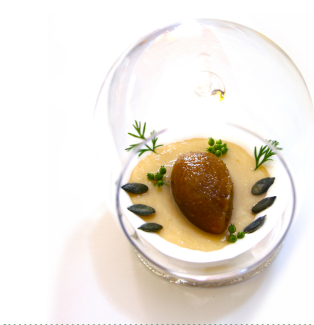

Wrap the whole celeriac, seasoned with olive oil, garlic and salt with aluminium foil. Roast it on the barbecue or in the oven with for aprox. 4 hours at $160^{\circ}$.

Peel the whole celeriac and blend it in the thermomix. Weight 285 $\mathrm{g}$ for this preparation.

Add butter, rice milk and sucro and processuntil it turns a smooth puree. Pass through a sieve.

Dilution of aroma: $1,95 \mathrm{~mL}$ of each essential oil.

\section{COCONUT MILK SMOKED WITH LAVENDER}

$200 \mathrm{ml}$ coconut milk

$30 \mathrm{~g}$ of dry lavender

$1,3 \mathrm{~g}$ of xanthan
In a large container place the milk and in another metal container burn the lavender and place inside the first container, in a way that they don't get in direct contact with each other. Cover it and let it blend the aromas for at least two hours. After smoking remove the container with the lavender ashes and reserve the milk aside.

Blend the coconut milk with the xanthan using a hand blender. Place it in a piping bag and keep it warm until serving.

\section{GRILLED APPLES JAM}

6 golden apples (to make $400 \mathrm{~g}$ of edible purée)

$50 \mathrm{~g}$ of sugar

$10 \mathrm{~g}$ of pectin $\mathrm{NH}$

$1,5 \mathrm{~g}$ citric acid
On top of hot pine coil place the apples. Turn the apples each 10 minutes until they became completely black. Let them cool.

Peel the apples. Blend the pulp.

Addthe sugar and pectin to the pulp mix until well dissolved. Boil, mixing, until the mixture reaches $105^{\circ} \mathrm{C}$. Out of the stove add the citric acid and stir.

Letthe mixture cool down in the fridge until plating.

\section{PLATING}

Coriander leaves and seeds

Pumpkin dry seeds
Pour the celeriac purée on the plate, cover with coconut milk and garnish with the apple jam.

Decorate with coriander leaves and seeds, plus the pumpkin seeds. 


\subsection{RECIPE - SOUNDS OF THE FOREST}

\section{RABBIT LOIN ROLLED IN CHARD LEAVES}

3 bio chard medium leaves

$130 \mathrm{~g}$ rabbit loin

salt

olive oil
Wash the chard leaves and cut the stalks edges.

In a steamer, cook the chard leaves for 3 minutes. After that dip it in an ice bath to stop cooking.

Roll the flat and dried leaves around the rabbit loin.

Place the previous preparation in a sous vide plastic bag. Season with a pinch of salt and olive oil.

Remove all the air with a vacuum machine and seal the bag.

Place in a pre-heated water bath at $63^{\circ} \mathrm{C}$ for approximately 1 hour, or until the middle loin temperature reaches $63^{\circ} \mathrm{C}$.

Cut using a knife and serve while still hot.

\section{EDIBLE SOIL}

$30 \mathrm{~g}$ buckwheat

$10 \mathrm{~g}$ maltodextrin

$3 \mathrm{~g}$ cacao in powder

2 g paprika,

$2 \mathrm{~g}$ activated coil

$20 \mathrm{~g}$ walnuts oil

$5 \mathrm{~g}$ truffle chopped in brunoise

salt
Cook the buckwheat In boiling water for 10 minutes., Drain and dry it well it paper towels.

In another pot deep fry the cooked buckwheat and remove the excess of oil.

In a large bowl place all the powder ingredients.

Pour the walnuts oil while stiring with a whisk. Add the buckwheat and stir.

Taste and add as many salt as needed. Reserve.

Figure 74. Sounds of the Forest, 2018

\section{FRIED BIO CABBAGE}

Cabbage leaf

Sunflower oil

Salt
Blanch the cabbage leaf for 3 minutes in salted boiling water. Drain and dry it completely with paper towels.

In a $180^{\circ} \mathrm{C}$ pre-heated oil, deep fry the leaf until bubbling stops.

Remove it from the oil and drain the excess.

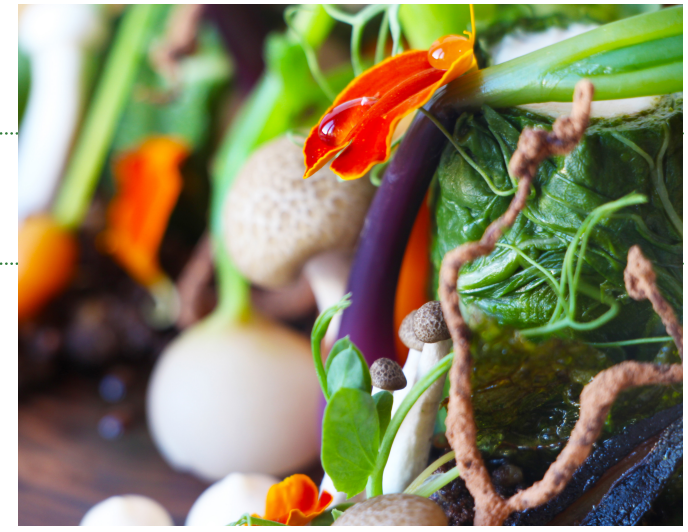




\section{BURNT ONION}

2 small bio onions

Cut the onions in half without peeling.

In a very hot fry pan place the cut side of the onions face down and let it cook until the bottom gets black on surface.

Remove from the heat and using hands separate layer by layer. Reserve

\section{BABY CARROT, BABY TURNIP, SCALLIONS}

3 Baby bio carrots
2 Baby bio turnips
2 Baby bio scallions

Salt
Wash and peeled the veggies.

In salted boiling water blanch them for 1 minute. Then cool it down inside a ice bath.

For serving heat it on the salamander for 20 seconds.

\section{PEA PROTEIN MAYONNAISE}

$5 \mathrm{~g}$ pea protein powder

$30 \mathrm{~g}$ water

65 g sunflower oil

salt

$3 \mathrm{~g}$ vanilla seeds
Hydrate the pea protein in water for 15 minutes at least.

Emulsify the oil in the previous mixture with the aid of a hand blender until become as thick as mayonese. Season with salt and add the vanilla seeds. Reserve.

\section{DEW DROPS}

200 g sugar

$200 \mathrm{~g}$ water

$100 \mathrm{~g}$ salt
In a pot add all the ingredients and let boil until everything is dissolvedand a syrup consistency achieved, or reaches $110^{\circ} \mathrm{C}$. For plating use a pasteur pipette to better control the droppings.

\section{PLATING}

\section{Green tea / matcha} powder

Mint flowers and sprouts
Place $20 \mathrm{~g}$ of granita on the base of the container. Garnish with $10 \mathrm{~g}$ of apple strips and decor with mint flowers and sprouts. In the end, sprinkle with matcha powder. 


\section{CHOCOLATE TRUNKS}

$200 \mathrm{~g}$ dark chocolate $80 \%$ cacao Callebaut

100 g cacao powder

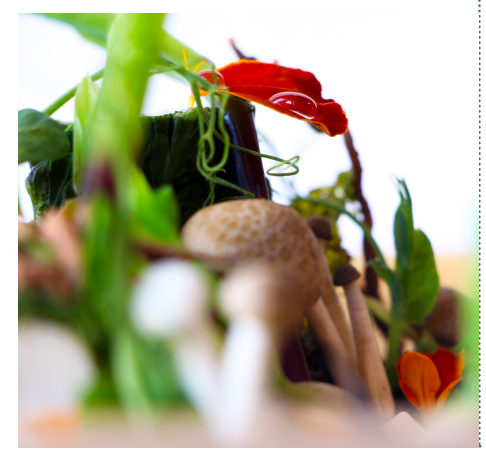

Melt the chocolate in the microwave or above a water bath until it reaches $50^{\circ} \mathrm{C}$.

Pour $3 / 4$ of the melted chocolate over a marble countertop and work the chocolate with two metal spatulas until it reaches $27^{\circ} \mathrm{C}$. Then place it again in the same bowl where the other $1 / 4$ was left, mix until becomes uniform. Check the temperature, should be $29 / 30^{\circ} \mathrm{C}$. If the temperature is not this repeat the process.

Chop ice and place flat over a container. Using small parchment paper piping bags, pipe on the ice small lines similar to organic trucks and let them get stiff.

Place cocoa powder on a plate and bread the trucks over this powder. Reserve.

FIgURE 75. Sounds of the Forest, 2018

\section{INFUSED VEIL}

$400 \mathrm{ml}$ of water

500 g oak tree soil

$10 \mathrm{~g}$ Elastic by Sosa

5 g sunflower oil
Add the soil to the water in a tempered glass container and infuse the water using an Ultrasound SONICS VCX500 by one single cycle at $100 \mathrm{hrtz}$ for 15 minutes.

Place this mixture in a round bottomed flask and attach it to the Rotavap Buchi R-300 for a low pressure evaporation, with refrigerator at $-10^{\circ} \mathrm{C}$, water bath at $55^{\circ} \mathrm{C}, 35 \mathrm{mbar}$ pressure at $100 \mathrm{rpm}$ as rotation.

With a paper towel lightly oil a flat metal tray.

Measure $250 \mathrm{~g}$ of the transparent liquid obtained and, in a pot, mix this water and Elastic. Stir with a whisk and bring to boil. Pour it immediately over the metal tray and let it set.

Cut in strips of $5 \mathrm{~cm}$ length and $15 \mathrm{~cm}$ long. Reserve.

\section{PLATING}

Pea sprouts

Tagete petals

Shimeji mushrooms

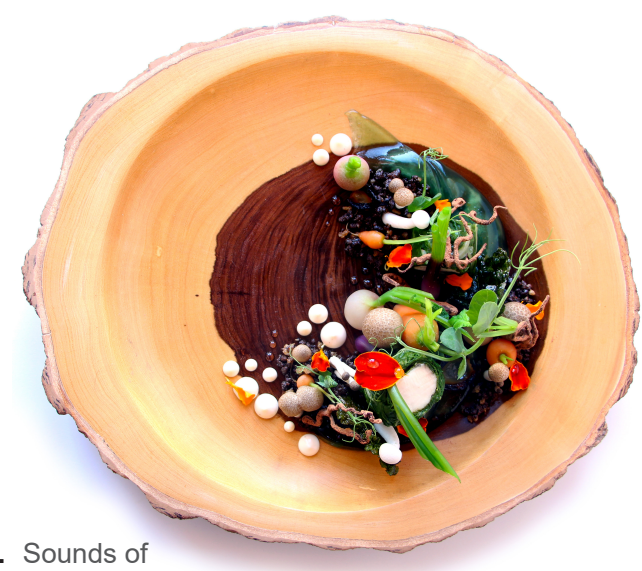

FiguRE 76. Sounds of the Forest, 2018 


\subsection{RECIPE - GREENLY FRESH}

\section{LIME AND MINT GRANITA}

$800 \mathrm{ml}$ water

$100 \mathrm{~g}$ sugar

$30 \mathrm{~g}$ mint leaves

$100 \mathrm{ml}$ lime juice

$1,5 \mathrm{~g}$ malic acid

1 drop of peppermint essential oil

$3,01 \mathrm{~g}$ xanthan $(0,3 \%$ of total weigh)

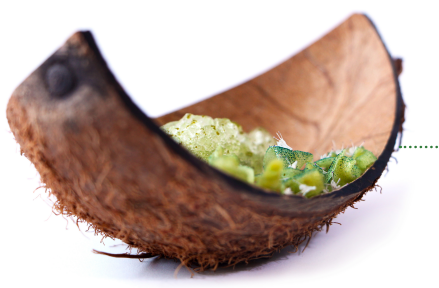

Place the water and sugar in a pot and bring to boil. Let this syrup cool to $15^{\circ} \mathrm{C}$ -

Blanch the mint leaves for 10 seconds. Remove the mint and immediately cool it in a ice bath.

Add to the syrup the mint leaves, lime juice and malic acid. Blend for 3 minutes on maximum speed.

Pass it through a fine sieve. Add the peppermint essential oil and xanthan gum and blend with the hand blender.

Place in a plastic container and freeze for one hour, then scrape the surface with two forks to break up the ice.

Return to the freezer and freeze until solid, stirring and crushing lumps with a fork every 30 minutes, until evenly frozen, 2 to 3 hours.

FIgURE 77. Greenly Fresh dish, 2018

\section{GREEN TEA IMPREGNATED APPLE STRIPS}

300 g granny smith apples

$150 \mathrm{~g}$ of green tea or matcha tonic water Schweppes

Peel the apples.

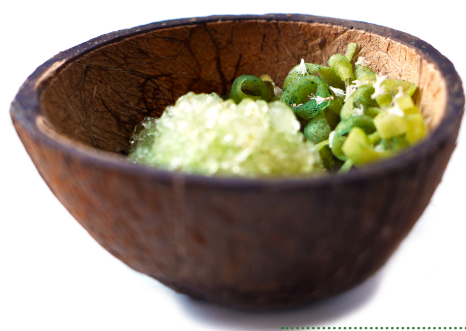

Slice the apples as thinly as possible with the help of a turning slicer. The fact of cutting mechanically allows to work with portions of very similar dimensions. Then, with a knife cut and trim the apple slices making strips of about $1,5 \mathrm{~cm}$ wide and $10 \mathrm{~cm}$ long.

Place the strips flat and organized in a vacuum plastic bag. Pour in each bag $150 \mathrm{~g}$ of the green tea at the refrigeration temperature, and then introduce into a refrigerator until reaching $5{ }^{\circ} \mathrm{C}$. This process is performed as a precaution to minimize the loss of volatiles in the vacuum chamber, since when a negative pressure is applied, the boiling point of the impregnation liquid decreases considerably.

Vacuum and seal in a vacuum machine. No need to set, can be used straight away.

Remove from the bag and place inside a siphon as along with the liquid from the bag and inject two charges of $\mathrm{CO} 2$. Keep in the fridge for at least 30 minutes.

When serving, and after releasing pressure, open the siphon and remove the apple from it .

FIgURE 78. Greenly Fresh dish, 2018 


\subsection{RECIPE - BEET GRAINS}

\section{LAVENDER ICE CREAM}

$150 \mathrm{~g}$ of dry lavender

$360 \mathrm{ml}$ skimmed milk

$60 \mathrm{ml}$ cream

$4,7 \mathrm{~g}$ gellan low acyl $(0.7 \%$ of total $)$

$35 \mathrm{~g}$ sugar

4 egg yolks

Liquid nitrogen
Make a cold infusion of the dried lavender in the milk, let it rest for 24 hours in the fridge.

Boil the milk and the cream. Add the gellan and blend using a hand mixer.

Wisk the sugar with the egg yolks until foaming.

Pour a little of the milk mixture in the yolk mixture, mix very well. Then pour the rest over low heat until it reaches the maximum of $73^{\circ} \mathrm{C}$.

Add liquid nitrogen always mixing, until you get the desired consistency for the ice cream.

Notes:

1 - If the lavender is fresh, dry it in the dehydrator at $45^{\circ} \mathrm{C}$ for 48 hours.

2 - An ice-cream machine can be used instead the liquid nitrogen.

\section{BEET FLUID GEL}

$200 \mathrm{~g}$ beet juice

$50 \mathrm{~g}$ balsamic vinegar

$2.5 \mathrm{~g}$ gellan low acyl

$2.5 \mathrm{~g}$ salt

$0.25 \mathrm{~g}$ xanthan

Ice
Put the juice and the vinegar in a pot.

In a bowl, join the dry ingredients.

Add the dry ingredients to the liquids using a wisk.

Heat until boiling or until the solid ingredients are dissolved.

Cool down in ice.

Blend and pass through a fine sieve.

\section{LEMON MOUSSE}

$3 \mathrm{~g}$ gelatin sheets

$100 \mathrm{~g}$ cream with $20 \%$ lemon juice

$0.25 \mathrm{~g}$ xanthan

2 siphon N2O (cream) cartridges
Soak gelatin sheets in cold water for 5 to 10 minutes to soften

Heat the cream to $55^{\circ} \mathrm{C}$.

Squeeze out the excess moisture from the gelatine, then add to the warm cream and stir until dissolved. Join xanthan and blend with the hand blender.

Place in the siphon with $2 \mathrm{~N} 2 \mathrm{O}$ (cream) charges. Shake and reserve in the fridge. 


\section{AERATED MACARON}

$120 \mathrm{~g}$ beet juice

$24 \mathrm{~g}$ isomalt

$15 \mathrm{~g}$ albumin powder

$10 \mathrm{~g}$ methylcellulose

$1,2 \mathrm{~g}$ ascorbic acid

$1 \mathrm{~g}$ salt
Bring the juice to simmer and remove from heat. Skim the top. Let to cool to home temperature.

Blend isomalt, albumin, methylcellulose and ascorbic acid into cooled juice.

Season with salt and refrigerate for $12 \mathrm{~h}$ to hydrate the dry ingredients.

Whip the hydrated meringue base until stiff.

Pipe meringue into half spheres molds.

Dehydrate in $90^{\circ} \mathrm{C}$ for 4 hours.

Reserve in a cool and dry place.

VEIL

$12 \mathrm{~g}$ elastic by Sosa

$200 \mathrm{~g}$ beet juice

200 g syrup TPT
Dissolve elastic in the cold beet cold juice and mix with a wisk to hydrate. Add the syrup.

Bring the mixture to boil and poor immediately on flat surface to get the minimum thickness possible.

\section{ORANGE GELATIN BLOCK} juice

$500 \mathrm{ml}$ fresh orange

10 mint leaves

3 gelatine sheets
Heat orange juice and add sugar if necessary. Out of the fire and mint and let infuse for $1 \mathrm{~h}$, covered by film.

Soak gelatin sheets in cold water for 5 to 10 minutes to soften.

Remove the mint frm the orange juice and warm it again until $55^{\circ} \mathrm{C}$.

Squeeze out the excess moisture from the gelatine, then add to the warm juice and stir until dissolved.

Pour over a square plastic box quilted with film, $4 \mathrm{~cm}$ high.

Mature for 18 hours in the fridge. Cut in desired shapes. 


\section{CINNAMON FOAM}

$100 \mathrm{~g}$ beet juice

$3 \mathrm{~g}$ sucroemul by Sosa

$6 \mathrm{~g}$ cinnamon sticks
Make a cold infusion with all the ingredients for 12 hours, including the sucroemul, to allows it to hydrate.

Pass through a sieve.

Make a foam with the hand blender or aquarium pump

After the foam is created, let it rest 2 minutes.

With a spoon remove the top part and use it.

\section{BEET MICROWAVE SPONGE CAKE}

$50 \mathrm{~g}$ of almond powder

$100 \mathrm{~g}$ cooked beet

$125 \mathrm{~g}$ egg whites

$80 \mathrm{~g}$ of yolks

50 g sugar

$65 \mathrm{~g}$ flour

$12 \mathrm{~g}$ beet reduction or beet colouring by sosa

2 siphon $\mathrm{N} 2 \mathrm{O}$ (cream) cartridges
Blend all the ingredients, pass through the sieve and put in a siphon charged with 2 N20 cartridges. Refrigerate for a few hours.

Fill $1 / 2$ of the plastic cups, pierced in the bottom.

Cook for 35 seconds in microwave and place the cups face down to keep moisture.

When is cold, unmold it using a scissor.

Note: The beet reduction is obtain by simmering in low heat the beet juice until it's thick and concentrated.

\section{CITRUS CURD}

$180 \mathrm{~g}$ eggs

$100 \mathrm{~g}$ white sugar

$50 \mathrm{~g}$ lemon juice

$50 \mathrm{~g}$ lime juice

$100 \mathrm{~g}$ orange juice

$25 \mathrm{~g}$ full fat milk

$12 \mathrm{~g}$ lime zest

$134 \mathrm{~g}$ butter, softened

$6 \mathrm{~g}$ of beet colourant

1 sheet of gelatin
Mix the eggs with the sugar and pass through a sieve.

Add the juices, milk and zest. Incorporate everything.

Cook in a vacuum bag in sous vide for 30 minutes at $78^{\circ} \mathrm{C}$ and turn the bag every 10 minute.

Pass through a fine sieve after cooking.

when the temperature is $40^{\circ} \mathrm{C}$ add the butter and emulsify with the hand blender.

Soak the gelatin in cold water, drain and remove the excess water and melt in the microwave.

Add a gelatin and the colourant mixing.

Place the curd in the fridge at $4^{\circ} \mathrm{C}$. 
HONEY MOUSSE AND MINT

$50 \mathrm{~g}$ english curd

33 g honey

1 sheet of gelatin

$67 \mathrm{~g}$ whipped cream

$200 \mathrm{~g}$ fresh mint

$50 \mathrm{~g}$ mascarpone

For english curd:

$125 \mathrm{ml}$ milk

$1 / 2$ vanilla bean

1 egg yolk

$15 \mathrm{~g}$ caster sugar
Preparation of the english curd

Boil the milk with the vanilla splited in half, in medium heat.

when the milk starts boiling take out from the heat and let infuse for 5 minutes.

Wisk the yolk with the sugar until ribbon stage.

Pour a little of milk on the eggs and mix. Pour the rest and mix. Place back on the heat and mix continuously without letting the mixture boil. Use a thermometer to make sure it does not pass the $75^{\circ} \mathrm{C}$.

Mix until has the sauce consistence. Pass thought a sieve and let cool down in the fridge covered with cling film, that should be in contact with the cream.

Preparation of the honey mousse:

Make a cold infusion of 24 hours only with the mint and the cream, in the fridge. Pass through a sieve to remove all the mint leaves.

Heat the english curd, honey and pre-soaked and squeezed gelatin, in a pot.

Incorporate the mascarpone, at room temperature. Add, involving, the whipped cream.

Pour over a square plastic box quilted with film, $4 \mathrm{~cm}$ high.

Allow to solidify in the freezer.

\section{SUGAR CASTLE}

24 g egg white

$32 \mathrm{~g}$ sugar

Beet colourant
Whip in the fix mixer for 30 minutes the egg white with sugar, to make sure that every sugar crystal is hydrated by egg white.

Add the colourant only in the end.

Put in piping bags and make little dots on the silpat.

Place in the dehydrator at least for 3 hours at $50^{\circ} \mathrm{C}$, keep them on the dehydrator until use or place in a closed hermetic box with silica gel. 


\section{ISOMALT CANNELLONI}

$100 \mathrm{~g}$ isomalt

Obulato leaves

Colourant powder or powdered dry beet
Sprinkle with a sieve the isomalt on obulato leaves. Add the colourant or beet powder on the top.

Bake in the oven at $180^{\circ} \mathrm{C}$ for 5 minutes, turn the tray during the baking.

When is still hot shape them in a cannelloni shape with a tube.

\section{CRUMBLE}

$110 \mathrm{~g}$ butter

$210 \mathrm{~g}$ flour

$170 \mathrm{~g}$ sugar juice

$60 \mathrm{~g}$ ginger zest and

$20 \mathrm{~g}$ cinnamon

$30 \mathrm{~g}$ beet juice
Mix all the ingredients, but don't work the gluten, just the enough to homogenize.

Place on a tray and bake in the oven at $160^{\circ} \mathrm{C}$ for half a hour.

After removing from the oven, let cool down and grind a little with your hands.

\section{BEET CHIPS}

1 red beet

Oil

Icing Sugar

Powdered dried beet
Wash and cut the beet with a mandolin. Wash again, dry and fry, drain the oil.

Blend the sugar and the dehydrated beets, pass through a sieve and bread the chips with this powder.

Note: To make the dried beet in powder, dehydrate sliced beet in the excalibur for 3 days at $50^{\circ} \mathrm{C}$. Then blend that in the thermomix.

\section{DARK CHOCOLATE GANACHE}

$100 \mathrm{~g}$ dark chocolate

$50 \mathrm{~g}$ beet juice

$5 \mathrm{~g}$ ginger juice

$30 \mathrm{~g}$ invert sugar

Figure 79. Beet

Grains dish, 2018
Chop the chocolate and put it in a bowl. Boil the liquids (juices and sugar) and pour over the chocolate. Stir to homogenize everything without incorporating much air.

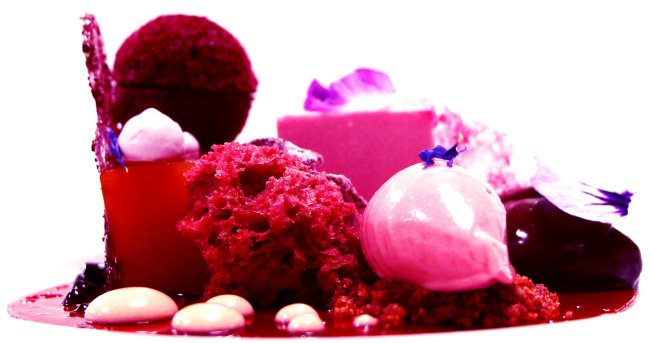




\subsection{FORMULARIO DE ANÁLISIS SENSORIAL}

Formulario de Análisis Sensorial

Este estudio se centra en una análisis sensorial de la crema de apio en differentes platos.

Beba agua entre las muestras para limpiar su paladar y huela su muñeca para neutralizar los aromas. Evite inspiraciones largas para no cansar el olfato.

Por favor rellene los siguientes 3 tipos de pruebas / clasificaciones que tomarán arededor de 15 minutos para ser hecho. Sea honrado respondiendo y gracias por su tiempo.

Sexo: M/F Edad:

¿Has fumado o masticado una goma de menta en los últimos 30 minutos? Si /

¿Comiste algo en los últimos 30 minutos? Si / no

En caso afirmativo, describa lo que fue:

Tipos de aromas

Huele y pruebe los tres platos frente a usted de izquierda a derecha, marque con una (X) sólo 2 caracteristicas aromáticas que describen más bien cada plato.

Código del plato:

\begin{tabular}{|l|l|l|l|l|}
\hline Caramelo & Tierra & Dulce & Humado & Frutas secas \\
\hline
\end{tabular}

\begin{tabular}{|l|l|l|l|l|}
\hline Herbáceo & Vegetal & Picante & Acre & Quemado \\
\hline
\end{tabular}

\begin{tabular}{|l|l|l|l|l|}
\hline Fermentado & Floral & Fruta & Mantequilla & Agrios \\
\hline Asado & Avellanado & Químico & Leñoso & Rancio \\
\cline { 2 - 3 } & &
\end{tabular}

Código del plato:

\begin{tabular}{|l|l|l|l|l|}
\hline Caramelo & Tierra & Dulce & Humado & Frutas secas \\
\hline
\end{tabular}

\begin{tabular}{|l|l|l|l|l|}
\hline Herbáceo & Vegetal & Picante & Acre & Quemado \\
\hline
\end{tabular}

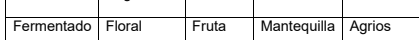

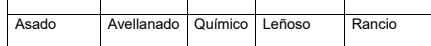

Código del plato:

\begin{tabular}{|l|l|l|l|l|}
\hline Caramelo & Tierra & Dulce & Humado & Frutas secas \\
\hline
\end{tabular}

\begin{tabular}{|l|l|l|l|l|}
\hline Herbáceo & Vegetal & Picante & Acre & Quemado \\
\hline
\end{tabular}

\begin{tabular}{|l|l|l|l|l|} 
& & & & \\
\hline Fermentado & Floral & Fruta & Mantequilla & Agrios \\
\hline
\end{tabular}

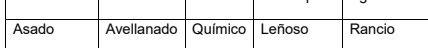

Prueba de Ordenación

Huele los tres platos todos a la misma distancia, de izquierda a derecha.

Clasificar las muestras en orden de intensidad de aumento del olor.

10: ___ (el más ligero)

$2^{0}:$

30: $\quad$ (el más fuerte)

Ahora, siguiendo el mismo orden, pruebe con una cuchara cada uno de los platos y chasifiue las muestras en orden de intensidad de aroma creciente.

$1^{10}$ ___ (el más ligero)

$2^{0}:$

30: (el más fuerte)

Por último, siguiendo el mismo orden, beber un sorbo y clasifica las muestras según su intensidad de aroma

$1^{0:}$ ___ (el más ligero)

$2^{0}:$

$3^{0}: \quad$ (el más fuerte)
Prueba de escala

Evalúa el aroma de cada muestra, de izquierda a derecha, y marcar en la escala la

Código del plato:

Jengibre

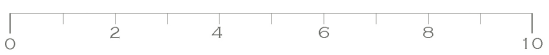

Mandarina verde

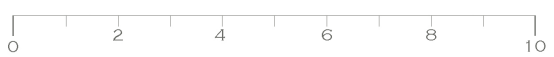

Código del plato:

Jengibre

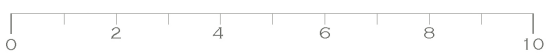

Mandarina verde

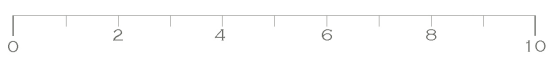

Código del plato:

Jengibre

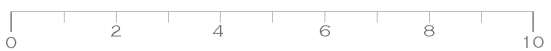

Mandarina verde

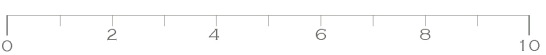




\subsection{PAPPER SUBMITED CRC LAYOUT}

Designing for the senses through food design and psychophysiology

R. Mota \& P. Mata

LAQV, REQUIMTE, Departamento de Quimica, Faculdade de Ciências e Tecnologia/Universidade Nova de Lisbod,

2829-516 Caparica, Portugal

H. Vilaseca

La Masia (I+R) del Restaurante El Celler de Can Roca, Calle Can Sunyer 48, 17007 Girona, España

R. Bonacho

Centro de Investigação em Arquitetura, Urbanismo e Design, Faculdade de Arquitetura da Universidade de Lisboc

M. Carvalho

ABSTRACT: Olfactory perception of food can be dramatically affected by the way it is presented and particuprocess, a design of the containers. The aim of the present study was to develop a container, using desig process, a literature review, and research based on psychophysiology, in order to optimize the sensory percep-
tion of the food served and improve the global experience. The work described in this paper is part of a more
comprehensive investigation for the development of a tasting menu composed by five dishes, each one of these tending mainly to stimulate a particular sense.

The development of the containers, the food used for the research and the sensory analysis was done at La way the food is eaten, had an impact on the perception of this dish particularly on the perception of aromas and smells

Keywords: Food-Design, Psychophysiology, Gastrophysics, Sensory Perception, Ergonomics

1 INTRODUCTION

Design and Gastronomy are parallel universes both involving a conception and an execution of an id would be much more difficult and meding ourselves man creativity and Design have always sought to inprove the feeding process, providing tools to obtain food, to eat and to cook. In the course of human evolution, Design eventually gave rise to tools and prcedures in more or less elaborate preparations an functionality, acquired symbolism and representas (Capella 2015).

Even the simplest meal is a complex composition of textures, colours, shapes, tastes, aromas, flavou odyssey causing various senstions in people. Food is odyssey caing various sensations in people. Food is in order to improve their sensory characteristics. This new emerging territory of Design, known as Food D sign, intends in this research to serve our senses. ers, scientists, etc., as this interdisciplinary holis approach, and the sharing of different knowledge, low the achievement of better results (Hermannsdó et al. 2012). "The Five Aspects Meal Model" by
Gustafsson et al. (2006) is the practical example of Gustafsson et al. (2006) is the practical example
this. The concept of Eating Design by covers and con

to order by the intensity of smell/aroma samples, perceived in three different situations: sniffing witho tasting, eating using a silver spoon and drinking a sip; 2) tasters were asked to pick from 20 aromatic char-
acteristics the two that better described each dish; 3 ) acteristics the two that better described each dish;
tasters should apply a structured numeric scale te ing essential oils intensity.

2.5 Data analysis

In order to detect if the design of the containers had significant impact on the perception of this dish, particularly in the perception of aroma and smell, a non-
parametric analysis (Friedman) was performed. parametric analysis (Friedman) was performed
Whenever the results revealed significant differences, Whenever the results revealed significant differences
the Multi Mean Comparisons were made using Wilcoxon Signed-Rank test to identify that differences For the second test the principal component analysis
(PCA) method was used to identify the most relevant (PCA) method was used to identify the most relevan
characteristics of each dish. Differences were considcharacteristics of each dish. Differences were consid-
ered significant when $\mathrm{p} \leq 0,05$. Statistical analyses 24 and XLStat.

3 RESULTS

Considering the ranking test, the intensity of aroma some samples: in the glass and bowl the smell per-
ceived by sniffing was perceived as significantly more intense than in the bottle $(\mathrm{M}=2.27$ and $2.18 \mathrm{v}$ $1.55, \mathrm{p} \leq 0.05)$; the aroma perceived when drinking
sip was more intense in the glass in opposition to the sip was more intense in the glass in opposition to
bowl or bottle $(\mathrm{M}=2.45 \mathrm{vs} .1 .71 \quad 1.83$, $\mathrm{p} \leq 0.05)$; an when using a spoon the differences did not reach significance $(\mathrm{M}=2.00$ for the glass, 1.94 for the bottle, 2.06 for the bowl, $\mathrm{p} \geq 0.05$ ) as the interaction plot Figure 2 i

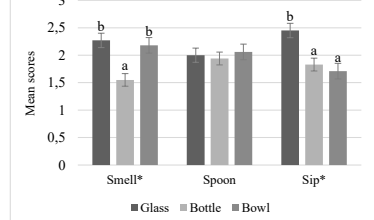

Figure 2 - Mean scores of the perceived intensities of smell by sniffing,
and of aroma by tasting using a spoon and drinking a sip.
Note: For similar characters the ranks are similar, for a $5 \leq 0.05$. * identote. For similar characters the ranks are simlar, tor a $\mathrm{p} \leq 0.05$. * iden-
tifies significant differences as measured with Tukey's and Wilcoxon,
p $\leq 0.05$. (Zampollo 2013).

an (1856-1924) 2008). Tasting a dish is not only a flavour experience but involves also an additional vivid sensory experience of shape in mind's eye, or perhaps "feel he shape in mind's hand instead, speaking of

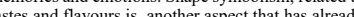
been studied (Spence \& Deroy 2013). Previous experiences may also induce expectations and can influchic fore symbolism can therefore be seen as a spe-

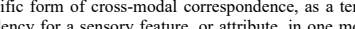
dality, either physically presented or merely magined, to be matched (or associated) with a sensory feature in another sensory modality. Recent stucies have been published about some cross-modal corespondences for instance, matching tastes, aromas,
and flavours with colours (Spence et al. 2012), sounds (Piesse 1891, Hansen 1968, Rudmin \& Cappelli 1983, Mesz et al. 2011, Crisinel \& Spence 2012, Knöferle \& Spence 2012, Deroy et al. 2013) and shapes (Deroy \& Spence 2013, Stewart \& Goss
2013). Also familiarity is associated with pleasant2013). Also familiarity is associated with
ness in odour detection (Liang et al. 2013) Since food can be considered a pleasure, a disease a fuel humans and animals empirically smell food

For the second test, the aromatic characterization of the dish served in each container, the Friedman
analysis shows that there is a significant difference of $\mathrm{p}=0.043$ among the features. This statistical significant difference was specified by Wilcoxon analysis. and bowl (M=1.62 vs. $2.312 .07 \mathrm{p} \leq 0.05$ ).
and With PCA a biplot chart was obtained (Fig. 3) that reveals which features were the most significant ones
correlated to each container. The bowl is associated correlated to each container. The bowl is associated
to Vegetala ${ }^{a}$, Herbaceous

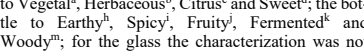
coherent, consequently it is not significant, however
the profile graph (Fig. 4) shows that it is related to Citrus ${ }^{c}$, Floral ${ }^{\mathrm{B}}$ and Smoky'.

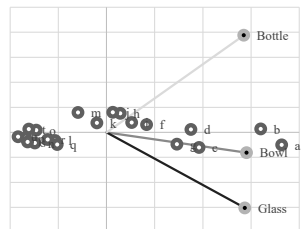

Figure 3- Biplot (axis $\mathrm{F} 1$ and $\mathrm{F} 2: 95.39 \%$ ) made as a result of $\mathrm{PCA}$

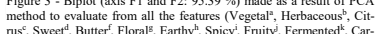

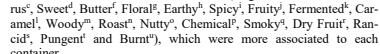

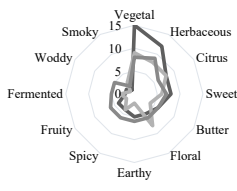

Figure 4- Profile spider chart reckoning in positives counting of the
relevant aromatic characteristics for the three containers, related to the

About the structured numeric scale test, contrafy About the structured numeric scale test, contrary
to expectations, the impact of the presentation of dish in containers with different designs and characeristics did not reach significance $(p \geq 0.05)$ in term participant's perceptions of the aromas added by
rreen mandarin and ginger essential oils. This means green mandarin and ginger essential oils. This means
that, in this study, their aromatic intensity did not de-
pend on the containers used. action, technique, nature, culture and society is (Wject shoul the the ence taste perception (Shankar et al. 2010).

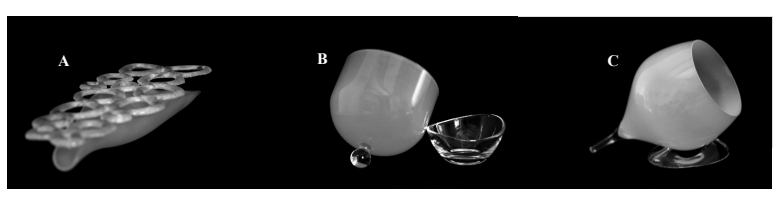

(externally) before placing it in the mouth (Garner
1974, Rozin 1982). The sense of smell is the ability to detect vaporized chemical molecules (usually of
low molecular mass) (Guyton \& Hall 2006). Between 75 and $95 \%$ of what is commonly considered as flavour really relies on the information transduced by the nose (Gibson 1966 , Stevenson 2009 , Spence
2015). Specifically about the sense of smell there is still much to be studied, "the number of discriminable
smells may be much closer to one trillion"(Briggs tors in the olfactory epithelium is a property of the person perceiving it and not of the molecules being
perceived (Sell 2014). Individual variations in the odour detection threshold, intensity and character,
linked to genetic variations have been reported (Ulloa linked to g

Apart from the smell of the food, extra olfactory elements can be used to change or enhance perception
of food as: atomizers used to spray over the meal o even over the customer, smoke-filled containers, air-
filled pillows with aromas, organic elements like leaves or wooden cutlery, Aromafork $\mathbb{R}$, porous ceramic spoons that release aromas, dry ice and liquid nitrogen diffusion, Vaportini®, rotary evaporators,
etc, (Spence \& Youssef 2015, Spence 2017). It is also etc, (Spence \& Youssef 2015, Spence 2017). It is also
important to understand how aromas behave and are perceived in containers with different designs, in order to efficiently take advance of the olfactory sys-

2 MATERIALS AND METHODS

2.1 Food stimulus

A roasted celery cream was prepared using, for a total amount of $3 \mathrm{~kg}, 1707 \mathrm{~g}$ of roasted and peeled celery
root, $75 \mathrm{~g}$ of salty Président $\circledast$ butter, $1215 \mathrm{~g}$ of rice milk by Vive Soy®, $3 \mathrm{~g}$ of sucroester by Texturas $1,95 \mathrm{~mL}$ of each green mandarin and ginger essential
pure oils by Organic Skin Food $\mathbb{R}$. The cream was divided in individual ninety grams portion stored in sous vide bags and then frozen at $-17^{\circ} \mathrm{C}$.
This food stimulus was chosen since this root is very aromatic, eco-friendly, nutritious and cheap.
Celery root also showed a good flavour matching

dish in containers with different designs and characteristics has a significant impact on the perception of
the dish, particularly in the perception of aroma an

smell.
The results show that tasters' olfactory perception changed significantly. In general, the best containe to enhance the smell and aroma of the roasted celery
cream was the glass in the sniffing and sipping trials. It is well known that the impact of glassware is i portant when tasting wine. There are some scientific Wan et al. 2015) about how the physical parameter
of a glass: size, shape and opening influence wine of a glass: size, shape and opening influence wine
tasting. A glassware with a more closed opening cotasting. A glasswaro wites wine aromas ing the nose towards the centre of the glass, distinpotential (Spence \& Wan 2015). This can also justify our results.

When using a spoon, no significant difference in
and sumed that the cutlery cuts the link between the cotainer characteristics and human physiological perception, equalizing and limiting sensory perception
This can also be the explanation for the fact that away from restaurants everyone prefers to eat roaste

bottle was the less intense, the organic shape appear-
ance and the lid with holes did not prevent the foo from being totally exposed to the exterior atmos-
phere, resulting in a faster cooling down of the cream during tasting. Lower temperatures reduce odour and
flavour intensities (Ventanas et al. 2010). Also les steam is available and so a smaller amount of airborn odorants are released and reach the cilia in order to \& Guyton 2006, Guichard et al. 2017). For the bowl, the smell intensity perceived by
sniffing was similar to the glass, however the aroma intensity perceived by sipping was the less intense.
This can be related to the cloche cover. For the the volatiles were concentrated in the cloche head-
sace. For the sipping the cloche was kept away, the space. For the sipping the cloche was kept away, the
bowl was then without the headspace concentrated bowl was then without the headspace concentrated
odorants. Spence $(2015)$ showed that this happene with coffee, once it is smelled for the first time after strong again.
The reason for the material chosen for all the containers to be fizzy transparent recycled glass, apart from the Roca Recicla $\mathbb{R}$ sustainability brand image, tics reduce the impact on the other senses, thus allow- with ginger and green mandarin essential oils, sever
tests were made to define the right concentrations. 2.2 Containers

Three different containers (fig. 1) made with fizzy transparent glass were created from recycled glass at de Can Roca Restaurant. One was a used half transparent fizzy bottle, covered with a lid with an organic
shape made from a Siemens $\mathbb{R}$ glass oven with irregular holes made from bottlenecks. Another a common transparent bowl covered with a fizzy glass campan-
ula. The third container was a recovered broken bal-
loon glass, with a fizzy inside obtained using a Palliloon glass, with a fizzy inside
natrici Norblast $\mathbb{R}$ machine.

2.3 Participants

Participants were thirty-three volunteers, without any food intolerances, allergies or taste and smell reCan Roca Girona. This group of tasters was composed by 18 males and 15 females. aged between 19 and 56 (mean 29,5 years, standard deviation 9,8 years). Although these were non-trained tasters, they can be considered experts as they work in the restau-
rant and are familiar with food tasting and ingredi24 Procedure

Participants were asked to restrain from eating for at Participants were asked to restrain from eating for at
least half an hour before the tasting. The tasting was done in a room, away from the production zone, with a temperature of $24^{\circ} \mathrm{C}$. Natural mineral water was
available for mouth cleaning between samples. The roasted celery cream samples $(90 \mathrm{~g}$ ) were warmed in three continers. The food was plated 20 seconds before tasting.
According to Macfie \& Bratchell (1989) a random According to Macfie \& Bratchell (1989) a random
tasting order was established for the containers. A tasting order was established for the containers. A
quick introduction was made to each taster and they
were not informed that the samples were identical. Three tests were sequentially performed 1) a ranking
test ISO 8587:2006 (ISO 2006), in which tasters had

containers and the lids reduces the taster's previous expectations. iance of aromatic characteristics obtained in the sec-
ond test. The bottle, the container that has the most organic shape, as the base seems a bamboo leave and
the lid looks like stones, is associated with earthy,
spicy, fruity, fermented and woody aromas. A sensaspicy, fruity, fermented and woody aromas. A sensa-
tion transference might have occurred and the attributes of the container influenced the rated attributes of
the food (Piqueras et al . 2012) Also the bottle cooling rate is higher when compared to the other contain-
ers, thus the amount of odorants released is smaller ers, thus the amount of odorants released is smaller
and the association to the attributes of the container can be more relevant. The bowl was evaluated as vegetal, herbaceous, citrus and sweet. The shape of the shapes enhance the sweet sensitivity. In fact, the glass looks round as well, although its sharp end breaks the totally roundness, so it reduces the impact (Bar \&
Neta 2006, Deroy \& Valentin, 2011, Liang et al. 2013, Ngo et al. 2013). The citrus features were associated equally to the bowl and the glass. It has been shown that various citrus components present in
green mandarin essential oil (Organic Skin Food $₫$ ) green mandarin essential oil (Organic Skin Food $\mathbb{R}$
producer and seller stated containing 70,44\% of limproducer and seller stated containing $70,44 \%$ of lim-
onene analysed by gas chromatography-mass spectrometry at $20^{\circ} \mathrm{C}$, by HP 5890 ), can reduce the odour perception of others components (Spence 2014). The results of the last test were not significant, this can be explained by the fact that the sensory percep-
tion can change with repetitive tasting of the same food, and can either decresse, due to satiety, boredom or irritation, or increase, due to increased familiarity and/or a change in perceived complexity, which in turn can impact on perception (Appelqvist et al. 2016). Most sensory perception reto avoid olfactory adaptation, and the tests should be discontinuous or with some resting periods to allow
nerves recover from their refractory state (Moncrieff 1956). Further research should be carried out in order to ducing the amount of aromas, and designing a shorter
sensory test. Also, future studies should involve a sensory test. Also, future studies should involve a
larger number of tasters in order to find more robust differences.

\section{CONCLUSION}

According to Spence (2014) making chefs and culinary artists aware of the power of smell will make experience design.

Our findings suggest that different designs of con-
tainers, as well as the process used to eat, can modify 
the aroma and smell perception. The container with the glass shape was identified as the best for enhancing the olfactory perception of the dis.

This type of pounge can be relevant in the deducers. Contacts have been made with Vista Alegre for the development of a new container for food based on the results of this study. However, there is still room for further thisestigation regarding the charateristics of the perfect plate to enhance the aroma pe-
ception. Design promotes possibilities, approaches and competencies required, for this kind of projects and, if needed, to allow results to be reformulated, sharpened, redefined and reframed. (Schiffersten The

There is an increasing need for multidisciplinary volved in flavour perception.

6 REFERENCES

Adhikari, K.; Hein, K.A.;; Elmore, J.R.; Heymann, H.; Willot, Alikari, K.; Hein, K.A.; Elmore, J.R.; Heymann, H.; Willo
A.M. 2006. " "lavor Threshold as Affected by nnteration
among Three Dairy-Related Flavor Compounds." Journal among Three Dairy-Related Flavor Compounds." Journal
Sensory Studies 21(6):626-643 Appelquist, I.A.M.;.; Poelman, A.A.M.; Cochet-Broch, M. Delahunty, C.M. 2016. "Impact of Model Fat Emulsions on
Sensory Perception Using Repeated Spoon to Spoor Ingestion." Physiology a umans Prefer Curved Visua Objects." Psychological Science 17(8):645-648. Briggs, H. 2014. "Nose Can Detect One Trillion Odours." $B B C$
News Online. Retrieved (htpp///www.bbc.com/news hhealth26638085). Reriond (his

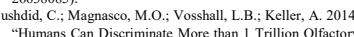
"Humans Can Discriminate More than 1 Trillion Offactory
Stimuli." Science 343:1370-1372. Capella, J. 2015. Tapas - Spanish Design for Food. Barcelon Capella, J. 2015. Tapas - Spanish Design for Food. Barcelona.
Sociedad Estatal de Acción Cultural, SA. Sulture. London, UK.
Catterall, C. 1999. Food: Design and Cullute Lon Laurence King. (a)

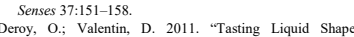
Deroy, O.; Valentin, D. 2011. "Tasting Liquid Shape
Investigating the Sensory Basis of Cross-Moda Correspondences." Chemosensory Perception 4(3):80-90. Correspondences. "Chemosensory Perception $4(3): 80-90$
Deroy, O.; Crisine, A-S.; Spence, C. 2013. "Crossmodal
Correspondences between Odors and Contingent Features. Correspondences between Odors and Contingent Features
Odors, Musical Notes, and Geometrical Shapes: Odors, Musical Notes, and Geometrical
Pychonomic Bulletin \& Review 20(5):878-896. Garner, W.R. 1974. The Processing of Information and
Structure. $6^{\mathrm{th}}$ ed. New York: Potomac, L. Erlbaum Structure.
Associates. bson, J. J. 1966. The Senses Considered as Percept Systems. Boston: Houghton Miffli

Guichard, E.; Salles, C.; Morzel, M.; Le Bon, A-M. 2017.
Flavour: From Food to Perception. $1^{1 *}$ ed. UK: John Wiley

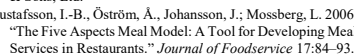

Guyton, A.C; Hall, J.E; 2006. Textbook of Medical Physiology.
$11^{\text {thb }}$ ed. Philadelphia, PA, USA: Elsevier's Health "What's Cooking? Designing to Change Food-Related . CltHansen. K. 1968. "Taste and Pitch." Perceptual and Motor Skills 27:59-68. Holt-Hansen, K. 1976. "Extraordinary Experiences during
Cross-Modal Perception." Percepprual and Motor Skills Cross-Modal Perception." Perceptual and Motor skill
43:1023-1027. ummel, T.; Delwiche, J.F.; Schmidt, C.; Hüttenbrink, K.B. 2003. "Effects of the Form of Glasses on the Perception of 41(2):197-202. A

ISO $4121: 2003$. "Sensory Analysis - Guidelines for the Use of
Quantitative Response Scales." $2^{\text {nd }}$ ed. Switzerland:

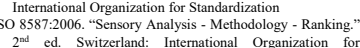

Standardization
Knoforle, K.M.; Spence, C. 2012. "Crossmodal
Cores Correspondences between
Psychonomic Bunds and atin \& Review 19:992-1006. Liang, P.; Roy, S.; Chen, M.L.; Zhang, G.H. 2013. "Visual Influence or Shapes and Semantic Familiarity on Humar

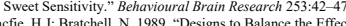
of Order of Presentation and First-Order Carry-Over Effects in Hall Tests." Journal of Sensory Studies 4:1229-148.

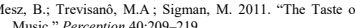
Music." Perception 40:209-219.
oncrieff, R.W. 1956. "Olfactory

Likeness." Journal of Physiogory $133.301-316$ and Odour go, M.K.; Velasco, C;; Salgado, A.; Boehm, E;; O'Neill, D. Spence, C. 2013 . "Assessing Crossmodal Correspondences
in Exotic Fruit Juices: The Case of Shape and Sound Symbolism." Food Quality and Preference 28(1):361-369. Cousen Spence C. 2012. Audiovisual Crossmodal Press.
Piesse, G.W.S. 1891. Piesse's the Art of Perfumery. $5^{\text {th }}$ ed. nce, C. 2012 queras-Fiszman, B; Alcaide, J., Roura, E.; Spence, C. . 2012
"Is It the Plate or Is It the Food? Assessing the Influence of
the Color ( Black or White) and Shape of the Plate on the the Color ( Black or White ) and Shape of the Plate on the
Perception of the Food Placed on It." Food Quality and
Preference 24(1):205-208. Rozin, P. 1982. "'Taste-Smell Confusions' and the Duality of
the Olfactory Sense." Perception \& Psychophysics the Olfactory Sense." Perception \& Psychophysic
31(4) $397-401$ 31(4):397-401.
Budmin, F.; Cappelli, M. 1983. "Tone-Taste Synesthesia: A Replication." Perceptual and Motor Skills 56:10-118.

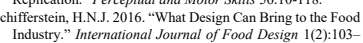
Schifferst
Industry,
134.
Sell $S$.

Sell, S.C. 2014. "Chapter 1: Why Do We Have a Sense of Smell ?" In Chemistry and Sense of Smell. New Jersey, EUA: John Wiley \& Sons, Ltd.
Sell, S.C. 2014. "Chapter 4: The Sense of Smell in Our Lives Sell, S.C. 2014. "Chapter 4: The Sense of Smell in Our Lives
Chemistry and the Sense of Smell." In Chemistry and Sense

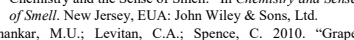
Expectations: The Role of Cognitive Influences in Color-
flavor Interactions." Consciousness and Cognition
19(1):380-390. Spence, C.; Deroy, O. 2013. "On the Shapes of Flavours: A
Review of Four Hypotheses." Theoria et Historia Scientiarum 5:207-238. "Asessing the Shape Symbolism Spence, C.; Ngo, M.K. 2012. "Assessing the Shape Symboliss
of the Taste, Flavour, and Texture of Foods and Beverages." Flavour 1:1-12. Spence, C. 2015. "Just How Much of What We Taste Derive
from the Sense of Smell ?" Flavour 4(30): 1-10. from the Sense of Smell ?" Flavour 4(30): I-10.
Spence, C. 2017. "Enhancing the Experience of Food and Drink via Neuroscience-Inspired Oliacton
Society 12(2):209-221. Spence, C.; Wan, X. 2015. "Beverage Perception and
Consumption: The Influence of the Container on the Perception of the Contents." Food Quality and Preference 39:131-140. Spence, C.; Youssef, J.
the Dominant Sense." Flavour 4(32): 1-14. Evenson, R. 2009. The Psychologgy
England: Oxford University Press.

Stewart, P.C.; Goss, E. 2013. "Plate Shape and Colour Interac Ulloa, A. M.; Roca, J.; Vilaseca, H. 2017 . "From Sensory
Capacities to Sensible Skills: Experimenting with El Celler Capacities to Sensible Skills : Experimenting with El Celler
de Can Roca." Gasstronomica: The Journal of Critical Food Studies 17(2):26-38. Ventanas, S.; Mustonen, S.; Puolanne, E.; Tuorila, H. 2010.
"Odour and Flavour Perception in Flavoured Mode "Odour and Flavour Perception in Flavoured Mode and Serving Temperature." Food Quality and Preference $21(5)$ ):433-462.
Vilanova, M.; Vidal, P.; Cortés, S. 2008. "Effect of the Glass Shape on Flavor Perception Of 'toasted Wine' from Ribeir Vogelzang, M.; Schouwenberg, L. 2008. Eat Love: Foo Concepts. Amsterdam: BIS Publishers.
Wan, X.; Zhou, X.; Woods, A.T.; Spence, C. 2015. "Influence
of the Glassware on the Perception of Alcoholic Drinks." Food Quality and Preference 44:101-110.
Watz, B. 2008. "The Entirety of the Meal: A Designer', Perspective." Journal of Foodservice 19:96-104.
Woortmann, K.A.A. 2004. The Symbolic Meaning of Food Woortmann, K.A.A. 2004. The Symbolic Meaning of Food.
Gastronomy: Courteous and Re-Courteous. Brasilia:
SENAC. Zampollo, F. 2013. Meaningfil Eating: A New Method for Foo

This research was supported in part by La Masia (R\&D department) at El Celler de Can Roca restab rant. This paper was presented on the 19th of October 2017 at the lst International Conference on Food Design and Food Studies: Experiencing Food and DeUniversity of Lisbon and at Estoril Higher Institute for Tourism and Hotel Studies, Estoril.

\subsection{D PROTOTYPES AND TECHNICAL DRAWS VAA}
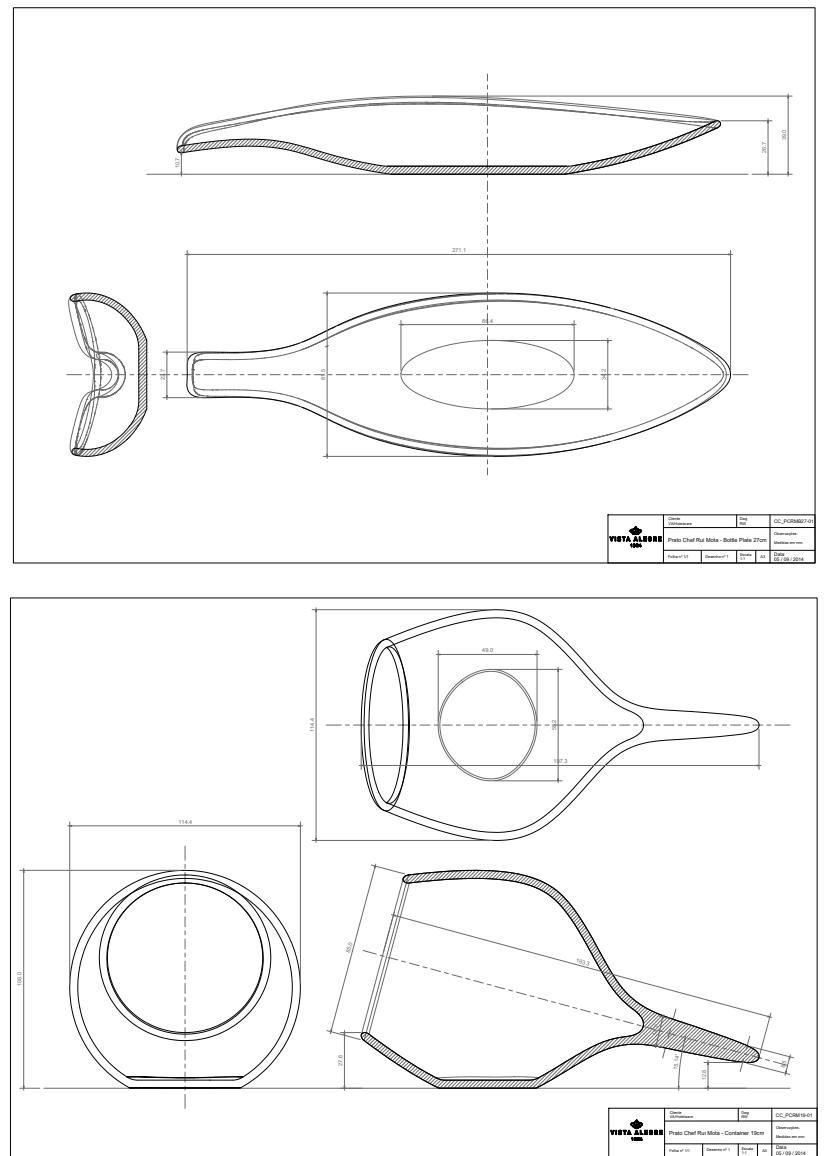